\title{
LIXIVIAÇÃO DE ESPÉCIES QUÚMICAS EM LATOSSOLOS SUCESSIVAMENTE TRATADOS COM BIOSSÓLIDO E DISPONIBILIDADE DE METAIS PESADOS PARA PLANTAS DE MILHO
}

ANA ROSA MARTINS DOS ANJOS

Engenheiro Agrônomo

Orientador: Prof ${ }^{\mathfrak{a}}$. Dr ${ }^{a}$. MARIA EMÍLIA MATTIAZZO-PREZZOTO

Tese apresentada à Escola Superior de Agricultura "Luiz de Queiroz". Universidade de São Paulo: para obtenção do título de Doutor em Agronomia. Área de Concentraçāo: Solos e Nutrição de Plantas.

PIRACICABA

Estado de São Paulo - Brasil

Setembro - 1999 
Dados Internacionais de Catalogação na Publicação (CIP) DIVISĀo DE BIBLIOTECA E DOCUMENTAÇĀO - Campus "Luiz de Queiroz"/USP

Anjos, Ana Rosa Martins dos

Lixiviação de espécies quimicas em latossolos sucessivamente tratados com biossólido e disponibilidade de metais pesados para plantas de milho / Ana Rosa Martins dos Anjos. - - Piracicaba, 1999.

191 p. : il.

Tese (doutorado) - Escola Superior de Agricultura Luiz de Queiroz, 1999.

Bibliografia.

1. Extrator químico 2. Latossolo 3. Lixiviação do solo 4. Metal pesado 5 . Milho 6. Nutrição mineral 7. Poluição ambiental 8. Reciclagem 9. Residuo orgànico 1. Titulo

CDD 633.15 


\title{
A DEUS,
}

pela VIDA, humildemente

\section{OFEREÇO.}

Aos meus pais

\author{
JAYME e LÚCIA, \\ pela formação, incentivo e compreensão em todo decorrer dos \\ estudos, \\ Ao meu noivo e irmãos \\ ÂNGELO, VERA, GISELE e ALEXANDRE, \\ pelo incentivo e compreensão em todo decorrer dos estudos,
}




\section{AGRADECIMENTOS}

Ao curso de Pós-Graduação em Solos e Nutrição de Plantas, pela acolhida e contribuição à formação científica.

Ao Conselho Nacional de Desenvolvimento Científico e Tecnológico (CNPq), pela bolsa de estudo concedida durante o período de fevereiro a junho de 1996.

À Fundação de Amparo à Pesquisa do Estado de São Paulo (FAPESP), pela bolsa de estudo concedida durante o período de julho de 1996 até o ano de 1999.

À Professora Dra. Maria Emília Mattiazzo-Prezotto, pela amizade, incentivo e orientação.

Ao Professor Dr. Francisco Antônio Monteiro, pela receptividade, oportunidade e atenção que se fez presente em todos os momentos.

Aos professores dos Departamentos de Ciências Exatas - Área de Química e de Solos e Nutrição de Plantas da ESALQ/USP, pela amizade e incentivo.

Às secretárias Angélica e Giovana pela gentileza e atenção constantes.

Aos laboratoristas dos Departamentos de Ciências Exatas - Área de Química e de Solos e Nutrição de Plantas da ESALQ/USP pela gentil colaboração.

Aos amigos Rafaela, Sérgio, Paulo Leonel, Francine, Adriana, Tadeu, Fábio, Marcelo, Mafra, Sueli, Oscarlina, pela amizade sincera e apoio em todos momentos.

Aos colegas do curso de Solos e Nutrição de Plantas que tornaram esta fase de minha vida mais agradável. 
À Mônica Abreu, Jussara e Cleide Abreu do Instituto Agronômico de Campinas pela boa vontade com que sempre me atenderam.

À bibliotecária Eliana, pelas correções das Referências Bibliográficas.

Finalmente, a todos aqueles que direta ou indiretamente colaboraram para realização deste trabalho. 


\section{SUMÁRIO}

Página

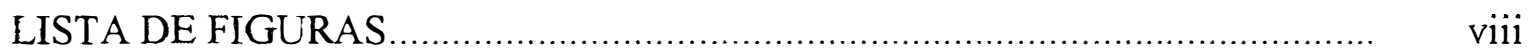

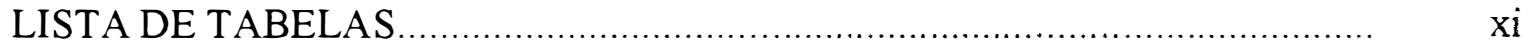

RESUMO

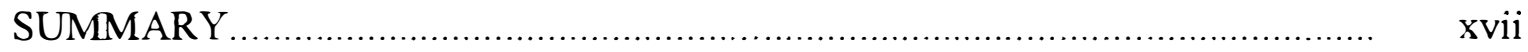

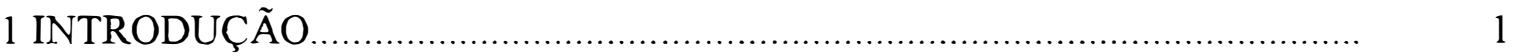

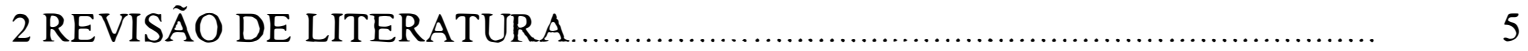

2.1 Vantagens do uso agrícola de biossólidos.................................................... 5

2.2 Riscos ambientais da reciclagem agrícola de biossólidos.............................. 12

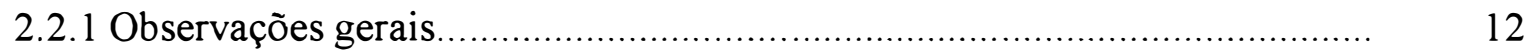

2.2.2 Lixiviação de espécies químicas em solos tratados com biossólido.............. 13

2.2.2.1 Lixiviação de $\mathrm{K}^{+}, \mathrm{Ca}^{2+}, \mathrm{Mg}^{2+}$ e metais pesados...................................... 13

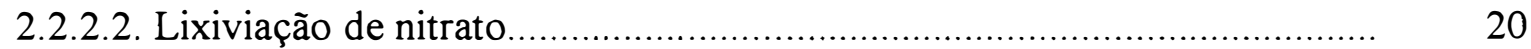

2.2.3 Fitodisponibilidade de metais pesados em solos tratados com

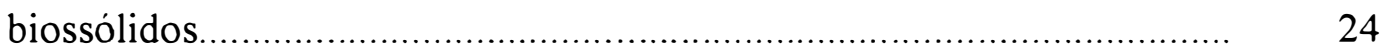

2.2.3.1 Fatores que governam a disponibilidade de metais pesados às plantas.

2.2.3.2 Utilização de extratores para a avaliação da fitodisponibilidade de metais pesados em solos tratados com biossólidos................................. 33

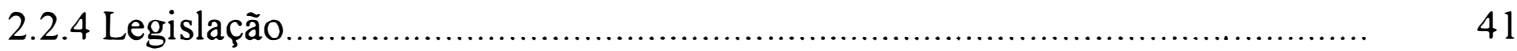

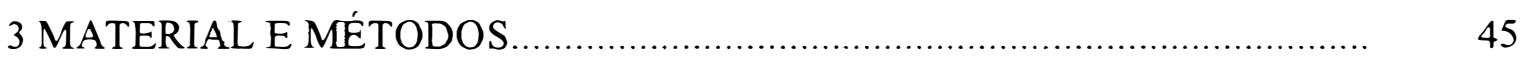

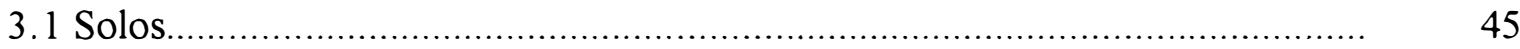

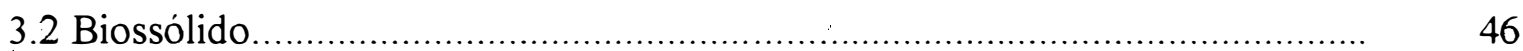

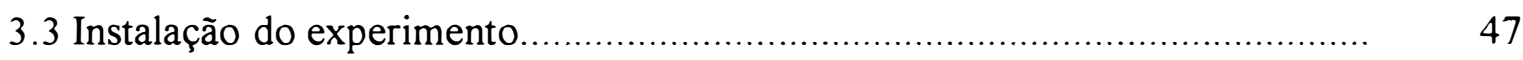

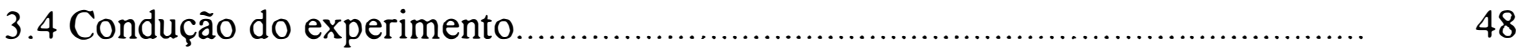

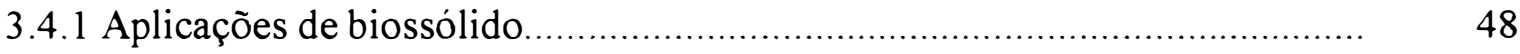

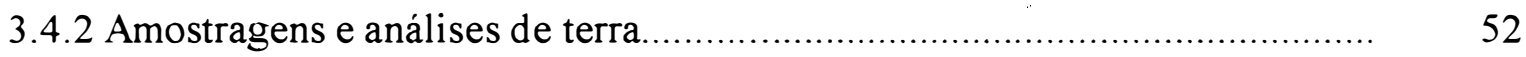

3.4.3 Lixiviados coletados e análises realizadas.................................................. 54 
3.4.4 Fitodisponibilidade de metais no solo e avaliação de métodos de extração.. 56

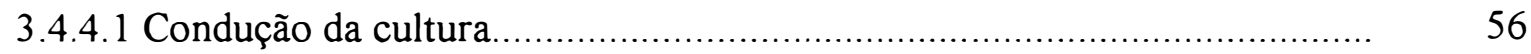

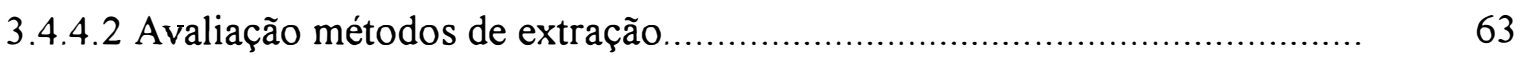

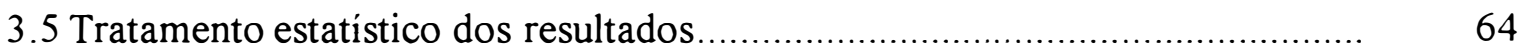

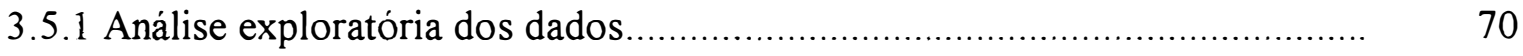

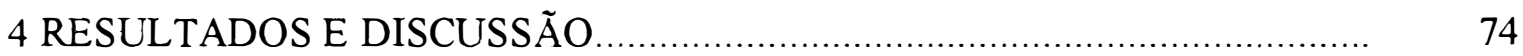

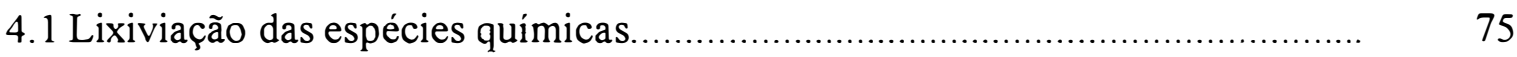

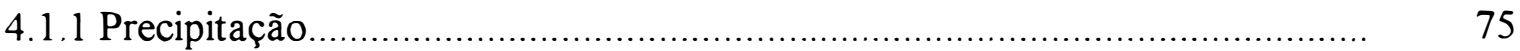

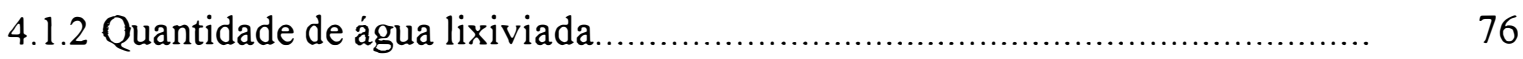

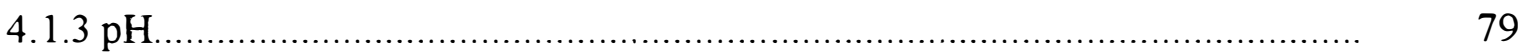

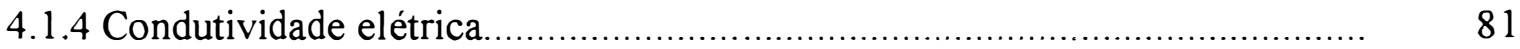

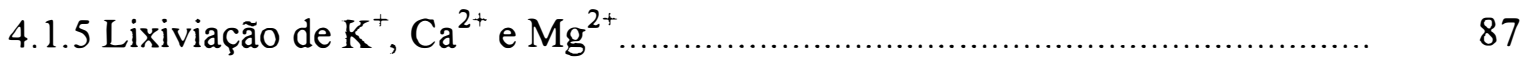

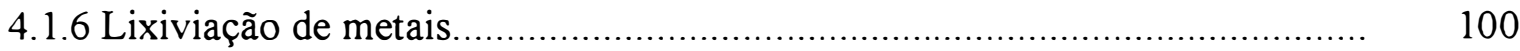

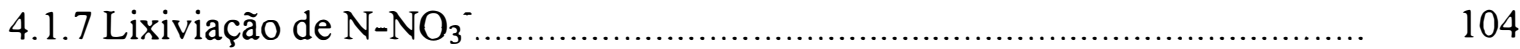

4.2 Metodos de extração e fitodisponibilidade de metais.................................. 109

4.2.1 Avaliação do teor total e disponínel de metais através de extratores............ 109

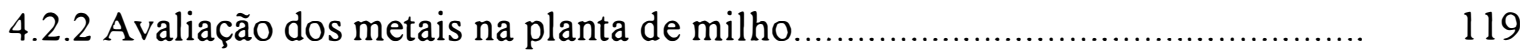

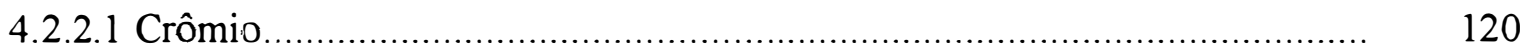

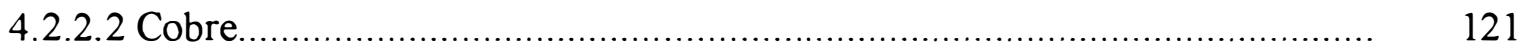

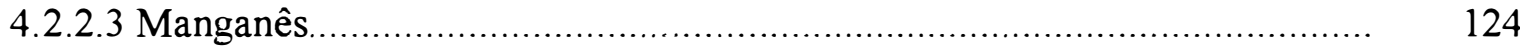

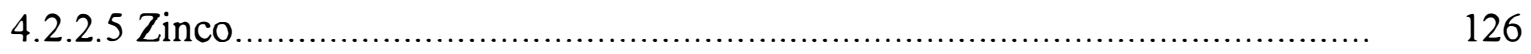

4.2.3 Correlações entre os teores de metais removidos dos solos por diferentes métodos de extração e os observados nas diversas partes da planta........... 130

4.3 Influência da aplicação de biossólido em alguns caracteres da planta de milho

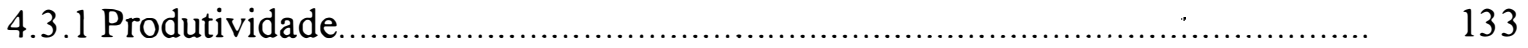

4.3.1.1 Correlação: Produtividade x Metais na plantas................................. 137

4.3.2 Produção de matéria seca total e $N$ na planta....................................... 139

4.3.3 Crescimento das plantas: diâmetro do colmo e altura.......................... 141

5 APRECIAÇÃO GERAL DOS RESULTADOS OBTIDOS ......................... 143 


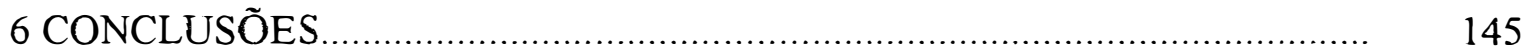

REFERÊNCIAS BIBLIOGRÁFICAS ................................................... 146

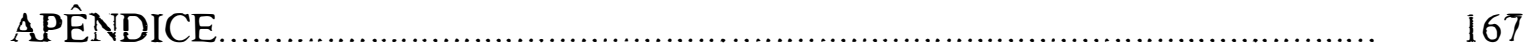




\section{LISTA DE FIGURAS}

Página

1 Aspecto geral do experimento por ocasião da primeira aplicação de biossólido, antes da incorporação deste material a $20 \mathrm{~cm}$............................... 49

2 Aspecto do galão de água que recebia o lixiviado........................................... 56

3 Sintoma de deficiência de $\mathrm{P}$ no tratamento LV+lodo........................................ 59

4 Sintoma de deficiência de N no tratamento LR+lodo..................................... 60

5 Aspecto geral da cultura de milho, com as plantas no estádio 3 (8 folhas)......... 61

6 Comparação dos valores pluviométricos observados durante o monitoramento da água lixiviada e o desenvolvimento da cultura de millho com os valores pluviométricos normais da região de Piracicaba............................................ 75

7 Variações na quantidade de água lixiviada em função das aplicações de

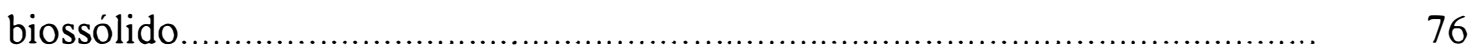

8 Variações na quantidade de água lixiviada em função das aplicações de

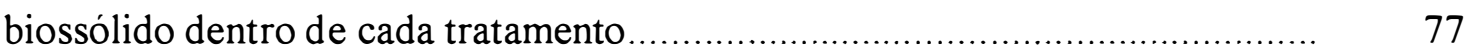

9 Variações no pH do solo em função das aplicações de biossólido..................... 79

10 Variações no $\mathrm{pH}$ da água lixiviada em função das aplicações de biossólido dentro de cada tratamento.

11 Variações na condutividade elétrica da água lixiviada (a) e do solo (b) em função das aplicações de biossólido.

12 Variações na condutividade elétrica da água lixiviada em função das aplicações de biossólido dentro de cada tratamento.

13 Variações na condutividade elétrica do solo em função das aplicações de biossólido dentro de cada tratamento.

14 Variações na quantidade de $\mathrm{K}^{+}$no lixiviado (a) e no teor de $\mathrm{K}^{+}$no solo (b) em função das aplicações de biossólido.

15 Variações na quantidade de $\mathrm{Ca}^{2+}$ no lixiviado (a) e no teor de $\mathrm{Ca}^{2+}$ no solo (b) em função das aplicações de biossólido. 
16 Variações na quantidade de $\mathrm{Mg}^{2+}$ no lixiviado (a) e no teor de $\mathrm{Mg}^{2+}$ no solo (b) em função das aplicações de biossólido.

17 Variações no teor de $\mathrm{Ca}^{2+}$ no solo em funç̧ão das aplicações de biossólido dentro de cada tratamento

18 Variações no teor de $\mathrm{Mg}^{2+}$ no solo em função das aplicações de biossólido dentro de cada tratamento

19 Variações na quantidade de $\mathrm{K}^{+}$no lixiviado em função das aplicações de biossólido dentro de cada tratamento

20 Variações na quantidade de $\mathrm{Ca}^{2+}$ no lixiviado em função das aplicações de biossólido dentro de cada tratamento

21 Variações na quantidade de $\mathrm{Mg}^{2+}$ no lixiviado em função das aplicações de biossólido dentro de cada tratamento

22 Variações na quantidade de $\mathrm{N}_{-} \mathrm{NO}_{3}{ }^{-}$no lixiviado em função das aplicações de biossólido.

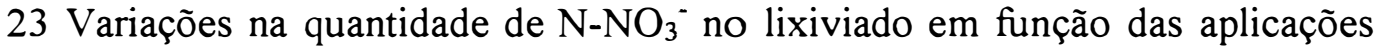
de biossólido dentro de cada tratamento.

24 Variações nos teores médios de $\mathrm{Cd}$ removidos por diversos métodos de extração em função das aplicações de biossólido

25 Variações nos teores médios de $\mathrm{Cu}$ (a), Mn (b) e $\mathrm{Zn}$ (c) removidos por diversos métodos de extração em função das aplicações de biossólido

26 Variações nos teores médios de $\mathrm{Cr}$ (a) e $\mathrm{Ni}$ (b) removidos por diversos métodos de extração em função das aplicações de biossólido

27 Variações no teor (a) e na quantidade absorvida (b) de $\mathrm{Cr}$ encontrados no sabugo das plantas de milho em função das aplicações de biossólido

28 Variações no teor (a) e na quantidade absorvida (b) de $\mathrm{Cu}$ encontrados nas diversas partes das plantas de milho em função das aplicações de biossólido

29 Variações no teor (a) e na quantidade absorvida (b) de Mn encontrados nas diversas partes das plantas de milho em função das aplicações de biossólido 
30 Variações no teor (a) e na quantidade absorvida (b) de $\mathrm{Zn}$ encontrados nas diversas partes das plantas de milho em função das aplicações de biossólido

31 Aspecto geral das espigas produzidas em cada tratamento e em cada bloco.... 135

32 Variações na produtividade das plantas de milho em função das aplicações 136 de biossólido.

33 Variações na produção de matéria seca total das plantas de milho em função das aplicações de biossólido.

34 Variações no teor (a) e na quantidade absorvida (b) de $\mathrm{N}$ encontrados na folha diagnose (FD) e nas folhas ao final do ciclo (FF) das plantas de milho em função das aplicações de biossólido.

35 Crescimento do diâmetro do colmo (a) e a altura (b) durante o ciclo vegetativo do milho. 


\section{LISTA DE TABELAS}

Página

1 Métodos de extração utilizados para remoção de metais pesados em solos tratados com biossólido

2 Comparação dos limites de qualidade dos biossólidos estabelecidos pela USEPA 40 CFR Parte 503 e pela Diretriz da Comunidade Européia 86/278/EEC. Valores expressos em $\mathrm{mg} \mathrm{kg}^{-1}$ de matéria seca.

3 Comparação dos limites de aplicação anual de biossólidos e de padrão de qualidade do solo estabelecidos pela USEPA 40 CRF Parte 503 e pela Diretriz da Comunidade Européia 86/278/EEC

4 Características químicas das terras utilizadas na instalação do experimento.

5 Granulometria e teores totais de óxidos de silício, ferro e alumínio das terras utilizadas na instalação do experimento

6 Caracterização química do biossólido utilizado nas cinco aplicações. Valores médios de três repetições.

7 Quantidade de biossólido adicionado às amostras de terra contidas nas caixas.

8 Quantidades de $\mathrm{N}, \mathrm{P}, \mathrm{K}, \mathrm{Ca}$ e $\mathrm{Mg}$ incorporadas às amostras de terra pelas aplicações de biossólido

9 Quantidades de metais incorporadas às amostras de terra até a profundidade de $20 \mathrm{~cm}$ pelas aplicações de biossólido.

10 Parâmetros de avaliação da fertilidade da terra e condutividade elétrica dos tratamentos 47 dias após a última aplicação de biossólido. Valores médios de quatro repetições

11 Análise de micronutrientes nas terras antes do cultivo de milho. Valores médios de quatro repetições.

12 Período de coleta dos lixiviados durante a aplicação de biossólido

13 Características físico-químicas do calcário calcinado aplicado no experimento 
14 Adubação mineral realizada na semeadura do milho....................................... 58

15 Adubação mineral de cobertura da cultura do milho......................................... 60

16 Período de realização dos tratos culturais da cultura do m tho .......................... 63

17 Esquema de análise da variância e teste F para delineamento em blocos com

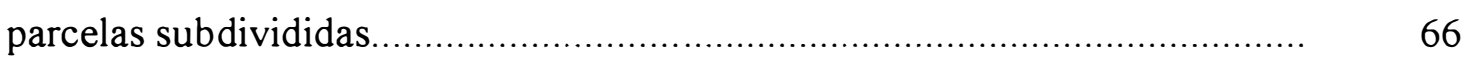

18 Esquema do desdobramento dos graus de liberdade de tratamentos em contrastes ortogonais e teste $\mathrm{F}$.

19 Esquema de análise da variância e teste F para delineamento em blocos com fatorial

20 Esquema de análise da variância e teste $\mathrm{F}$ para o delineamento em blocos ao acaso...

21 Coeficientes de correlação e respectivas significâncias estatísticas, pelo teste $\mathrm{t}$, entre as variáveis condutividade elétrica, $\mathrm{pH}, \mathrm{K}^{-}, \mathrm{Ca}^{2+}, \mathrm{Mg}^{2+}$ encontradas no solo e na água lixiviada, levando em consideração todos os tratamentos....

22 Coeficientes de correlação e respectivas significâncias estatísticas, pelo teste $\mathrm{t}$, entre as variáveis condutividade elétrica, $\mathrm{pH}, \mathrm{K}^{*}, \mathrm{Ca}^{2+}, \mathrm{Mg}^{2+}$ encontradas no solo e na água lixiviada, referentes ao tratamento $\mathrm{LV}+$ lodo e $\mathrm{LR}+$ lodo.....

23 Quantidade de $\mathrm{K}^{+}, \mathrm{Ca}^{2+}{\mathrm{e} \mathrm{Mg}^{2+} \text { (mg volume total lixiviado }}^{-1}$ ) nos tratamentos com biossólido e percentagem de lixiviação de $\mathrm{K}^{-}, \mathrm{Ca}^{2+} \mathrm{e} \mathrm{Mg}^{2+}$ em função da quantidade total destes elementos presentes nas amostras de terra..............

24 Quantidade de $\mathrm{N}^{-\mathrm{NO}_{3}}{ }^{-}$removida pela percolação da água da chuva. Valores médios de quatro repetições, expresso em $\mathrm{mg} \mathrm{L}^{-1}$ e em $\mathrm{mg}$ volume total lixiviado ${ }^{-1}$......

25 Teores médios de $\mathrm{Cr}, \mathrm{Cu}^{2+}, \mathrm{Mn}^{2+}, \mathrm{Ni}^{2+}$ e $\mathrm{Zn}^{2+}$ extraídos por soluções de $\mathrm{HCl}$ $0,1 \mathrm{~mol} \mathrm{~L}^{-1}$, Mehlich 3, DTPA pH 7,3 e água régia observados dentro de cada tratamento..

26 Coeficientes de correlação e respectivas significâncias estatísticas, pelo teste $\mathrm{t}$, entre os teores de $\mathrm{Cr}, \mathrm{Cu}, \mathrm{Mn}$ e $\mathrm{Zn}$ removidos por diversos extratores, teor total e os ocorrentes nas diversas partes da planta. 
27 Coeficientes de correlação entre produtividade e teores (ou quantidades absorvidas) de $\mathrm{N}, \mathrm{Cr}, \mathrm{Cu}, \mathrm{Mn}$ e $\mathrm{Zn}$ nas diversas partes da planta, envolvendo todos os tratamentos

28 Coeficientes de correlação entre produtividade e teores (ou quantidades absorvidas) de $\mathrm{N}, \mathrm{Cr}, \mathrm{Cu}, \mathrm{Mn}$ e $\mathrm{Zn}$ nas diversas partes da planta, nos tratamentos LV+lodo

29 Coeficientes de correlação entre produtividade e teores (ou quantidades absorvidas) de $\mathrm{N}, \mathrm{Cr}, \mathrm{Cu}, \mathrm{Mn}$ e $\mathrm{Zn}$ nas diversas partes da planta, referentes aos tratamentos $\mathrm{LR}+$ lodo 


\title{
LIXIVIAÇÃO DE ESPÉCIES QUÍMICAS EM LATOSSOLOS SUCESSIVAMENTE TRATADOS COM BIOSSÓLIDO E DISPONIBILIDADE DE METAIS PESADOS PARA PLANTAS DE MILHO
}

\author{
Autora: ANA ROSA MARTINS DOS ANJOS \\ Orientadora: Prof ${ }^{\mathrm{a}}$. Dr ${ }^{\mathrm{a}}$. MARIA EMIILIA MATTIAZZO-PREZOTTO
}

\section{RESUMO}

A lixiviação de $\mathrm{K}^{+}, \mathrm{Ca}^{2+}, \mathrm{Mg}^{2+}$, metais pesados e nitratos, a capacidade de acumulação de metais pesados e sua disponibilidade para plantas de milho, em solos sucessivamente tratados com biossólido, foi avaliada em um experimento em vasos com capacidade para $0,500 \mathrm{~m}^{3}$ de terra, conduzido a céu aberto, segundo delineamento em blocos ao acaso, com quatro repetições.

Os solos foram Latossolo Vermelho Amarelo distrófico textura média (LV) e Latossolo Roxo distrófico textura argilosa (LR), aos quais, a cada dois meses, foi feita aplicação de biossólido numa quantidade média de $78 \mathrm{Mg} \mathrm{ha}^{-1}$ base seca, totalizando, nas cinco aplicações feitas durante um período de 12 meses, $388 \mathrm{Mg} \mathrm{ha}^{-1}$ de biossólido. Os tratamentos testemunha, nessa etapa de estudos, eram constituídos unicamente pelo solo. As aplicações de biossólido foram sempre precedidas de amostragem de solo para análise e toda a água drenada através dos vasos, durante o período, era monitorada e analisada.

Ao final das aplicações de biossólido foi avaliada a disponibilidade de metais 
presentes no solo para plantas de milho (Zea mays) e feita a correlação entre teor nas plantas e teor disponível no solo avaliado pelos extratores $\mathrm{HCl} \mathrm{0,1} \mathrm{mol} \mathrm{L}^{-1}$, Mehlich 3, DTPA $0,005 \mathrm{~mol} \mathrm{~L}^{-1} \mathrm{pH} 7,3$. Os teores totais de metais presentes no solo foram determinados por extração com água régia em microondas.

Durante o desenvolvimento das plantas foram feitas medidas semanais de altura e diâmetro do colmo. Quando as plantas apresentaram um pendoamento de $50 \%$ foi feita amostragem foliar. As plantas foram colhidas quando atingiram o ponto de maturidade fisiológica, sendo separadas em pendão, folhas, colmo, bainha, grãos, sabugo e palha que envolve a espiga. Todo o material vegetal obtido foi analisado.

Os resultados obtidos permitiram concluir que a realização de freqüentes aplicações do biossólido em taxas de $78 \mathrm{Mg} \mathrm{ha}^{-1}$, promoveu o aumento da condutividade elétrica dos solos, principalmente o $\mathrm{LR}$, e maior lixiviação de $\mathrm{N}-\mathrm{NO}_{3}^{-}, \mathrm{K}^{+}, \mathrm{Mg}^{2+}$ e $\mathrm{Ca}^{2+}$. As quantidades de metais pesados presentes no lixiviado estiveram abaixo do limite de determinação do método analítico utilizado.

Apesar das sucessivas aplicações de biossólido terem promovido elevação na produção de matéria seca das plantas, esse aumento não se traduziu em elevação de produtividade, quando comparada ao tratamento testemunha que recebeu adubação convencional. As diferenças de produtividade observadas entre os solos tratados com biossólido provavelmente possa ser explicada pelo maior acúmulo de sais no LR.

Os metais $\mathrm{Cd}, \mathrm{Cr}$, $\mathrm{Ni}$ e $\mathrm{Pb}$ não foram detectados nas várias partes analisadas das plantas de milho, porém a adição de $\mathrm{Cu}$ e $\mathrm{Zn}$ via biossólido contribuiu para aumentar os teores desses elementos, com exceção do grão e sabugo.

Dentre os extratores utilizados, o Mehlich 3 foi o mais eficiente na previsão da disponibilidade de $\mathrm{Cu}$ e $\mathrm{Zn}$ para plantas de milho.

A possibilidade de lixiviação de $\mathrm{N}_{-} \mathrm{NO}_{3}{ }^{-}$para o lençol freático faz com que a taxa e a freqüência de aplicação de biossólidos em áreas agrícolas seja condicionada por esse elemento.

Embora não tenha sido verificada a lixiviação dos metais $\mathrm{Cd}, \mathrm{Cr}, \mathrm{Cu}, \mathrm{Mn}, \mathrm{Ni}, \mathrm{Pb}$ e $\mathrm{Zn}$ e a passagem para a cadeia alimentar de $\mathrm{Cd}, \mathrm{Cr}$, $\mathrm{Ni}$ e $\mathrm{Pb}$, o manejo de biossólidos em regiões de clima tropical deve levar em consideração o poder diferenciado de 
acumulação de metais dos solos e a possibilidade de liberação dos mesmos em função de variações nas características químicas dos solos. 


\title{
AVAILABILITY OF HEAVY METALS TO CORN PLANTS AND THE LEACHING OF CHEMICAL SPECIES IN ACID SOIL CONTINUOUSLY AMENDED WITH BIOSOLIDS
}

\author{
Author: ANA ROSA MARTINS DOS ANJOS \\ Adviser: Prof Dra ${ }^{a}$. MARIA EMÍLIA MATTIAZZO-PREZOTTO
}

\section{SUMMARY}

In this paper data are presented from a pot experiment using biosolid-amended soil for evaluation: 1) the leaching of $\mathrm{K}^{+}, \mathrm{Ca}^{2+}, \mathrm{Mg}^{2+}$, heavy metals and nitrates; 2) the accumulation capacity of soils for heavy metals and 3) bioavailability of these heavy metals to corn plants. Pots used in the experiment had a $0.5 \mathrm{~m}^{3}$ capacity and were filled with soils; Rhodic Hapludox (clayey) and Typic Hapludox (coarse loamy). The statistic design adopeted was a randomized block design with four replications and four treatments.

Biosolids were applied to soils every two months in amounts corresponding to $78 \mathrm{Mg} \mathrm{ha}^{-1}$ (dry weight basis), during a 12 months period totalizing 5 additions for a total of $388 \mathrm{Mg} \mathrm{ha}^{-1}$. Control treatments consisted of soil only. Soil sampling was made before biosolid application. Leachate was collected, sampled and analyzed. Rainfall during this period was measured. 
Heavy metal availability to com plants was evaluated after the final addition of biosolids. Correlations between level of metal present in plant parts and available level in soil estimated using various extractants: $0.1 \mathrm{~mol} \mathrm{~L}^{-1} \mathrm{HCl}$; Mehlich 3; DTPA $5 \mathrm{mmol} \mathrm{L}^{-1}$ $\mathrm{pH}=7.3$ were made. Total metal level in soil was analyzed by acqua regia digestion in a microwave.

During plant growth, measurements of plant high and stem diameter were made weekly. Leaf sampling was made when plants were at 50\% flowering. At harvesting the plants parts were separated and analyzed. The results for flowers, leaves, stem, sheath, grain, com cob and straw were presented separately.

From the results, we concluded that the rate and frequency of biosolid application $\left(78 \mathrm{Mg} \mathrm{ha}^{-1}\right)$ caused an increase in soil electric conductivity, but the values were not close to those for saline soil limits. There was also an increase in nitrate, $\mathrm{K}^{+}, \mathrm{Mg}^{2+}$ and $\mathrm{Ca}^{2+}$ leaching. Presence of heavy metals was not observed in the leachate. The possibility of $\mathrm{N}$ $\mathrm{NO}_{3}^{-}$leaching to groundwater makes the biosolids application to soil dependent of the biosolids content of $\mathrm{N}$.

Dry matter production was higher in treatments with biosolids, but this increase did not correspond to an increase in com productivity compared to the control that was fertilized with a mineral formula. Differences between treatments with biosolids as a function of soil type was also observed. Probably this was due to the high salt concentration in the Typic Hapludox soil

Concentration of $\mathrm{Cd}, \mathrm{Cr}, \mathrm{Ni}$, and $\mathrm{Pb}$ in plant parts were below detection, but $\mathrm{Cu}$ and $\mathrm{Zn}$ addition by biosolids increased the level in plant parts with the exception of grain and cob. Mehlich 3 was the most effective extractant for the determination of $\mathrm{Cu}$ and $\mathrm{Zn}$ availability to com plants.

Althought no $\mathrm{Cd}, \mathrm{Cr}, \mathrm{Cu}, \mathrm{Ni}, \mathrm{Pb}$ and $\mathrm{Zn}$ leaching was observed nor the transfer of $\mathrm{Cd}, \mathrm{Cr}, \mathrm{Ni}$ and $\mathrm{Pb}$ to the food chain, care must be taken about changes in soil properties that could cause movement of those metals. 


\section{INTRODUÇÃo}

No Brasil, a urbanização acelerada gerou um déficit na infra-estrutura de serviços urbanos, cuja manifestação ambiental é a carência de saneamento básico. Verifica-se que apenas $35 \%$ da população brasileira dispõe de coleta de esgoto, sendo que a maioria dos recursos investidos em saneamento básico concentram-se na região sudeste, e apenas $10 \%$ do esgoto coletado tem tratamento final adequado, indicando que perto de dez bilhões de litros de esgoto in natura são lançados por dia ao solo ou em cursos d'água (Brasil, 1991; Seminário sobre gerenciamento de biossólidos do Mercosul, 1998). Nas regiões periféricas dos centros urbanos, as matérias fecais são depositadas em precários postos sépticos, praticamente a céu aberto. Isto evidencia um alto grau de degradação do meio ambiente e o estado de higiene da população afetada.

Nos grandes centros urbanos o tratamento das águas residuárias gera outro problema ambiental a ser solucionado, é a disposição final do lodo de esgoto gerado, também denominado biossólido. Este resíduo pode ser oriundo do tratamento das águas residuárias de origem doméstica, industrial ou de uma mistura de ambas. Atualmente sua produção é incipiente na maioria das cidades brasileiras, porém tenderá a aumentar em função do crescimento populacional e industrial, bem como do aumento da conscientização em relação à necessidade de preservação e despoluição ambiental.

A disposição final adequada deste resíduo é uma etapa problemática no processo operacional de uma estação de tratamento de esgoto, pois seu planejamento tem sido negligenciado e apresenta um custo que pode alcançar $40 \%$ do orçamento operacional de um sistema de tratamento (Seminário sobre gerenciamento de biossólidos do Mercosul, 1998).

Normalmente o biossólido é descartado em aterros sanitários exclusivos, 
entretanto há outras opções, dentre elas pode-se citar as fazendas de lodo, o descarte em oceanos, a incineração e a reciclagem agrícola. Opções como a incineração e disposição em aterros sanitários requerem tecnologia sofisticada e podem apresentar alto custo por tonelada tratada (Carvalho \& Barral, 1981; Andreoli \& Pegorini, 1998).

O uso agrícola de biossólidos tem se mostrado, dentro do panorama mundial, como uma solução adequada do ponto de vista técnico, econômico e ambiental por viabilizar a reciclagem de nutrientes, promover melhorias fisicas, químicas, biológicas e principalmente por representar uma solução para minimizar o problema da disposição das grandes quantidades de lodo de esgoto gerado. Estima-se que 54\% de 6,4 milhões de $\mathrm{Mg}$ ano $^{-1}$ de biossólido produzido nos E.U.A. são aplicados na agricultura. $\mathrm{Na}$ Alemanha, França e Grã-Bretanha esse valor atinge, respectivamente, 32\% de 2,5 milhões de $\mathrm{Mg}$ ano ${ }^{-1}, 60 \%$ de 0,85 milhões de $\mathrm{Mg}$ ano $^{-1}$ e $55 \%$ de 1,08 milhões de Mg ano ${ }^{-1}$ (Rogalla, 1998).

Os principais riscos ambientais relacionados ao uso agrícola de biossólidos são representados pelo seu conteúdo de elementos traços (metais e micropoluentes orgânicos) e pelos riscos de poluição das águas superficiais e subterrâneas causados por substâncias orgânicas e pelo nitrato (Andreoli et al. 1997).

Diversos autores têm chamado a atenção para as limitações quanto ao uso agrícola de biossólidos devido a presença de metais pesados, entre eles Logan \& Chaney (1983), Chang et al. (1984), Kim et al. (1988), Jing \& Logan (1992), Chang et al. (1997) e Raij (1998). A preocupação de que a aplicação de biossólidos em áreas agrícolas possa introduzir metais pesados, tais como $\mathrm{Cd}, \mathrm{Cr}$ ou $\mathrm{Hg}$, dentro da cadeia alimentar, não depende apenas das características do biossólido e das doses aplicadas, mas também das características químicas e mineralógicas dos solos, nos quais o biossólido é aplicado, envolvendo inclusive as condições climáticas locais e a espécie de planta considerada (Hue et al., 1988; Kim et al., 1988).

No Brasil, há poucos trabalhos estudando o problema de metais adicionados a solos via resíduos orgânicos. Os trabalhos existentes limitam-se geralmente a constatar a elevação dos teores de metais pesados no solo ou na planta ao se adicionar doses crescentes de um determinado resíduo e comparar tais observações com os limites 
máximos permitidos da legislação americana ou européia. No Estado do Paraná os limites para poluentes no biossólido segue a orientação européia que é mais restritiva, enquanto São Paulo tende para a norte-americana, devido a falta de uma legislação nacional.

Em 1993, a legislação americana aumentou os limites de tolerância para teores de metais pesados presentes no biossólido e desconsiderou a avaliação da CTC do solo, que era exigida na legislação anterior. Wallace \& Wallace (1994) e McBride (1995) criticaram os niveis recomendados afirmando que a adsorção de metais nos solos não é um fato permanente e estes podem vir a ser liberados a longo prazo. Nas regiões tropicais os solos se caracterizam por serem, na sua grande maioria, ácidos, de baixa CTC e baixo teor de matéria orgânica diferindo muito dos solos de regiões temperadas o que faz com que seja perigosa a extrapolação das quantidades de metais possiveis de serem adicionados aos solos.

A primeira tentativa de se estabelecer quantidades máximas de metais possiveis de serem aplicados em solos, no Brasil, foi realizada por Mattiazzo-Prezotto (1994), aplicando os metais, sob a forma de sais, que é a condição de maior solubilidade de metais, em solos com diferentes conteúdos de argila e teores de óxido de ferro e alumínio, entretanto, conforme salientado pelos autores, esse trabalho foi uma primeira aproximação requerendo mais estudos do comportamento de metais pesados em solos tratados com resíduos orgânicos, mais especificamente com biossólidos, com vistas a reunir subsídios para a definição de critérios de adição deste resíduo ao solo.

Diante do enfoque apresentado, formulou-se a hipótese: se repetidas aplicações de biossólidos em solos de diferentes classes texturais e teores de óxidos promoverem maior disponibilidade de espécies químicas presentes, como nitrato e metais pesados, a ponto de ocorrer contaminação do lençol freático, ou mesmo de passagem para a cadeia trófica planta-animal-homem, então poderá se estabelecer critérios para a adição deste resíduo nestes solos.

Tendo em vista a hipótese formulada, os objetivos deste trabalho foram: verificar a lixiviação de $\mathrm{K}, \mathrm{Ca}, \mathrm{Mg}$, metais pesados e nitrato em dois solos com diferentes classes texturais e teores de óxidos, repetidamente tratados com biossólidos; avaliar a 
capacidade de acumulação e a fitodisponibilidade de metais pesados, usando como planta teste o milho; estabelecer correlações entre as quantidades removidas pelo uso de extratores químicos e as quantidades fitodisponíveis de metais. 


\section{REVISÃO DE LITERATURA}

Ao se optar pela reciclagem agrícola dos biossólidos é necessário que se leve em conta os aspectos relativos aos beneficios decorrentes de sua aplicação ao solo, tais como elevação do pH, aumento da CTC, adição de nutrientes, melhoria das propriedades físicas e aumento da atividade biológica, bem como os aspectos que dizem respeito à presença de metais pesados, salinidade, presença de substâncias orgânicas tóxicas e de organismos patogênicos.

Nesta revisão é apresentada uma breve discussão sobre a reciclagem agrícola de biossólidos e os riscos ambientais que podem ocorrer com esta prática, principalmente no que diz respeito a lixiviação de espécies químicas, a fitodisponibilidade de metais pesados e a sua avaliação por meio de extratores.

\subsection{Vantagens do uso agrícola de biossólidos}

Visando distanciar o lodo adequadamente tratado e em condições de ser utilizado na agricultura, da imagem do material fecal que o originou, criou-se no final da década passada nos Estados Unidos o termo biossólidos. Esta nova denominação objetiva vencer o preconceito, atraindo os mais reticentes a conhecerem o potencial agrícola do lodo de esgoto tratado (Luduvice, 1998).

O termo "biossólidos" tem sido recomendado pela Water Environment Federation (WEF) para designar o lodo tratado ou beneficiado de estações de tratamento de esgotos municipais. Segundo o mesmo órgão, o termo "lodo" deve ser reservado para o lodo bruto, primário ou secundário, ainda não submetido a nenhum processo de 
estabilização biológica (Bidone, 1998).

A reciclagem de biossólidos na agricultura é, segundo Luduvice (1998), a melhor alternativa de disposição final deste material quando este atende aos requisitos necessários com relação a concentração de metais pesados e patógenos. Esta é a principal rota de disposição de biossólido na Comunidade Européia e deverá acontecer o mesmo entre os países do Mercosul.

Raij (1998) também ressalta que a reciclagem agrícola de biossólidos na agricultura vem se impondo em países mais desenvolvidos como a melhor alternativa para a disposição prática desses materiais, considerando que outras alternativas são menos vantajosas do ponto de vista econômico ou ambiental.

A alternativa da reciclagem agrícola tem o grande beneficio de transformar esse resíduo em um importante insumo agrícola que fornece matéria orgânica e nutrientes ao solo, promove melhorias fisicas, especialmente na estruturação do solo. Além de trazer vantagens indiretas ao homem e meio ambiente, tais como redução dos efeitos adversos à saúde causados pela incineração e diminuição na dependência de fertilizantes químicos. Podendo ainda, num sentido mais amplo, influenciar as condições da biosfera pela sua integração com políticas globais referentes à dinâmica do carbono atmosférico (Andreoli \& Pegorini, 1998).

Diversos autores têm feito referências afirmando que a aplicação de biossólido na agricultura, como fertilizante, traz uma série de beneficios, dentre os quais destacam-se: fonte de nutrientes ( $\mathrm{N}, \mathrm{P}, \mathrm{Ca}, \mathrm{Mg}$ e $\mathrm{Zn}$ ) para as culturas; aumento no teor de matéria orgânica, CTC, C-orgânico e do pH do solo; diminuição no alumínio trocável do solo; melhoria na estrutura do solo; aumento da produção de matéria seca e da produtividade das culturas (Bettiol et al., 1983; Berton et al., 1989; Marques et al., 1991; Melo et al., 1994; Barretto, 1995; Silva, 1995; Biscaia \& Miranda, 1996; Lourenço et al., 1996; Souza et al., 1998).

Artiola (1998), além de destacar melhorias na fertilidade e nas propriedades físicas do solo, destaca também melhorias nas propriedades biológicas do solo com a utilização de biossólidos em áreas agrícolas. Segundo o autor também há um outro aspecto positivo que diz respeito a fração de $\mathrm{N}$ orgânico do biossólido. Esta fração atua 
como um fertilizante que libera $\mathrm{N}$ lentamente. Isto ocorre porque as taxas de mineralização ( $\mathrm{N}$ orgânico $\rightarrow \mathrm{NH}_{4}$ ) são muito menores que as taxas de nitrificação $(\mathrm{N}$ $\mathrm{NH}_{4}{ }^{+} \rightarrow \mathrm{N}^{-} \mathrm{NO}_{3}{ }^{-}$). Desta forma, se o biossólido contem $50 \%$ de $\mathrm{N}$ orgânico e $50 \%$ de $\mathrm{N}$ inorgânico, as formas inorgânicas $\left(\mathrm{N}^{-} \mathrm{NH}_{4}{ }^{+}\right.$e $\left.\mathrm{N}_{-} \mathrm{NO}_{3}{ }^{-}\right)$estarão disponíveis às plantas dentro de poucos dias após aplicação, enquanto que as formas orgânicas serão lentamente disponíveis, por volta de alguns meses e mesmo anos.

Muitas pesquisas foram conduzidas sobre os efeitos benéficos dos biossólidos na fertilidade do solo, absorção de nutrientes e produtividade das culturas.

Estudando o efeito de biossólido sobre algumas propriedades fisicas e químicas, Epstein et al. (1976) verificaram que a aplicação de biossólido aumentou a disponibilidade de $\mathrm{P}$ durante os dois anos de estudo, além de aumentar o conteúdo e a retenção de água em um solo franco siltoso.

Utilizando o biossólido como fertilizante nas culturas de arroz e milho, Betiol et al. (1983) constataram que tanto o biossólido quanto o organo-mineral IPT (fertilizante mineral acrescido com diferentes quantidades de biossólido) poderiam ser utilizados como fertilizantes, pois forneceram $\mathrm{N}, \mathrm{P}$ e micronutrientes para essas culturas.

Ao determinar, sob condições de laboratório, o efeito do biossólido digerido aerobiamente e anaerobiamente sobre as atividades da urease e fosfatase do solo, Bonmati et al. (1985) verificaram que ambos os biossólidos proporcionaram aumento nas concentrações de C-orgânico, N-total e P extraível em EDTA do solo. Enquanto que somente o biossólido anaeróbio proporcionou aumentou no nível de atividade da urease e da fosfatase do solo.

Após incorporarem doses de 0 a $225 \mathrm{Mg} \mathrm{ha}^{-1}$ de biossólido (base seca) de diferentes origens, doméstico e industrial, em incrementos de $45 \mathrm{Mg} \mathrm{ha}^{-1}$, em um solo argiloso, durante um período de oito anos, Williams et al. (1987) observaram, independentemente da dose, uma elevação no $\mathrm{pH}$ do solo que recebeu o biossólido doméstico. Este aumento segundo os autores resultou da predominância no biossólido de íons $\mathrm{N}_{-} \mathrm{NO}_{3}{ }^{-}$em relação aos íons $\mathrm{N}-\mathrm{NH}_{4}{ }^{+}$. Dessa forma o biossólido atuou como um fertilizante nitrogenado quando adicionado ao solo. Por outro lado, a acidez, e sua elevação, observada no solo que recebeu o biossólido industrial resultou dos altos teores 
de $\mathrm{N}-\mathrm{NH}_{4}{ }^{+}$.

Cunningham et al. (1975), incorporando biossólido digerido anaerobiamente ao solo obtiveram aumento na produção de grãos de milho, que se relacionou à maior disponibilidade de N, P e K. Da mesma forma, Fresquez et al. (1990) observaram um aumento linear nos teores de N, P e K do solo e aumento de produtividade da pastagem degradada de uma região semi-árida ao aplicarem biossólido. Entretanto, com relação ao elemento K, Linden et al. (1983) e Silva (1995) ressaltam a ocorrência da baixa concentração deste elemento no biossólido, sendo necessária a sua complementação, visando atender às necessidades das plantas. Também Oliveira et al. (1995), ao avaliar os efeitos de doses crescentes de biossólido complementadas ou não com $\mathrm{N}$ ou $\mathrm{K}$ sobre a absorção de macronutrientes na cultura de sorgo granífero, constataram a necessidade de complementar o biossólido com $\mathrm{K}$ afim de atender às necessidades da cultura.

Ao avaliar os efeitos do uso agrícola de biossólido na fertilidade do solo e na qualidade da cana de açúcar, Silva (1995) constatou que o biossólido mostrou-se adequado como corretivo do complexo coloidal do solo e como fertilizante para a cana de açúcar, principalmente como fonte de $\mathrm{Ca}, \mathrm{P}, \mathrm{S}$ e $\mathrm{Zn}$, refletindo em aumentos lineares de produtividades em biomassa e açúcar. Ressaltou, entretanto, que os citados efeitos do biossólido foram de curta duração, restringindo-se apenas a um ano agrícola.

Em Latossolo Vermelho Escuro (LE), Oliveira et al. (1995) estudaram os efeitos da aplicação de doses crescentes de biossólido (0,5, 10 e $\left.20 \mathrm{Mg} \mathrm{ha}^{-1}\right)$ complementadas ou não com $\mathrm{N}$ ou $\mathrm{K}$ na cultura do sorgo granífero. Verificaram que o biossólido, em função de sua composição e de seu comportamento no solo, liberou os nutrientes $\mathrm{N}, \mathrm{P}$, $\mathrm{Ca}, \mathrm{Mg}$ e $\mathrm{S}$ que foram absorvidos pela cultura, entretanto, para atender às necessidades da planta, foi necessária a complementação do biossólido com K. Segundo os autores, a aplicação de biossólido em doses superiores a $20 \mathrm{Mg} \mathrm{ha}^{-1}$ podem proporcionar melhores resultados no desenvolvimento do sorgo granífero.

De acordo com Benckiser \& Simarmata (1994), para uma fertilização adequada com a aplicação de biossólidos é necessário ter um exato conhecimento do conteúdo de nutrientes disponível no biossólido. Concentrações totais de $\mathrm{N}, \mathrm{P}, \mathrm{K}, \mathrm{Ca}$ e $\mathrm{Mg}$ da ordem de, respectivamente, $0-30,0-4,5,0-2,0-17,7$ e $0-3 \mathrm{~g} \mathrm{~kg}^{-1}$ na matéria seca do biossólido 
são consideradas baixas enquanto que concentrações, respectivamente, de 70-100, 6,8$17,5,4-6,2,36,4-71,5$ e $6,1-9 \mathrm{~g} \mathrm{~kg}^{-1}$ são consideradas altas.

Áo avaliar o comportamento de algumas características químicas de um Latossolo Vermelho Escuro (LE), textura média, após a aplicação de diferentes doses de biossólido, Marques et al. (1991) constataram que a aplicação de $32 \mathrm{Mg} \mathrm{ha}^{-1}$ de biossólido proporcionou uma elevação considerável da CTC, passando de aproximadamente 63 para $78 \mathrm{mmol}_{\mathrm{c}} \mathrm{dm}^{-3}$, sendo que os valores máximos foram atingidos no período entre 80 e 120 dias após a instalação do experimento. Também Melo et al. (1994), verificaram que somente na aplicação de maior dose de biossólido, correspondente a $32 \mathrm{Mg} \mathrm{ha}^{-1}$, houve aumento significativo no teor de C-orgânico e na CTC do solo LE e sua maior eficiência em relação a fertilização mineral, na maioria das amostragens.

Segundo Sikora \& Wolt (1986) o crescimento do milho (Zea mays L.) em solos tratados com biossólidos é muito favorecido, porque esta cultura apresenta alta capacidade de assimilação de $\mathrm{N}$.

Em ensaio em casa de casa de vegetação, Berton et al. (1989) estudaram as alterações nas propriedades químicas e na disponibilidade de $\mathrm{N}, \mathrm{P}, \mathrm{K}, \mathrm{Ca}, \mathrm{Mg}, \mathrm{Zn}$ e $\mathrm{Cu}$, em cinco solos representativos do Estado de São Paulo, decorrentes da incorporação de 0, 40 e $80 \mathrm{Mg} \mathrm{ha}^{-1}$ de biossólido, base seca, usando o milho como planta teste. Os resultados mostraram que a incorporação do biossólido proporcionou elevação de $\mathrm{pH}$ em todos os solos, reduzindo ou eliminando os teores de Al trocável. A adição de biossólido também aumentou o rendimento da matéria seca das plantas, bem como as quantidades de $\mathrm{N}, \mathrm{P}, \mathrm{Ca}, \mathrm{Mg}$ e $\mathrm{Zn}$ absorvidas. Nem mesmo na dose mais alta de biossólido, a absorção de $\mathrm{Cu}$ e $\mathrm{Zn}$ pelas plantas chegou a atingir níveis que pudessem causar redução na produção de matéria seca pela parte aérea do milho.

Estudando culturas diferentes Lourenço et al. (1996) verificaram aumentos significativos na produtividade do milho e feijão, dentro de um sistema agroflorestal com bracatinga, recomendando doses de biossólido até $6,5 \mathrm{Mg} \mathrm{ha}^{-1}$, base seca, aplicadas superficialmente e sem incorporação, para a otimização da produtividade de ambas as culturas, que, no caso atingiu valores de $3.000 \mathrm{~kg} \mathrm{ha}^{-1}$ e $300 \mathrm{~kg} \mathrm{ha}^{-1}$, respectivamente. 
Biscaia \& Miranda (1996), após incorporarem doses de 2, 4, 6 e $60 \mathrm{Mg} \mathrm{ha}^{-1}$, base seca, de biossólido resultante de digestão aeróbia e tratamento com cal em um Cambissolo e cultivarem milho (Zea mays L.), observaram que na maior dose não ocorreu sintomas de toxidez na cultura do milho e ainda houve uma resposta em produtividade da ordem de 7,62 $\mathrm{Mg} \mathrm{ha}^{-1}$, porém ressalvam que como o experimento foi realizado em solo de relativa fertilidade, bem corrigido, partiu-se de um patamar de produtividade razoável (aproximadamente $5 \mathrm{Mg} \mathrm{ha}^{-1}$ ), onde o acréscimo de biossólidos foi elevando esta produtividade.

Em estudo conduzido por Souza et al. (1998) em dois tipos de solo, Latossolo Roxo (LR) e Latossolo Vermelho Escuro (LE), foram aplicadas doses 0, 2,49; 4,97; 9,94 $\mathrm{Mg} \mathrm{ha}^{-1}$ de biossólido, a lanço, sendo posteriormente incorporadas e cultivado milho (Zea mays L.). Os resultados mostraram que somente no LR ocorreu diferenças significativas entre a produção de matéria seca da testemunha $\left(5,10 \mathrm{Mg} \mathrm{ha}^{-1}\right)$ e do tratamento que recebeu a maior dose de biossólido $\left(6,15 \mathrm{Mg} \mathrm{ha}^{-1}\right)$ : Com relação ao rendimento dos grãos, verificaram uma tendência de maior produção no LE.

Algumas pesquisas também relacionam os efeitos positivos da aplicação de biossólidos nos atributos fisicos do solo, tais como densidade, infiltração, condutividade hidráulica e estabilidade dos agregados.

Wei et al. (1985) aplicaram, em 1977, doses de $0 ; 11,2 ; 22,4 ; 44,8$ e 112,0 Mg $\mathrm{ha}^{-1}$ de biossólidos, base seca, em um solo franco argilo siltoso. Um sexto tratamento foi realizado com aplicações anuais de $22,4 \mathrm{Mg} \mathrm{ha}^{-1}$ de 1977 a 1982 , resultando em uma aplicação total de $134,4 \mathrm{Mg} \mathrm{ha}^{-1}$. As medições de densidade aparente, infiltração, condutividade hidráulica e estabilidade dos agregados foram feitas em todos os tratamentos cinco anos após as aplicações. Verificaram que a densidade aparente do solo diminui quando aplicaram quantidades de biossólido maior ou igual a $44,8 \mathrm{Mg} \mathrm{ha}{ }^{-1}$, incluindo o tratamento que recebeu aplicações anuais de $22,4 \mathrm{Mg} \mathrm{ha}^{-1}$. As condutividades hidráulicas do solo saturado dos tratamentos que receberam 11,$2 ; 22,4$; 44,8; 112,0 e $134,4 \mathrm{Mg} \mathrm{ha}^{-1}$ de biossólido aumentaram respectivamente em 0; 4,2; 45,$4 ; 70,2$ e 70,6\% em relação ao tratamento controle. A melhoria da permeabilidade do solo foi devido ao aumento da estabilidade dos agregados. Observaram também que o 
conteúdo de umidade dos solos que receberam biossólido foi sempre maior que o do controle, especialmente após um período prolongado de evaporação e que a $33,3 \mathrm{kPa}$ ou menos, mais água foi liberada dos solos tratados com altas doses de biossólido. Isto indicou um aumento no volume dos poros maiores, que resultou nas maiores condutividades hidráulicas. Os tratamentos que receberam as menores aplicações de biossólido (11,2 e 22,4 $\mathrm{Mg} \mathrm{ha}^{-1}$ ) não influenciaram as propriedades físicas do solo após os cinco anos. Entretanto, pequenas aplicações anuais melhoraram as propriedades fisicas do solo igualmente a uma única grande aplicação.

Em estudo com incorporação, a $20 \mathrm{~cm}$, de quantidades crescentes de biossólidos $\left(0,45,90,135,180\right.$ e $225 \mathrm{Mg} \mathrm{ha}^{-1}$ ano $^{-1}$, base seca) em um solo argiloso durante um período de oito anos, Williams et al. (1987) verificaram que a densidade aparente do solo geralmente diminuiu com as doses crescentes de biossólido.

Ao estudar as possíveis alterações na porosidade, agregação, retenção e infiltração de água num Latossolo Vermelho Escuro (LE) quatro anos após a aplicação de biossólido e calcário, Jorge et al. (1991) constataram que a quantidade de agregados com diâmetro médio superior a $1 \mathrm{~mm}$ aumentou significativamente nos tratamentos com biossólido sem calcário e no tratamento com calcário em que $80 \mathrm{Mg} \mathrm{ha}^{-1}$ de biossólido foram aplicados em quatro anos $\left(20 \mathrm{Mg} \mathrm{ha}^{-1}\right.$ ano $\left.^{-1}\right)$. O índice de agregação aumentou com a quantidade de biossólido aplicada ao solo, passando de 0,76 para 1,44 nos tratamentos sem calcário e de 0,47 para 1,05 com calcário. A aplicação de $40 \mathrm{e}$ $80 \mathrm{Mg} \mathrm{ha}^{-1}$ de biossólido de uma só vez favoreceu a formação de macroporos e a de 80 $\mathrm{Mg} \mathrm{ha}^{-1}$ fracionada (4 x $20 \mathrm{Mg} \mathrm{ha}^{-1} \mathrm{ano}^{-1}$ ) favoreceu o aumento relativo de microporos.

Após incorporarem $500 \mathrm{Mg} \mathrm{ha}^{-1}$, base seca, de $\mathrm{N}$-Viro, material oriundo da estabilização alcalina do biossólido desidratado com um ou mais produtos alcalinos industriais, em um solo franco siltoso, Logan \& Harrison (1995) observaram que decorrido um ano da aplicação ocorreu uma diminuição na densidade aparente do solo, um aumento na estabilidade dos agregados e na condutividade hidráulica. Todas estas mudanças foram benéficas e estatisticamente significativas. 


\subsection{Riscos ambientais da reciclagem agrícola de biossólidos}

\subsubsection{Observações gerais}

Apesar das vantagens, a aplicação de biossólidos em áreas agrícolas pode constituir perigo, devido a presença de poluentes químicos e agentes causadores de doenças. No solo, os patógenos gradualmente morrem e não apresentam efeito prejudicial a longo prazo. Entretanto, os poluentes químicos do biossólido, especialmente metais e elementos traços, podem persistir nos solos indefinidamente e serem absorvidos pelas plantas em crescimento em quantidades suficientes para afetar adversamente a saúde dos consumidores e/ou o desenvolvimento das próprias plantas (Chang et al. 1997).

A utilização agrícola de biossólidos representa risco maior para o ambiente, principalmente quando é proveniente de cidades altamente industrializadas sem coleta ou tratamento especifico. A esse respeito, Sommers (1977) comenta sobre a natureza heterogênea dos biossólidos produzidos em diferentes cidades e ressalta a necessidade do conhecimento individual da composição química de cada biossólido antes de aplicálo em terras agricolas.

Segundo Webber (1988) existem dois tipos de riscos ambientais associado com a utilização de biossólido na agricultura, temporários e persistentes. Os riscos temporários desaparecem dentro de um ano ou de poucos anos, após a aplicação do biossólido no solo, e incluem odor, patógenos, contaminação das águas subterrâneas com $\mathrm{N}-\mathrm{NO}_{3}^{-}$, além de fitotoxicidade devido a presença de sais solúveis ou produtos tóxicos biodegradáveis oriundos de biossólidos inadequadamente estabilizados. Os riscos

persistentes permanecem por muito tempo após os riscos temporários terem desaparecido e incluem $\mathrm{o}$ aumento das concentrações de compostos orgânicos produzidos industrialmente e não biodegradáveis, tais como bifenis policloridratos (PCB's) e o aumento da concentração de metais pesados no solo.

A deposição desses metais no solo também constitui fator de grande importância para a ecologia microbiana. Muitos desses metais como $\mathrm{Zn}, \mathrm{Cu}$ e $\mathrm{Fe}$ são essenciais aos 
microrganismos, mas tornam-se tóxicos quando presentes em concentrações elevadas no solo ou nos substratos orgânicos em decomposição (Siqueira \& Franco, 1988). A maior parte dos metais pesados isolados ou em certos compostos exercem ação deletéria sobre os microrganismos, podendo também promover as seguintes reduções: na abundância e diversidade da microbiota do solo; na formação e atividade de simbioses radiciais e na decomposição, mineralização e na respiração do solo, além de interferir nas transformações do nitrogênio e atividades enzimáticas do solo (Pelczar et al., 1980; Siqueira et al., 1994)

Os metais pesados de maior preocupação nos biossólidos são: $\mathrm{Cd}, \mathrm{Cr}, \mathrm{Cu}, \mathrm{Hg}$, $\mathrm{Mo}, \mathrm{Ni}, \mathrm{Pb}, \mathrm{Zn}$ e $\mathrm{Ag}$, devido à sua ocorrência generalizada, ao potencial de fitotoxicidade e aos danos a animais e humanos (Chang et al. 1997; Lucchesi, 1998). Por outro lado, levantamentos publicados nos Estados Unidos sobre lodos de esgoto primários levaram à seguinte ordem em termos de abundância: $\mathrm{Zn}>\mathrm{Pb}>\mathrm{Ni}>\mathrm{Cd}>\mathrm{Hg}$ (Lucchesi, 1998).

Desses metais, o $\mathrm{Cd}$ é considerado o elemento mais perigoso, devido ao seu comportamento químico no solo e a habilidade das plantas e dos animais em acumulá-lo, razão pela qual usualmente existem considerações especiais nos manuais das agências de proteção ambiental a seu respeito (Kim et al., 1988; Hegstrom \& West, 1989).

\subsubsection{Lixiviação de espécies químicas em solos tratados com biossólidos}

2.2.2.1 Lixiviação de $\mathrm{K}^{+}, \mathrm{Ca}^{2+}, \mathrm{Mg}^{2+}$ e metais pesados

Existe uma certa preocupação acerca do uso agrícola de biossólidos no que diz respeito a possibilidade de movimentação e conseqüente contaminação de camadas subsuperficiais do solo e águas subterrâneas por metais (Lund et al., 1976; Welch \& Lund, 1989; Dowdy et al., 1991; Oliveira, 1995; Bertoncini, 1997).

Os estudos onde se tem aplicado biossólidos ao solo e monitorado a lixiviação de metais apresentam resultados fragmentados e inconsistentes. 
Embora fossem aplicadas quantidades equivalentes a $4,5 \mathrm{Mg} \mathrm{ha}^{-1} \mathrm{CaCO}_{3}$ e 112 $\mathrm{Mg} \mathrm{ha}{ }^{-1}$ de biossólido, base seca, na superficie de um solo argiloso e caulinítico, Tan et al. (1985) observaram que as perdas por lixiviação de $\mathrm{Ca}^{2+}, \mathrm{K}^{+}, \mathrm{Mg}^{2+}, \mathrm{Ai}^{3+}, \mathrm{Fe}^{2+}, \mathrm{Zn}^{2+} \mathrm{e}$ Cd após a percolação de água foram muito pequenas.

Todavia, Riekerk (1978) ao aplicar $247 \mathrm{Mg} \mathrm{ha}^{-1}$ de biossólido, base seca, em um solo florestal cascalhento verificou que as primeiras perdas anuais devido ao tratamento foram $8 \%$ do $\mathrm{N}$ adicionado, $15 \%$ do $\mathrm{Ca}, 1 \%$ do $\mathrm{K}$, e $0 \%$ de $\mathrm{P}$.

Após irrigarem anualmente um solo franco siltoso com biossólido tratado durante três anos e aplicarem anualmente $269 \mathrm{~kg} \mathrm{ha}^{-1}$ de $\mathrm{K}$, na forma de $\mathrm{KCl}$, antes de cultivarem o milho, Jones \& Hinesley (1986) observaram perdas de $\mathrm{K}^{+}$por lixiviação da ordem de $8,2 \mathrm{~kg} \mathrm{ha}^{-1}$ e concentrações médias de $\mathrm{K}^{+}$total recuperado de $4,8 \mathrm{mg} \mathrm{L}^{-1}$ no primeiro ano e de $2,4 \mathrm{mg} \mathrm{L}^{-1}$ durante o segundo ano. Concluíram que as perdas de $\mathrm{K}^{+}$ foram pequenas quando comparadas com as quantidades fornecidas pelo fertilizante, pelo biossólido e pelo próprio solo, considerando tanto teor total quanto extraível com $\mathrm{HCl} 0,1 \mathrm{~mol} \mathrm{~L}^{-1}$.

Em estudo com aplicação crescente de grandes quantidades de biossólidos $(0,45$, $90,135,180$ e $225 \mathrm{Mg} \mathrm{ha}^{-1}$ ano $^{-1}$, base seca) de diferente origens, doméstico e industrial, em um solo argiloso durante um período de oito anos, Williams et al. (1987) constataram que não ocorreu movimento significativo de $\mathrm{Cd}^{2+}, \mathrm{Zn}^{2+}, \mathrm{Ni}^{2+}, \mathrm{Co}^{2+}, \mathrm{Fe}^{2+} \mathrm{e}$ $\mathrm{Mn}^{2+}$ após o término das aplicações de biossólido.

Ao estudarem a solução de um solo argiloso tratado com 0, 150 e $330 \mathrm{Mg} \mathrm{ha}^{-1}$ de biossólido, base seca, decorridos sete anos da aplicação, Campbell \& Beckett (1988) observaram que os íons nitrato, sulfato, $\mathrm{Mg}^{2+}, \mathrm{Ca}^{2+}, \mathrm{Sr}^{2+}, \mathrm{B}(\mathrm{OH})_{4}$ e possivelmente $\mathrm{Ba}^{2+}$ estavam ainda movendo-se através do perfil do solo, podendo atingir provavelmente o lençol freático. As concentrações de $\mathrm{Cu}^{2+}$ e $\mathrm{Zn}^{2+}$ na solução do solo tratado foram maiores, em todas as profundidades, que as encontradas no tratamento testemunha, porém diminuíram acentuadamente como aumento da profundidade, não sendo possível a lixiviação destes elementos para o lençol freático.

Medalie et al. (1994) aplicaram superficialmente, sem incorporação, em junho de 1989,$0 ; 3,3 ; 6,9$ e $14,5 \mathrm{Mg} \mathrm{ha}^{-1}$ de biossólido, base seca, em um solo florestal franco 
arenoso com muita ocorrência de pedras e constataram que as concentrações de $\mathrm{N}-\mathrm{NO}_{3}{ }^{-}$, $\mathrm{N}-\mathrm{NH}_{4}{ }^{+}, \mathrm{Cl}^{-}, \mathrm{PO}_{4}{ }^{3-}, \mathrm{SO}_{4}{ }^{2-}, \mathrm{Ca}^{2+}, \mathrm{Mg}^{2+}, \mathrm{Na}^{+}, \mathrm{e} \mathrm{K}^{+}$permaneceram baixas até setembro, quando, simultaneamente, as concentrações de $\mathrm{N}-\mathrm{NO}_{3}{ }^{-}, \mathrm{Cl}^{-}, \mathrm{Ca}^{2+}, \mathrm{Mg}^{2+}, \mathrm{Na}^{+}, \mathrm{e} \mathrm{K}^{+}$, no experimento que excluiu a presença da vegetação, passaram a aumentar atingindo valores máximos nos meses de outubro ou novembro (dependendo do íon e da dose considerados). Nas áreas em que não se considerou a presença das plantas, $\mathrm{o} \mathrm{N}^{-\mathrm{NO}_{3}}{ }^{-}$foi o ânion dominante na solução e as concentração de $\mathrm{K}^{+}$foram sempre menores que as de $\mathrm{Ca}^{2+}, \mathrm{Mg}^{2+} \mathrm{e} \mathrm{Na}^{+}$. Nas áreas com e sem efeito da absorção das plantas, as concentrações de $\mathrm{N}_{-} \mathrm{NH}_{4}{ }^{+}, \mathrm{PO}_{4}{ }^{3-}, \mathrm{SO}_{4}{ }^{2-}$ e $\mathrm{K}^{+}$e $\mathrm{o} \mathrm{pH}$ da solução do solo não se modificaram significativamente com nenhuma das doses de biossólido. Os autores sugeriram que em aplicações de até $14,5 \mathrm{Mg} \mathrm{ha}^{-1}$ de biossólido, base seca, uma combinação de fatores físicos, químicos e biológicos limitam o movimento do biossólido ou dos constituintes oriundos deste resíduo.

Ao estudar o comportamento dos metais pesados e de formas nitrogenadas em dois solos distintos, Areia Quartzosa (AQ) e Latossolo Roxo (LR), ajustados a dois níveis de pH 3,9 e 4,9 e, posteriormente tratados com doses de biossólidos equivalentes a $0 ; 13,5 ; 29,7$ e $40,5 \mathrm{Mg} \mathrm{ha}^{-1}$, base seca, Oliveira (1995) verificou que a movimentação e ou lixiviação dos metais ao longo das colunas de solos foi evidente apenas para o $\mathrm{Mn}^{2+}$ e $\mathrm{Zn}^{2+}$. Para o autor a lixiviação do $\mathrm{Mn}^{2+}$ não ocorreu devido às quantidades adicionadas via biossólido e sim pela abundância desse metal nos solos utilizados no experimento. Os maiores aumentos nas quantidades lixiviadas de $\mathrm{Zn}^{2+}$ ocorreram principalmente no solo AQ. Ressaltou preocupação em relação a este metal, visto sua ocorrência em grande quantidade no biossólido, sua relativa facilidade de movimentação no perfil dos solos e o desconhecimento dos seus efeitos sobre o ambiente.

Também Miyazawa et al. (1996), após adicionarem quantidades equivalentes a 5 , 50 e $100 \mathrm{Mg} \mathrm{ha}^{-1}$ de biossólido, base seca, na superficie de solos LRd argiloso e LEd arenoso, acondicionados em colunas de PVC e a plicarem água na superficie da coluna a cada 15 dias ao longo de 12 meses até completar o volume equivalente a $1.495 \mathrm{~mm}$ de chuva, verificaram que entre os metais pesados estudados $\mathrm{Ba}^{2+}, \mathrm{Cd}^{2+}, \mathrm{Co}^{2+}, \mathrm{Cr}, \mathrm{Cu}^{2+}, \mathrm{Ni}^{2+}$, 
$\mathrm{Pb}^{2+}$ e $\mathrm{Zn}^{2+}$, somente a concentração de $\mathrm{Zn}^{2+}$ aumentou (10\%) até a camada de $5-10 \mathrm{~cm}$ nos solos com valores de $\mathrm{pH}$ próximos a 4,0, sendo mínimo o deslocamento nos solos com pH igual a 5,8 .

Embora genericamente se assuma que os metais oriundos da aplicação de biossólido sejam imóveis em solos agrícolas manejados, há fatores que aumentam a mobilidade desses metais resultando numa maior absorção pela planta ou lixiviação para as águas subterrâneas. Estes fatores incluem as propriedades do metal em questão, quantidade e tipo de sitios de ligação do solo, $\mathrm{pH}$, concentração de ânions complexantes (orgânicos e inorgânicos) e de cátions competitivos na solução do solo (Camobreco et al., 1996).

Ao estudar o movimento de $\mathrm{Zn}^{2+}$ em solos tratados com biossólidos, Welch \& Lund (1989) verificaram que o teor total de $\mathrm{Zn}^{2+}$ lixiviado e a profundidade de movimentação deste elemento no solo foram negativamente correlacionados com o pH final do solo. A análise de regressão linear múltipla mostrou que no experimento em colunas insaturadas o $\mathrm{pH}$ final do solo explicou $72 \%$ da variação das quantidades totais de $\mathrm{Zn}^{2+}$ lixiviado e $82 \%$ da variação do movimento do $\mathrm{Zn}^{2+}$ em profundidade. Também observaram que não houve correlação significativa entre este elemento e o carbono orgânico da solução do solo.

Ao determinar as taxas de lixiviação a curto prazo dos metais $\mathrm{Cd}^{2+}, \mathrm{Cu}^{2+}, \mathrm{Fe}^{2+}$, $\mathrm{Pb}^{2+}$ e $\mathrm{Zn}^{2+}$, oriundos de biossólidos compostados, em soluções tamponadas com $\mathrm{pH}$ variando de 2,5-7,0 com intervalos de 0,5 unidade, Tackett et al. (1986) constataram que as concentrações de $\mathrm{Zn}^{2+}$ e $\mathrm{Cd}^{2+}$ aumentaram com o decréscimo de $\mathrm{pH}$, sendo que para ambos os elementos os maiores aumentos ocorreram entre valores de $\mathrm{pH}$ de 6,0 e 5,5, enquanto que a curto prazo não ocorreram mudanças nas concentrações de $\mathrm{Fe}^{2+}, \mathrm{Cu}^{2+} \mathrm{e}$ $\mathrm{Pb}^{2+}$.

Lamy et al. (1993) aplicaram $11 \mathrm{Mg} \mathrm{ha}^{-1}$ de biossólido, base seca, em um solo hidromórfico e monitoraram o teor de $\mathrm{Cd}^{2+}$ e matéria orgânica solúvel presente na água drenada após a aplicação deste resíduo. Os resultados demonstraram que na água drenada das parcelas onde foi aplicada maior quantidade de material orgânico havia duas vezes mais $\mathrm{Cd}^{2+}$ que na testemunha, nas primeiras semanas após aplicação do biossólido. 
Estudos feitos em laboratório para estimar as interações entre $\mathrm{Cd}^{2+}$, matéria orgânica solúvel do biossólido e solo, indicaram a ocorrência de maior formação de complexos orgânicos solúveis com $\mathrm{Cd}^{2 *}$ na faixa de $\mathrm{pH}$ de 5 a 7 e maior retenção do metal em meio ácido $(\mathrm{pH}<5)$ e em $\mathrm{pH}$ maior que 7. Desta forma, em solos ácidos ou naqueles em que o pH é mantido próximo a neutralidade $(6,5$ - 7,0) a aplicação de biossólidos seria limitada, devido a mobilidade de $\mathrm{Cd}^{2+}$ que poderia atingir o lençol freático.

De acordo com Singh \& Steinnes (1994) o transporte de metais pesados dentro do solo ou mesmo para as águas subterrâneas depende da concentração do metal na solução do solo. Todavia, os processos que determinam as concentrações dos metais na solução do solo ainda não são completamente entendidos. Mudanças no conteúdo de água do solo, saída do equilíbrio ou do equilíbrio dinâmico para condição de não equilíbrio e mudanças na atividade dos microrganismos que influenciam condições redox, conteúdo de agentes quelantes solúveis e composição da atmosfera do solo precisam ser simultaneamente considerados. Estes processos afetam as reações químicas com os metais pesados, tais como precipitação-dissolução, adsorção-desorção, complexação e formação de par iônico e assim influenciam a distribuição das diversas espécies metálicas na fase sólida do solo e na solução do solo.

Ao estudar o movimento de $\mathrm{Zn}^{2+}, \mathrm{Cd}^{2+}, \mathrm{Cu}^{2+}, \mathrm{Cr}$ e $\mathrm{Ni}^{2+}$ em solos de textura arenosa que serviam como reservatórios de disposição de biossólido, Lund et al. (1976) verificaram que a distribuição dos metais em profundidade estava fortemente relacionada com mudanças na demanda química de oxigênio que ocorria em profundidade. Considerando tal fato, os autores sugeriram que os metais lixiviaram na forma de complexos organo-metálico solúveis.

Em estudos com colunas de solo saturado e insaturado, Wech \& Lund (1987) analisaram o movimento de $\mathrm{Ni}^{2+}$ em solos tratados com $300 \mathrm{Mg} \mathrm{ha}^{-1}$ de biossólidos, base seca. Os resultados mostram que nas colunas com solo saturado em média $3,3 \%$ do $\mathrm{Ni}^{2+}$ aplicado lixiviou, permanecendo $74,9 \%$ de $\mathrm{Ni}^{2+}$ acumulado na profundidade de $0-3 \mathrm{~cm}$, enquanto que nas colunas com solo insaturado lixiviou $10,7 \%$, permanecendo apenas $46,5 \%$ de $\mathrm{Ni}^{2+}$ acumulado nesta profundidade. Nas colunas insaturadas, $\mathrm{O} \mathrm{Ni}^{2+}$ lixiviado foi mais uniformemente distribuído com a profundidade do solo. Também observaram 
que o movimento de $\mathrm{Ni}^{2+}$ em profundidade foi positivamente correlacionado com o teor de areia dos solos e negativamente correlacionado com os teores de argila, silte e com $\mathrm{pH}$ final do solo.

Os metais podem se ligar ao solo através de processos de troca iônica e quimiosorção. Óxidos de $\mathrm{Fe}, \mathrm{Al}$ e $\mathrm{Mn}$ podem fornecer os sítios de quimiosorção para os metais. A matéria orgânica também é importante na complexação e retenção dos metais. Os minerais silicatados em camada fornecem sítios de troca para os cátions, bem como sítios de pouca quimiosorção nas arestas quebradas de cristais. Muitos metais em níveis altos de contaminação formam precipitados com óxidos, hidróxidos e carbonatos, especialmente em pH de solo elevado (Camobreco et al., 1996).

A matéria orgânica, tanto solúvel quanto insolúvel, forma complexos com os metais através de reações de troca e quimiosorção. Os metais podem se ligar com os grupos funcionais carboxílicos, fenólicos, alcólicos, carbonílicos e metoxílicos. Quando dois ou mais grupos funcionais se ligam com um simples ín metálico resulta um anel de quelação de cinco ou seis membros que retém o metal fortemente. A quelação é pH dependente, pois em $\mathrm{pH}$ baixo os metais competem com os íns $\mathrm{H}^{+}$pelos sítios de coordenação dos grupos funcionais (Camobreco et al., 1996).

Os compostos orgânicos que naturalmente ocorrem nos solos são agentes efetivos para quelação de metais e a solubilidade dos quelatos metálicos depende da força de ligação e da mobilidade dos quelatos assim formados. A forte ligação de metais com uma substância orgânica de baixo peso molecular aumenta apreciavelmente sua mobilidade no solo (Singh e Steinnes, 1994).

Segundo Reddy et al. (1995), próximo ao $\mathrm{pH}$ neutro a concentração de $\mathrm{Cu}^{2+}, \mathrm{Zn}^{2+}$ e $\mathrm{Pb}^{2+}$ dissolvida na solução do solo é predominantemente formada por complexos de metal com carbono orgânico solúvel.

Camobreco et al. (1996) aplicaram soluções diluídas de $\mathrm{CdCl}_{2}, \mathrm{ZnCl}_{2}, \mathrm{CuCl}_{2}$ e $\mathrm{Pb}\left(\mathrm{NO}_{3}\right)_{2}$ em colunas de solo homogeneizado e não homogeneizado. Quatro colunas receberam 7,25 $\mathrm{mg} \mathrm{L}^{-1}$ de Cd, 4,55 $\mathrm{mg} \mathrm{L}^{-1}$ de $\mathrm{Zn}, 3,51 \mathrm{mg} \mathrm{L}^{-1}$ de $\mathrm{Cu}$ e $13,85 \mathrm{mg} \mathrm{L}^{-1}$ de $\mathrm{Pb}$. Outras quatro colunas receberam a mesma solução, porém contendo matéria orgânica solúvel, de modo que os metais encontravam-se organicamente complexados. 
Nestas colunas foram aplicados $6,30 \mathrm{mg} \mathrm{L}^{-1}$ de Cd, 4,11 $\mathrm{mg} \mathrm{L}^{-1}$ de $\mathrm{Zn}, 3,19 \mathrm{mg} \mathrm{L}^{-1} \mathrm{de}$ $\mathrm{Cu}$ e $12,55 \mathrm{mg} \mathrm{L}^{-1}$ de $\mathrm{Pb}$. Os resultados demonstraram que a matéria orgânica solúvel influenciou o transporte de metais. Nas colunas que receberam os metais dissolvidos em água destilada, a ordem de mobilidade dos metais foi $\mathrm{Cd}^{2+}>\mathrm{Zn}^{2+}>>\mathrm{Cu}^{2+}>\mathrm{Pb}^{2+}$, enquanto que nas colunas onde se aplicou os metais complexados organicamente a mobilidade foi $\mathrm{Cd}^{2+} \approx \mathrm{Cu}^{2+}>\mathrm{Zn}^{2+} \approx \mathrm{Pb}^{2+}$. Os agentes quelantes orgânicos aumentaram a

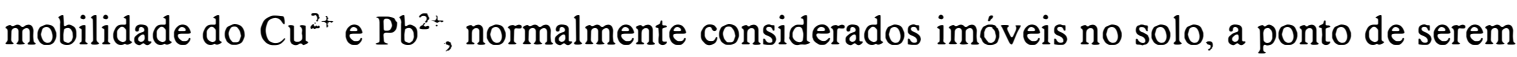
comparados com a mobilidade do $\mathrm{Cd}^{2+}$ e $\mathrm{Zn}^{2+}$.

O fluxo preferencial também tem sido apresentado como um fator que aumenta muito a mobilidade e a velocidade do movimento dos solutos para as águas subterrâneas (Camobreco et al., 1996).

Conforme Singh \& Steinnes (1994) a relativa mobilidade de diferentes metais pode ser aproximadamente expressa pela razão da quantidade dissolvida pela quantidade ligada de cada metal em relação ao $\mathrm{pH}$. De acordo com esta interpretação e com o conceito de hidrólise de íons metálicos, a mobilidade dos metais pesados em solos ácidos decresce na seguinte ordem $\mathrm{Cd}^{2+}>\mathrm{Ni}^{2+}>\mathrm{Zn}^{2+}>\mathrm{Mn}^{2+}>\mathrm{Cu}^{2+}>\mathrm{Pb}^{2+}>\mathrm{Hg}^{2+}$.

Camobreco et al. (1996) comentam, porém, que o conhecimento do movimento destes metais é baseado em estudos de coluna de solo homogeneizado e sob estas condições nenhum desses metais parece ser móvel (especialmente quando aplicado via biossólido), exceto talvez em solos muito ácidos de textura arenosa.

Estudos realizados por Camobreco et al. (1996) comprovaram que o fluxo preferencial é importante no transporte de metais através do solo. Todos os metais aplicados na forma de cloretos dissolvidos tanto em água quanto em solução orgânica ficaram adsorvidos nas colunas com solo homogeneizado enquanto que nas colunas com solo não homogeneizado ocorreu a lixiviação de alguns metais. O solo utilizado no experimento, conforme demostraram as colunas homogeneizadas, tinha capacidade suficiente de adsorver todos os metais, porém o fluxo preferencial que ocorreu nas colunas contendo solo não homogeneizado permitiu que alguns metais passassem pelos sítios de ligação e fossem lixiviados. Os autores ressaltam que o experimento foi realizado aplicando-se metais na forma de sais, porém tal comportamento pode não se 
verificar ao se utilizar biossólidos como fonte de metais, pois o alto teor de matéria orgânica dos biossólidos poderia reter os metais fortemente, pelo menos inicialmente.

Ao contrário do observado por Camobreco et al. (1996), Bertoncini (1997) ao trabalhar com colunas de solo homogeneizado, utilizando os solos Areia Quartzosa (AQ), Latossolo Vermelho Amarelo (LV) e Latossolo Vermelho Escuro (LE), aos quais foram incorporadas quantidades sucessivas de biossólidos, correspondente a $156 \mathrm{Mg}$ $\mathrm{ha}^{-1}$, base seca, verificou que os elementos $\mathrm{Cd}^{2+}, \mathrm{Cr}$, e $\mathrm{Zn}^{2+}$ não foram lixiviados quando utilizou-se água como solução percolante, indicando que estes não se encontram na forma trocável nos solos tratados com biossólido. Entretanto, grandes quantidades de $\mathrm{Ca}^{2+}$ e $\mathrm{Mg}^{2+}$ foram encontradas nos lixiviados com água. A lixiviação de $\mathrm{Ni}^{2+}$ ocorreu apenas no solo $\mathrm{AQ}$, enquanto que o $\mathrm{Cu}^{2+}$ foi encontrado nos lixiviados de todos os tratamentos com biossólido, exceto no tratamento LE+lodo. A maior quantidade lixiviada de $\mathrm{Cu}^{2+}$ ocorreu no solo $\mathrm{AQ}$, no qual também foi observado as maiores perdas de C-orgânico solúvel em água, refletindo a ligação do $\mathrm{Cu}^{2+}$ a ligantes orgânicos solúveis.

\subsubsection{Lixiviação de nitrato}

$\mathrm{O} \mathrm{N}$ orgânico oriundo da aplicação de biossólidos no solo está sujeito a diversas transformações biológicas que são sensíveis ao $\mathrm{pH}$, umidade, temperatura e outros parâmetros ambientais do solo. Dependendo das condições do solo, o $\mathrm{N}$ liberado do biossólido tanto pode ser incorporado no tecido da planta e na matéria orgânica do solo como perdido no sistema através da volatilização, denitrificação, escorrimento superficial ou lixiviação (Cartron \& Weil, 1998). De acordo com estes autores a reciclagem agrícola de biossólido pode contribuir para a lixiviação e o escomimento superficial de nitrato $\left(\mathrm{N}^{-} \mathrm{NO}_{3}{ }^{-}\right)$, principalmente se a mineralização do $\mathrm{N}$ orgânico não é sincronizada com a absorção pela cultura. Shepherd (1996) e Gavi et al. (1997) também ressaltam que a aplicação de biossólido levando-se em consideração doses agronômicas de $\mathrm{N}$ minimiza o risco de contaminação do ambiente, enquanto que aplicações 
excessivas deste resíduo aumentam o risco de lixiviação de $\mathrm{N}-\mathrm{NO}_{3}{ }^{-}$e a contaminação das águas subterrâneas.

Riekerk (1978), ao aplicar $247 \mathrm{Mg} \mathrm{ha}^{-1}$ de biossólido, base seca, em um solo florestal, verificou que o ín móvel predominante foi o $\mathrm{N}_{-} \mathrm{NO}_{3}{ }^{-}$, o que favoreceu significantemente o aumento do nível de nitrato de cálcio no lençol freático.

Em trabalho feito por Jones \& Hinesly (1988), lisímetros foram instalados em uma área cultivada com milho, na qual aplicaram doses de biossólidos de maneira a fornecer uma quantidade de N-total de $2.292 \mathrm{~kg} \mathrm{ha}^{-1}$ em 1972 e $3.286 \mathrm{~kg} \mathrm{ha}^{-1}$ em 1973. As perdas anuais por lixiviação nos tratamentos que receberam biossólido foram de 663 e $371 \mathrm{~kg} \mathrm{ha}^{-1}$ de $\mathrm{N}-\mathrm{NO}_{3}^{-}$, o que correspondeu a uma concentração de 223 e $148 \mathrm{mg} \mathrm{L}^{-1}$ de $\mathrm{N}_{-} \mathrm{NO}_{3}^{-}$, respectivamente referem-se aos anos de 1972/1973 e 1973/1974. As maiores perdas por lixiviação de $\mathrm{N}-\mathrm{NO}_{3}{ }^{-}$ocorreram no final do inverno e início da primavera.

Estudando a lixiviação de nutrientes em solo florestal após a aplicação $0,3,3$, 6,9 e 14,5 $\mathrm{kg} \mathrm{ha}^{-1}$ de biossólidos, base seca, Medalie et al. (1994) observaram que o $\mathrm{N}-\mathrm{NO}_{3}{ }^{-}$foi o ânion dominante na solução do solo do experimento que excluiu a absorção pela vegetação. Além disso, verificaram em média um excesso de 0,71 mmol L ${ }^{-1}$ de $\mathrm{N}_{-} \mathrm{NO}_{3}{ }^{-}$, em relação ao padrão estabelecido para água potável de $10 \mathrm{mg} \mathrm{L}^{-1}$, em todas as doses aplicadas. As maiores concentrações de $\mathrm{N}_{-} \mathrm{NO}_{3}{ }^{-}$ocorreram nos tratamentos que receberam as maiores aplicações de biossólido. Nas áreas em que se levou em consideração a absorção pela vegetação, as concentrações de $\mathrm{N}-\mathrm{NO}_{3}{ }^{-}$ raramente excederam $0,001 \mathrm{mmol} \mathrm{L}^{-1}$.

As perdas de $\mathrm{N}^{-} \mathrm{NO}_{3}{ }^{-}$por lixiviação após a aplicação de biossólidos podem ser afetadas por outros fatores, além dos anteriormente citados, dentre eles destacam-se também método de tratamento das águas residuárias, época, modo de aplicação do biossólido, textura do solo e clima.

Segundo Shepherd (1996), a quantidade de N disponível no biossólido, isto é de $\mathrm{N}-\mathrm{NH}_{4}{ }^{+}$(forma mais facilmente mineralizável), é dependente do método de tratamento das águas residuárias e isto, por sua vez, afeta os riscos de lixiviação das formas nitrogenadas.

Em estudo conduzido no campo por Mench et al. (1989) em um solo ferralítico 
sob clima tropical húmido, foram aplicadas doses 0,10 e $100 \mathrm{Mg} \mathrm{ha}^{-1}$ de biossólido, base seca, incorporadas até a profundidade de $20 \mathrm{~cm}$. O solo foi mantido sem vegetação. Concluíram que $100 \%$, na dose 10 , e quase $61 \%$, na dose 100 , do $\mathrm{N}$ orgânico aplicado poderia ser liberado no ano seguinte. Quinze dias após a incorporação observaram que as quantidades máximas de $\mathrm{N}$ inorgânico na superfície do solo $(0-20 \mathrm{~cm})$ eram de $265 \mathrm{e}$ $1.140 \mathrm{~kg} \mathrm{ha}^{-1}$ de $\mathrm{N}$, respectivamente na dose 10 e 100. O N-NH${ }_{4}^{+}$desapareceu rapidamente do solo, enquanto que $\mathrm{N}-\mathrm{NO}_{3}{ }^{\circ}$ somente apareceu após 60 dias na dose de 10 $\mathrm{Mg} \mathrm{ha}{ }^{-1}$ e 120 dias na maior dose de biossólido. $\mathrm{O} \mathrm{N}^{-\mathrm{NO}_{3}}{ }^{-}$foi produzido e/ou persistiu na superfície do solo por um período de 120 dias, na dose 10, até a estação chuvosa ou além de um ano na dose 100. A lixiviação, exclusivamente da forma nítrica, foi de 218 , 389 e $920 \mathrm{~kg} \mathrm{ha}^{-1}$ ano $^{-1}$ de N, respectivamente para o controle, dose 10 e dose 100 . Essa lixiviação para as doses de 10 e 100 representou $25 \%$ e $10 \%$ do $\mathrm{N}$ aplicado, respectivamente. Segundo os autores, o N remanescente no solo e as perdas gasosas por denitrificação e volatilização da amônia foram provavelmente insignificantes.

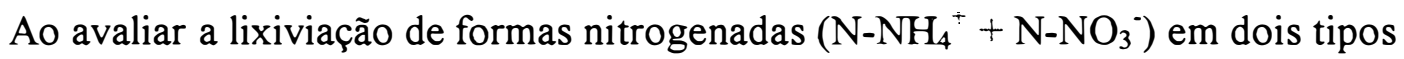
de solos, AQ e LR, após a aplicação de doses crescentes de biossólido (0, 13,5, 29,7 e 40,5 $\mathrm{Mg} \mathrm{ha}^{-1}$, base seca), Oliveira (1995) observou que a lixiviação das formas nitrogenadas aumentaram com as doses aplicadas de biossólido, embora não tivesse observado uma proporcionalidade entre aumento das doses e quantidades lixiviadas. $\mathrm{Na}$ $\mathrm{AQ}$ as perdas de $\mathrm{N}-\mathrm{NH}_{4}{ }^{+}+\mathrm{N}^{-} \mathrm{NO}_{3}{ }^{-}$ocorreram em maiores quantidades sugerindo que, nesse solo, a adição de elevadas quantidades deste resíduo orgânico pode representar riscos ao ambiente.

Shepherd (1996), estudando os fatores que afetam a lixiviação de nitrato em solos agrícolas tratados com biossólidos, constatou que o tipo de biossólido, época de aplicação e o método de aplicação influenciaram a lixiviação. Os riscos de lixiviação geralmente aumentaram na seguinte ordem: lodo tratado líquido injetado > lodo tratado líquido aplicado na superfície $>$ lodo não tratado líquido $>$ torta de lodo desidratada. $\mathrm{O}$ autor observou tendências similares na lixiviação de $\mathrm{N}^{-} \mathrm{NO}_{3}{ }^{-}$nos anos agrícolas de 1991/1992 e 1992/1993, porém as perdas por lixiviação foram maiores no primeiro ano agrícola, apesar da maior precipitação no segundo inverno. Segundo o autor, no segundo 
ano agrícola, o $\mathrm{N}$ pode ter sido perdido por rotas alternativas, particularmente pela denitrificação. O lodo tratado líquido, com uma maior proporção de seu conteúdo de $\mathrm{N}$ na forma amoniacal, apresentou os maiores riscos de lixiviação, enquanto que as menores perdas ocorreram no lodo não tratado líquido e torta de lodo desidratada. $O$ cultivo de cevada após a aplicação do lodo reduziu um pouco a lixiviação, em relação ao solo descoberto. Com base em seu experimento, Shepherd não aconselha aplicações de lodo tratado no outono em solos agrícolas a renosos.

Também Misselbrook et al. (1996) observaram que o tipo de biossólido, época e modo de aplicação do biossólido e o clima influenciavam o quantidade de nitrato lixiviada em áreas de pastagem. As maiores concentrações de $\mathrm{N}_{-} \mathrm{NO}_{3}{ }^{-}$na água lixiviada foram encontradas no outono, no tratamento em que se aplicou o lodo digerido de forma injetada no solo, na região de menor média de precipitação anual (800 mm), nos dois anos agrícolas. Essas concentrações excederam o limite de $11,3 \mathrm{mg} \mathrm{\textrm {L } ^ { - 1 }}$ de $\mathrm{N}-\mathrm{NO}_{3}{ }^{-}$, estabelecido pela Diretriz da Comunidade Européia para a água potável. Cerca de $24 \%$, $11 \%$ e $6 \%$ do $\mathrm{N}$ total aplicado foi lixiviado dos respectivos tratamentos lodo digerido injetado, lodo digerido aplicado na superfície e lodo não tratado injetado. As aplicações realizadas no outono proporcionaram as maiores perdas por lixiviação do que as aplicações feitas no inverno. As perdas por lixiviação foram maiores no lodo digerido do que no lodo não tratado, quando ambos foram injetados em profundidade.

Estudo em casa de vegetação conduzido por Cox (1995) incorporando diversos tipos de fertilizantes como fonte de $\mathrm{N}$ no substrato de crescimento de Tagetes erecta L. e de híbridos de Impatiens sp., mostrou menor ocorrência de lixiviação de formas nitrogenadas no tratamento que recebeu biossólido peletilizado, quando comparado com os tratamentos que receberam fertilizante solúvel em água e fertilizante com liberação controlada (tempo de liberação de 70 dias).

Cartron \& Weil (1998) conduziram um experimento a campo por dois anos para determinar qual dos métodos de aplicação de biossólido afetava o modelo de distribuição sazonal do $\mathrm{N}$ mineral do solo. A aplicação de biossólido foi realizada de modo a fornecer $157 \mathrm{~kg} \mathrm{ha}^{-1}$ de $\mathrm{N}$ disponível a planta, determinado de acordo com a regulamentação do Estado de Mayland, EUA. Os dados mostram que nos dois anos 
agrícolas, ao se comparar os tratamentos biossólido incorporado superficialmente e injetado, as maiores perdas de $\mathrm{N}_{-} \mathrm{NO}_{3}{ }^{-}$por lixiviação ocorrem antes do período de rápida absorção de $\mathrm{N}$ pelas plantas no tratamento em que se incorporou o biossólido. A liberação do $\mathrm{N}_{-} \mathrm{NO}_{3}{ }^{-}$demorou mais, pelo menos um mês, no tratamento em que se injetou o biossólido no solo.

Ao avaliar o status de $\mathrm{N}-\mathrm{NO}_{3}{ }^{-}$em duas áreas agrícolas de escala comercial, uma com um histórico de aplicação de biossólido e outra tendo sido fertilizada somente com produtos inorgânicos comerciais, Artiola (1998) verificou que as perdas por lixiviação de $\mathrm{N}_{-} \mathrm{NO}_{3}{ }^{-}$estimadas foram muito maiores nas áreas onde se aplicou o biossólido do que nas áreas que receberam fertilizante. Conforme o autor, as significantes perdas por lixiviação nas aréas onde se aplicou biossólido foram resultantes das acumulações residuais de biossólido ano a ano que mineralizam e liberam $\mathrm{N}_{-}-\mathrm{NO}_{3}{ }^{-}$na zona de incorporação $(0-30 \mathrm{~cm})$.

\subsubsection{Fitodisponibilidade de metais pesados em solos tratados com biossólidos}

Os metais adicionados ao solo através da aplicação de biossólidos apresentam limitado movimento em profundidade, permanecendo geralmente no horizonte A (Rappaport et al., 1988). Dessa forma, grandes ou repetidas aplicações de biossólido contribuem para o aumento da quantidade de metais lábeis na camada arável.

Algumas pesquisas mostram elevação na absorção de metais pelas culturas ao se aumentar a dose de biossólido aplicada.

Após aplicar 0, 22, 45 e $90 \mathrm{Mg} \mathrm{ha}^{-1}$ de biossólido, base seca, em um solo franco siltoso e cultivar milho (Zea mays L.), Ritter \& Eastbum (1978) constataram concentrações normais de $\mathrm{Cd}$ e $\mathrm{Cr}$ nos grãos de milho e nos colmos $\left(<0,5 \mathrm{mg} \mathrm{kg}^{-1} \mathrm{de} \mathrm{Cd}\right.$ nos grãos e colmos, $<1,0 \mathrm{mg} \mathrm{kg}^{-1}$ de $\mathrm{Cr}$ no grão e de $<1,0-2,0 \mathrm{mg} \mathrm{kg}^{-1}$ de $\mathrm{Cr}$ nos colmos). As concentrações de $\mathrm{Pb}$ nos colmos aumentaram com as doses crescentes de biossólido, variando de $29,4 \mathrm{mg} \mathrm{kg}^{-1}$ na testemunha e $57,9 \mathrm{mg} \mathrm{kg}^{-1}$ na dose de $90 \mathrm{Mg}$ $\mathrm{ha}^{-1}$ de biossólido, porém os autores atribuem estes altos teores de $\mathrm{Pb}$ ao movimento de 
automóveis na área experimental. De acordo com os autores, as concentrações de $\mathrm{Cu}$, $\mathrm{Fe}, \mathrm{Mn}$ e $\mathrm{Zn}$ (respectivamente 6-9, 176-195, 47-73 e 24-43 $\mathrm{mg} \mathrm{kg}^{-1}$ ) nos tecidos das folhas da base da espiga, estavam dentro da faixa considerada normal para a cultura do milho.

Estudando, durante um período de seis anos, a disponibilidade de $\mathrm{Cd}$ e $\mathrm{Zn}$ para a cultura de milho (Zea mays L.) após três aplicações anuais de biossólidos em um solo franco siltoso, que totalizou aplicações acumuladas de $0,60,120$ e $180 \mathrm{Mg} \mathrm{ha}^{-1} \mathrm{de}$ biossólido, base seca, Bidwell \& Dowdy (1987) observaram que nos tratamentos que receberam biossólido houve uma maior acumulação anual de $\mathrm{Cd}$ e $\mathrm{Zn}$ nos colmos do que no tratamento controle. As concentrações de $\mathrm{Cr}, \mathrm{Cu}, \mathrm{Ni}$ e $\mathrm{Pb}$ nos colmos e grãos oscilaram anualmente, não sendo explicadas pelo efeito das doses de biossólido. Dos metais analisados nos colmos e grãos, somente o teor de $\mathrm{Cd}$ nos colmos excedeu ao nível de $0,5 \mathrm{mg} \mathrm{kg}^{-1}$, máximo estabelecido pelo National Research Council para a alimentação animal, em todos os tratamentos com biossólido desde o primeiro ano. A absorção de $\mathrm{Cd}$ diminuiu com o passar dos anos em todas as doses de biossólido e foi inversamente correlacionado com o tempo de observação. A absorção do $\mathrm{Zn}$ declinou ligeiramente com o passar do tempo, embora não fosse no mesmo grau observado para o Cd.

Hue et al. (1988) conduziram um experimento em casa de vegetação com três solos mineralogicamente diferentes: Oxissolo manganífero, Vertissolo alcalino e Andossolo derivado de cinzas vulcânicas. Os autores verificaram que as plantas de alface (Lactuca sativa L.) desenvolvidas no Oxissolo manganífero que recebeu calagem apresentavam elevados teores de $\mathrm{Ni}$ e $\mathrm{Mn}$, devido a aplicação de doses crescentes de biossólido desidratado digerido anaerobiamente. Entretanto, somente os teores de Mn atingiram níveis fitotóxicos. Segundo os autores provavelmente isto deva-se a ocorrência de ligantes orgânicos, produzidos pela rápida decomposição da matéria orgânica após a adição do biossólido, que pode ter dissolvido o $\mathrm{Mn}$ da fase sólida e mantido os altos níveis deste elemento na solução pela formação de complexos, independente do $\mathrm{pH}$ do solo. No Vertissolo a fitotoxicidade do Mn manifestou-se apenas com a aplicação de 180 $\mathrm{Mg} \mathrm{ha}{ }^{-1}$. No mesmo trabalho foi verificado que as concentrações de $\mathrm{Cd}$ e $\mathrm{Zn}$ 
aumentaram em função das doses crescentes de biossólido, porém foram independentes do tipo de solo e não chegaram a atingir níveis fitotóxicos.

Ao avaliar a disponibilidade de metais em três solos de texturas distintas (areia franca, franco argiloso e franco siltoso), tratados com doses crescentes biossólido ( 0,42 , $84,126,168$ e $210 \mathrm{Mg} \mathrm{ha}^{-1}$, base seca), Rappaport et al. (1988) constataram que, em alguns casos, a aplicação de biossólido aumentou as concentrações de $\mathrm{Cd}, \mathrm{Cu}, \mathrm{Ni}$ e $\mathrm{Zn}$ nos grãos de milho (Zea mays L.) e/ou nas folhas da base da espiga, entretanto, tais concentrações encontravam-se dentro da faixa considerada adequada. Apesar das aplicações de $\mathrm{Zn} \mathrm{e} \mathrm{Cu}$, via biossólido, excederem o limite estabelecido pelo USEPA, não se verificou fitotoxicidade destes elementos à planta de milho, nos diversos solos estudados.

Em estudo conduzido no campo por Reddy et al. (1989) em um solo franco arenoso foram aplicadas doses $0,25,50$ e $100 \mathrm{Mg} \mathrm{ha}^{-1}$ de biossólido, base seca, incorporadas até a profundidade de $25 \mathrm{~cm}$. Após cultivarem soja [Glycine max (L.) Merr.] e aplicarem novamente as mesmas doses de biossólido, cultivaram milho (Zea mays $\mathrm{L}$.). Os autores constataram que as concentrações de $\mathrm{Cu}$ nas folhas do milho aumentaram linearmente com as doses aplicadas. A relação entre $\mathrm{Cu}$ adicionado, via biossólido, e a concentração de $\mathrm{Cu}$ nos colmos e grãos de milho foi quadrática. A concentração de $\mathrm{Cu}$ nos grãos de milho variou de 1 a $3 \mathrm{mg} \mathrm{kg}^{-1}$, com uma média de aproximadamente $2 \mathrm{mg} \mathrm{kg}^{-1}$. As concentrações de $\mathrm{Cu}$ nas folhas, colmos e grãos de milho diferiram significativamente. A concentração de $\mathrm{Cu}$ nas folhas foi na faixa de $13 \mathrm{e}$ $22 \mathrm{mg} \mathrm{kg}^{-1}$, respectivamente para as doses 0 e $200 \mathrm{Mg} \mathrm{ha}^{-1}$. Esta concentração foi maior do que a encontrada nos colmos (5-8 $\left.\mathrm{mg} \mathrm{kg}^{-1}\right)$ e grãos $\left(1-2 \mathrm{mg} \mathrm{kg}^{-1}\right)$. Conforme os autores, as concentrações de $\mathrm{Cu}$ nos grãos de milho encontravam-se dentro da faixa considerada normal para a cultura. Com relação a concentração de $\mathrm{Zn}$, esta aumentou nas folhas e colmos da planta de milho em função da adição do biossólido, enquanto que a concentração nos grãos não se alterou significativamente com as doses aplicadas. As concentrações de $\mathrm{Zn}$ encontradas nas folhas, colmos e grãos da testemunha das plantas de milho foram respectivamente $30 \mathrm{mg} \mathrm{kg}^{-1}, 27 \mathrm{mg} \mathrm{kg}^{-1}$ e $28 \mathrm{mg} \mathrm{kg}^{-1}$. Entretanto, no tratamento que recebeu $100 \mathrm{Mg} \mathrm{ha}^{-1}$ de biossólido encontraram $45 \mathrm{mg} \mathrm{kg}^{-1}$ de $\mathrm{Zn}$ nas 
folhas de milho e no tratamento que recebeu $200 \mathrm{Mg} \mathrm{ha}^{-1}, 59 \mathrm{mg} \mathrm{kg}^{-1}$ nos colmos e 25 $\mathrm{mg} \mathrm{kg}^{-1}$ nos grãos. Segundo os autores, estas observações indicam que as folhas e os colmos têm tendência a acumular maior quantidade de $\mathrm{Zn}$ oriundo do biossólido. Também comentaram que as concentrações de $\mathrm{Zn}$ encontradas nos grãos de milho encontravam-se dentro da faixa considerada normal para a cultura.

Boaretto et al. (1992) encontraram teores de $7,2 \mathrm{mg} \mathrm{kg}^{-1}$ de Ni nos grãos de feijão (Phaseolus vulgaris) com aplicações acima de $10 \mathrm{Mg} \mathrm{ha}^{-1}$ de biossólido, enquanto que Wang et al. (1997), com aplicação de $60 \mathrm{Mg} \mathrm{ha}^{-1}$, encontraram acúmulo de $\mathrm{Ni}$ em maior quantidade nas folhas de plantas de trigo (Triticum aestivum), seguido de acúmulo menor nas sementes.

Trabalhando com sorgo [Sorghum bicolor (L.) Moench], André et al. (1994) observaram que as plantas que receberam $64 \mathrm{Mg} \mathrm{ha}^{-1}$ de biossólido apresentaram maiores teores de $\mathrm{Cu}, \mathrm{Pb}, \mathrm{Zn}$ e $\mathrm{Cr}$, sendo que apenas o $\mathrm{Cr}$ diferiu significantemente da testemunha, indicando que o biossólido contribuiu para aumentar este metal nos grãos de sorgo.

Em estudo conduzido por Oliveira (1995), em dois solos distintos, Areia Quartzosa (AQ) e Latossolo Roxo (LR), foram ajustados dois níveis de $\mathrm{pH}$ 3,9 e 4,9, sendo posteriormente tratados com doses de biossólidos equivalentes a $0,13,5,29,7$ e $40,5 \mathrm{Mg} \mathrm{ha}^{-1}$, base seca. Os resultados mostraram que a adição do biossólido aos solos promoveu o aumento da concentração dos metais $\mathrm{Cd}, \mathrm{Cu}, \mathrm{Cr}$, $\mathrm{Ni}$ e $\mathrm{Zn}$ nos mesmos, entretanto, evidências do aumento da fitodisponibilidade desses metais para a cultura do milho (Zea mays L.) só foram observadas para a maior dose aplicada.

Al-Jaloud et al. (1995), ao avaliar os efeitos da irrigação de águas residuárias sobre a composição mineral da planta de milho (Zea mays L.) e sorgo (Sorghum vulgare), verificaram que as variações na concentração de alguns minerais nas plantas de milho coletadas antes do florescimento foram de: $3,8-5,8 \mathrm{~g} \mathrm{~kg}^{-1}$ para o $\mathrm{Mg} ; 8,1-18,7 \mathrm{~g}$ $\mathrm{kg}^{-1}$ para o $\mathrm{N} ; 190-257 \mathrm{mg} \mathrm{kg}^{-1}$ para o Fe; 3,5-5,6 $\mathrm{mg} \mathrm{kg}^{-1}$ para o $\mathrm{Cu} ; 37,1-44,5 \mathrm{mg} \mathrm{kg}^{-1}$ para o Mn; 21,6-33,6 $\mathrm{mg} \mathrm{kg}^{-1}$ para o $\mathrm{Zn} ; 11,0-45,7 \mathrm{mg} \mathrm{kg}^{-1}$ para o $\mathrm{Pb}$ e 2,5-10,8 $\mathrm{mg} \mathrm{kg}^{-1}$ para o Ni. Também constataram que ocorreu um aumento na concentração de $\mathrm{Mg}, \mathrm{N}$, $\mathrm{Cu}, \mathrm{Mn}$ e $\mathrm{Zn}$ da planta de milho com a elevação da concentração dos respectivos 
elementos na água de irrigação. Segundo os autores, as concentrações de $\mathrm{N}, \mathrm{Cu}$ e $\mathrm{Mn}$ nas plantas de milho foram inferiores à faixa considerada adequada. $\mathrm{O}$ coeficiente de determinação $\left(\mathrm{R}^{2}\right)$ indicou que 82 a $99 \%$ da variabilidade na concentração de $\mathrm{Pb}, \mathrm{Ni}$ e Fe nas plantas de milho era devida a irrigação com águas residuárias.

Ao estudar a fitotoxicidade dos metais pesados em áreas que receberam durante um período de oito anos repetidas aplicações de biossólido (total aplicado durante o período em cada tratamento 0, 240, 690 e $870 \mathrm{Mg} \mathrm{ha}^{-1}$, base seca) Berti \& Jacobs (1996) observaram que os rendimentos de todas as culturas, dentre elas o milho (Zea mays L), foram reduzidas em um ou mais tratamentos com biossólido, devido as concentrações fitotóxicas dos metais, provavelmente $\mathrm{Zn}$ e Ni. A fitotoxicidade continuou depois da última aplicação de biossólido. Através da extração seqüencial constataram que o $\mathrm{Cd}, \mathrm{Ni}$ e $\mathrm{Zn}$ encontravam-se nas frações que eram potencialmente disponíveis a absorção pelas plantas (solúvel em água, trocável e solúvel em ácido). Com relação aos metais $\mathrm{Cu}$ e $\mathrm{Cr}$, as aplicações aumentaram a disponibilidade ambiental destes metais, entretanto em menor extensão. Quanto ao $\mathrm{Pb}$, a disponibilidade parece não ter sido aumentada com as aplicações.

Estudando a absorção de $\mathrm{Cd}, \mathrm{Cr}, \mathrm{Cu}, \mathrm{Ni}, \mathrm{Pb}$ e $\mathrm{Zn}$ pela cultura de milho (Zea mays $\mathrm{L}$.) cultivada em solos tratados com 0,50 e $75 \mathrm{Mg} \mathrm{ha}^{-1}$ de biossólido, Pierrisnard (1996) verificou que após a aplicação deste resíduo o $\mathrm{Zn}$ acumulou-se preferencialmente nos sabugos e folhas, $\mathrm{Pb}$ nos sabugos e colmos, $\mathrm{Cr}$ nos sabugos e grãos, $\mathrm{Cd}$ nos sabugos, grãos e colmos, $\mathrm{Ni}$ e $\mathrm{Cu}$ nos sabugos, grãos e raizes. $\mathrm{O}$ autor também observou que as plantas desenvolvidas nas parcelas onde se aplicou biossólido apresentavam maiores teores de $\mathrm{Cu}$ e $\mathrm{Cr}$, enquanto que as desenvolvidas na parcela testemunha apresentavam maiores teores foliares de $\mathrm{Cd}$ e $\mathrm{Ni}$. As plantas de milho das parcelas tratadas com biossólido, quando comparadas com as da parcela testemunha, apresentaram um acúmulo total de $\mathrm{Cd}, \mathrm{Zn}$ e Ni desprezível.

Em estudo conduzido no campo por Logan et al. (1997) em um solo franco argiloso, foram aplicadas doses $0,7,5,15,30,60,90,120,150,188,225$ e 300 $\mathrm{Mg} \mathrm{ha}^{-1}$ de biossólido, base seca, incorporadas até a profundidade de $15 \mathrm{~cm}$ e cultivadas duas culturas, milho (Zea mays $\mathrm{L}$.) e alface (Lactuca sativa $\mathrm{L}$.). Os resultados mostraram 
que nas folhas da base da espiga da cultura do milho as concentrações de $\mathrm{Cd}, \mathrm{Cu}$ e $\mathrm{Zn}$ aumentaram significativamente com as doses aplicadas, enquanto que os teores de $\mathrm{Ni}$ e $\mathrm{Pb}$ foram menores do que os do controle. Essas concentrações exibiram um resposta tipo platô, que pode ser modelada com a equação de Mitscherlich. $\mathrm{Na}$ alface, as concentrações de $\mathrm{Cd}, \mathrm{Cu}$ e $\mathrm{Zn}$ aumentaram linearmente com as doses de biossólido, em todos os anos de avaliação. Entretanto, ao analisar as curvas de regressão com o tempo de avaliação, verificaram que após os dois primeiros anos de avaliação as curvas de regressão geralmente declinavam e estabilizavam.

No que se refere a fitodisponibilidade dos metais pesado, é importante ressaltar que tem sido propostas duas hipóteses para descrever a fitodisponibilidade de metais potencialmente tóxicos em solos tratados com biossólidos.

A teoria platô (plateau theory) argumenta que a capacidade de adsorção do metal adicionado com o biossólido persiste enquanto o metal persistir no solo e os metais permaneceriam em formas químicas não prontamente disponíveis para a absorção pelas plantas. Por isso, as concentrações de metais nos tecidos das plantas atingiriam um platô com aumento das aplicações de biossólido e permaneceriam neste platô após o término das aplicações (Chang et al. 1997). A teoria platô sugere que o biossólido é tanto uma fonte quanto um sumidouro para os metais pesados aplicados ao solo. Aplicando-se baixas doses de biossólido no solo, os metais predominariam adsorvidos ao solo e a planta, de um modo geral, aumentaria a absorção de forma linear. Aplicandose doses muito altas desse resíduo, a matriz do biossólido passaria a exercer uma influência sobre os metais adsorvidos no solo. Em um certo limite, com a matriz do solo aproximada da matriz do biossólido puro, a absorção dos metais seria procedente essencialmente do biossólido puro, sendo determinada pela adsorção de cada metal com a matriz do biossólido (Logan et al. 1997). De acordo com Logan et al. (1997) há fatores confusos na teoria platô no que diz respeito a decomposição da matéria orgânica do biossólido e os efeitos do biossólido sobre o pH do solo.

A hipótese bomba relógio (time bomb) postula que a capacidade de adsorção do metal no solo é aumentada pela adição da matéria orgânica no solo com o biossólido. Esta capacidade, entretanto, reverte-se ao seu nível de base original após o término das 
aplicações de biossólido com a mineralização da matéria orgânica liberando metais de formas mais solúveis (Chang et al. 1997). Esta suposição assume que o biossólido é na sua maior parte orgânico e que os metais estão primordialmente ligados a matéria orgânica do biossólido. De fato, o biossólido apresenta cerca de 60\% de matéria orgânica em peso, o restante se constitui de uma variedade de sólidos inorgânicos e de uma pequena percentagem de íons complexados organicamente. Alguns dos metais serão co-precipitados com esta fração inorgânica que não será diretamente afetada pela decomposição da matéria orgânica, porém será indiretamente afetada se houver uma diminuição do pH do solo (Logan et al. 1997).

\subsubsection{Fatores que governam a disponibilidade de metais pesados às plantas}

A extensão da contaminação dos solos e das águas por metais pesados e sua entrada na cadeia alimentar vai depender da concentração do metal no biossólido, da dose de aplicação do biossólido, das propriedades do solo, como pH, CTC, teor de óxidos de $\mathrm{Fe}, \mathrm{Al}$ e $\mathrm{Mn}$, teor de matéria orgânica, potencial redox, atividade biológica, bem como do genótipo das plantas, pois sabe-se que algumas plantas têm tendência a acumular metais pesados, enquanto outras têm pouca afinidade para absorver tais elementos (Hue et al., 1988; Petruzzelli, 1989; Amaral Sobrinho \& Velloso, 1993; Ainsworth et al., 1994; Gambrell, 1994; Sing \& Steinnes, 1994, Mattiazzo-Prezotto, 1994). Os fatores ambientais, tais como temperatura do solo e condições de umidade, também influenciam significativamente a disponibilidade dos metais. Esta disponibilidade tende a ser menor em temperaturas e níveis de umidade menores (Petruzzelli, 1989).

Com relação as doses de aplicação de biossólidos, estudos de Chang et al. (1984) indicam que embora a absorção de metais pesados pelas culturas aumente com as doses de aplicação deste resíduo, a quantidade total absorvida de metais é menor do que a quantidade introduzida pela aplicação de biossólido, sendo inferior a $1 \%$.

Logan \& Chaney (1983) comentam que o pH do solo é um dos fatores mais 
importantes no controle da biodisponibilidade de metais. Com exceção do Mo e do Se, todos os demais metais são mais lábeis em pH baixo, devido a ocorrência de espécies hidrolisadas de hidróxidos e a solubilidade de outras fases minerais sólidas, tais como carbonatos e fosfatos. Em pH elevado, de acordo com Petruzzelli (1989), a disponibilidade dos metais tende a ser menor, devido a formação de precipitados, adsorção muito forte e ao aumento da estabilidade de complexos com substâncias húmicas. Segundo Jing \& Logan (1992) a absorção de Cd pelas plantas é controlada em parte pela química deste elemento no biossólido e especificamente pelo seu conteúdo no biossólido, também comentam que os principais fatores relacionados com a absorção desse elemento são a dose de aplicação, $\mathrm{pH}$ do solo e as espécies de plantas.

Quanto a CTC, verifica-se que as cargas negativas que ocorrem nos mineriais de argila e na matéria orgânica atraem os cátions por forças eletrostáticas, sendo altamente influenciada pelo $\mathrm{pH}$ do solo. Leeper ${ }^{1}$ (1972), citado por Logan \& Chaney (1983), foi o primeiro a sugerir que a CTC do solo fosse utilizada como um indicador da quantidade de metais $(\mathrm{Cu}, \mathrm{Ni}, \mathrm{Zn})$ que seguramente poderia ser adicionada ao solo sem ocasionar fitotoxicidade. Ao estudar a aplicação de diferentes resíduos orgânicos ao solo, dentre os quais o biossólido, Barretto (1995) verificou que houve alteração da CTC a pH 7, principalmente, em função das mudanças no $\mathrm{pH}$ do solo. A alteração da CTC determinada com soluções não tamponadas apenas ocorreu em solo arenoso. $\mathrm{O}$ autor também comenta que a CTC e a capacidade de retenção de água, como parâmetros de caracterização de resíduos orgânicos, não são suficientes para prever comportamentos resultantes da sua adição ao solo quanto a estes atributos.

Embora a CTC seja importante no controle da toxicidade de metais pesados adicionado ao solo na forma de sais, há pouca evidência para suportar que a CTC controle a disponibilidade de metais em solos que recebem aplicação de biossólidos. De acordo com Welch \& Lund (1987) é dificil mostrar uma relação direta entre a CTC e a absorção pela planta de metais pesados oriundos da aplicação de biossólido, porque,

\footnotetext{
${ }^{1}$ LEEPER, G.W. Reactions of heavy metals with soils with special regard to their application in sewage wastes. Dept. of the Army, Corps of Engineers, contract $\mathrm{N}^{\circ}$. DACW 73-73-C-0026. 70 p. citado por LOGAN, T.J.; CHANEY, R.L. Metals. In: WORKSHOP ON UTILIZATION OF MUNICIPAL WASTERWATER AND SLUDGE ON LAND (1983 : Riverside). Proceedings. Riverside :
} 
ambas, são afetadas pelo $\mathrm{pH}$, teor de matéria orgânica, tipo de argila, óxidos de Fe e Mn, e outras propriedades tanto do solo quanto do biossólido aplicado. Estes fatores podem ser mais importantes que a CTC e devem ser considerados quando adições de metais ao solo são estabelecidas. Ao estudar alguns parâmetros para a adição de resíduos contendo metais a solos sob condições tropicais, Mattiazzo-Prezotto (1994) sugeriram que a quantidade máxima de metais permissíveis a ser adicionada nesses solos, via resíduos, pode ser limitada além da CTC e $\mathrm{pH}$, também pelo conteúdo de argila e óxidos de $\mathrm{Fe}$ e Al do solo.

Os óxidos de $\mathrm{Fe}, \mathrm{Al}$ e $\mathrm{Mn}$ são componentes do solo que desempenham papel importante na imobilização de metais pesados. Os cátions podem ser adsorvidos eletrostaticamente na superficie dos óxidos ou especificamente, formando ligações covalentes com o oxigênio e a hidroxila. Pode ocorrer, também, que os íons inicialmente adsorvidos sejam, mais tarde, incorporados dentro da estrutura do mineral, após ocorrer os processos de penetração, recristalização e difusão dentro dos poros. Ainsworth et al. (1994) verificaram que o Co e o Cd poderiam ser incorporados dentro da estrutura de óxidos metálicos através da recristalização, enquanto que o $\mathrm{Pb}$ permaneceu adsorvido superficialmente. A primeira tentativa de estabelecimento de critérios para a aplicação de resíduos, contendo metais, a solos sob clima tropical foi sugerida por MattiazzoPrezzotto (1994) ao trabalhar com sais solúveis como fonte de metais. De acordo com o autor, os conteúdos de argila e de óxidos de $\mathrm{Fe}$ e $\mathrm{Al}$ devem ser considerados. Solos com conteúdo de argila inferior a $7 \%$ e conteúdo de óxidos de Fe e Al inferior a 3\% são inadequados para a aplicação de resíduos contendo metais. Estudando as formas de Cd em solos arenosos, Mann \& Ritche (1995) observaram que a disponibilidade de $\mathrm{Cd}$ às plantas, nestes solos, poderia ser reduzida com a adição de terras contendo altas quantidades de óxidos-hidróxidos e matéria orgânica.

Muitos aspectos da química dos metais pesados no solo estão relacionados com a formação de complexos com a matéria orgânica. Enquanto os metais monovalentes $\left(\mathrm{Na}^{+}, \mathrm{K}^{+}\right.$e outros) são retidos principalmente como simples cátions trocáveis, através da formação de sais com os grupos $\mathrm{COOH}$, os cátions polivalentes $\left(\mathrm{Cu}^{2+}, \mathrm{Zn}^{2+}, \mathrm{Mn}^{2+}, \mathrm{Co}^{2+}\right.$ 
e outros) têm o potencial de formar ligações coordenadas com moléculas orgânicas. Sob certas circunstâncias a concentração de um íon metálico pode ser reduzida ao nível não tóxico através da complexação. Isto ocorre quando o complexo orgânico metálico tem alta estabilidade, tal como complexos de ácido húmico e outros componentes da matéria orgânica de alto peso molecular. Os complexos metálicos com ácidos fúlvicos são mais solúveis do que os com ácidos húmicos, porque apresentam alta acidez e pesos moleculares relativamente baixos (Stevenson, 1982).

Com relação ao potencial redox, Petruzzelli (1989) relata que com a diminuição do potencial redox do solo pode ocorrer aumentos na disponibilidade dos metais, devido a dissolução de alguns óxidos que apresentam metais, tais como o $\mathrm{Cu}$ e $\mathrm{Zn}$, oclusos. Porém, em decréscimos muito grandes, ou seja, em valores muito baixos de potencial redox há a formação de sulfitos insolúveis que tornam estes elementos indisponíveis.

Miyazawa et al. (1996) comentam que os metais pesados, tais como $\mathrm{Ba}, \mathrm{Cd}, \mathrm{Co}$, $\mathrm{Cr}, \mathrm{Cu}, \mathrm{Ni}, \mathrm{Pb}, \mathrm{Zn}$ e outros, presentes no biossólido, sofrem várias reações químicas. As principais são: adsorção na superficie das argilas; complexação com ácidos húmicos, fúlvicos, ligantes orgânicos e inorgânicos; precipitação como carbonatos, hidróxidos, óxidos, sulfetos; oxidação e redução. O equilíbrio químico destas reações define a disponibilidade e toxidez para as plantas, solubilidade e lixiviação de um metal do solo.

2.2.3.2 Utilização de extratores para a avaliação da fitodisponibilidade de metais pesados em solos tratados com biossólidos

A reciclagem agrícola de biossólidos cria uma demanda por informações sobre a adequação dos extratores químicos em predizer a disponibilidade dos metais pesados para as plantas.

A extração com um simples reagente ajuda diretamente na determinação de formas disponíveis para as plantas, onde nestes termos pode se referir não somente aos metais presentes na forma de íons simples ou complexos na solução do solo, íons trocáveis ou íons ligados a substâncias orgânicas, mas também àqueles metais que 
poderão participar de processos nutricionais devido a alteração lenta do solo (Petruzzelli, 1989).

Segundo Lake et al. (1984), apesar da natureza não específica dos métodos de extração química, sua simplicidade e rapidez operacional faz com que sejam os mais adequados para avaliação da disponibilidade de metais sob condições de campo.

Para a avaliação da fitodisponibilidade de metais pesados têm sido utilizado diversos tipos de extratores químicos, tentando correlacionar as quantidades extraídas e as absorvidas pelas plantas. Dentre eles os mais comumente utilizados são: (a) soluções aquosas em diversas razões de concentração com o solo; (b) soluções de concentrações variáveis de metais alcalinos e alcalinos terrosos, que extraem as quantidades trocáveis de metais pesados; (c) agentes complexantes, tais como ácido etileno diamino tetracético (EDTA), ácido dietileno triamino pentacético (DTPA), ácido nitrilo acético (NTA), etc., que podem também liberar os metais complexados ou adsorvidos por substâncias orgânicas, além de simular o comportamento dos exudatos da raiz; (d) misturas dos extratores acima mencionados (Petruzzelli, 1989).

A utilização de água possibilita extrair quantidades extremamente pequenas de metais e geralmente somente o manejo de técnicas analíticas mais refinadas permitem detectar tais concentrações (Petruzzelli, 1989).

Alguns pesquisadores utilizam soluções de sais neutros, tais como $\mathrm{NaNO}_{3}$ $0,1 \mathrm{~mol} \mathrm{~L}^{-1}, \mathrm{Ca}\left(\mathrm{NO}_{3}\right)_{2}, \mathrm{MgCl}_{2} 1 \mathrm{~mol} \mathrm{~L}^{-1} \mathrm{em} \mathrm{pH} 7, \mathrm{CaCl}_{2} 0,05 \mathrm{~mol} \mathrm{~L}^{-1}$ ou $\mathrm{KNO}_{3} 1 \mathrm{~mol} \mathrm{~L}$ ${ }^{1}$, para determinar as frações trocáveis de metais, sendo que a eficiência desses extratores depende da força iônica, que é função da molaridade da solução (Keller \& Védy, 1994; Barretto, 1995; Oliveira, 1995). De acordo com Petruzzelli (1989), as quantidades de metais extraídas por estas soluções variam, em solos tratados com resíduos, de menos de $1 \%$ do total a cerca de $20 \%$, particularmente no caso do $\mathrm{Cd}$.

Em estudos de fitodisponibilidade em áreas que recebem biossólidos têm sido muito utilizados os extratores ácidos, principalmente Mehlich $1\left(\mathrm{H}_{2} \mathrm{SO}_{4} 0,025 \mathrm{~mol} \mathrm{~L}^{-1}+\right.$ $\left.\mathrm{HCl} 0,025 \mathrm{~mol} \mathrm{~L}^{-1}\right)$, Mehlich $3\left(\mathrm{CH}_{3} \mathrm{COOH} 0,2 \mathrm{~mol} \mathrm{~L}^{-1}+\mathrm{NH}_{4} \mathrm{NO}_{3} 0,25 \mathrm{~mol} \mathrm{~L}^{-1}+\mathrm{NH}_{4} \mathrm{~F}\right.$

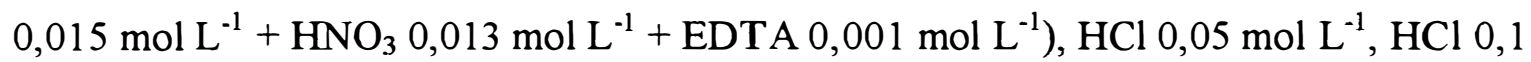
$\mathrm{mol} \mathrm{L}^{-1}$ e $\mathrm{HNO}_{3}$ (Singh et al. 1994; Korcak \& Fanning, 1978; Barretto, 1995; Oliveira, 
1995; Bertoncini, 1997). As quantidades de metais absorvidas por vegetais muitas vezes correlacionam-se com os determinados nestas soluções, embora alguns desses extratores possam extrair quantidades próximas do total aplicado ao solo (Barretto, 1995). O uso de ácidos mais ou menos diluídos tira proveito do aumento da mobilidade dos metais, devido a diminuição do $\mathrm{pH}$, de modo a correlacioná-lo com a quantidade disponivel para a planta. Também nestes casos, a natureza química diferente dos metais acentua significativamente as diferenças de comportamento, por exemplo o $\mathrm{Zn}$ e o $\mathrm{Cu}$ tem uma mobilidade semelhante com a variação do $\mathrm{pH}$, diferente da mobilidade do $\mathrm{Cu}$ e $\mathrm{Pb}$, que por sua vez são diferentes daquela do Co e Ni (Petruzzelli, 1989).

Sims et al. (1991), comparando três extratores diferentes (Mehlich 1, Mehlich 3 e DTPA) e o método EPA $3050\left(\mathrm{HNO}_{3}-1: 1\right)$, que determina os teores totais de metais, em cinco solos que haviam recebido biossólidos nos últimos três anos, observaram que os extratores removeram menos de $30 \%$ do teor total de metais da maioria dos solos, com percentagens médias de $15 \%, 32 \%$ e $11 \%$ para o Mehlich 1 , Mehlich 3 e DTPA, respectivamente. Correlações estatisticamente significativas foram obtidas entre o teores totais de metais (método EPA 3050) e os três extratores para o $\mathrm{Cu}, \mathrm{Pb}$ e $\mathrm{Zn}$, porém não para o $\mathrm{Cd}$ e Ni. O Mehlich 1 foi o extrator que melhor se correlacionou com os teores totais de $\mathrm{Cu}$ e $\mathrm{Zn}\left(\mathrm{r}=0,78^{* *}, 0,60^{* *}\right.$, respectivamente), enquanto que os extratores com agentes quelantes (DTPA e Mehlich 3) melhor se correlacionaram com os teores totais de $\mathrm{Pb}\left(\mathrm{r}=0,85^{* *}, 0,63^{* *}\right.$, respectivamente $)$.

Ao testar diversos métodos de extração para teores solúveis e totais de $\mathrm{Cd}, \mathrm{Cr}$, $\mathrm{Cu}$, Ni e $\mathrm{Zn}$ em três solos diferentes, Areia Quartzosa (AQ), Latossolo Vermelho Escuro (LE) e Latossolo Vermelho Amarelo (LV) tratados com biossólidos, Bertoncini (1997) constatou que na determinação de teores solúveis de metais o extrator $\mathrm{HCl} 0,1 \mathrm{~mol} \mathrm{~L}^{-1}$ mostrou-se mais eficiente que os extratores Mehlich-3 e DTPA $0,005 \mathrm{~mol} \mathrm{~L}^{-1} \mathrm{pH} 7,3$, exceto para o $\mathrm{Cu}$ nos tratamentos $\mathrm{LV}+$ lodo (Mehlich-3 foi melhor extrator) e LE+lodo (DTPA não diferiu de $\mathrm{HCl} 0,1 \mathrm{~mol} \mathrm{~L}^{-1}$ ). Os extratores Mehlich-3 (solubilizante e complexante) e DTPA (complexante) indicados para a extração de $\mathrm{Cd}, \mathrm{Cr}, \mathrm{Cu}$ e $\mathrm{Ni}$ e $\mathrm{Cu}$ e $\mathrm{Zn}$, respectivamente, não suplantaram a extração de metais com $\mathrm{HCl} 0,1 \mathrm{~mol} \mathrm{~L}^{-1}$ na maioria dos solos tratados ou não com biossólido. 
$\mathrm{O}$ uso de agentes quelantes (EDTA e DTPA) decorre da sua habilidade de deslocar metais ligados a radicais orgânicos. A extração com DTPA foi desenvolvida por Lindsay \& Norvell (1978) inicialmente para se identificar solos caicários e próximos da neutralidade com deficiência de $\mathrm{Zn}, \mathrm{Fe}, \mathrm{Mn}$, e $\mathrm{Cu}$. Posteriormente esse extrator passou a ser utilizado em diversos trabalhos para extrair outros metais além destes e em variados tipos de solos tratados com biossólidos (Korcak \& Fanning, 1978; Baxter et al., 1983; Singh et al., 1994; Barretto, 1995; Oliveira, 1995; Bertoncini, 1997).

Rappaport et al. (1988), ao trabalhar com três solos de classes texturais distintas (areia franca, franco argiloso e franco siltoso) e aplicar doses crescente de biossólido (0$210 \mathrm{Mg} \mathrm{ha}^{-1}$, base seca, variando cada dose de 42 unidades), não constataram relação significativa entre os teores de $\mathrm{Cd}, \mathrm{Cu}, \mathrm{Ni}$ e $\mathrm{Zn}$ extraídos com DTPA e as respectivas concentrações dos metais nas folhas da base da espiga do milho nos três solos estudados. Os autores observaram que as quantidades de $\mathrm{Cd}, \mathrm{Cu}, \mathrm{Ni}$ e $\mathrm{Zn}$ extraídas com DTPA no horizonte Ap dos três solos aumentou linearmente $\left(R^{2}=0,76^{* *}\right.$ a $\left.0,88^{* *}\right)$ com as doses de biossólido aplicadas. Os teores máximos de metais extraídos com DTPA nos solos foi de $0,6 \mathrm{mg} \mathrm{kg}^{-1}$ para o $\mathrm{Cd}, 150 \mathrm{mg} \mathrm{kg}^{-1}$ para o $\mathrm{Cu}, 4,0 \mathrm{mg} \mathrm{kg}^{-1}$ para o $\mathrm{Ni}, 75 \mathrm{mg} \mathrm{kg}^{-1}$ para o $\mathrm{Zn}$. A ordem de concentração dos metais no solo extraídos com DTPA foi $\mathrm{Cu}>\mathrm{Zn}>\mathrm{Ni}$ $>\mathrm{Cd}$, o que correspondeu as quantidades aplicadas via biossólido.

Em estudo conduzido em solo calcário franco arenoso, onde aplicou-se doses de biossólidos equivalentes a 400, 800 e $1200 \mathrm{~kg} \mathrm{ha}^{-1}$ ano $^{-1}$ de N em cultivos seqüenciais de batata-milho, batata-alface e batata, no primeiro, segundo e terceiro ano, respectivamente, Roca \& Pomares (1991) também verificaram que a concentração de metais nas folhas de milho não se correlacionou com os metais extraídos do solo pelos diversos extratores, porém obtiveram correlações significativas entre os níveis de $\mathrm{Pb}$ no solo e níveis do metal nos grãos do milho com EDTA-pH 4,65, EDTA-pH 8,6, Bicarbonato de amônio-DTPA, DTPA e água régia, Ni extraído por EDTA-pH 8,6 e Cd extraído por $\mathrm{HCl} 0,1 \mathrm{~mol} \mathrm{~L}^{-1}$.

Todavia, Bidwell \& Dowdy (1987) após três aplicações anuais de biossólido que totalizaram $0,60,120$ e $180 \mathrm{Mg} \mathrm{ha}^{-1}$, base seca, em um solo franco siltoso, constataram que as concentrações de $\mathrm{Cd}\left(0,08-6,76 \mathrm{mg} \mathrm{kg}^{-1}\right)$ e $\mathrm{Zn}\left(1,1-61,3 \mathrm{mg} \mathrm{kg}^{-1}\right)$ extraídas do 
solo pelo DTPA foram altamente correlacionadas com a absorção do milho (Zea mays L.) dentro de quatro dos seis anos de avaliação. Contudo, os autores ressaltam que a avaliação da fitodisponibilidade, principalmente do Cd, pelo extrator DTPÁ, em cultivos subseqüentes, é questionável, pois constataram, no decorrer do tempo, uma diminuição na absorção deste elemento em niveis constantes de extração. Segundo os autores, este comportamento está relacionado à conversão do $\mathrm{Cd}$ a formas menos disponiveis para a planta, porém que são ainda extraiveis pelo DTPA.

Também Singh \& Narwall (1984) trabalhando com outra cultura, nabo forrageiro (Brassica napus L. 'Kenton'), em solos tratados com biossólidos destacaram o DTPA como melhor extrator, dentre $\mathrm{HNO}_{3}$, água régia, $\mathrm{HCl}, \mathrm{NH}_{4} \mathrm{OAc}(\mathrm{pH} 4,8)$ e $\mathrm{H}_{2} \mathrm{O}$, em predizer a disponibilidade de $\mathrm{Cd}, \mathrm{Pb}$ e possivelmente $\mathrm{Zn}$ no nabo forrageiro sob diversas aplicações de biossólido e pH de solo. Além disso, os autores verificaram que a ordem dos extratores para a maioria dos metais estudados foi a seguinte $\mathrm{HNO}_{3}>$ água régia > $\mathrm{HCl}>\mathrm{NH}_{4} \mathrm{OAc}(\mathrm{pH} 4,8)>\mathrm{DTPA}>\mathrm{H}_{2} \mathrm{O}$, sendo governada pelas doses de biossólido aplicadas, porém pouco afetada pela mudança do $\mathrm{pH}$ do solo.

Resultado semelhante foi obtido por Handreck (1994) que, ao avaliar o efeito do pH sobre a absorção de metais pela plantas de Beta vulgaris cicla 'Fordhook Giant', Phaseolus vulgaris e Agrostis capillaris 'Parys' desenvolvidas em meio constituido por casca de Pinus radiata e de $0-41 \%$ de biossólido seco, verificou ser o extrator DTPA eficiente no estabelecimento da fitotoxicidade do $\mathrm{Cd}$ ou da absorção potencialmente excessiva deste elemento pelas plantas.

Em solo podzólico de textura média com três diferentes níveis de $\mathrm{pH}(5,2,5,8 \mathrm{e}$ 6,4) King \& Hajjar (1990) aplicaram, durante três anos, doses de 0, 9, 18, e $27 \mathrm{Mg} \mathrm{ha}^{-1}$ $a^{-1}$ de biossólido na forma líquida e estudaram o efeito residual deste material nas concentrações de metais das plantas de amendoim (Arachis hypogaea L.) e tabaco (Nicotiana tabacum L.). Os resultados de correlação mostraram que o extrator DTPA$\mathrm{pH}$ 7,3 foi melhor que o Mehlich 3 em predizer as concentrações de $\mathrm{Cd}$, $\mathrm{Cu}, \mathrm{Ni}$ e $\mathrm{Zn}$ nos tecidos das plantas.

Examinando o efeito residual da aplicação de quatro tipos de biossólidos na concentração de metais pesados de dois solos de texturas distintas, franco siltosa e 
franco arenosa, que receberam doses de $0,56,112$, e $224 \mathrm{Mg} \mathrm{ha}^{-1}$, base seca, Mulchi et al. (1991) constataram que, decorridos aproximadamente oitos anos da aplicação, os teores totais de $\mathrm{Zn}, \mathrm{Cu}, \mathrm{Fe}, \mathrm{Pb}, \mathrm{Ni}$ e Cd elevaram-se significativamente $(\mathrm{p} \leq 0,05)$ como aumento das doses, em todos os tipos de biossólido. Para alguns elementos, a ordem dos extratores variou em função do tipo de biossólido. Para o $\mathrm{Zn}$, a ordem foi Mehlich $1>$ Mehlich $3>$ DTPA-pH 7,3 em todos os tipos de biossólido e doses. Para o $\mathrm{Cu}$, a ordem foi Mehlich $3>$ Mehlich $1>$ DTPA-pH 7,3 para os solos tratados com biossólido digerido desidratado e biossólido digerido alcalinizado, porém Mehlich $1 \geq$ DTPA-pH 7,3 > Mehlich 3 para os solos onde se aplicou composto de biossólido alcalinizado e biossólido tratado com $\mathrm{Fe}$ e aquecimento. Com relação a extração de $\mathrm{Mn}$, a ordem dos extratores foi Mehlich $1>$ Mehlich $3 \geq$ DTPA-pH 7,3 nos solos que receberam composto de biossólido alcalinizado e biossólido tratado com $\mathrm{Fe}$ e aquecimento, porém para os solos com biossólido digerido desidratado e biossólido digerido alcalinizado foi Mehlich $3>$ Mehlich $1>$ DTPA-pH 7,3. A ordem dos extratores para o $\mathrm{Fe}, \mathrm{Ni}, \mathrm{Pb}$, e Cd foi quase semelhante em todos os tipos de biossólido. Os autores obtiveram correlações significativamente altas e positivas entre os teores de $\mathrm{Zn}, \mathrm{Cu}, \mathrm{Ni}$ e $\mathrm{Cd}$ encontrados na folha de tabaco e os teores extraídos com os três extratores. Para o Mn houve correlação significativamente positiva para os extratores DTPA-pH 7,3 e Mehlich 1. Para o Fe e Pb não houve correlação significativa. Os autores concluíram que tanto o DTPA-pH 7,3 quanto o Mehlich 1 poderiam ser utilizados como extratores nos solos tratados com biossólido da região estudada (Planície Costeira dos E.U.A.).

Ao avaliar a relação entre as concentrações de $\mathrm{Cd}, \mathrm{Cu}, \mathrm{Zn}$ de diversas culturas e as propriedades do solo de locais que durante longo tempo receberam aplicação de biossólidos, Miner et al. (1997) observaram que as quantidades de $\mathrm{Cd}, \mathrm{Cu}$ e $\mathrm{Zn}$ recuperadas pelos extratores utilizados obedeceram a seguinte ordem: Mehlich $3>$ EDTA $0,05 \mathrm{~mol} \mathrm{~L}^{-1}>$ DTPA $0,05 \mathrm{~mol} \mathrm{~L}^{-1}$. Os modelos de regressão linear simples que descreveram as concentrações de metais na beterraba açucareira (Beta vulgaris L.), alface (Lactuca sativa L.), tabaco (Nicotina tabacum L.) e amendoim (Arachis hypogea L.) em função destes extratores foram significativos, porém apresentaram coeficiente de determinação $\left(\mathrm{R}^{2}\right)$ relativamente baixo. A inclusão das propriedades do solo, tais como 
$\mathrm{pH}$, conteúdo de argila e carbono orgânico no modelo de regressão multivaridada melhorou o ajuste do modelo, obtendo-se alto $R^{2}$. Os valores de $R^{2}$ variaram de 0,30 a 0,96 , com os menores valores sendo constatados para as culturas de alface e amendoim. Os modelos ajustados para todas as outras combinações cultura-extrator-metal apresentaram $\mathrm{R}^{2}>0,83$. Os extratores foram altamente correlacionados entre si, resultando em semelhante eficiência com indicadores das concentrações de metais no solo disponível para as plantas.

A determinação dos teores totais de metais presentes no solo visa a obtenção de dados sobre o acúmulo destes elementos ao longo do tempo. Convencionalmente esta determinação exige digestão com ácido fluorídrico (HF) juntamente com outros ácidos fortes. Contudo, o uso de HF na rotina dos laboratórios não é recomendada, pois este reagente é altamente corrosivo e de dificil manuseio. Por este motivo, a preferência pelo uso de simples ácidos fortes, como $\mathrm{HNO}_{3}$ ou mistura de ácidos, tais como ácidos nítrico e perclórico $\left(\mathrm{HNO}_{3}+\mathrm{HClO}_{4}-5: 1\right)$ ou água régia $\left(\mathrm{HCl}+\mathrm{HNO}_{3}-3: 1\right)$ é muito comum (Abreu et al., 1996). De acordo com Keller \& Védy (1994), a ágıı régia extrai todos os metais presentes na fração residual do solo, exceto àqueles que ocorrem nos silicatos, deste modo a percentagem de extração varia de 60-100\%, dependendo do metal.

Os metais do solo ou do biossólido podem ser extraídos pelo simples aquecimento das amostras com água régia em frascos com condensadores para refluxo ou pelo aquecimento em microondas. Nieuwenhuize et al. (1991), ao comparar os dois métodos de extração em amostras de sedimentos, solos, biossólido e solo tratado com biossólido, verificaram que não havia diferenças significativas entre os dois métodos. Os autores concluíram que o aquecimento em microondas é uma boa alternativa para a extração de $\mathrm{Cd}, \mathrm{Cr}, \mathrm{Cu}, \mathrm{Fe}, \mathrm{Mn}, \mathrm{Pb}$ e $\mathrm{Zn}$ nesses materiais, pois envolve rápida extração em recipientes fechados, com pouco risco de contaminação externa.

Comparando métodos para avaliar os metais pesados em resíduos orgânicos, Abreu et al. (1996) observaram que a extração em microondas com água régia removeu maiores quantidades de metais do material certificado de referência do que o método USEPA-3051 (ácido nítrico) e o procedimento nitro-perclórico convencional, com uma recuperação maior do que $90 \%$ para $\mathrm{Fe}, \mathrm{Mn}, \mathrm{Zn}, \mathrm{Cu}, \mathrm{Pb}$ e $\mathrm{Cd}, 76 \%$ para $\mathrm{Ni}$ e $61 \%$ para 
Cr. Em média, quando comparado com os outros dois métodos, o método de extração com água régia apresentou quantidades significativamente maiores de $\mathrm{Fe}, \mathrm{Mn}, \mathrm{Zn}$ e $\mathrm{Cr}$ para o composto de lixo urbano, biossólido e esterco de porco.

Roca \& Pomares (1991), ao compararem diversos extratores para a avaliação da biodisponibilidade de metais pesados em solos calcários tratados com biossólido, observaram que altas quantidades de metais pesados foram extraídas do solo pela água régia, enquanto que com DTPA foram extraídas baixas quantidades. A adição de biossólido resultou em aumentos significativos de $\mathrm{Zn}$ (nos três anos de avaliação) e de $\mathrm{Cd}$ (no segundo e terceiro ano), extraídos por todos os extratores utilizados (DTPA;

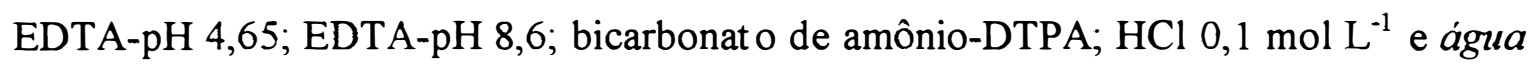
régia), quando comparados com a testemunha. Para o $\mathrm{Ni}$, aumentos significativos dos teores do solo foram detectados por todos os extratores, com exceção da água régia.

Os resultados dos inúmeros trabalhos apresentados parecem ser contraditórios, porém ao se utilizar os extratores químicos para a previsão da fitodisponibilidade devese levar em consideração o metal em estudo, o tipo de solo onde ele está presente, a cultura e o tipo de biossólido gerado pela estação de tratamento de esgoto, pois não existe um único extrator que se correlacione adequadamente com todos os metais, tendo em vista a existência destas variáveis.

Conforme Petruzzelli (1989), apesar da diversidade de métodos de extração, o uso de testes com plantas é essencial para a identificação e avaliação da disponibilidade de metais em solos tratados com resíduos. $O$ autor também ressalta que a extração química não representa um método definitivo de "especiação" analítica, apenas fornece uma idéia aproximada e que os testes com plantas reproduzem parcialmente as situações completas de teste de campo, porém ambos separadamente ou em conjunto podem ajudar significantemente na avaliação do nível de perigo dos metais pesados, tanto por parte dos técnicos, como também dos legisladores, permitindo a identificação das diferenças entre a quantidade total e a quantidade de metais que pode ser biodisponível no solo.

A Tabela 1 apresenta, resumidamente, os métodos de extração e os respectivos metais mais comumente removidos de solos tratados com biossólidos. 
Tabela 1. Métodos de extração utilizados para remoção de metais pesados em solos tratados com biossólido.

\begin{tabular}{|c|c|c|}
\hline Métodos de extração & Metais & Fonte \\
\hline Água régia & $\begin{array}{l}\mathrm{Cd}, \mathrm{Cr}, \mathrm{Cu}, \mathrm{Fe}, \mathrm{Mn}, \mathrm{Pb} \\
\mathrm{Zn}\end{array}$ & $\begin{array}{l}\text { Nieuwenhuize et al. (1991); Roca \& Pomares } \\
\text { (1991). }\end{array}$ \\
\hline Bicarbonato de amônio-DTPA & $\mathrm{Pb}$ & Roca \& Pomares (1991) \\
\hline DTPA-pH 7,3 & $\mathrm{Cd}, \mathrm{Cu}, \mathrm{Mn}, \mathrm{Ni}, \mathrm{Pb}, \mathrm{Zn}$ & $\begin{array}{l}\text { Singh \& Narwall (1984); Bidwell \& Dowdy } \\
\text { (1987); King \& Hajjar (1990); Mulchi et al. } \\
\text { (1991); Roca \& Pomares (1991); Sims et al. } \\
\text { (1991); Oliveira (1995); Bertoncini (1997); } \\
\text { Miner et al (1997). }\end{array}$ \\
\hline EDTA-pH 4,65 & $\mathrm{Pb}$ & Roca \& Pomares (1991). \\
\hline EDTA-pH 8,6 & $\mathrm{Ni}, \mathrm{Pb}$ & Roca \& Pomares (1991). \\
\hline $\mathrm{HCl} 0,1 \mathrm{~mol} \mathrm{~L}^{-1}$ & $\mathrm{Cd}, \mathrm{Cr}, \mathrm{Cu}, \mathrm{Ni}, \mathrm{Zn}$ & Roca \& Pomares (1991); Bertoncini (1997). \\
\hline Mehlich 1 & $\mathrm{Cd}, \mathrm{Cu}_{,} \mathrm{Mn}, \mathrm{Ni}, \mathrm{Zn}$ & Mulchi et al. (1991); Sims et al. (1991). \\
\hline Mehlich 3 & $\mathrm{Cd}, \mathrm{Cu}, \mathrm{Ni}, \mathrm{Pb}, \mathrm{Zn}$ & $\begin{array}{l}\text { Roca \& Pomares (1991); Bertoncini (1997); } \\
\text { Miner et al. (1997). }\end{array}$ \\
\hline
\end{tabular}

\subsubsection{Legislação}

Nos Estados Unidos e países da Comunidade européia já existem critérios estabelecidos que orientam o uso agrícola de biossólidos.

Nos Estados Unidos e nos países seguidores das normas norte-americana, tais como Austrália, os limites para os poluentes no biossólido são fixados sob o conceito de administrar um risco ambiental aceitável. Procede-se à análise da exposição ao risco e da dose de resposta, caracterizando-se o risco pelas abordagens probabilística e de cálculo da concentração que causaria a primeira indicação de fitotoxicidade (Santos, 1998). 
McBride (1995) e Chang et al. (1997) criticaram a regulamentação da Agência de Proteção Ambiental dos Estados Unidos (USEPA-503) de 1993 que permitiu, pela aplicação de biossólidos, aumentar de dez a cem ou mais vezes a concentração local de metais potencialmente tóxicos em áreas agrícolas.

$\mathrm{Na}$ Comunidade Européia, as bases para o uso controlado de biossólidos na agricultura foram estabelecidas pela implementação da Diretriz da Comunidade Européia 86/278/EEC em 1989, após anos de negociação e de consideráveis pesquisas (Hall, 1998). Os limites para poluentes nos biossólidos baseiam-se nas concentrações de poluentes autóctones e nas que pré-existem no solo, antes da aplicação do biossólido (Santos, 1998). Também levam em consideração a proteção da planta, do animal e da saúde humana através da cadeia alimentar solo/planta/animal, bem como inclui a redução de patógenos e considerações e restrições a seis elementos potencialmente tóxicos: $\mathrm{Zn}, \mathrm{Cu}, \mathrm{Ni}, \mathrm{Cd}, \mathrm{Pb}$ e $\mathrm{Hg}$ (Hall, 1998).

Os países membros da Comunidade Européia têm liberdade de estabelecer suas próprias restrições, principalmente quanto aos valores limites para os elementos potencialmente tóxicos no biossólido, solo e doses de aplicação, e assim o fizeram, existindo países que adotaram níveis mais baixos (Hall, 1998).

Comparando-se os limites de aplicação de biossólidos nos Estados Unidos (USEPA Parte 503) e na Comunidade Européia (Diretriz da Comunidade Européia 86/278/EEC), Tabelas 2 e 3, verifica-se que os limites estabelecidos pela USEPA são geralmente maiores do que os limites recomendados pela Diretriz da Comunidade Européia, entretanto, alguns valores limites de qualidade são considerados menores que o máximo permitido. Isto reflete as prioridades políticas, econômicas e ambientais de cada país (Hall, 1998).

No Brasil, atualmente os estados do Paraná e São Paulo estão se valendo, respectivamente, das normas elaboradas pela Comunidade Européia e pelos E.U.A. para controlar a aplicação de biossólidos em áreas de uso agrícola, devido a falta de estudos locais para o estabelecimento de legislação própria. 
Tabela 2. Comparação dos limites de qualidade dos biossólidos estabelecidos pela USEPA 40 CFR Parte 503 e pela Diretriz da Comunidade Européia 86/278/EEC. Valores expressos em $\mathrm{mg} \mathrm{kg}^{-1}$ de matéria seca.

\begin{tabular}{|c|c|c|c|c|}
\hline \multirow{2}{*}{$\begin{array}{c}\text { Elementos } \\
\text { Potencialmente } \\
\text { tóxicos }\end{array}$} & \multicolumn{2}{|c|}{ USEPA Parte 503} & \multicolumn{2}{|c|}{ Diretriz da Comunidade Européia 86/278/EEC } \\
\hline & $\begin{array}{l}\text { Concentração } \\
\text { máxima }\end{array}$ & $\begin{array}{l}\text { Qualidade } \\
\text { excepcional }\end{array}$ & $\begin{array}{l}\text { Concentração } \\
\text { recomendada }\end{array}$ & Concentração máxima \\
\hline & \multicolumn{2}{|c|}{$\mathrm{mg} \mathrm{kg}^{-1}-\cdots$} & $\cdots$ & $g-\ldots$ \\
\hline $\mathrm{Zn}$ & 7.500 & 2.800 & 2.500 & 4.000 \\
\hline $\mathrm{Cu}$ & 4.300 & 1.500 & 1.000 & 1.750 \\
\hline $\mathrm{Ni}$ & 420 & 420 & 300 & 400 \\
\hline $\mathrm{Cd}$ & 85 & 39 & 20 & 40 \\
\hline $\mathrm{Pb}$ & 840 & 300 & 750 & 1.200 \\
\hline $\mathrm{Hg}$ & 57 & 17 & 16 & 25 \\
\hline $\mathrm{Cr}$ & 3.000 & 1.200 & - & - \\
\hline Mo & 75 & 18 & - & - \\
\hline $\mathrm{Se}$ & 100 & 36 & - & - \\
\hline As & 75 & 41 & - & - \\
\hline
\end{tabular}

Fonte: Hall (1998)

Segundo Raij (1998), o problema de uso de biossólidos no Brasil é, principalmente, de regulamentação. $\mathrm{O}$ assunto é suficientemente conhecido para que seja possível desenvolvê-la. Por outro lado, a pesquisa agronômica é necessária para ajustes no uso do produto e verificação dos problemas mais críticos, principalmente visando manter o uso de biossólidos e outros resíduos dentro de parâmetros técnicos seguros do ponto de vista ambiental.

Neste contexto, é imprescindível o desenvolvimento de trabalhos que permitam estabelecer a capacidade de acumulação de metais em solos de regiões tropicais, ao se aplicar os biossólidos, bem como, que avaliem o comportamento dos metais nestes solos em razão do cultivo com plantas e da não contaminação das águas subterrâneas. 
Tabela 3. Comparação dos limites de aplicação anual de biossólidos e de padrão de qualidade do solo estabelecidos pela USEPA 40 CRF Parte 503 e pela Diretriz da Comunidade Européia 86/278/EEC.

\begin{tabular}{|c|c|c|c|c|}
\hline \multirow{2}{*}{$\begin{array}{c}\text { Elementos } \\
\text { Potencialmente } \\
\text { tóxicos }\end{array}$} & \multicolumn{2}{|c|}{ Limites de aplicação } & \multicolumn{2}{|c|}{ Concentração no solo } \\
\hline & USEPA & $\begin{array}{l}\text { Comunidade } \\
\text { Européia }^{(1)}\end{array}$ & USEPA $^{(2)}$ & $\begin{array}{c}\text { Comunidade } \\
\text { Européia }\end{array}$ \\
\hline & \multicolumn{2}{|c|}{$\mathrm{kg} \mathrm{ha}^{-1} \mathrm{ano}^{-1}$} & \multicolumn{2}{|c|}{$-\mathrm{mg} \mathrm{kg}_{-}^{-1}$ de MS } \\
\hline $\mathrm{Zn}$ & 140 & 30 & 1.460 & $150-450^{(3)}$ \\
\hline $\mathrm{Cu}$ & 75 & 12 & 770 & $50-210^{(3)}$ \\
\hline $\mathrm{Ni}$ & 21 & 3 & 230 & $30-112^{(3)}$ \\
\hline $\mathrm{Cd}$ & 1,9 & 0,15 & $20^{(4)}$ & $1-3$ \\
\hline $\mathrm{Pb}$ & $15^{(4)}$ & 15 & $180^{(4)}$ & $50-300$ \\
\hline $\mathrm{Hg}$ & 0,85 & 0,1 & $8,5^{(4)}$ & $1-1,5$ \\
\hline $\mathrm{Cr}$ & 150 & - & 1.530 & - \\
\hline Mo & $0,9^{(5)}$ & - & $9,5^{(5)}$ & - \\
\hline $\mathrm{Se}$ & 5 & - & $50^{(4)}$ & - \\
\hline As & 2 & - & $21^{(4)}$ & - \\
\hline
\end{tabular}

Fonte: Hall (1998)

(1) A taxa de aplicação é a média acima de dez anos nos Estados Unidos.

(2) Valores calculados com base na Parte 503, não determina limites no solo para elementos potencialmente tóxicos.

(3) Valores maiores são permitidos para solos calcários contendo valores maiores que $5 \%$ de carbonato de cálcio.

(4) Para proteger as crianças, que comem $0,2 \mathrm{~g} \mathrm{dia}^{-1}$ de biossólidos aplicados em jardins, nos primeiros cinco anos de vida.

${ }^{(5)}$ Este elemento foi retirado para reavaliação. 


\section{MATERIAL E MÉTODOS}

\subsection{Solos}

Neste estudo foram utilizadas amostras de terras retiradas de um Latossolo Roxo distrófico textura argilosa (Rhodic Hapludox, clayey/LR) e Latossolo Vermelho Amarelo distrófico textura média (Typic Hapludox, coarse loamy/LV), ambas coletadas de áreas cultivadas com cana de açúcar na região de Piracicaba, SP. Estes solos foram escolhidos em função de sua classe textural e teor de óxidos. As amostras de terra foram coletadas nas camadas de $0-30 \mathrm{~cm}$ e $30-60 \mathrm{~cm}$ e submetidas a caracterizações químicas (Tabela 4), granulométrica e teores totais de óxidos de silício, ferro e alumínio (Tabela 5), de acordo com metodologias descritas por Camargo et al. (1986) e Raij et al. (1987).

Tabela 4. Características químicas das terras utilizadas na instalação do experimento ${ }^{(1)}$.

\begin{tabular}{|c|c|c|c|c|c|c|c|c|c|c|c|c|}
\hline Amostras & $\begin{array}{c}\mathrm{pH} \\
\mathrm{CaCl}_{2}\end{array}$ & 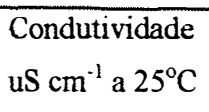 & $\begin{array}{l}\text { M.O. } \\
\mathrm{g} \mathrm{kg}^{-1}\end{array}$ & $\begin{array}{l}\text { P resina } \\
\mathrm{mg} \mathrm{kg}^{-1}\end{array}$ & $\underline{\mathrm{K}^{+}}$ & $\mathrm{Ca}^{2+}$ & $\begin{array}{c}\mathrm{Mg}^{27} \\
--m\end{array}$ & $\begin{array}{l}\mathrm{H}+\mathrm{Al} \\
\mathrm{ol}_{\mathrm{c}} \mathrm{kg}\end{array}$ & $\mathrm{Al}^{3+-}$ & $\overline{\mathrm{SB}}$ & CTC & V\% \\
\hline LV $0-30 \mathrm{~cm}$ & $\begin{array}{c}0,01 \mathrm{~mol} \mathrm{~L}^{-1} \\
4,3\end{array}$ & 118 & 15 & 6 & 0,2 & 8 & 2,3 & 24 & 2,3 & 10 & 34 & 29 \\
\hline LV $30-60 \mathrm{~cm}$ & 4,2 & 152 & 9 & 5 & 0,1 & 6 & 2,3 & 24 & 3,1 & 9 & 33 & 26 \\
\hline LR 0-30 cm & 4,4 & 182 & 32 & 13 & 1,2 & 22 & 4,6 & 48 & 2,8 & 28 & 76 & 36 \\
\hline LR $30-60 \mathrm{~cm}$ & 4,8 & 170 & 19 & 4 & 0,1 & 19 & 2,8 & 35 & 0,9 & 22 & 57 & 38 \\
\hline
\end{tabular}


Tabela 5. Granulometria e teores totais de óxidos de silício, ferro e alumínio das terras utilizadas na instalação do experimento ${ }^{(1)}$.

\begin{tabular}{|c|c|c|c|c|c|c|c|}
\hline Amostras & argila & areia grossa & areia fina & silte & $\mathrm{SiO}_{2}$ & $\mathrm{Fe}_{2} \mathrm{O}_{3}$ & $\mathrm{Al}_{2} \mathrm{O}_{3}$ \\
\hline LR $0-30 \mathrm{~cm}$ & 593 & 9 & 208 & 109 & 184 & 126 & 192 \\
\hline LR $30-60 \mathrm{~cm}$ & 616 & 67 & 209 & 108 & 193 & 128 & 206 \\
\hline LV 0-30 cm & 151 & 326 & 492 & 31 & 59 & 16 & 45 \\
\hline LV 30-60 cm & 161 & 304 & 528 & 7 & 68 & 17 & 50 \\
\hline
\end{tabular}

${ }^{7 \pi}$ Análises segundo Camargo et al. (1986).

\subsection{Biossólido}

O biossólido utilizado no experimento foi proveniente da Estação de Tratamento de Esgotos da SABESP, localizada em Barueri - SP, que emprega como processo de tratamento do esgoto a digestão anaeróbia do lodo ativado, seguido da adição de cal e $\mathrm{FeCl}_{3}$ para, respectivamente, impedir a atividade biológica e facilitar a eliminação de água do mesmo, que é feita através de prensagem. Todo o biossólido utilizado no experimento foi proveniente de uma única partida, que foi armazenada à céu aberto. Por este motivo, antes de cada nova aplicação este resíduo foi amostrado e analisado. Algumas características químicas de uma amostra composta do referido material, feita em triplicata, aparecem na Tabela 6. Esta caracterização química foi realizada segundo a metodologia de Tedesco et al. (1995) e Eaton et al. (1995). 
Tabela 6. Caracterização química do biossólido utilizado nas cinco aplicações. Valores médios de três repetições ${ }^{(1)}$

\begin{tabular}{|c|c|c|c|c|c|c|c|c|c|c|}
\hline \multirow{2}{*}{$\begin{array}{l}\text { Lodos } \\
1^{\mathrm{a}} \text { aplicação }\end{array}$} & \multirow{2}{*}{$\begin{array}{c}\mathrm{U} 65^{\circ} \mathrm{C} \\
520\end{array}$} & M.O. & \multirow{2}{*}{$\begin{array}{c}\text { C-oxid. } \\
113\end{array}$} & $\mathrm{~N}$ & $\mathrm{P}$ & \multicolumn{2}{|c|}{$\bar{K}$} & $\mathrm{Ca}$ & $\mathrm{Mg}$ & \multirow{2}{*}{$\begin{array}{c}\mathrm{pH} \\
\mathrm{CaCl}_{2}\end{array}$} \\
\hline & & 221 & & 9,41 & 7,91 & \multicolumn{2}{|c|}{1,66} & 136 & 3,71 & \\
\hline $2^{\mathrm{a}}$ aplicação & 498 & 199 & 98 & 9,76 & 8,22 & \multicolumn{2}{|c|}{1,50} & 130 & 3,28 & 7,5 \\
\hline $3^{\mathrm{a}}$ aplicação & 484 & 197 & 124 & 13,08 & 8,81 & \multicolumn{2}{|c|}{1,72} & 130 & 2,90 & 6,9 \\
\hline $4^{\mathrm{a}}$ aplicação & 446 & 190 & 107 & 9,56 & 8,94 & \multicolumn{2}{|c|}{1,46} & 138 & 2,80 & 7,6 \\
\hline $5^{\text {a }}$ aplicação & 467 & 188 & 107 & 9,69 & 9,58 & \multicolumn{2}{|c|}{1,55} & 144 & 3,79 & 7,6 \\
\hline \multirow{2}{*}{ Lodos } & $\overline{\mathrm{PN}}$ & $\overline{\mathrm{Na}}$ & $\overline{\mathrm{S}}$ & $\overline{\mathrm{Cd}}$ & $\mathrm{Cr}$ & $\overline{\mathrm{Cu}}$ & $\mathrm{Ni}$ & Mn & $\mathrm{Pb}$ & $\overline{\mathrm{Zn}}$ \\
\hline & $\begin{array}{c}\% \mathrm{CaCO}_{3} \\
\text { equiv }\end{array}$ & \multicolumn{2}{|c|}{ 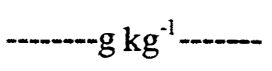 } & & & & & & & \\
\hline $1^{a}$ aplicação & 25,46 & 0,48 & 5,13 & 17 & 383 & 741 & 390 & 331 & 193 & 1.835 \\
\hline $2^{\mathrm{a}}$ aplicação & 33,45 & 0,28 & 8,13 & 21 & 447 & 683 & 365 & 340 & 137 & 1.836 \\
\hline $3^{\mathrm{a}}$ aplicação & 27,91 & 0,39 & 6,96 & 17 & 495 & 729 & 373 & 299 & 185 & 1.927 \\
\hline $4^{\mathrm{a}}$ aplicação & 33,40 & 0,39 & 7,47 & 23 & 559 & 803 & 310 & 358 & 135 & 2.020 \\
\hline $5^{\mathrm{a}}$ aplicação & 33,44 & 0,39 & 8,26 & 25 & 596 & 847 & 379 & 380 & 129 & 2.212 \\
\hline
\end{tabular}

(1) Os resultados de $\mathrm{pH}$ foram expressos no material original, os demais resultados no material seco a $65^{\circ} \mathrm{C}$. Os teores dos elementos referem-se aos teores totais encontrados no biossólido.

\subsection{Instalação do experimento}

O experimento foi instalado a céu aberto, em 19 de outubro de 1996, em área do Departamento de Ciências Exatas/Química Ambiental da Escola Superior de Agricultura "Luiz de Queiroz", ESALQ-USP, Piracicaba, SP, segundo delineamento em blocos ao acaso com 4 tratamentos:

Tratamento 1: Latossolo Vermelho Amarelo + lodo (LV+lodo);

Tratamento 2: Latossolo Vermelho Amarelo, testemunha (LV);

Tratamento 3: Latossolo Roxo + lodo (LR+lodo);

Tratamento 4: Latossolo Roxo, testemunha (LR).

Os tratamentos tiveram quatro repetições, totalizando 16 parcelas distribuídas aleatoriamente em quatro blocos distintos. Cada parcela foi composta por uma caixa de amianto, com capacidade para $0,500 \mathrm{~m}^{3}$, preenchida a partir do fundo com: uma tela fina 
de plástico, $4 \mathrm{~cm}$ de pedra brita lavada $\mathrm{n}^{\mathbf{o}} 1$, novamente tela fina de plástico, $2 \mathrm{~cm}$ de areia, $27 \mathrm{~cm}$ de terra retirada da profundidade de $30-60 \mathrm{~cm}$ e $27 \mathrm{~cm}$ da profundidade de 0-30 cm. Cada caixa comportou $555,86 \mathrm{~kg}$ de LV ou 486,14 $\mathrm{kg}$ de LR.

Antes da adição do biossólido às parcelas experimentais, foi realizada a determinação da densidade do solo nas caixas, pelo método do anel volumétrico (Camargo et al., 1986), sendo que o Latossolo Roxo apresentou uma densidade média de $1,09 \mathrm{~g} \mathrm{~cm}^{-3}$, enquanto que o Latossolo Vermelho Amarelo, uma densidade média de 1,29 $\mathrm{g} \mathrm{cm}^{-3}$.

\subsection{Condução do experimento}

\subsubsection{Aplicações de biossólido}

A Tabela 7 apresenta as quantidades de biossólido aplicadas aos tratamentos em cada período, em base seca. As quantidades diferiram de uma aplicação para outra devido a variação de umidade do biossólido utilizado.

Tabela 7. Quantidade de biossólido adicionado às amostras de terra contidas nas caixas.

\begin{tabular}{|c|c|c|c|}
\hline \multirow[t]{2}{*}{ Aplicaçōes } & \multirow[t]{2}{*}{ Data } & \multicolumn{2}{|c|}{ Quantidade aplicada em base seca } \\
\hline & & $\mathrm{Mg} \mathrm{ha}^{-1}$ & -...-kg caixa ${ }^{-1(1)}$ \\
\hline $1^{\text {a }}$ aplicação & $23 / 11 / 96$ & 72,09 & 6,36 \\
\hline $2^{a}$ aplicação & $08 / 02 / 97$ & 75,37 & 6,65 \\
\hline $3^{a}$ aplicação & $11 / 04 / 97$ & 77,41 & 6,83 \\
\hline $4^{\mathrm{a}}$ aplicação & $13 / 06 / 97$ & 83,03 & 7,33 \\
\hline $5^{\mathbf{a}}$ aplicação & $16 / 08 / 97$ & 79,99 & 7,06 \\
\hline Total & & 387,89 & 34,23 \\
\hline
\end{tabular}

[) Area da caixa $=0,8825 \mathrm{~m}^{2} ; \mathrm{d}(\mathrm{LR})=1,09 \mathrm{~g} \mathrm{~cm}^{-3}: \mathrm{d}(\mathrm{LV})=1,29 \mathrm{~g} \mathrm{~cm}^{-3}$

O biossólido foi adicionado à superficie das caixas e dois dias após a sua 
aplicação foi feita a incorporação a $20 \mathrm{~cm}$ de profundidade.

O aspecto geral da primeira aplicação de biossólido antes de sua incorporação pode ser vista na Figura 1.

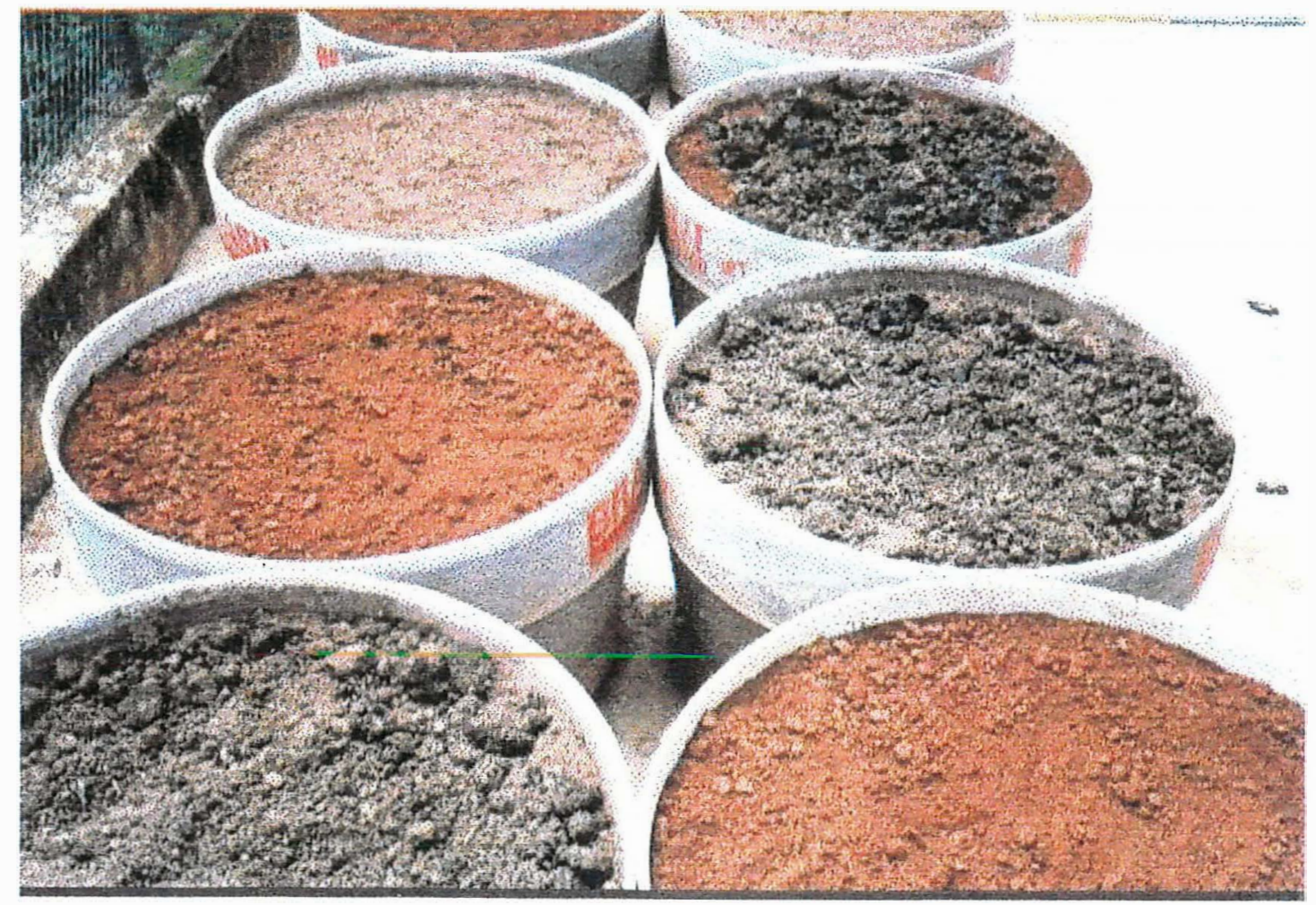

Figura 1 - Aspecto geral do experimento por ocasião da primeira aplicação de biossólido, antes da incorporação deste material a $20 \mathrm{~cm}$.

Na Tabela 8 encontra-se as quantidades de $\mathrm{N}, \mathrm{P}, \mathrm{K}, \mathrm{Ca}$ e $\mathrm{Mg}$ adicionadas às amostras de terra em cada aplicação. 
Tabela 8. Quantidades de $\mathrm{N}, \mathrm{P}, \mathrm{K}, \mathrm{Ca}$ e $\mathrm{Mg}$ incorporadas às amostras de terra pelas aplicações de biossólido.

\begin{tabular}{|c|c|c|c|c|c|c|}
\hline \multirow{2}{*}{$\begin{array}{l}\text { Aplicações } \\
1^{\mathrm{a}} \text { aplicação }\end{array}$} & \multicolumn{2}{|c|}{ - } & \multicolumn{2}{|c|}{ 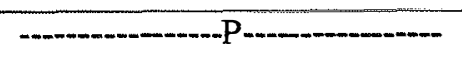 } & \multicolumn{2}{|c|}{ K- } \\
\hline & $\begin{array}{c}\mathrm{kg} \mathrm{ha}^{-1} \\
678\end{array}$ & $\begin{array}{l}\text { g caixa }^{-1(1)} \\
60\end{array}$ & $\begin{array}{c}\mathrm{kg} \mathrm{ha}^{-1} \\
571\end{array}$ & $\begin{array}{c}\text { g caixa } \\
50\end{array}$ & $\begin{array}{l}\mathrm{kg} \mathrm{ha}^{-1} \\
119\end{array}$ & $\begin{array}{c}\text { g caixa }^{-1} \\
10\end{array}$ \\
\hline $2^{\mathrm{a}}$ aplicação & 736 & 65 & 621 & 55 & 113 & 10 \\
\hline $3^{\mathrm{a}}$ aplicação & 1.012 & 89 & 682 & 60 & 99 & 12 \\
\hline $4^{\mathrm{a}}$ aplicação & 794 & 70 & 743 & 66 & 121 & 11 \\
\hline $5^{\mathrm{a}}$ aplicação & 775 & 68 & 767 & 68 & 124 & 11 \\
\hline \multirow[t]{2}{*}{ Total } & 3.996 & 353 & 3.384 & 299 & 577 & 54 \\
\hline & (n) & $-\mathrm{Ca}-\cdots$ & (n) & - & $--\mathrm{Mg}-$ & 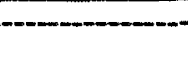 \\
\hline $1^{\mathrm{a}}$ aplicação & $\begin{array}{l}\mathrm{kg} \mathrm{ha}^{-1} \\
9.769\end{array}$ & & $\begin{array}{c}\text { g caixa }^{-1} \\
826\end{array}$ & $\begin{array}{l}\mathrm{kg} \mathrm{ha}^{-1} \\
268\end{array}$ & & $\begin{array}{c}\text { g caixa }^{-1} \\
24\end{array}$ \\
\hline $2^{\mathrm{a}}$ aplicação & 9.817 & & 866 & 247 & & 22 \\
\hline $3^{\mathrm{a}}$ aplicação & 10.038 & & 886 & 224 & & 20 \\
\hline $4^{\mathfrak{a}}$ aplicação & 11.470 & & 1.012 & 232 & & 20 \\
\hline $5^{\mathrm{a}}$ aplicação & 11.556 & & 1.020 & 202 & & 27 \\
\hline Total & 52.651 & & 4.646 & 1.173 & & 112 \\
\hline
\end{tabular}

As quantidades de metais adicionadas às amostras de terra em cada aplicação de biossólido são apresentadas na Tabela 9. 
Tabela 9. Quantidades de metais incorporadas às amostras de terra na profundidade de $20 \mathrm{~cm}$ pelas aplicações de biossólido.

\begin{tabular}{|c|c|c|c|c|c|c|c|c|c|}
\hline Aplicações & \multicolumn{5}{|c|}{-Cd- } & 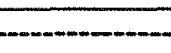 & - & - & - \\
\hline & \multicolumn{2}{|c|}{$\mathrm{LV}^{(n)}$} & $\mathrm{LR}^{(2)}$ & \multirow{2}{*}{\multicolumn{2}{|c|}{ g caixa $^{-1(3)}$}} & LV & \multicolumn{2}{|l|}{$\overline{\mathrm{LR}}$} & \\
\hline & \multicolumn{2}{|c|}{$\mathrm{mg} \mathrm{kg}^{-1}$} & $\mathrm{mg} \mathrm{kg}^{-1}$ & & & $\mathrm{mg} \mathrm{kg}^{-1}$ & $\mathrm{mg} \mathrm{kg} \mathrm{g}^{-1}$ & & g caixa $^{-1}$ \\
\hline $\mathrm{l}^{\underline{a}}$ aplicação & \multicolumn{2}{|c|}{0,48} & 0,57 & \multicolumn{2}{|c|}{0,11} & 20,72 & 24,52 & & 4,22 \\
\hline $2^{\mathrm{a}}$ aplicação & \multicolumn{2}{|c|}{0,60} & 0,71 & \multicolumn{2}{|c|}{0,14} & 19,97 & 23,63 & & 4,54 \\
\hline $3^{\mathfrak{a}}$ aplicação & \multicolumn{2}{|c|}{0,50} & 0,59 & \multicolumn{2}{|c|}{0,11} & 21,88 & 25,90 & & 4,98 \\
\hline $4^{\mathrm{a}}$ aplicação & \multicolumn{2}{|c|}{0,75} & 0,89 & \multicolumn{2}{|c|}{0,17} & 25,83 & \multicolumn{2}{|l|}{30,57} & 5,88 \\
\hline $5^{\underline{a}}$ aplicação & \multicolumn{2}{|c|}{0,79} & 0,93 & \multicolumn{2}{|c|}{0,18} & 26,25 & \multicolumn{2}{|l|}{31,07} & 5,98 \\
\hline Total & \multicolumn{2}{|c|}{3,12} & 3,70 & \multicolumn{2}{|c|}{0,71} & 114,64 & \multicolumn{2}{|l|}{135,68} & 25,60 \\
\hline \multicolumn{10}{|l|}{ Aplicações } \\
\hline & \multicolumn{3}{|c|}{$\begin{array}{ll}\text { LV } & \text { LR }\end{array}$} & $\overline{L V}$ & \multicolumn{2}{|l|}{ LR } & $\mathrm{LV}$ & \multicolumn{2}{|l|}{ LR } \\
\hline & \multirow{2}{*}{$\begin{array}{c}\mathrm{mg} \mathrm{kg}^{-1} \\
10,70\end{array}$} & $\mathrm{mg} \mathrm{kg}^{-1}$ & g caixa ${ }^{-1}$ & $\mathrm{mg} \mathrm{kg}^{-1}$ & $\mathrm{mg} \mathrm{kg}^{-1}$ & g caixa $^{-1}$ & $\mathrm{mg} \mathrm{kg}{ }^{-1}$ & \multirow{2}{*}{$\begin{array}{r}\mathrm{mg} \mathrm{kg}^{-1} \\
12,90\end{array}$} & $\mathrm{~g} \mathrm{caixa}^{-1}$ \\
\hline $1^{\text {a }}$ aplicação & & 12,67 & 2,44 & 9,25 & 10,95 & 2,10 & 10,90 & & 2,48 \\
\hline $2^{\underline{a}}$ aplicação & 13,06 & 15,45 & 2,97 & 9,93 & 11,76 & 2,26 & 10,66 & 12,61 & 2,43 \\
\hline $3^{3}$ aplicação & 14,84 & 17,57 & 3,38 & 8,97 & 10,62 & 2,04 & 11,20 & 13,26 & 2,55 \\
\hline $4^{\mathrm{a}}$ aplicação & 17,98 & 21,28 & 4,09 & 11,52 & 13,64 & 2,62 & 9,98 & 11,81 & 2,27 \\
\hline $5^{\mathbf{a}}$ aplicação & 18,48 & 21,87 & 4,21 & 11,78 & 13,94 & 2,68 & 11,76 & 13,92 & 2,68 \\
\hline Total & 75,06 & 88,83 & 17,09 & 51,46 & 60,90 & 11,72 & 54,50 & 64,50 & 12,41 \\
\hline Aplicações & 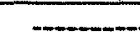 & & --Pb- & $\ldots$ & $\ldots$ & 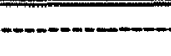 & $--\mathrm{Zn}-$ & & $\ldots$ \\
\hline & $\overline{L V}$ & & LR & & & $\mathrm{LV}$ & $\mathrm{LR}$ & & \\
\hline $1^{\mathrm{a}}$ aplicação & $\begin{array}{r}\mathrm{mg} \mathrm{k} \\
5.3\end{array}$ & & $\begin{array}{c}\mathrm{mg} \mathrm{kg}^{-1} \\
6.37\end{array}$ & $\begin{array}{r}\text { g cai. } \\
1.2\end{array}$ & & $\begin{array}{c}\mathrm{mg} \mathrm{kg}^{-1} \\
51,26\end{array}$ & $\begin{array}{r}\mathrm{mg} \mathrm{kg}^{-} \\
60.67\end{array}$ & & ${\underset{11,67}{\text { g caixa }}}^{-1}$ \\
\hline $2^{\underline{a}}$ aplicação & 3,9 & & 4,72 & 0,9 & & 53,65 & 63,50 & & 12,22 \\
\hline $3^{\mathbf{a}}$ aplicação & 5,5 & & 6,56 & 1.2 & & 57,81 & 68,42 & & 13,16 \\
\hline $4^{\mathrm{a}}$ aplicação & 4,3 & & 5,11 & 0,9 & & 65,02 & 76,95 & & 14,80 \\
\hline 5ª aplicação & 3,9 & & 4,72 & 0,9 & & 65,58 & 81,16 & & 15,61 \\
\hline Total & 23,2 & & 27,49 & 5.2 & & 296,32 & 350,69 & & 67,47 \\
\hline
\end{tabular}

(T) $\mathrm{d}(\mathrm{LV})=1,29 \mathrm{~g} \mathrm{~cm}^{-3} ; \mathrm{V}=0,1765 \mathrm{~m}^{-3}$ de terra até a profundidade de $20 \mathrm{~cm}$;

(2) $\mathrm{d}(\mathrm{LR})=1,09 \mathrm{~g} \mathrm{~cm}^{-3}$;

${ }^{(3)}$ Área da caixa $=0.8825 \mathrm{~m}^{2}$. 


\subsubsection{Amostragens e análises de terra}

Decorridos aproximadamente dois meses de cada aplicação de biossólido, as terras contidas nas caixas foram amostradas na profundidade de $0-20 \mathrm{~cm}$. Coletou-se seis amostras simples que reunidas constituíram uma amostra composta correspondente aquela parcela experimental. As amostras obtidas foram secas ao ar, destorroadas e passadas em peneira de abertura de malha de $2 \mathrm{~mm}$, sendo submetidas logo em seguida a análise de condutividade elétrica em suspensão solo/água na proporção $1: 1$, de acordo com metodologia estabelecida por Camargo et al. (1986) e as análises de $\mathrm{pH}$ em $\mathrm{CaCl}_{2}$ $0,01 \mathrm{~mol} \mathrm{~L}^{-1}$ na proporção 1:2,5, K, Ca e Mg de acordo com Raij et al (1987). Ao todo foram feitas cinco amostragens de terra. Essas análises foram realizadas com a finalidade de ajudar a entender o comportamento dessas mesmas variáveis na solução percolada durante o ano de aplicação do biossólido.

Por ocasião do cultivo de milho foi realizada nova determinação densidade do solo, pelo método de anel volumétrico (Camargo et al., 1986) e amostragens de terra das caixas à mesma profundidade. As amostras de terra, após preparadas conforme comentado anteriormente, foram submetidas as análises de rotina (Camargo et al., 1986; Raij et al., 1987), de micronutrientes (Lindsay \& Norvell, 1978; Tedesco et al., 1995) e de $\mathrm{N}$ total (Alcarde \& Chitolina, 1991), a fim de se avaliar a necessidade de calagem e adubação da cultura (Tabelas 10 e 11, respectivamente) desenvolvida nos tratamentos que não receberam o biossólido. A avaliação da eficiência dos extratores foi feita nestas amostras de terra. O detalhamento sobre esta avaliação é feita no capítulo: Avaliação de extratores. 
Tabela 10. Parâmetros de avaliação da fertilidade da terra e condutividade elétrica dos tratamentos 47 dias após a última aplicação de biossólido ${ }^{(1)}$. Valores médios de quatro repetições.

\begin{tabular}{|c|c|c|c|c|c|c|c|}
\hline \multirow[b]{2}{*}{ Tratamentos } & Conduti- & \multicolumn{3}{|c|}{$\mathrm{pH}$} & \multirow{2}{*}{$\begin{array}{c}\mathrm{C} \\
\mathrm{g} \mathrm{kg}^{-1}\end{array}$} & \multirow{2}{*}{$\begin{array}{c}\mathrm{P} \text { (resina) } \\
\mathrm{mg} \mathrm{kg}^{-1}\end{array}$} & \multirow{2}{*}{$\begin{array}{c}\mathrm{K}^{+} \\
\mathrm{mmol}_{\mathrm{c}} \mathrm{kg}^{-1}\end{array}$} \\
\hline & $\begin{array}{l}\mu S \mathrm{~cm}^{-1} \\
\text { a } 25^{\circ} \mathrm{C}\end{array}$ & Agua & \multicolumn{2}{|c|}{$\mathrm{CaCl}_{2} 0,01 \mathrm{~mol} \mathrm{~L}^{-1}$} & & & \\
\hline LV+lodo & 834 & 7,4 & \multicolumn{2}{|c|}{7,4} & 8,6 & 96,0 & 1,3 \\
\hline LV & 50 & 5,4 & \multicolumn{2}{|c|}{4,8} & 4,4 & 7,4 & 0,7 \\
\hline LR+lodo & 1.052 & 7,3 & \multicolumn{2}{|c|}{7,3} & 18,1 & 134,1 & 2,1 \\
\hline LR & 102 & 5,1 & \multicolumn{2}{|c|}{4,9} & 10,5 & 12,6 & 1,3 \\
\hline \multirow[b]{2}{*}{ Tratamentos } & $\mathrm{Ca}^{2+}$ & $\mathrm{Mg}^{2+}$ & $\mathrm{Al}^{3+}$ & $\overline{\mathrm{H}+\mathrm{Al}}$ & $\overline{S B}$ & CTC & V \\
\hline & 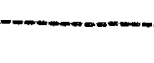 & $\cdots$ & \multicolumn{2}{|c|}{$-m_{c} \mathrm{~kg}^{-1}-$} & & & $\%$ \\
\hline LV+lodo & 52,0 & 2,9 & 1,3 & 5,8 & 56,2 & 62,0 & 90,58 \\
\hline LV & 8,8 & 3,3 & 3,2 & 26,8 & 12,8 & 39,5 & 32,24 \\
\hline LR+lodo & 121,3 & 6,1 & 1,5 & 6,3 & 132,0 & 138,3 & 95,43 \\
\hline LR & 20,7 & 4,9 & 5,4 & 47,3 & 26,8 & 74,0 & 36,08 \\
\hline
\end{tabular}

Tabela 11. Análise de micronutrientes nas terras antes do cultivo de milho. Valores médios de quatro repetições.

$\begin{array}{cccccc}\text { Tratamentos } & \mathrm{Cu}^{(\sqrt{n})} & \mathrm{Fe}^{(1)} & \mathrm{Zn}^{(1)} & \mathrm{Mn}^{(1)} & \mathrm{B}^{(2)}- \\ \text { LV+lodo } & 13,7 & 38,2 & 12,3 & 1,4 & 0,6 \\ \text { LV } & 0,2 & 35,3 & 1,1 & 1,2 & 0,5 \\ \text { LR+lodo } & 22,0 & 49,4 & 18,2 & 7,2 & 0,8 \\ \text { LR } & 1,9 & 20,4 & 1,0 & 23,8 & 0,8 \\ \text { Extrator DTPA pH 7,3, análise segundo Lindsay \& Norvell (1978); } & & \\ \text { Extrator água quente, análise segundo Tedesco et al. (1995). } & & \end{array}$




\subsubsection{Lixiviados coletados e análises realizadas}

Durante o ano de aplicação de biossólido foi realizada a coleta da água que lixiviava das parcelas experimentais. Como esta água era oriunda da precipitação atmosférica, a partir da primeira adição de biossólido, começou-se a fazer leituras diárias do pluviômetro às 9:00 horas e o monitoramento da água da chuva que percolava através das caixas.

As épocas de coleta de lixiviado correspondentes às aplicações do biossólido são apresentadas na Tabela 12. Ao todo, durante o periodo de 11 meses de monitoramento, ocorreram 19 coletas de lixiviado.

Tabela 12. Período de coleta dos lixiviados durante a aplicação de biossólido.

\begin{tabular}{|c|c|c|c|}
\hline Aplicaçð̄es & Coletas de lixiviado & Épocas & $\begin{array}{c}\text { Dias após a aplicação do } \\
\text { biossólido }\end{array}$ \\
\hline & $1^{\mathrm{a}}$ coleta & $8 / 12 / 96$ & 15 \\
\hline \multirow[t]{3}{*}{$1^{\mathrm{a}}$ aplicação } & $2^{\mathrm{a}}$ coleta & $10 / 12 / 96$ & 17 \\
\hline & $3^{\mathrm{a}}$ coleta & $18 / 12 / 96$ & 25 \\
\hline & $4^{\mathrm{a}}$ coleta & $17 / 02 / 97$ & 9 \\
\hline \multirow[t]{4}{*}{$2^{\mathrm{a}}$ aplicação } & $5^{\mathrm{a}}$ coleta & $19 / 02 / 97$ & 11 \\
\hline & $6^{\mathrm{a}}$ coleta & $14 / 03 / 97$ & 33 \\
\hline & $7^{\mathrm{a}}$ coleta & $11 / 04 / 97$ & 62 \\
\hline & $8^{\mathrm{a}}$ coleta & $13 / 05 / 97$ & 32 \\
\hline \multirow[t]{4}{*}{$3^{\mathrm{a}}$ aplicação } & $9^{\mathrm{a}}$ coleta & $30 / 05 / 97$ & 49 \\
\hline & $10^{\mathrm{a}}$ coleta & $05 / 06 / 97$ & 55 \\
\hline & $11^{\mathrm{a}}$ coleta & $13 / 06 / 97$ & 63 \\
\hline & $12^{\mathrm{a}}$ coleta & $15 / 06 / 97$ & 2 \\
\hline \multirow[t]{4}{*}{$4^{a}$ aplicação } & $13^{\mathrm{a}}$ coleta & $23 / 06 / 97$ & 10 \\
\hline & $14^{\mathrm{a}}$ coleta & $05 / 08 / 97$ & 53 \\
\hline & $15^{\mathrm{a}}$ coleta & $15 / 09 / 97$ & 30 \\
\hline & $16^{\mathrm{a}}$ coleta & $20 / 09 / 97$ & 35 \\
\hline \multirow[t]{3}{*}{$5^{a}$ aplicação } & $17^{\mathrm{a}}$ coleta & $22 / 09 / 97$ & 37 \\
\hline & $18^{\mathrm{a}}$ coleta & $30 / 09 / 97$ & 45 \\
\hline & $19^{\mathrm{a}}$ coleta & $02 / 10 / 97$ & 47 \\
\hline
\end{tabular}


A água lixiviada através das caixas foi recebida em galões de $20 \mathrm{~L}$ e quantificada. As caixas dispunham de uma válvula de fechamento que permitia coletar toda água lixiviada sem que os galões transbordassem (Figura 2). Após a quantificação da água lixiviada, retirava-se uma alíquota de aproximadamente $500 \mathrm{~mL}$ para a realização das análises.

As análises de condutividade elétrica, $\mathrm{pH}$ e a quantificação de $\mathrm{K}, \mathrm{Ca}, \mathrm{Mg}$ e metais pesados foram realizadas diretamente nos lixiviados coletados, seguindo a metodologia descrita por Eaton et al. (1995). Os teores de $\mathrm{Ca}, \mathrm{Mg}, \mathrm{Cd}, \mathrm{Cu}, \mathrm{Cr}, \mathrm{Ni}, \mathrm{Pb}$, $\mathrm{Zn}$ e Mn foram determinados por espectrofotometria de absorção atômica convencional, com chama, enquanto que os de $\mathrm{K}$ por fotometria de emissão de chama.

A análise das formas nitrogenadas $\mathrm{N}_{-}-\mathrm{NH}_{4}{ }^{+}+\mathrm{N}^{-} \mathrm{NO}_{3}{ }^{-}$foi realizada conforme metodologia estabelecida por Tedesco (1995) apenas nas três primeiras coletas de lixiviado, que estavam sob o efeito da primeira aplicação de biossólido e nas cinco últimas coletas, que estavam sob o efeito da última aplicação deste resíduo, pois o objetivo foi verificar variações nas quantidades de $\mathrm{N}$ lixiviadas após as aplicações de biossólido nas amostras de terra.

Também foi realizada a análise de $\mathrm{N}-\mathrm{NH}_{4}{ }^{+}$de acordo com Tedesco (1995). Esta análise indicou que praticamente a totalidade do $\mathrm{N}$ presente nos lixiviados (mais de $97 \%)$ estava na forma de nitrato $\left(\mathrm{N}^{-\mathrm{NO}_{3}}{ }^{-}\right)$. 


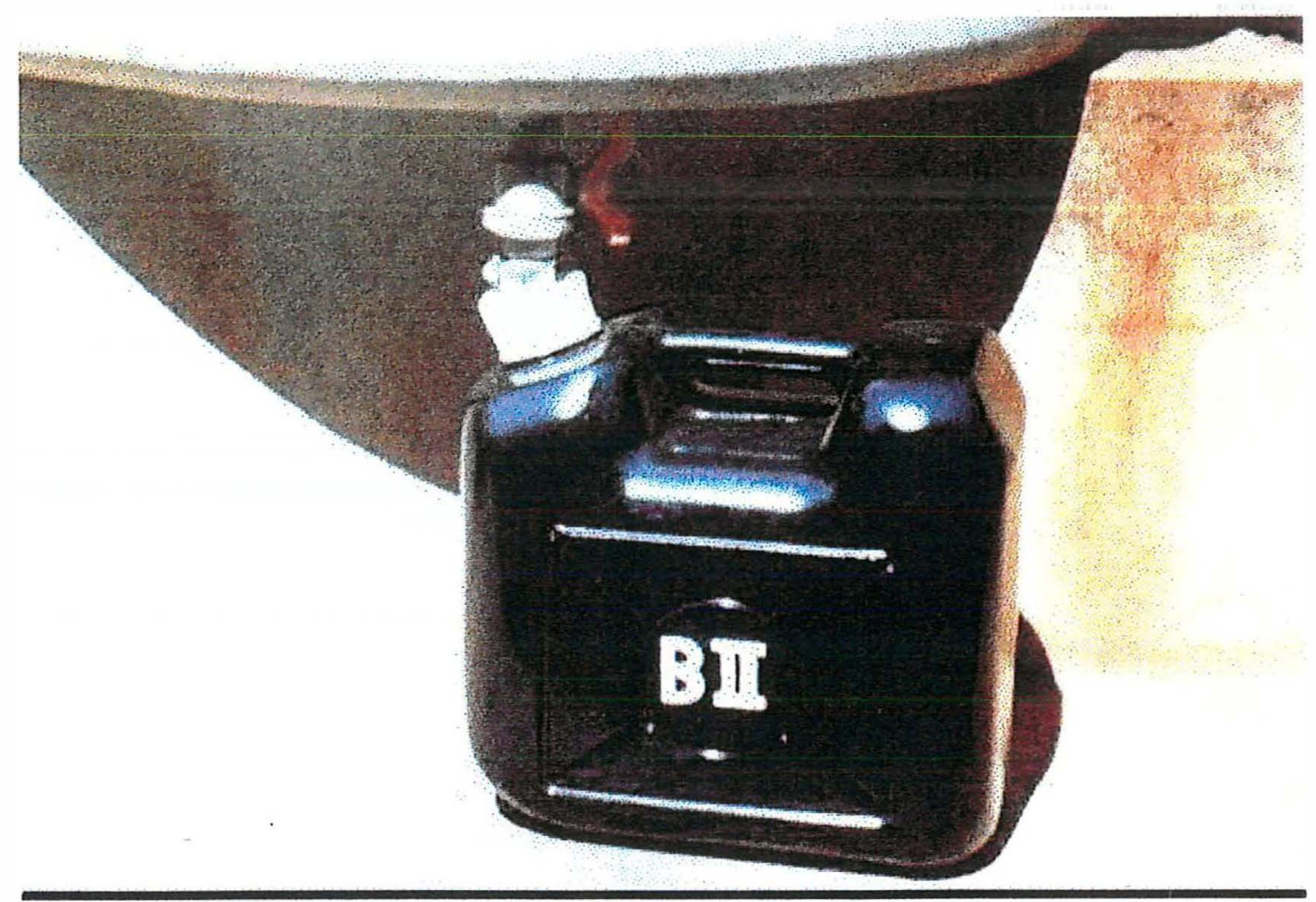

Figura 2 - Aspecto do galão de água que recebia o lixiviado.

\subsubsection{Fitodisponibilidade de metais no solo e avaliação de métodos de extração}

\subsubsection{Condução da cultura}

A fitodisponibilidade dos metais presentes nos solos foi avaliada através da planta de milho híbrido duplo Cargill C-444 (Zea mays L.). O milho foi semeado em 23 de outubro de 1997, dois meses após a última aplicação de biossólido.

A calagem nos tratamentos testemunha foi realizada com calcário calcinado, 19 dias antes do cultivo, e com base na análise de rotina (Tabela 10) e na elevação da saturação por bases à 70\% (Raij \& Cantarella, 1996). Para o cálculo considerou-se o volume de terra na caixa de $0,1765 \mathrm{~m}^{3}$ e a profundidade de incorporação do calcário de $20 \mathrm{~cm}$. Deste modo, o tratamento LV recebeu 122,43 g de calcário calcinado, enquanto que o tratamento LR, 205,25 g. As características físico-químicas do calcário calcinado 
foram realizadas conforme metodologia estabelecida por Koche et al. (1989), sendo apresentadas na Tabela 13.

Tabela 13. Características físico-químicas do calcário calcinado aplicado no experimento.

\begin{tabular}{cc}
\hline Características & Calcário calcinado \\
\hline Granulometria \% passando a Peneira 10 (ABNT) & 100,00 \\
Granulometria \% passando a Peneira 20 (ABNT) & 100,00 \\
Granulometria \% passando a Peneira 50(ABNT) & 87,76 \\
Umidade \% & 0,21 \\
$\mathrm{PN}\left(\mathrm{ECaCO}_{3}\right) \%$ & 112,93 \\
$\mathrm{CaO} \%$ & 32,30 \\
$\mathrm{MgO} \%$ & 22,34 \\
$\mathrm{CaO}+\mathrm{MgO}_{0}$ & 54,63 \\
$\mathrm{ECaCO}$ calculado \% & 113,21 \\
$\mathrm{PRNT} \%$ & 107,40 \\
\hline
\end{tabular}

Na semeadura foram distribuídas três sementes de milho por cova. Cada caixa comportou quatro covas com espaçamento de $50 \times 30 \mathrm{~cm}$.

Também, por ocasião da semeadura, foi aplicada, na linha de cultivo, a adubação mineral de plantio nos tratamentos testemunha (Tabela 14). Os cálculos foram baseados nas sugestões de Raij \& Cantarella (1996), nas análises de rotina (Tabela 10) e teor de micronutrientes do solo (Tabela 11) e, levando-se em consideração a área da caixa de $0,8825 \mathrm{~m}^{2}$. Os fertilizantes minerais utilizados foram nitrato de amônio, superfosfato simples, cloreto de potássio e sulfato de zinco. Os tratamentos com biossólido receberam somente adubação potássica, pois os teores de $\mathrm{K}$ no solo classificaram-se em baixo no LV e médio no LR. 
Tabela 14. Adubação mineral realizada na semeadura do milho.

\begin{tabular}{ccccc}
\hline Tramentos & $\mathrm{N}$ & $\mathrm{P}$ & $\mathrm{K}$ \\
Fonte: $\mathrm{NH}_{4} \mathrm{NO}_{3}$ & $\begin{array}{c}\text { Fonte: } \\
\text { superfosfato } \\
\text { simples }\end{array}$ & Fonte: $\mathrm{KCl}$ & $\begin{array}{c}\mathrm{Zn} \\
\text { Fonte: } \mathrm{ZnSO}_{4}\end{array}$ \\
\hline LV+lodo & - & - & 33 & - \\
LV & 30 & 44 & 33 & 4 \\
LR+lodo & - & - & 33 & - \\
LR & 30 & 44 & 33 & 4 \\
\hline
\end{tabular}

A emergência das plantas de milho ocorreu cinco dias após a semeadura. Decorridos oito dias da semeadura foi realizado o desbaste, deixando-se uma planta por cova, ou seja, quatro plantas por caixa.

Aproximadamente duas semanas após a semeadura começaram a surgir sintomas de deficiência P nas plantas, em todos os tratamentos (Figura 3), apesar da análise de solo do tratamento com biossólido (Tabela 10) ter revelado valores que seriam suficientes para nutrir a cultura (Raij \& Cantarella, 1996). Assim, aplicou-se em cobertura nos tratamentos com biossólido $54,62 \mathrm{~kg} \mathrm{ha}^{-1}$ de $\mathrm{P}$ e, nos tratamentos testemunha, $10 \mathrm{~kg} \mathrm{ha}^{-1}$ de $\mathrm{P}$. Nesta ocasião, as plantas também foram atacadas por Spodoptera furgiperda. Para combater a praga, pulverizou-se Lufenuron ( $40 \mathrm{mg}$ i.a. $\mathrm{L}^{-1}$ de água). 


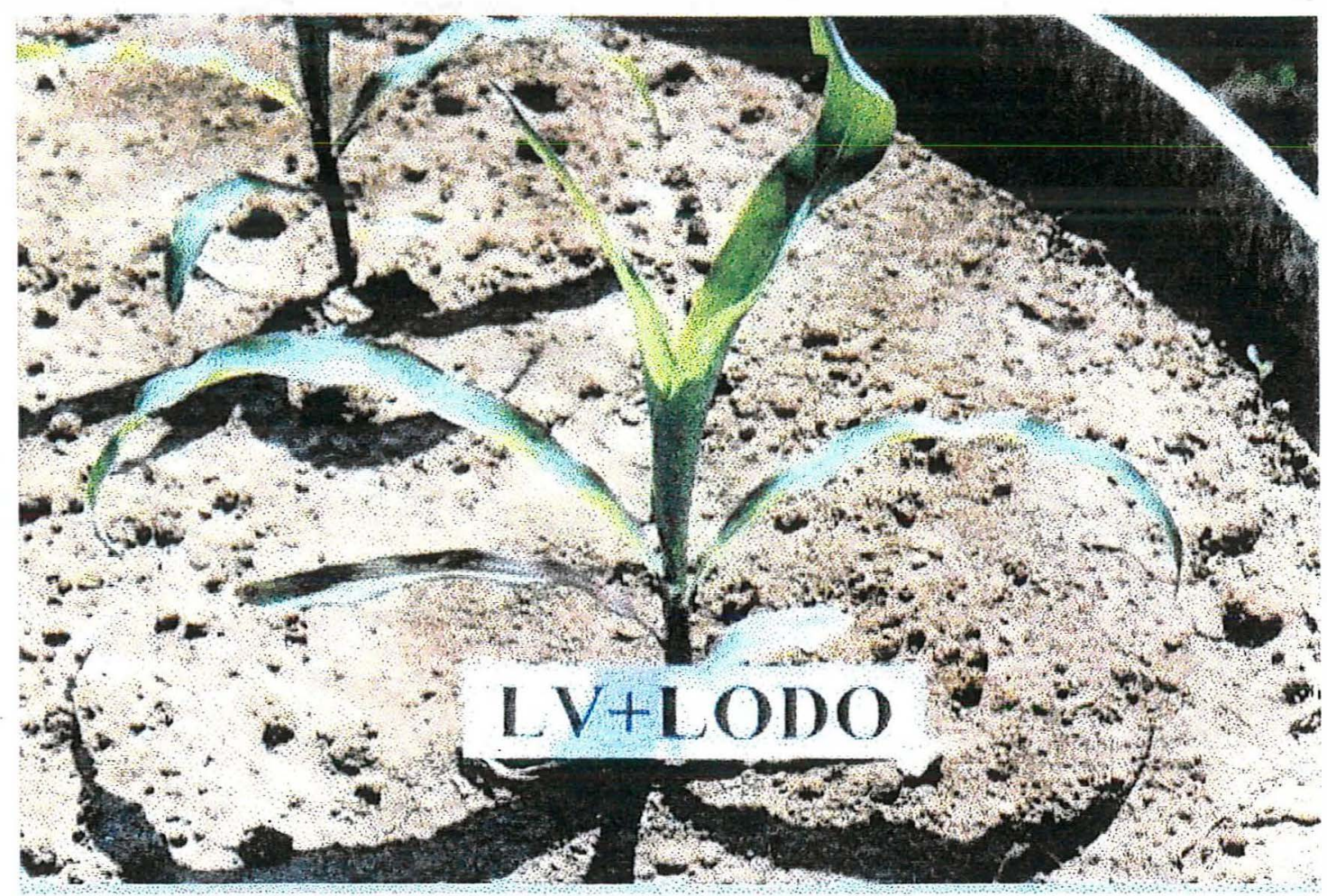

Figura 3 - Sintoma de deficiência de P no tratamento LV+lodo.

Quando as plantas de milho apresentavam a quarta folha, emitindo a quinta folha, 21 dias após a semeadura, foi realizada a primeira adubação mineral de cobertura com $\mathrm{N}$, porque as plantas já apresentavam sintomas de deficiência de N (Figura 4), junto como a adubação com $\mathrm{K}$ em todos os tratamentos, incluindo com biossólido (Tabela 15). A adubação mineral de cobertura de $\mathrm{N}$ e $\mathrm{K}$ também foi realizada com base nas sugestões de Raij \& Cantarella (1996) e na análise de rotina da terra (Tabela 10). A quantidade recomendada de $\mathrm{N}$ foi parcelada em duas aplicações, enquanto que a de $\mathrm{K}$ foi aplicada em uma única dose. A segunda adubação de $\mathrm{N}$ em cobertura foi realizada com as plantas de milho apresentando nove folhas, aproximadamente cinco semanas após a semeadura (Tabela 15). O aspecto geral das plantas no estádio 3 (plantas com oito folhas) pode ser visto na Figura 5. 


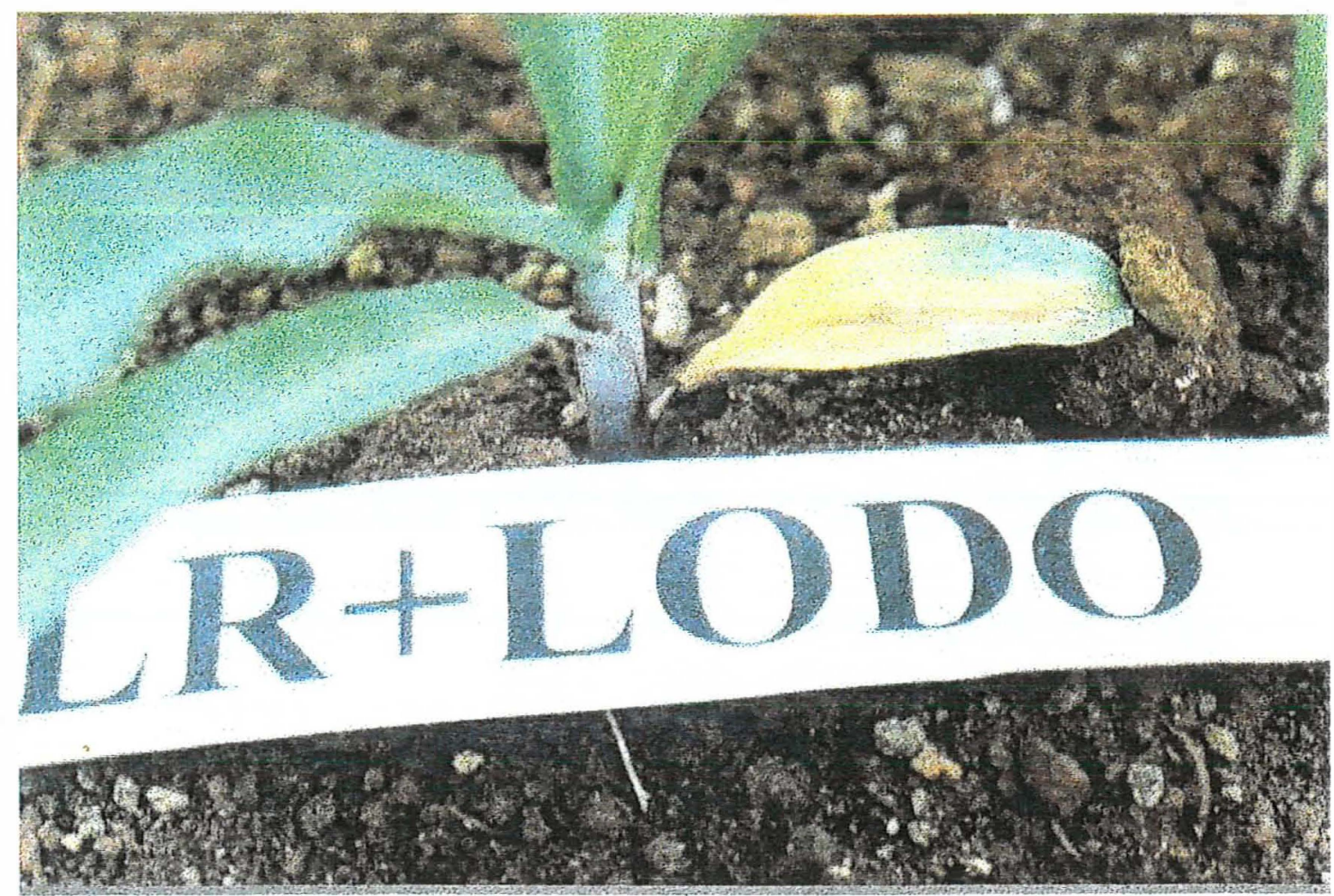

Figura 4 - Sintoma de deficiência de N no tratamento LR+lodo.

Uma semana antes da última adubação de $\mathrm{N}$ houve um novo ataque de Spodoptera furgiperda, sendo necessária uma nova aplicação de Lufenuron (40 mg i.a. $\mathrm{L}^{-1}$ de água).

Tabela 15. Adubação mineral de cobertura da cultura do milho.

\begin{tabular}{cccc}
\hline & \multicolumn{2}{c}{$\mathrm{N}$} & $\mathrm{K}$ \\
& \multicolumn{2}{c}{ Fonte: $\mathrm{NH}_{4} \mathrm{NO}_{3}$} & Fonte: $\mathrm{KCl}$ \\
& $4^{2}$ para $5^{\circ}$ folha & $9^{\circ}$ folha & $4^{*}$ para 5 folha \\
\hline LV+lodo & 85 & 55 & 33 \\
LV & 55 & 55 & 33 \\
LR+lodo & 85 & 55 & 33 \\
LR & 55 & 55 & 33 \\
\hline
\end{tabular}


Durante o desenvolvimento da cultura de milho foram feitas medidas semanais da altura das plantas e do diâmetro dos colmos, iniciadas 19 dias após a semeadura, ocasião em que as plantas apresentavam a quarta folha. Ao todo foram realizadas 15 determinações. Este procedimento foi realizado com a finalidade de se acompanhar o desenvolvimento das plantas. Neste período também ocorreu a coleta e armazenamento das folhas mais velhas. Nos meses de novembro de 1997, janeiro e fevereiro de 1998, foi necessário irrigar várias vezes a cultura com $8 \mathrm{~L}$, de água caixa ${ }^{-1}$, devido à falta de chuva (Tabela 16 e Apêndices 2.4 e 2.5 ).

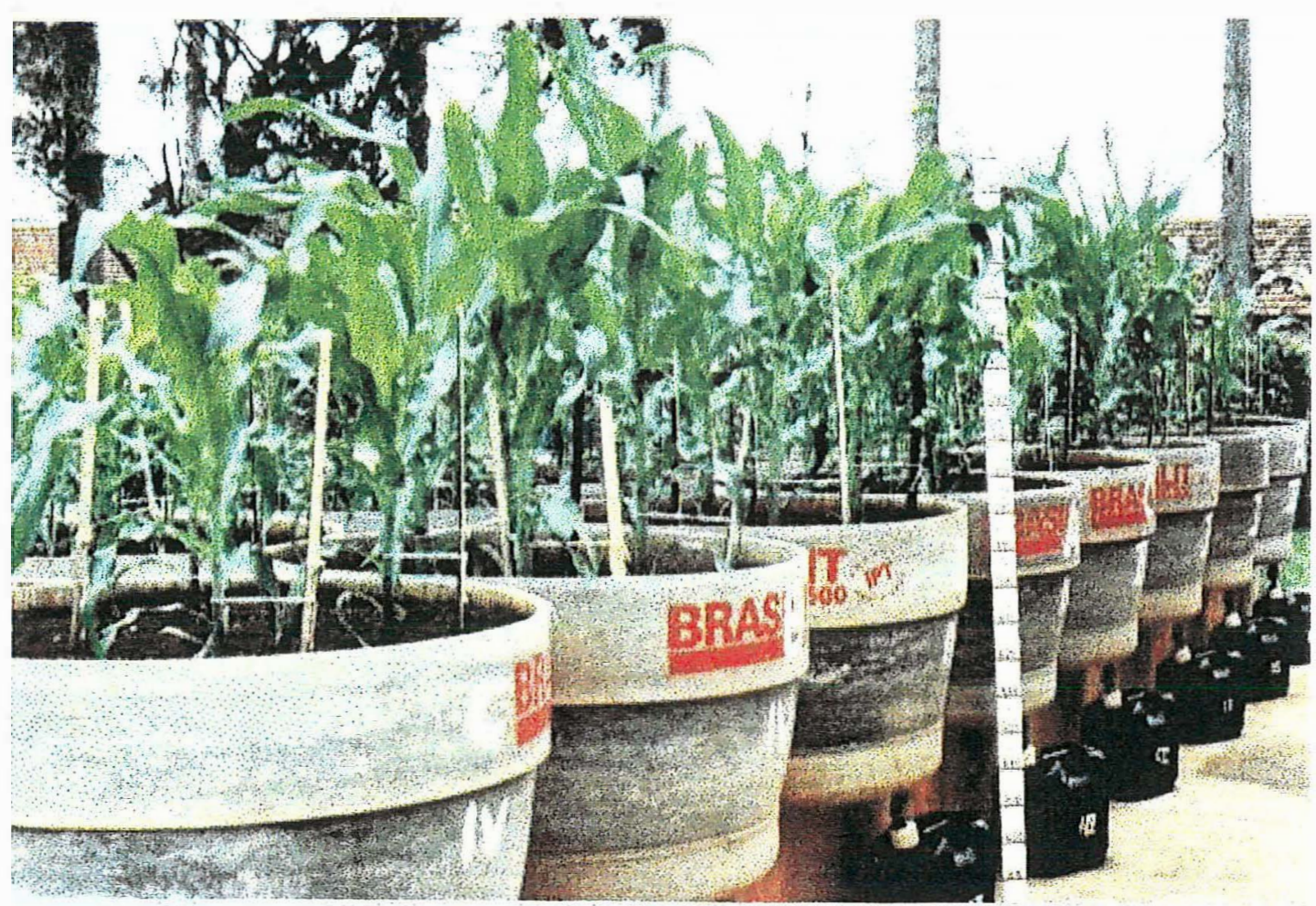

Figura 5 - Aspecto geral da cultura de milho, com as plantas no estádio 3 (8 folhas).

Quando 50\% das plantas apresentavam pendoamento, aproximadamente dois meses após a semeadura, foi coletado o terço médio da folha da base da espiga (folha diagnose) das plantas de milho, de cada parcela experimental.

Decorridos 99 dias após a semeadura foram colhidas as plantas de milho dos 
tratamentos testemunha, por se encontrarem no ponto de maturidade fisiológica, enquanto que as plantas dos tratamentos com biossólido foram colhidas decorridos 119 dias.

As plantas de milho foram separadas em pendão, folhas, colmo, bainha, grãos, sabugo e palha que envolve a espiga. Os pendões, grãos e sabugos foram postos diretamente para secar em estufa a $60^{\circ} \mathrm{C}$ até peso constante, enquanto que os demais materiais vegetais, inclusive as folhas da base da espiga (folha diagnose), anteriormente colhidas, foram lavados com água corrente, solução de $\mathrm{HCl} 0,1 \mathrm{~mol} \mathrm{~L}^{-1}$ e com água destilada, sendo posteriormente postos para secar em estufa. Após a secagem, ocorreu a quantificação da matéria seca. Determinou-se percentagem de água dos grãos para corrigir os valores de produtividade para a umidade de $13 \%$. Posteriormente todos esses materiais vegetais foram submetidos a digestão nitro-perclórica (Sarruge \& Haag, 1974), sendo determinados, nos extratos, os teores dos metais $\mathrm{Cd}, \mathrm{Cu}, \mathrm{Cr}, \mathrm{Ni}, \mathrm{Pb}, \mathrm{Zn}$ e $\mathrm{Mn}$ por espectrofotometria de absorção atômica convencional, com chama. A parte foliar (folhas ao final do ciclo da cultura e a folha diagnose) além de ser submetida a digestão nitroperclórica foi submetida a digestão sulfúrica (Sarruge \& Haag, 1974), sendo determinado nos extratos os teores de $\mathrm{N}$ pelo método microkjeldahl.

A Tabela 16 apresenta um cronograma dos tratos culturais realizados durante o desenvolvimento da cultura de milho. 
Tabela 16. Período de realização dos tratos culturais da cultura do milho.

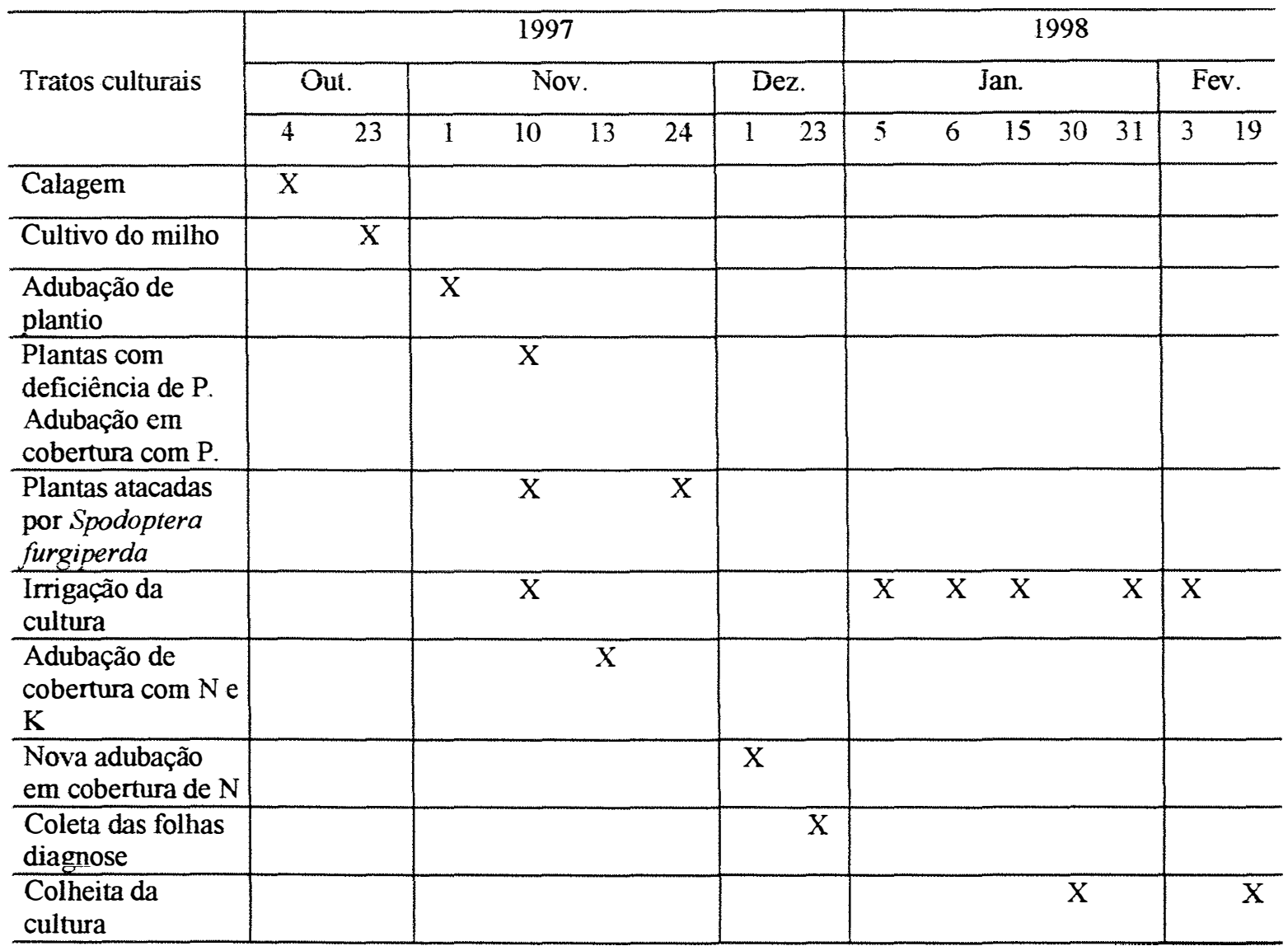

\subsubsection{Avaliação de métodos de extração}

Visando observar a correspondência entre a absorção de metais pelas plantas com os teores destes determinados nas amostras de terra coletadas antes do cultivo do milho, foram preparados extratos de terra com:

a) $\mathrm{HCl} \mathrm{0,1} \mathrm{mol} \mathrm{L}{ }^{-1}$, seguindo a metodologia adaptada de Page et al. (1982). Adicionou-se $50 \mathrm{~mL}$ de solução $\mathrm{HCl} 0,1 \mathrm{~mol} \mathrm{~L}^{-1}$ à $10,0 \mathrm{~g}$ de TFSA, deixou-se em repouso por 24 horas e filtrou-se a suspensão solo/solução extratora em papel de filtro Whatman $\mathrm{n}^{0} 1$.

b) Mehlich 3. De acordo com Mehlich (1984), 5,0 g de TFSA foram agitados, durante cinco minutos, com $50 \mathrm{~mL}$ da solução extratora Mehlich 3. Esta agitação foi 
realizada em agitador circular horizontal com rotação de $240 \mathrm{rpm}$. A seguir, a suspensão solo/solução extratora foi filtrada em papel de filtro Whatman $\mathrm{n}^{0} 1$.

Preparo da solução extratora: em balão volumétrico de $2 \mathrm{~L}$ adicionou-se $200 \mathrm{~mL}$ $\mathrm{NH}_{4} \mathrm{NO}_{3} 2,5 \mathrm{~mol} \mathrm{~L}^{-1}, 8 \mathrm{~mL}$ Fluoreto/EDTA $\left(\mathrm{NH}_{4} \mathrm{~F} \mathrm{3,75 \textrm {mol } \mathrm { L } ^ { - 1 } + \text { EDTA 0,25 mol L}}{ }^{-1}\right)$, $23 \mathrm{~mL}$ de ácido acético glacial concentrado e $1,8 \mathrm{~mL}$ de ácido nítico concentrado. $\mathrm{O} \mathrm{pH}$ desta solução foi ajustado para 2,5 com solução de $\mathrm{NH}_{3}$.

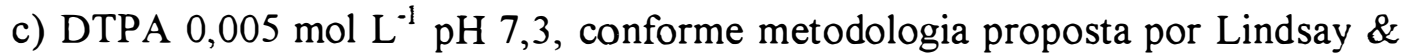
Norvell (1978). Agitou-se por por 2 horas, em agitador mecânico numa rotação de 240 rpm, 20,0 g de TFSA com $40 \mathrm{~mL}$ de solução extratora (DTPA 0,005 $\mathrm{mol} \mathrm{L}^{-1}+$ trietanolamina $0,1 \mathrm{~mol} \mathrm{~L}^{-1}+\mathrm{CaCl}_{2} 0,01 \mathrm{~mol} \mathrm{~L}^{-1}$, corrigidos a $\mathrm{pH} 7,3$ ). Filtrou-se a suspensão solo/solução extratora em papel de filtro Whatman $\mathrm{n}^{0} 1$.

d) Água régia, de acordo com a metodologia estabelecida por Abreu et al. (1996). A extração em microondas com água régia foi realizada adicionando-se $0,5000 \mathrm{~g}$ de amostra em tubos de teflon juntamente com $16 \mathrm{~mL}$ de água régia $(12 \mathrm{~mL}$ de $\mathrm{HCl} 37 \%$ e $4 \mathrm{~mL} \mathrm{HNO}_{3} 65 \%$ ). A seguir os tubos foram fechados e agitados para a eliminação do $\mathrm{CO}_{2}$. O programa do microondas consistiu de 3 etapas: $1^{\underline{a}}$ ) força de $30 \%$ por 1 minuto com pressão de $276 \mathrm{kPa}\left(40 \mathrm{lb} \mathrm{pol}^{-2}\right)$; $2^{\mathrm{a}}$ ) força de $80 \%$ por 4 minutos com pressão de $554 \mathrm{kPa}\left(80 \mathrm{lb} \mathrm{pol}^{-2}\right)$; e $\left.3^{\text {a }}\right)$ força de 100 por 60 minutos com pressão de 692 $\mathrm{kPa}\left(100 \mathrm{lb} \mathrm{pol}^{-2}\right)$. Os extratos de terra foram transferidos para balões volumétricos de 50 $\mathrm{mL}$, sendo a suspensão filtrada em papel de filtro Whatman $\mathrm{n}^{-} 1$.

Após a filtragem todos os extratos de terra foram submetidos à leitura dos teores de $\mathrm{Cd}, \mathrm{Cr}, \mathrm{Cu}, \mathrm{Mn}, \mathrm{Ni}, \mathrm{Pb}$ e $\mathrm{Zn}$ por espectrofotometria de absorção atômica convencional, com chama.

\subsection{Tratamento estatístico dos resultados}

O tratamento estatístico foi realizado nas seguintes variáveis referentes à àgua lixiviada:

$-\mathrm{pH}$ 
- Condutividade elétrica;

- Água lixiviada;

- K; $\mathrm{Ca} ; \mathrm{Mg}$;

- Metais:

. Cd, $\mathrm{Cu}, \mathrm{Cr}, \mathrm{Mn}, \mathrm{Ni}$ e Zn;

$-\mathrm{N}-\mathrm{NO}_{3}{ }^{\circ}$.

As variáveis estudadas no solo foram:

- $\mathrm{pH}$;

- Condutividade elétrica;

- K; Ca; Mg;

- $\mathrm{Cr}, \mathrm{Cu}, \mathrm{Mn}, \mathrm{Ni}$ e $\mathrm{Zn}$ removidos por:

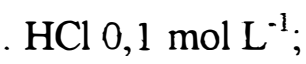

. Mehlich 3;

. DTPA pH 7,3;

. Água régia (teor total).

As variáveis estudadas no planta foram:

- Produtividade;

- Diâmetro do colmo;

- Altura da planta;

- Matéria seca total que envolveu as seguintes partes da planta:

bainha; colmo; folha diagnose (FD); folhas ao final do ciclo da cultura (FF); grão; palha; sabugo e pendão.

- Teores de:

Cu na bainha, no colmo, na FD, na FF, no grão, na palha e no sabugo;

Cr no sabugo;

. Mn na bainha, no colmo, na FD, na FF, no grão, na palha e no sabugo;

Zn na bainha, no colmo, na FD, na FF, no grão, na palha e no sabugo;

. N na FD e na FF; 
- Quantidade total absorvida de:

Cu na bainha, no colmo, na FD, na FF, no grão, na palha e no sabugo;

Cr no sabugo;

Mn na bainha, no colmo, na FD, na FF, no grão, na palha e no sabugo;

Zn na bainha, no colmo, na FD, na FF, no grão, na palha e no sabugo;

$\mathrm{N}$ na FD e na FF.

As análises estatísticas para $\mathrm{pH}$, condutividade, $\mathrm{K}, \mathrm{Ca}$ e $\mathrm{Mg}$, na água lixiviada e na terra, bem como para $\mathrm{N}_{-} \mathrm{NO}_{3}{ }^{-}$na água lixiviada e quantidade de água lixiviada, seguiram o delineamento em blocos completos casualizados, com quatro repetições e com quatro tratamentos ( $\mathrm{LV}+$ lodo, $\mathrm{LV}, \mathrm{LR}+$ lodo, $\mathrm{LR}$ ), subdividindo-se as parcelas em aplicações. O esquema para análise da variância é apresentado na Tabela 17 (Steel \& Torrie, 1960; Gomes, 1987).

Tabela 17. Esquema de análise da variância e teste $\mathrm{F}$ para delineamento em blocos com parcelas subdivididas.

\begin{tabular}{lcccc}
\hline \multicolumn{1}{c}{ Causas da Variação } & G.L. & S.Q. & Q.M. & F \\
\hline Blocos & 3 & SQ Blocos & QM Blocos & \\
Tratamentos & 3 & SQ Tratamentos & QM Tratamentos & QM Trat./QM Resíduo(A) \\
Resíduo (A) & 9 & SQ Resíduo (A) & QM Resíduo (A) & \\
\hline Parcelas) & $(15)$ & & & \\
Aplicações & 4 & SQ Aplicações & QM Aplicações & QM Aplic./QM Resíduo(B) \\
Tratamentos x Aplicações & 12 & SQ Trat. x Aplic. & QM Trat. x Aplic. & QM Trat.xAplic/QM Res.(B) \\
Resíduo (B) & 48 & SQ Resíduo (B) & QM Resíduo (B) & \\
\hline Total & 79 & SQ Total & & \\
\hline
\end{tabular}

onde S.Q. (somas de quadrados) e Q.M. (quadrados médios) podem ser obtidos em literatura da área.

A razão QM (Causas da Variação)/QM Resíduo testa a hipótese:

$\mathrm{H}_{0}$ : não existe diferença entre as médias de Tratamentos (QM Trat./QM Resíduo).

$\mathrm{H}_{0}$ : não existe diferença entre as médias de Aplicações (QM Aplic./QM Resíduo). 
Considerou-se como nível mínimo para rejeição das hipóteses $5 \%$, ou seja, sempre que o valor da probabilidade do teste $F$ for menor ou igual a $0,05(\alpha \leq 0,05)$ não se rejeita que há diferença significativa entre pelo menos duas médias de tratamentos ou aplicações, e procede-se então ao detalhamento da análise.

Dado que, a priori, foi determinado 2 grupos de tratamentos, com e sem biossólido, sempre que o teste $\mathrm{F}$ detectou diferença significativa entre duas médias de tratamentos, foi feito o desdobramento dos graus de liberdade de tratamentos em 3 contrastes ortogonais:

$$
\begin{aligned}
& \mathrm{Y}_{1}=\text { Com lodo vs sem lodo }=(\mathrm{T} 1+\mathrm{T} 3)-(\mathrm{T} 2+\mathrm{T} 4) \\
& \mathrm{Y}_{2}=\text { Entre as duas amostras de terra, com lodo }=\mathrm{T} 1-\mathrm{T} 3 ; \\
& \mathrm{Y}_{3}=\text { Entre as duas amostras de terra, sem lodo }=\mathrm{T} 2-\mathrm{T} 4 ;
\end{aligned}
$$

cujo esquema é apresentado na Tabela 18.

Tabela 18. Esquema do desdobramento dos graus de liberdade de tratamentos em contrastes ortogonais e teste $\mathrm{F}$.

\begin{tabular}{lcccc}
\hline \multicolumn{1}{c}{ Causas da Variação } & G.L. & S.Q. & Q.M. & F \\
\hline Com lodo vs Sem lodo $\left(\mathrm{Y}_{1}\right)$ & 1 & SQ $\left(\mathrm{Y}_{1}\right)$ & QM $\left(\mathrm{Y}_{1}\right)$ & QM $\left(\mathrm{Y}_{1}\right) /$ Residuo \\
LV vs LR, Com lodo $\left(\mathrm{Y}_{2}\right)$ & 1 & SQ $\left(\mathrm{Y}_{2}\right)$ & $\mathrm{QM}\left(\mathrm{Y}_{2}\right)$ & $\mathrm{QM}\left(\mathrm{Y}_{2}\right) /$ Resíduo \\
LV vs LR, Sem lodo $\left(\mathrm{Y}_{3}\right)$ & 1 & SQ $\left(\mathrm{Y}_{3}\right)$ & $\mathrm{QM}\left(\mathrm{Y}_{3}\right)$ & $\mathrm{QM}\left(\mathrm{Y}_{3}\right) /$ Resíduo \\
Resíduo & 9 & SQ Resíduo & QM Resíduo & \\
\hline
\end{tabular}

e, se detectada diferença significativa para o contraste, a decisão sobre o resultado é tomada através do sinal do contraste. Por exemplo, supondo-se que o contraste $n^{\circ} 1$ seja significativo e que a soma das médias de $\mathrm{T} 1+\mathrm{T} 3$ seja maior que a soma das médias de $\mathrm{T} 2+\mathrm{T} 4$, infere-se que, ao nível de significância detectado, os tratamentos com biossólido superam os sem biossólido, para essa variável.

Para o fator Aplicações, sempre que foi detectada diferença significativa pelo teste $\mathrm{F}$, foi realizado o detalhamento da análise através do teste de Tukey, considerandose como nível mínimo de significância de 5\%.

Também foi feito estudo de correlação linear (dos resíduos) entre as variáveis 
$\mathrm{pH}$, condutividade, $\mathrm{K}, \mathrm{Ca}$ e $\mathrm{Mg}$ encontradas na água lixiviada e na terra.

Para as variáveis $\mathrm{Cu}, \mathrm{Mn}$ e $\mathrm{Zn}$ medidas pelos extratores (métodos de extração), a análise da variância seguiu o delineamento em blocos casualizados completos, com quatro repetições e com os mesmos quatro tratamentos de terra, acrescentando-se agora os métodos de extração, que formaram, junto com os tratamentos de terra um esquema fatorial. O esquema para análise é apresentado na Tabela 19 (Steel \& Torrie, 1960; Gomes, 1987).

Tabela 19. Esquema de análise da variância e teste $\mathrm{F}$ para delineamento em blocos com fatorial.

\begin{tabular}{lcccc}
\hline \multicolumn{1}{c}{ Causas da Variação } & G.L. & S.Q. & Q.M. & F \\
\hline Blocos & 3 & SQ Blocos & QM Blocos & \\
Métodos & 3 & SQ Métodos & QM Métodos & QM Métodos./QM Resíduo \\
Tratamentos & 3 & SQ Tratamentos & QM Tratamentos & QM Trat./QM Resíduo \\
Métodos x Tratamentos & 9 & SQ Mét. x Trat. & QM Mét. x Trat. & QM Mét.x Trat./QM Resíduo \\
Resíduo & 45 & SQ Resíduo & QM Resíduo & \\
\hline Total & 63 & SQ Total & & \\
\hline
\end{tabular}

Sempre que o teste $\mathrm{F}$ detectou diferença significativa entre os tratamentos, procedeu-se aos desdobramentos dos g.1. em contrastes ortogonais, como no caso anterior (Tabela 18). Já para o fator Métodos, sempre que foi detectada diferença significativa pelo teste $\mathrm{F}$, foi feito o detalhamento da análise através do teste de Tukey, considerando-se como nível mínimo de significância de $5 \%$.

Como os resultados referentes a remoção de $\mathrm{Cd}, \mathrm{Cr}$ e Ni pelos diversos extratores estiveram abaixo do limite de deteç̧ão do método analítico empregado nos tratamentos onde não se aplicou biossólido, somente puderam ser analisados os tratamentos que receberam biossólido. Desta forma, a análise da variância seguiu delineamento idêntico ao mencionado anteriormente, diferindo apenas nos G.L. dos Tratamentos $(G . L=1)$, Métodos $x$ Tratamentos (G.L.=3), Resíduo $(G . L .=21)$ e Total $(G . L .=31)$.

Para essas variáveis, sempre que o teste $\mathrm{F}$ detectou diferença significativa entre 
os Tratamentos, Métodos e interação Métodos x Tratamentos, o detalhamento da análise foi realizado através do teste de Tukey, considerando-se como nível mínimo de significância de $5 \%$.

Complementando essas análises foi feito um estudo de correlação linear (dos resíduos) entre os metais $\mathrm{Cr}, \mathrm{Cu}, \mathrm{Mn}$ e $\mathrm{Zn}$ removidos da terra pelos diversos extratores e estes mesmos metais encontrados nas diversas partes da planta de milho.

A análise estatística da variável produtividade baseou-se em um delineamento em blocos completos casualizados, com quatro repetições, média de quatro plantas por parcela, quatro tratamentos (LV+lodo, LV, LR+lodo, LR), cujo esquema é apresentado na Tabela 20 (Steel \& Torrie, 1960; Gomes, 1987).

Tabela 20. Esquema de análise da variância e teste $\mathrm{F}$ para o delineamento em blocos ao acaso.

\begin{tabular}{lcccc}
\hline \multicolumn{1}{c}{ Causas da Variação } & G.L. & S.Q. & Q.M. & F \\
\hline Blocos & 3 & SQ Blocos & QM Blocos & \\
Tratamentos & 3 & SQ Tratamentos & QM Tratamentos & QM Trat./QM Resíduo \\
Resíduo & 9 & SQ Resíduo & QM Resíduo & \\
\hline Total & 15 & SQ Total & & \\
\hline
\end{tabular}

Sempre que o teste $\mathrm{F}$ detectou diferença significativa entre os tratamentos, procedeu-se aos desdobramentos dos g.l. em contrastes ortogonais, como nos casos anteriores (Tabela 18).

As análises estatísticas para as variáveis diâmetro do colmo e altura do milho fundamentaram-se em um delineamento em blocos completos casualizados, com quatro repetições e média de quatro plantas por parcela, com quatro tratamentos ( $\mathrm{LV}+$ lodo, $\mathrm{LV}$, LR+lodo, LR), subdividindo-se as parcelas em épocas de medição. A parcela foi originalmente subdividida em 15 épocas, no entanto as parcelas que não receberam biossólido foram colhidas na época 13, enquanto que as restantes continuaram no experimento. Porém, uma análise dos dados das três últimas épocas permitiu inferir que as plantas já estavam na fase de senescência, onde os crescimentos de diâmetros e 
alturas estabilizaram-se, não acrescentando, portanto, informação relevante aos objetivos da pesquisa. Diante disto, considerou-se a parcela subdividida em 12 épocas.

O esquema de análise da variância para essas variáveis foi o mesmo utilizado para as varíaveis determinadas na água lixiviada (Tabela 17).

Sempre que o teste $\mathrm{F}$ detectou diferença significativa entre os tratamentos, procedeu-se ao desdobramentos dos g.l. em contrastes ortogonais, como nos casos anteriores (Tabela 18). Já para o fator Épocas, sempre que foi detectada diferença significativa pelo teste $\mathrm{F}$, foi feita análise de regressão polinomial para procurar $\mathrm{o}$ melhor ajuste para explicar o comportamento das variáveis no decorrer do tempo ${ }^{1}$.

As análises estatísticas das variáveis matéria seca total, teores e quantidades totais absorvidas de metais nas partes das plantas e teores e quantidades totais absorvidas de $\mathrm{N}$ nas folhas foram realizadas com base em um delineamento em blocos completos casualizados, com quatro repetições e média de quatro plantas por parcela, quatro tratamentos ( $\mathrm{LV}+$ lodo, LV, LR+lodo, LR), seguindo o mesmo esquema e detalhamento de análise utilizados para produtividade (Tabelas 20 e 18, respectivamente).

Complementarmente foi feito um estudo de correlação linear (dos resíduos) entre a produtividade e os teores e quantidades absorvidas de metais nas partes da planta.

\subsubsection{Análise exploratória dos dados}

Para que os modelos de análise descritos tenham validade e os testes tenham poder, são necessárias serem satisfeitas as pressuposições:

- homogeneidade de variâncias, ou seja, só podem ser comparados tratamentos com variâncias homogêneas entre si;

- independência dos erros;

- erros (variação do acaso) com distribuição normal (ou aproximadamente normal).

Para testar essas pressuposições procedeu-se à análise exploratória de dados,

\footnotetext{
${ }^{1}$ Não pode ser utilizado para esse caso testes qualitativos para escolher "a melhor" ou a "pior" época. Pode-se apenas estudar como se comporta a variável "no decorrer" das Épocas. Uma justificativa mais teórica pode ser obtida na Estatística Matemática. que mostra que a esperança de uma variável contínua num ponto (um determinado valor) é zero. Exemplo: a probabilidade de uma pessoa medir exatamente
} 
através de:

- Teste de homogeneidade de variâncias: utilizou-se o teste de Levene (Souza, 1998), que consiste em processaĩ uma análise da variância do modelo proposto para análise dos dados, tomando-se como variável o valor absoluto dos resíduos padronizados. As mesmas hipóteses anteriores são testadas pelo teste F. Se o valor obtido for maior que o tabelado, rejeita-se a hipótese de que as variâncias de tratamentos são homogêneas, havendo necessidade de se estudar se essa heterogeneidade pode ser eliminada com uma transformação dos dados ou não. Se o valor obtido for menor que o tabelado, não se rejeita a hipótese de homogeneidade de variâncias (considerou-se como n.m.s. 5\%).

- Análise gráfica dos resíduos: consiste em plotar num diagrama de dispersão os valores estimados pelo modelo da análise da variância versus os resíduos padronizados (erro referente a cada observação dividido pelo desvio padrão amostral). A forma desse gráfico permite a detecção falta de independência e existência de heterogeneidade regular (que pode ser eliminada através do uso de uma transformação adequada) ou irregular (que não permite transformação). $O$ intervalo dos resíduos padronizados detecta se há algum(uns) valor(es) desviandose da normalidade. Consideram-se normalmente distribuídos os resíduos que estiverem no intervalo de -3 a 3.

$\mathrm{O}$ teste de Levene indicou homogeneidade de variâncias para algumas variáveis e heterogeneidade para outras. Para as variáveis nas quais foram detectada heterogeneidade, procedeu-se a um estudo para se verificar se a heterogeneidade encontrada era regular (podendo ser transformada) ou irregular, o que sugeriu que essas variáveis deveriam ser analisadas com as transformações seguintes (Hoaglin et al., 1992).

As variáveis referentes à água lixiviada:

- Condutividade elétrica: $\log (\mathrm{Y})$; 
- $\mathrm{pH}:(\mathrm{Y})^{-2}$;

- Água lixiviada: $\sqrt{Y}$

- K: $\log (\mathrm{Y})$

- Ca e Mg : $\sqrt{Y}$

- N inorgânico: $\log (\mathrm{Y})$.

As variáveis referentes ao solo:

- Condutividade elétrica: $\log (\mathrm{Y})$;

- $\mathrm{pH} \mathrm{CaCl}_{2}$ 0,01 mol L ${ }^{-1}$ : sem transformação;

- $\mathrm{K}: \sqrt{Y}$;

- Ca e Mg: sem transformação;

- $\mathrm{HCl}$ 0,1 $\mathrm{mol} \mathrm{L}^{-1}$; Mehlich 3; DTPA pH 7,3 e água régia:

. $\mathrm{Cu}: \log (\mathrm{Y}+1)$;

. Cd, Cr, Zn e Mn: $\sqrt{Y}$;

. Ni: sem transformação.

Variáveis referentes à planta:

- Produtividade: sem transformação;

- Diâmetro do colmo: $\sqrt{Y}$;

- Altura da planta: $\sqrt{Y}$;

- Matéria seca total: sem transformação;

- Teores de:

$\mathrm{Cr}$

no sabugo: sem transformação;

. $\mathrm{Cu}$

na bainha: $\log (Y)$;

no colmo: $\log (\mathrm{Y})$; 
na FD, na FF, no grão, na palha e no sabugo: sem transformação;

$\mathrm{Mn}$

na bainha, no colmo, na FF, no grão, na palha e no sabugo: sem transformação na FD: $\log (\mathrm{Y})$;

$\mathrm{N}$

na FD e na FF: sem transformação;

$\mathrm{Zn}$

na bainha, no colmo, na FD e na palha: $\log (\mathrm{Y})$;

na FF, no grão e no sabugo: sem transformação;

- Quantidade total absorvida de:

$\mathrm{Cr}$

no sabugo: sem transformação;

$\mathrm{Cu}$

. na bainha, na FD, na FF, no grão e no sabugo: sem transformação;

. no colmo e na palha: $\log (\mathrm{Y})$;

$\mathrm{Mn}$

. na bainha, no colmo, na FD, na FF, no grão e na palha: sem transformação; no sabugo: $\sqrt{Y}$

$\mathrm{N}$

na FD e na FF: sem transformação.

$\mathrm{Zn}$

na bainha, no colmo e palha: $\log (\mathrm{Y})$;

na FD: $1 / \sqrt{Y}$;

na FF, no grão e no sabugo: sem transformação; 


\section{RESULTADOS E DISCUSSÃO}

Este capitulo aborda primeiro os resultados referentes a lixiviação de espécies químicas e a avaliação da disponibilidade dos metais presentes no solo através de extratores e das plantas de milho. Posteriormente, é discutida a influência da aplicação de biossólidos nos caracteres referentes a planta de milho, tais como: produtividade, matéria seca total, diâmetro do colmo e altura.

As análises da variância de todas as variáveis estudas, com os dados transformados de acordo com o descrito na metodologia, e o detalhamento da análise sempre que o teste $\mathrm{F}$ detectou diferença significativa encontram-se nos Apêndices 1, $3 \mathrm{e}$ 4 , enquanto que os gráficos referentes aos valores médios das variáveis analisadas e as correlações estudadas são apresentados neste capítulo.

Ressalta-se que, para as variáveis referentes à água lixiviada e ao solo, bem como para diâmetro do colmo e altura da planta, sempre que houve interação significativa entre dois fatores, o resultado conclusivo foi tomado pelas médias de um fator dentro do outro, porque uma interação significativa indica que o resultado obtido por um fator depende do outro fator. Ou seja, quando a análise da variância detecta interação significativa não se deve concluir sobre cada fator isoladamente. Portanto, só são apresentados os contrates ortogonais ou teste de Tukey para os fatores principais quando a interação entre eles não foi significativa. 


\subsection{Lixiviação das espécies químicas}

\subsubsection{Precipitação}

Durante o período de monitoramento da água lixiviada e de desenvolvimento da cultura de milho observou-se que ocorreram períodos atípicos de precipitação na região de Piracicaba. Nos meses de janeiro, junho, setembro e novembro de 1997 choveu além dos valores pluviométricos normais, apresentando, respectivamente, desvios positivos de 35, 154, 57 e 95\% em relação aos valores normais. Entretanto, nos meses de março, julho, agosto e outubro do mesmo ano e janeiro de 1998 ocorreram desvios negativos de $63,32,40$ e 37 e $38 \%$, respectivamente (Figura 6). A precipitação total no período de monitoramento da água lixiviada foi $1.070 \mathrm{~mm}$ de chuva, enquanto que durante o desenvolvimento da cultura, $814 \mathrm{~mm}$ de chuva.

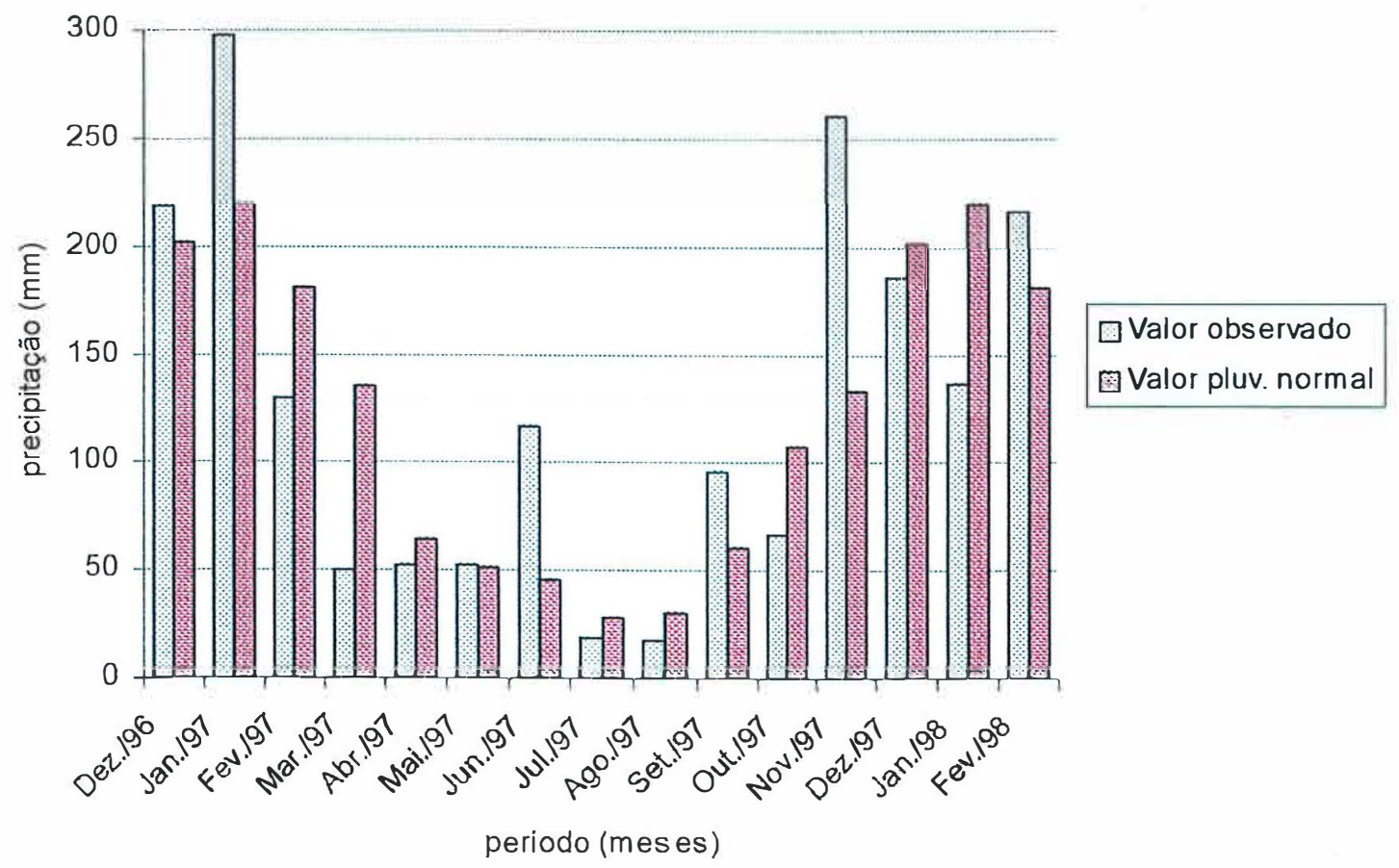

Figura 6 - Comparação dos valores pluviométricos observados durante o monitoramento da água lixiviada e o desenvolvimento da cultura de milho como os valores pluviométricos normais da região de Piracicaba. 


\subsubsection{Quantidade de água lixiviada}

A quantidade de água lixiviada foi significativamente influenciada $(\alpha \leq 0,01)$ pela interação entre os tratamentos e as aplicações de biossólido (Apêndice 1.1).

Somente durante o efeito da terceira e quinta aplicações (Apêndice 1.2 e Figura 7) observou-se que nos tratamentos que receberam biossólido houve maior quantidade de água lixiviada, embora, o período mais chuvoso, $564 \mathrm{~mm}$, tenha ocorrido durante o efeito da primeira aplicação de biossólido e o segundo período mais seco, 132 mm, na quinta aplicação (Apêndice 2).

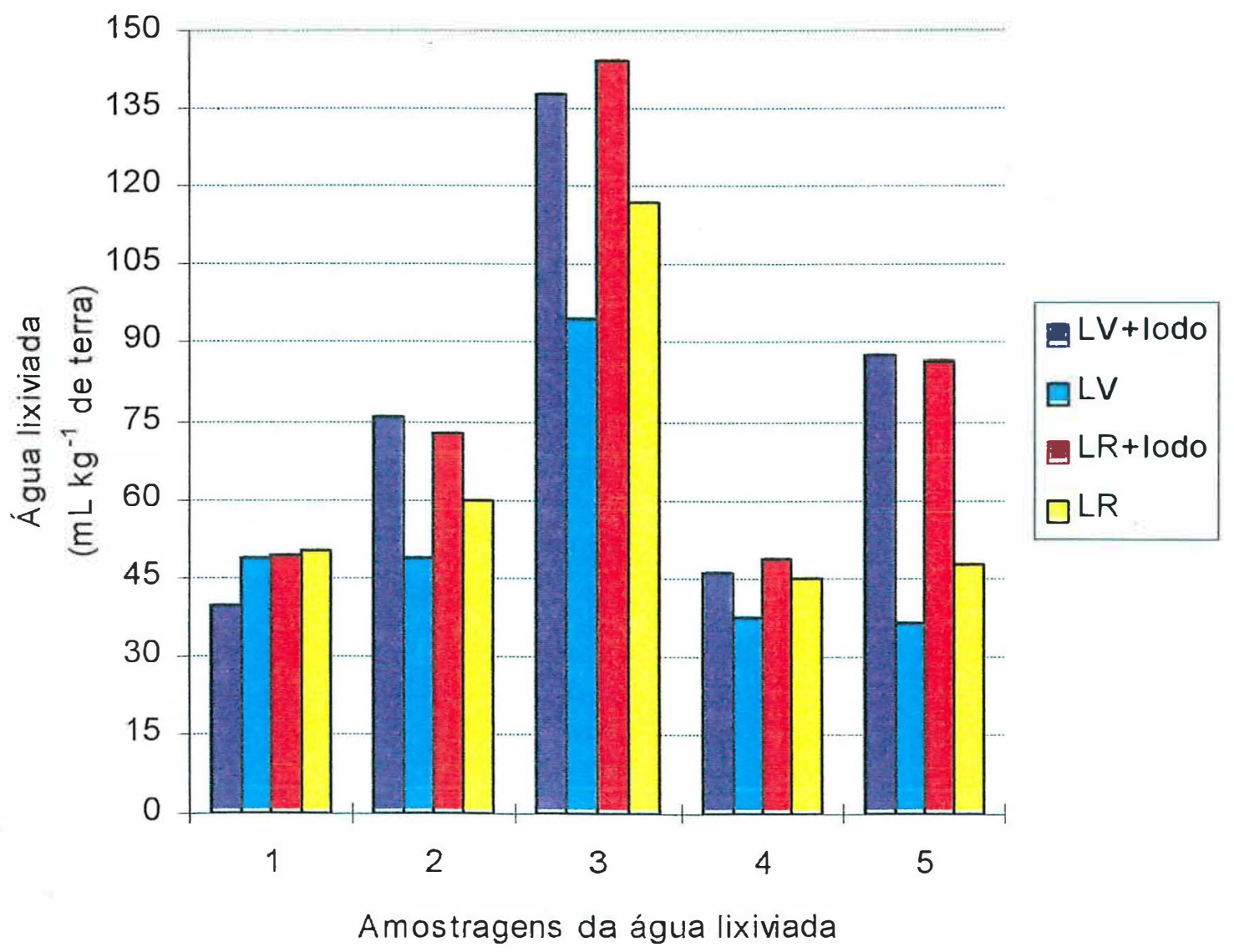

Figura 7 -- Variações na quantidade de água lixiviada em função das aplicações de biossólido. 
Ao se estudar a quantidade de água lixiviada ao longo das aplicações de biossólido e dentro de cada tratamento (Figura 8) verificou-se que em todos os tratamentos, inclusive nos tratamentos testemunha, ocorreu maior lixiviação de água durante o período de efeito da terceira aplicação de biossólido, que foi o segundo período de maior precipitação $(165 \mathrm{~mm})$.

(a)

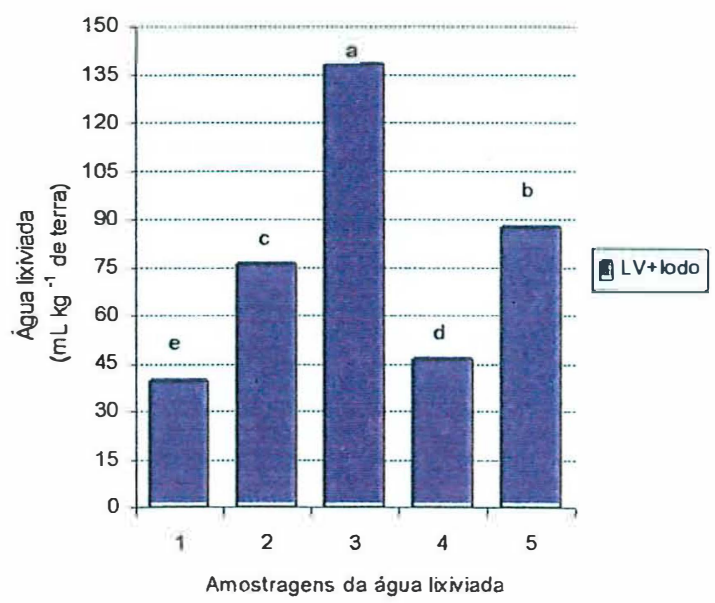

(c)

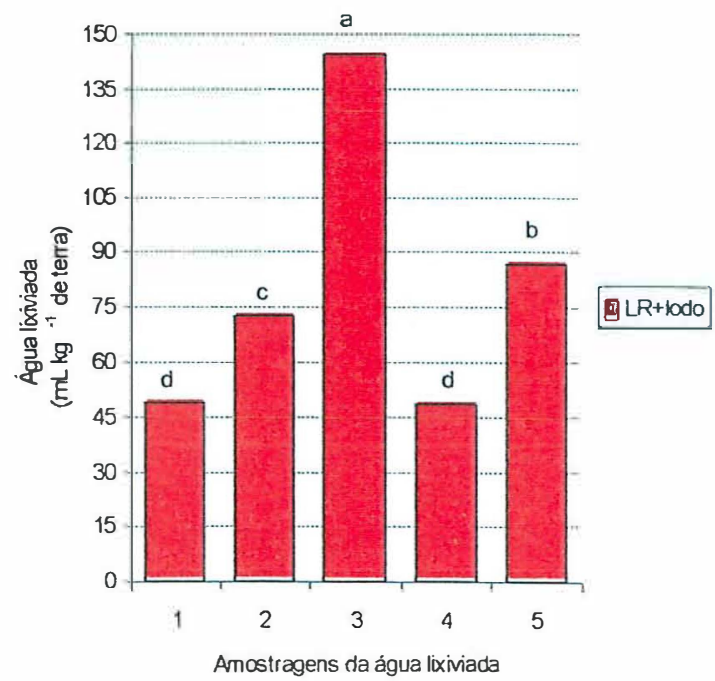

(b)

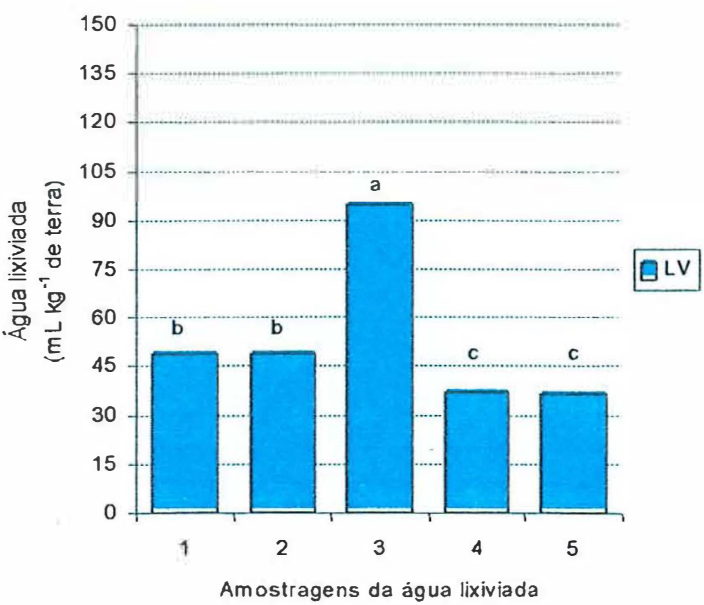

(d)

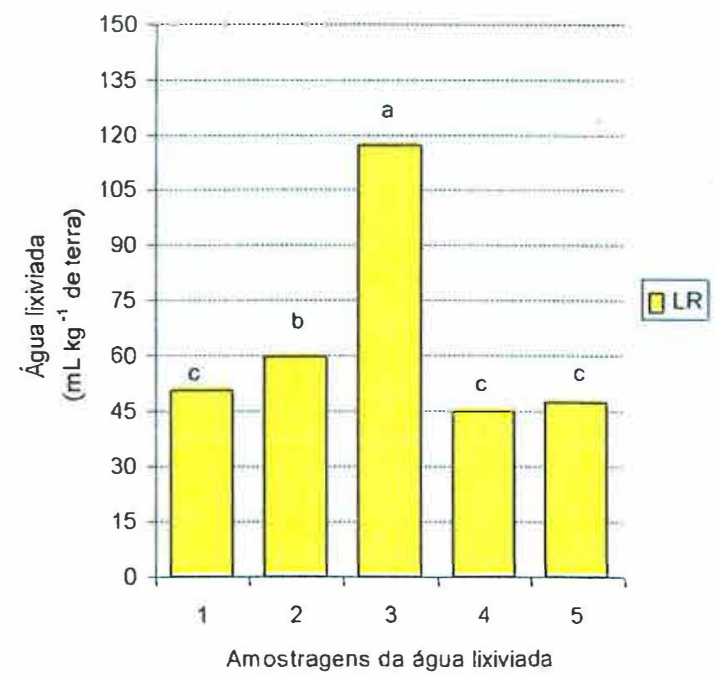

Figura 8 - Variações na quantidade de água lixiviada em função das aplicações de biossólido dentro de cada tratamento. 
Também, constatou-se que, apesar da quantidade de chuva ter sido maior durante o efeito da primeira aplicação de biossólido, ocorreu baixa quantidade de água lixiviada nos tratamentos (Figura 8). Isso deve ter ocorrido porque o solo estava muito seco e as primeiras precipitações serviram para saturá-lo, ocorrendo desta forma pouca drenagem do excesso de água. Nos tratamentos com biossólido (Figura 8a e 8c), esse comportamento foi mais acentuado, provavelmente devido a maior retenção de umidade proporcionada pela presença do resíduo. Epstein (1976) e Wei et al. (1985), ao estudarem o efeito da aplicação de biossólido sobre algumas propriedades fisicas do solo, também constataram aumento no conteúdo e na retenção de água do solo, principalmente após um longo período de seca. No tratamento $\mathrm{LV}$, a quantidade de água lixiviada durante o efeito da primeira aplicação foi equivalente ao da segunda, pois a terra deste tratamento, por ser de textura média, facilitou a drenagem da água.

O efeito benéfico da adição de biossólido, em ambas as amostras de terra (LV e LR), no que diz respeito ao melhoramento da drenagem da água das caixas, pode ser observado durante o efeito da quinta adição de biossólido (Figura 8). Nos tratamentos testemunhas a menor quantidade de água lixiviada foi devida a compactação natural que ocorreu nas amostras de terra contidas nas caixas, pois a densidade era, respectivamente, de 1,29 e $1,09 \mathrm{~g} \mathrm{~cm}^{-3}$ no LV e LR, passando a ser 1,30 e 1,19 $\mathrm{g} \mathrm{cm}^{-3}$. Já, nos tratamentos com biossólido observou-se menor compactação do solo, ou seja, a densidade diminuiu em relação a densidade inicial determinada, passando para $1,22 \mathrm{~g} \mathrm{~cm}^{-3}$ no $\mathrm{LV}+$ lodo e $1,07 \mathrm{~g} \mathrm{~cm}^{-3}$ no LR+lodo, após todas as aplicações de biossólido. Wei et al. (1985) constataram que a aplicação de biossólido aumentou o conteúdo de matéria orgânica do solo, sendo acompanhado por um aumento na estabilidade dos agregados, melhorando desta forma a permeabilidade do solo. Também Jorge et al. (1991) e Logan \& Harrison (1995) observaram que decorrido certo período após a aplicação de biossólido (cerca de 4 e 1 ano, respectivamente) havia um aumento no índice de agregação do solo e na condutividade hidráulica. 


\subsection{3 $\mathrm{pH}$}

$\mathrm{O} \mathrm{pH}$ da água lixiviada e o $\mathrm{pH}$ do solo também foram influenciados pela interação entre os tratamentos e as aplicações de biossólido, sendo comprovado estatisticamente pela significância do teste $\mathrm{F}$ ao nível de $5 \%$ e $1 \%$, respectivamente (Apêndices 1.1 e 3.1, respectivamente).

Ao se comparar os valores médios de $\mathrm{pH}$ da água lixiviada dos tratamentos com e sem biossólido (Apêndice 1.2), verificou-se que a aplicação do resíduo não promoveu a elevação do $\mathrm{pH}$ da água lixiviada, apesar do $\mathrm{pH}$ do solo apresentar uma elevação significativa desde a primeira até a última aplicação, de maneira geral passou de 4,4 para 7,4, em ambas amostras de terra (Apêndice 3.2 e Figura 9).

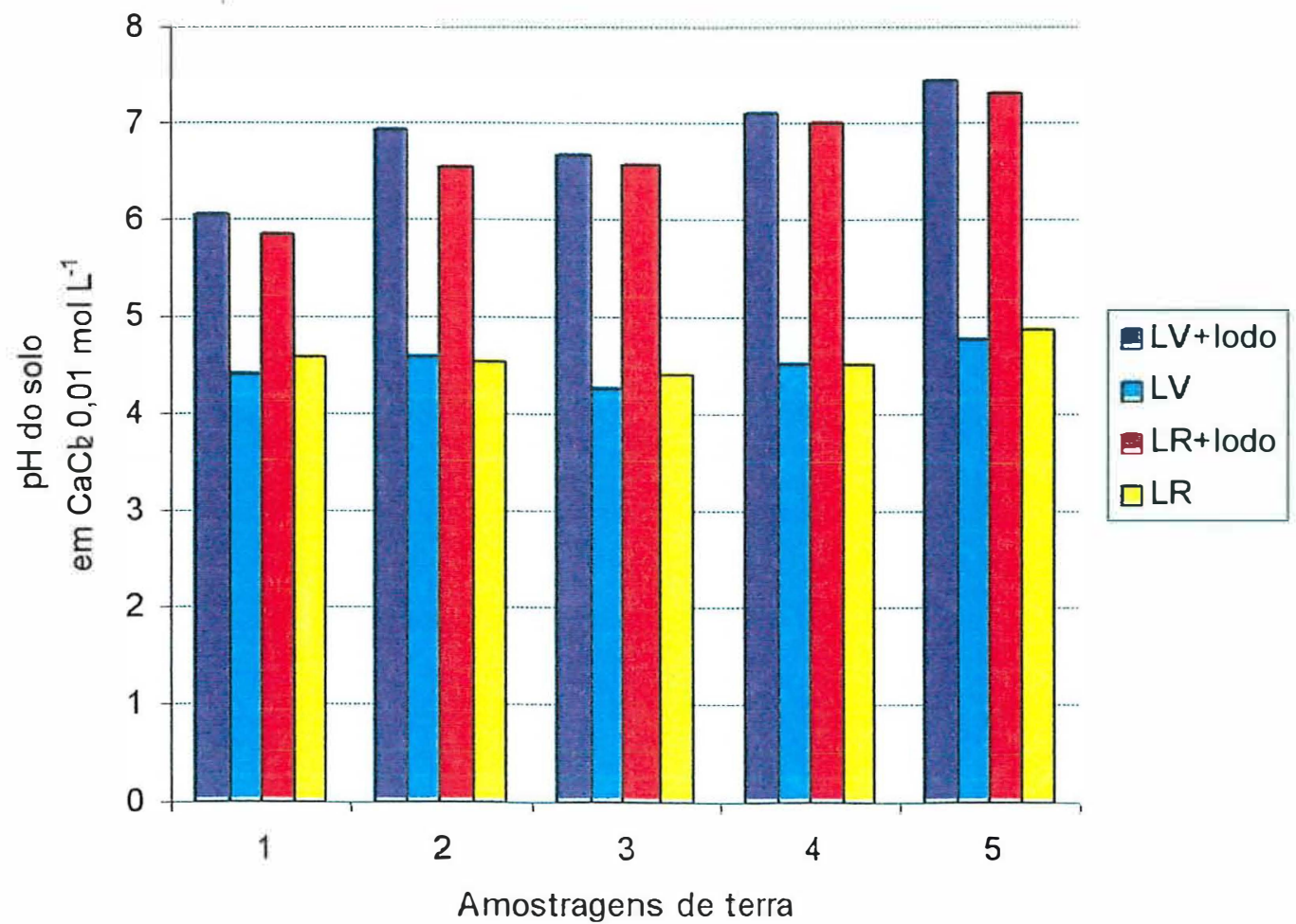

Figura 9 - Variações no pH do solo em função das aplicações de biossólido. 
Dentro de cada tratamento, independente da aplicação de biossólido, foi possível constatar uma diferenciação significativa nos valores médios de $\mathrm{pH}$ da água lixiviada, que variou em torno de 7,4-7,8 nos tratamentos com biossólido e de 7,5-8,4 nos tratamentos testemunhas (Figura 10). Essas diferenças, entretanto só têm expressão pela precisão do experimento e pelo rigor da estatística, pois no campo nada representam. Ao estudar a lixiviação de metais pesados em solos tratados com biossólido, Bertoncini (1997) também observou que o pH dos lixiviados coletados pela passagem de água variou na faixa de 7,1-7,4.

(a)

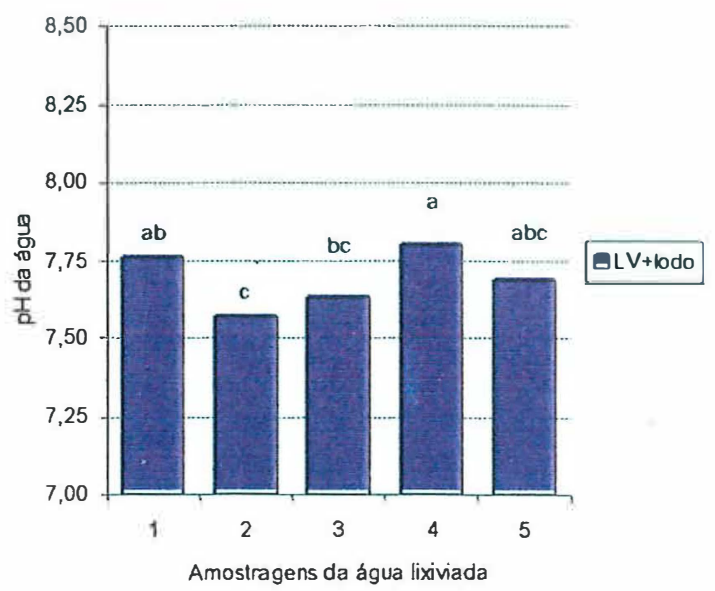

(c)

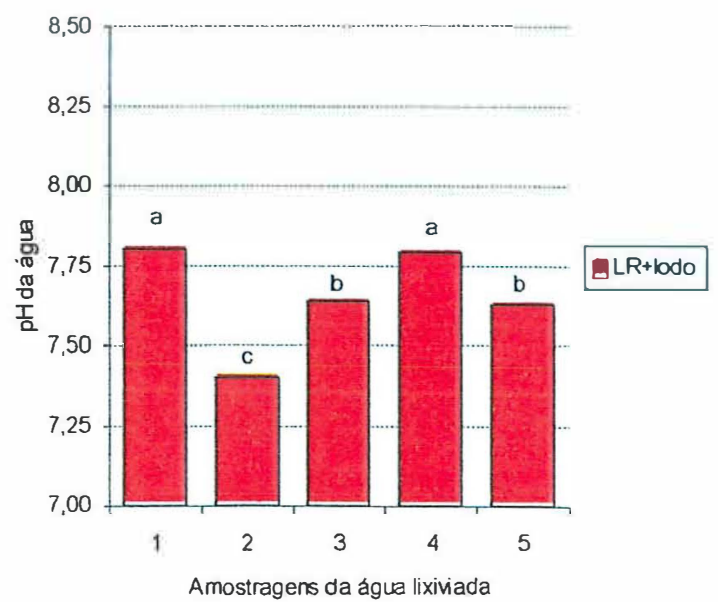

(b)

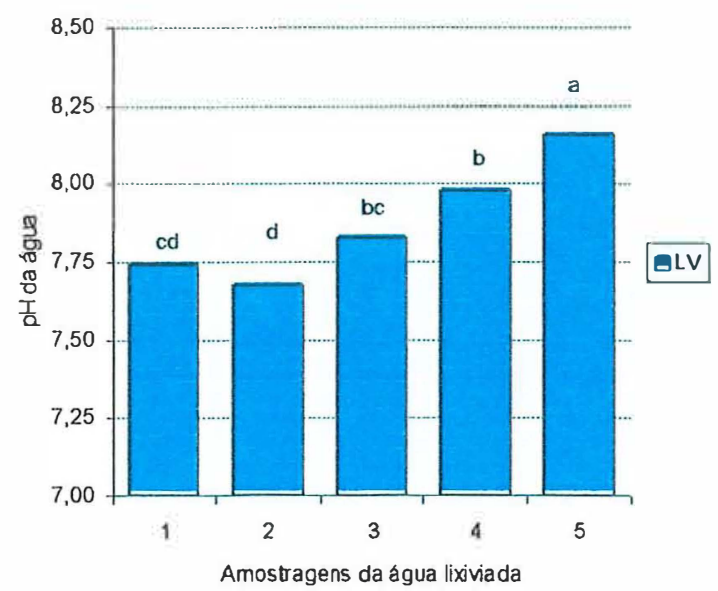

(d)

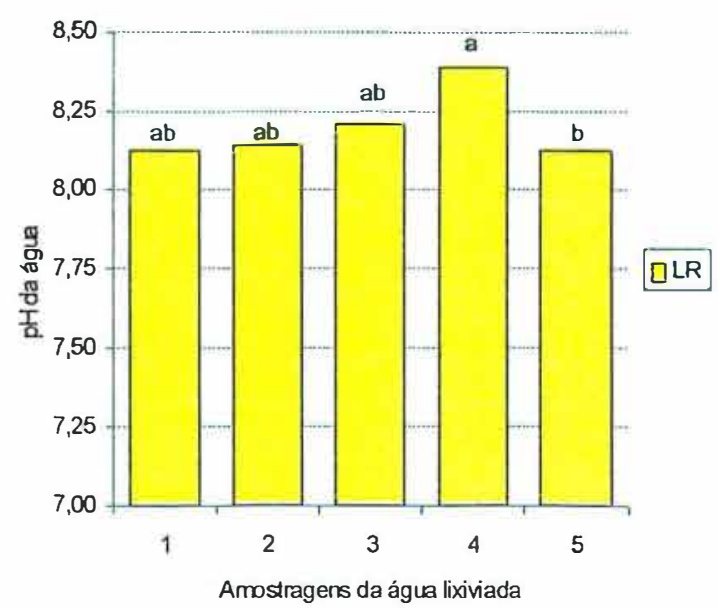

Figura 10 - Variações no pH da água lixiviada em função das aplicações de biossólido dentro de cada tratamento. 
A elevação gradativa do $\mathrm{pH}$ do solo devido as aplicações de biossólido também foi observada por outros autores, dentre eles: Barretto (1995), Oliveira (1995), Bertoncini (1997); Reis (1998) e Pires (1998).

No presente estudo, esse comportamento pode ser explicado pela alcalinidade do resíduo orgânico. Por questões de sanidade e estabilização, o biossólido em estudo recebe $\mathrm{CaO}$, fazendo com que este biossólido promova a correção da acidez devido a formação de $\mathrm{Ca}(\mathrm{OH})_{2}$, que é uma base forte. Segundo Reis (1998), a redução da acidez do solo pela adição de materiais orgânicos, como os biossólidos, que contêm bases inorgânicas é determinada pela ação dessas espécies químicas, independente da natureza e das transformações da fração orgânica destes materiais.

\subsubsection{Condutividade elétrica}

Para as variáveis condutividade elétrica da água e do solo o teste $\mathrm{F}$ detectou diferenças, ao nível de $1 \%$ de significância, na interação dos fatores tratamentos e aplicações de biossólido (Apêndice 1.1 e 3.1, respectivamente).

Comparando-se a condutividade elétrica da água lixiviada dos tratamentos com e sem biossólido (Apêndice 1.2 e Figura 11a), observou-se que desde a primeira até a última aplicação a condutividade elétrica foi significativamente maior nos tratamentos que receberam biossólido. Este comportamento também foi o observado para o solo (Apêndice 3.2 e Figura 11b). Assim, a aplicação de biossólido contribuiu para a elevação da condutividade elétrica da água lixiviada e do solo. 
(a)

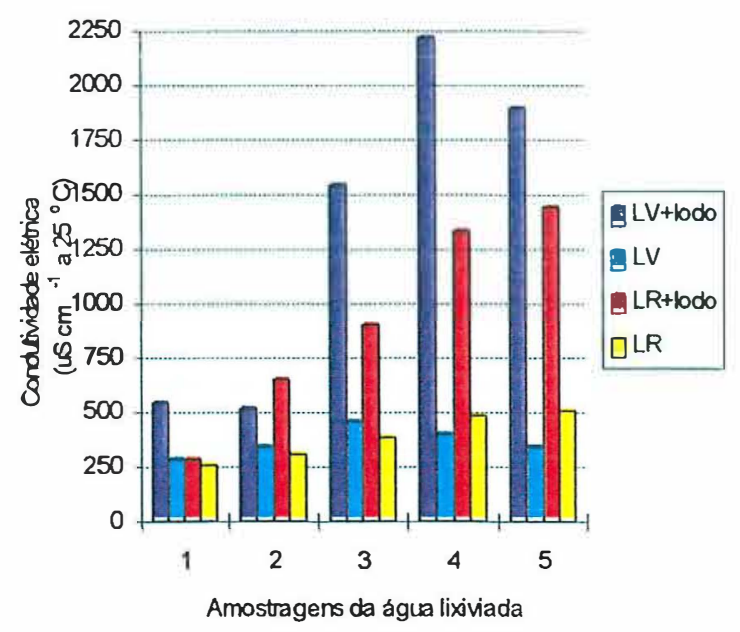

(b)

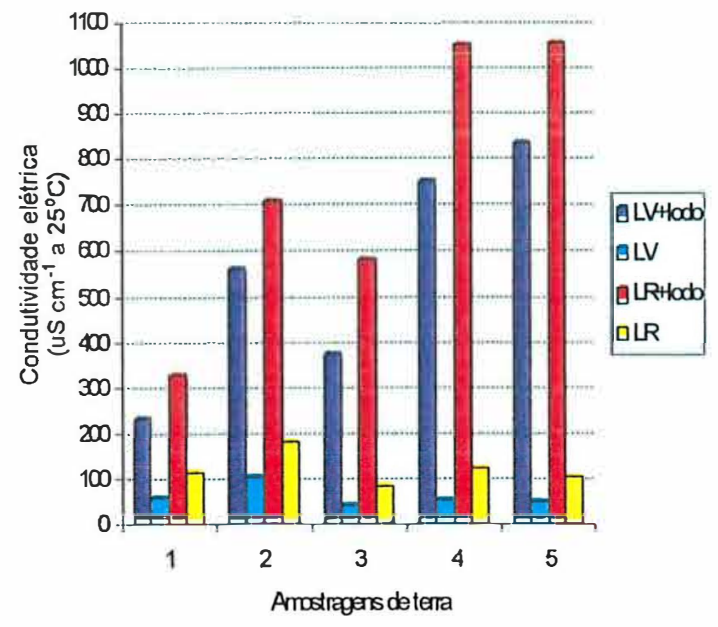

Figura 11 - Variações na condutividade elétrica da água lixiviada (a) e do solo (b) em função das aplicações de biossólido.

Dentro dos tratamentos que receberam biossólido (Apêndice 1.2 e Figura 11a), verificou-se que somente durante o efeito da primeira, terceira e quarta aplicações a condutividade elétrica da água lixiviada foi significativamente maior no LV. Analisando a condutividade elétrica do solo (Apêndice 3.2 e Figura 11 b), constatou-se que desde a primeira até a última aplicação a condutividade elétrica do LR manteve-se significativamente maior do que a do LV. Como o LV apresenta textura média a água ao percolar este solo carrega mais facilmente os íons em solução, fazendo com que a água lixiviada apresente uma condutividade elétrica maior e o solo, uma condutividade elétrica menor.

Ao se estudar a condutividade elétrica da água lixiviada e do solo ao longo das aplicações de biossólido e dentro de cada tratamento (Figuras 12a e 12c referentes a água e Figuras 13a e 13c, ao solo), verificou-se que, nos tratamentos que receberam biossólido, as maiores condutividades elétricas ocorreram durante o efeito da quarta e quinta aplicação de biossólido, períodos de maiores acúmulo de sais proveniente do resíduo e de menores precipitações. 
(a)

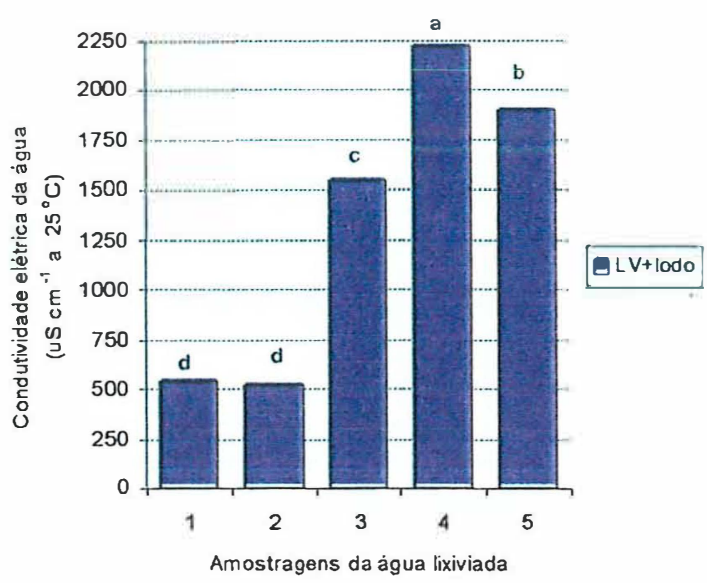

(c)

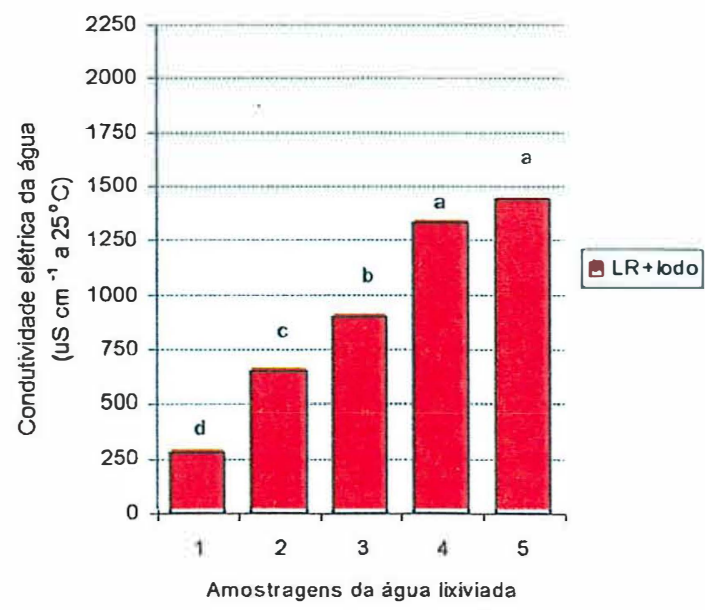

(b)

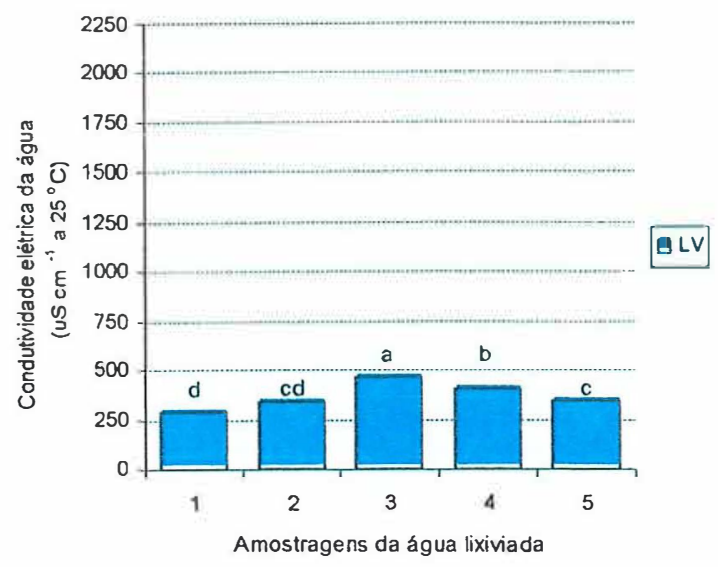

(d)

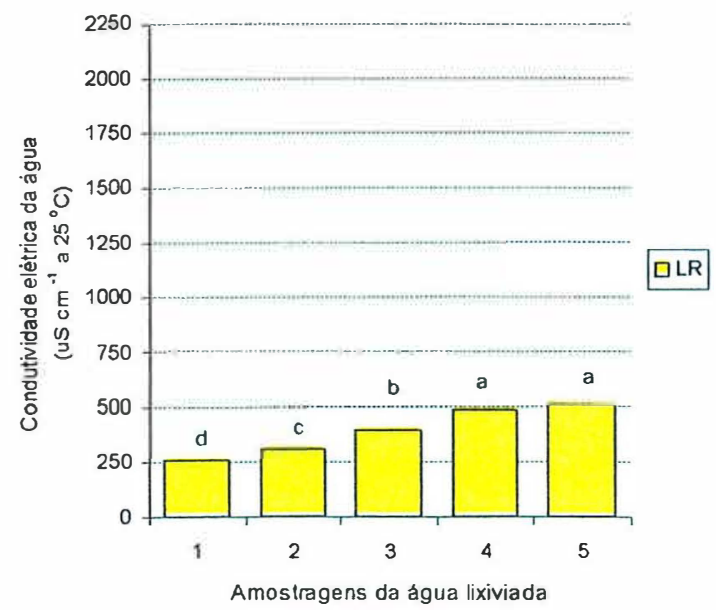

Figura 12 - Variações na condutividade elétrica da água lixiviada em função das aplicações de biossólido dentro de cada tratamento.

Nos tratamentos testemunha (Apêndice 1.2 e Figura 11a), observou-se que apenas na quinta amostragem de água lixiviada foi possível constatar um aumento significativo da condutividade elétrica da água lixiviada no LR. Quanto a condutividade elétrica do solo (Apêndice 3.2 e Figura 11b), esta foi maior no LR desde a primeira amostragem de terra. 
(a)

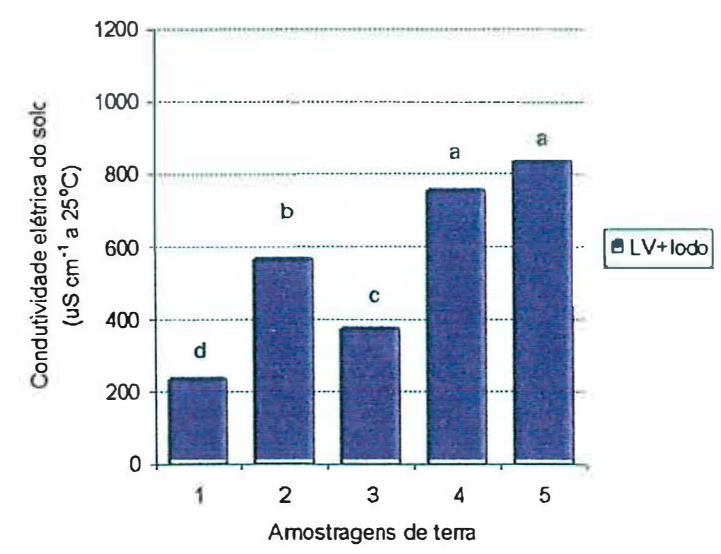

(c)

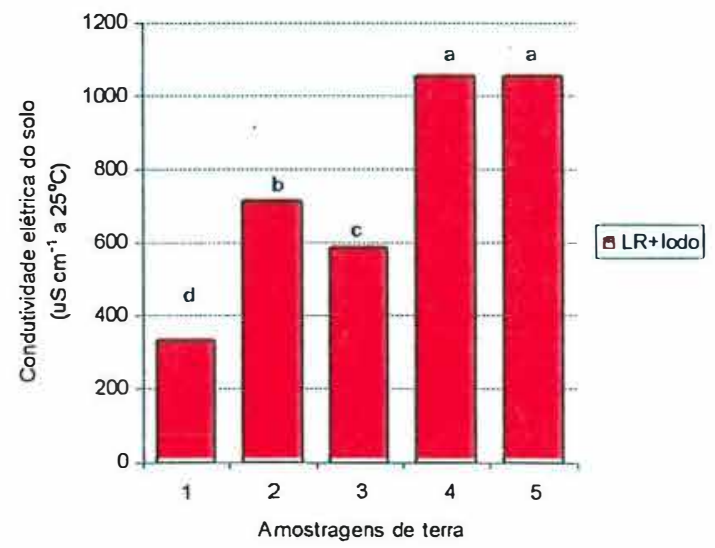

(b)

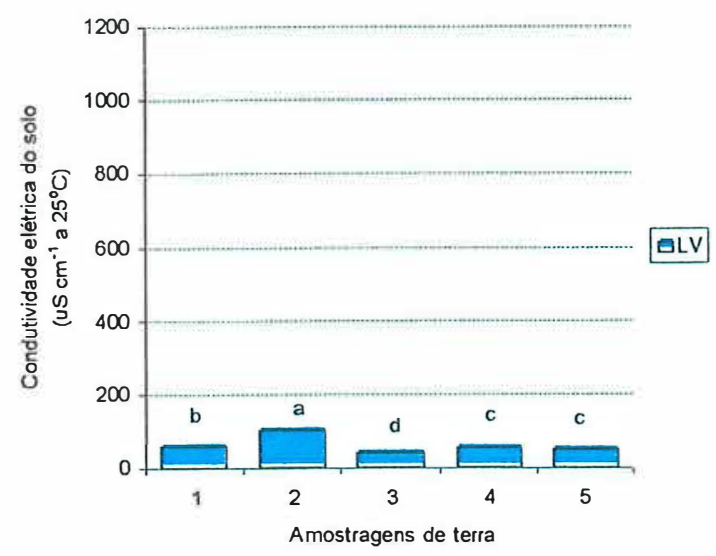

(d)

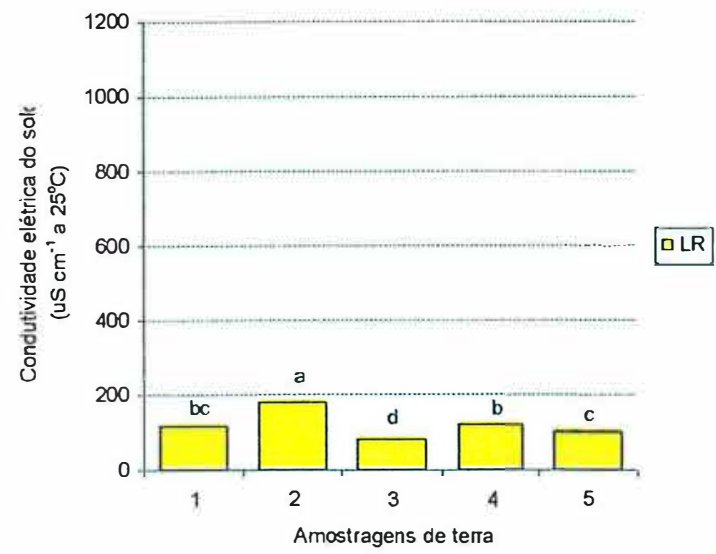

Figura 13 - Variações na condutividade elétrica do solo em função das aplicações de biossólido dentro de cada tratamento.

No decorrer das aplicações do resíduo, a condutividade elétrica da água lixiviada e do solo dos tratamentos testemunhas (Figuras $12 \mathrm{~b}$ e 12d, referentes à água e Figuras $13 \mathrm{~b}$ e $13 \mathrm{~d}$, ao solo) também apresentaram oscilação significativa. No tratamento $\mathrm{LV}$, a condutividade elétrica (Figura 12b) foi maior na terceira amostragem de água, período de maior quantidade de água lixiviada, enquanto que a condutividade elétrica do solo (Figura 13b) foi menor. Quanto ao tratamento LR, a condutividade elétrica (Figura 12d) foi maior na quarta e quinta amostragens de água, períodos de menor precipitação, 
provavelmente devido a fertilidade inicial do LR ser maior do que a do LV (Tabela 4). Quanto a condutividade elétrica do solo (Figura 13d), esta também manteve-se menor na terceira amostragem. Esse comportamento provavelmente está relacionado a fertilidade dos solos, naturalmente o LR apresenta maiores teores de $\mathrm{Ca}^{2+}, \mathrm{Mg}^{2+} \mathrm{e} \mathrm{K}^{+}$(Tabela 4).

Como no presente trabalho, Bertoncini (1997) também constatou a elevação da condutividade elétrica da água que lixivou através de diferentes solos ( $A Q, L V$ e LE) que receberam no total $156 \mathrm{Mg} \mathrm{ha}^{-1}$ de biossólido (base seca). Após incubar por 45 dias o solo com quantidades de biossólido na proporção de 5:1, 7:1, 1:1 e 4:1, Pires (1998), também, observou um aumento da condutividade elétrica do solo em todos esses tratamentos em relação a testemunha.

De modo geral, a condutividade elétrica da água foi positivamente correlacionada com os teores de $\mathrm{Ca}^{2+}, \mathrm{K}^{+}$e $\mathrm{Mg}^{2+}$ presentes na água, enquanto que a condutividade elétrica do solo com os teores de $\mathrm{Ca}^{2+}$ presente no solo (Tabela 21). Contudo, ao se considerar somente os tratamentos com biossólido (Tabela 22), verificou-se que no tratamento $\mathrm{LV}+$ lodo a condutividade elétrica da água não se correlacionou com o teor de $\mathrm{Mg}^{2+}$ na água e que a condutividade elétrica do solo se correlacionou positivamente com os teores de $\mathrm{Ca}^{2+} \mathrm{e} \mathrm{Mg}^{2+}$ do solo. Com relação a condutividade elétrica do percolado, obtido pela passagem de água destilada através do solo, Rodella (1996), após incubar o solo por 30 dias com misturas de turfa e fertilizantes minerais (NPK), verificou que a condutividade elétrica se elevou do primeiro até o terceiro lixiviado. $\mathrm{O}$ autor relacionou essa elevação diretamente com as concentrações de $\mathrm{N}$ total, $\mathrm{K}^{+}$, e principalmente, de

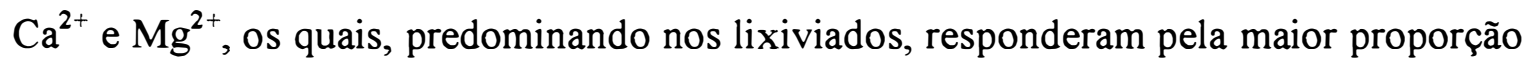
da condutividade elétrica observada. 
Tabela 21. Coeficientes de correlação e respectivas significâncias estatísticas, pelo teste $\mathrm{t}$, entre as variáveis condutividade elétrica, $\mathrm{pH}, \mathrm{K}^{+}, \mathrm{Ca}^{2+}, \mathrm{Mg}^{2+}$ encontradas no solo e na água lixiviada, levando em consideração todos os tratamentos.

\begin{tabular}{|c|c|c|c|c|c|c|c|c|c|}
\hline Variáveis & Cond-sol & Cond-ag & pH-sol & $\mathrm{pH}-\mathrm{ag}$ & K-sol & K-ag & Ca-sol & Ca-ag & Mg-sol \\
\hline Cond-ag & $0,75^{* *}$ & & & & & & & & \\
\hline $\mathrm{pH}-\mathrm{sol}$ & $0,90^{* *}$ & $0,78^{* *}$ & & & & & & & \\
\hline $\mathrm{pH}-\mathrm{ag}$ & $-0,39 * *$ & $-0,25^{*}$ & $-0,42 * *$ & & & & & & \\
\hline K-sol & 0,20 & 0,23 & 0,16 & 0,02 & & & & & \\
\hline K-ag & $0,53 * *$ & $0,73^{* *}$ & $0,62 * *$ & $-0,25 *$ & 0,05 & & & & \\
\hline Ca-sol & $0,89 * *$ & $0,52^{* *}$ & $0,78^{* *}$ & $-0,31 * *$ & $0,37 * *$ & $0,44^{* *}$ & & & \\
\hline Ca-ag & $0,61^{* *}$ & $0,88^{* *}$ & $0,71^{* *}$ & $-0,27^{*}$ & 0,03 & $0,88^{* *}$ & $0,43 * *$ & & \\
\hline Mg-sol & 0,13 & $-0,15$ & $-0,07$ & $0,32 * *$ & $0,42 * *$ & $-0,12$ & $0,43 * *$ & $-0,19$ & \\
\hline Mg-ag & $0,50^{* *}$ & $0,68^{* *}$ & $0,60 * *$ & $-0,30 * *$ & 0,06 & $0,95^{* *}$ & $0,43 * *$ & $0,90 * *$ & $-0,16$ \\
\hline
\end{tabular}

No presente trabalho a condutividade elétrica do solo dos tratamentos que receberam biossólido se manteve abaixo de $2.000 \mu \mathrm{S} \mathrm{cm}^{-1}$, condição esta para que o solo seja classificado como não salino (Jones Jr., 1983), entretanto convém ressaltar que essa condutividade foi obtida em suspensão solo/água na proporção 1:1, enquanto que Jones $\mathrm{Jr}$, em extrato de saturação de solo. Caso tivesse sido realizada em extrato de saturação, essa condutividade elétrica atingiria valores próximos ou até maiores que $2.000 \mu \mathrm{S} \mathrm{cm}^{-1}$. Dessa forma, dependendo da dose aplicada ou das sucessivas aplicações de biossólido na mesma área juntamente com as condições pluviométricas regionais poderá haver períodos de maior perigo de salinização tanto da água lixiviada como do próprio solo. No caso de salinização do solo poderá haver inclusive prejuizo ao desenvolvimento das plantas. Cripps \& Matocha (1991) ressaltam que um dos problemas da utilização de biossólido em áreas agrícolas é a salinização que este pode provocar no solo. 
Tabela 22. Coeficientes de correlação e respectivas significâncias estatísticas, pelo teste $\mathrm{t}$, entre as variáveis condutividade elétrica, $\mathrm{pH}, \mathrm{K}^{+}, \mathrm{Ca}^{2+}, \mathrm{Mg}^{2+}$ encontradas no solo e na água lixiviada, referentes ao tratamento LV+lodo e LR+lodo.

\begin{tabular}{|c|c|c|c|c|c|c|c|c|c|}
\hline Variáveis & Cond-sol & Cond-ag & pH-sol & $\mathrm{pH}-\mathrm{ag}$ & K-sol & K-ag & Ca-sol & Ca-ag & Mg-sol \\
\hline & \multicolumn{9}{|c|}{ LV+lodo } \\
\hline Cond-ag & $0,66^{* *}$ & & & & & & & & \\
\hline pH-sol & $0,91^{* *}$ & $0,70^{* *}$ & & & & & & & \\
\hline $\mathrm{pH}-\mathrm{ag}$ & 0,02 & 0,28 & $-0,01$ & & & & & & \\
\hline K-sol & $0,52 *$ & $0,76^{* *}$ & $0,62 * *$ & 0,06 & & & & & \\
\hline $\mathrm{K}-\mathrm{ag}$ & 0,14 & $0,52^{*}$ & 0,33 & $-0,02$ & $0,66^{* *}$ & & & & \\
\hline $\mathrm{Ca}$-sol & $0,90 * *$ & $0,86 * *$ & $0,92 * *$ & 0,07 & $0,70^{* *}$ & 0,39 & & & \\
\hline Ca-ag & $0,44^{*}$ & $0,79 * *$ & $0,57 * *$ & $-0,04$ & $0,84^{* *}$ & $0,81^{* *}$ & $0,71^{* *}$ & & \\
\hline Mg-sol & $0,69 * *$ & $0,60^{* *}$ & $0,54^{*}$ & 0,42 & 0,34 & $-0,03$ & $0,68 * *$ & 0,32 & \\
\hline \multirow[t]{2}{*}{ Mg-ag } & 0,06 & 0,44 & 0,24 & $-0,13$ & $0,69 * *$ & $0,94 * *$ & 0,33 & $0,86 * *$ & $-0,08$ \\
\hline & \multicolumn{9}{|c|}{ LR+lodo } \\
\hline Cond-ag & $0,91^{* *}$ & & & & & & & & \\
\hline pH-sol & $0,90 * *$ & $0,90 * *$ & & & & & & & \\
\hline $\mathrm{pH}-\mathrm{ag}$ & $-0,10$ & 0,09 & $-0,09$ & & & & & & \\
\hline K-sol & $-0,25$ & $-0,22$ & $-0,25$ & 0,28 & & & & & \\
\hline K-ag & $0,50^{*}$ & $0,74 * *$ & $0,70^{* *}$ & 0,01 & $-0,16$ & & & & \\
\hline Ca-sol & $0,87^{* *}$ & $0,90^{* *}$ & $0,83 * *$ & 0,14 & $-0,12$ & $0,57 * *$ & & & \\
\hline $\mathrm{Ca}-\mathrm{ag}$ & $0,60 * *$ & $0,78^{* *}$ & $0,77 * *$ & $-0,11$ & $-0,22$ & $0,96^{* *}$ & $0,62^{* *}$ & & \\
\hline Mg-sol & 0,14 & 0,20 & 0,08 & 0,37 & 0,32 & 0,19 & $0,49^{*}$ & 0,14 & \\
\hline Mg-ag & $0,50^{*}$ & $0,71^{* *}$ & $0,68 * *$ & $-0,15$ & $-0,23$ & $0,93 * *$ & $0,53^{*}$ & $0,98^{* *}$ & 0,05 \\
\hline
\end{tabular}

ag. = Água lixiviada.

sol. $=$ Solo.

Cond. $=$ Condutividade elétrica .

$*$ = Significativo ao nivel de $5 \%(\alpha \leq 0,05)$.

** = Significativo ao nível de $1 \%(\alpha \leq 0,01)$.

\subsubsection{Lixiviação de $\mathrm{K}^{+}, \mathrm{Ca}^{2+}$ e $\mathrm{Mg}^{2+}$}

Para as variáveis quantidades lixiviadas de $\mathrm{K}^{+}, \mathrm{Ca}^{2+}$ e $\mathrm{Mg}^{2+}$ e teores de $\mathrm{Ca}^{2+}$ e $\mathrm{Mg}^{2+}$ no solo, o teste $\mathrm{F}$ detectou diferenças, ao nível de $1 \%$ de significância, na interação 
dos fatores tratamentos e aplicações de biossólido (Apêndice 1.1 e 3.1, respectivamente relacionados as variáveis da água e do solo).

Quanto a variável teores de $\mathrm{K}^{+}$no solo, esta foi influenciada somente pelos tratamentos, sendo comprovado estatisticamente pela significância do teste $\mathrm{F}$ ao nível de 1\% (Apêndice 3.1)

Ao se comparar tratamentos com biossólido e tratamentos testemunhas, verificou-se que a adição de biossólido contribuiu para a elevação dos teores de $\mathrm{K}^{+}$e $\mathrm{Ca}^{2+}$ no solo (Apêndice 3.2 e Figuras 14b e 15b). Quanto a lixiviação destes elementos, observou-se que a partir da segunda aplicação do resíduo houve maior lixiviação de $\mathrm{Ca}^{2+}$ (Apêndice 1.2 e Figuras 15a) e a partir da terceira aplicação foi possível constatar também a maior lixiviação de $\mathrm{K}^{+}$(Apêndice 1.2 e Figura 14a) nesses tratamentos.

Tanto dentro dos tratamentos com quanto sem biossólido constatou-se que os maiores teores de $\mathrm{K}^{+}$e $\mathrm{Ca}^{2+}$ foram encontrados na amostra de terra LR (Apêndice $3.2 \mathrm{e}$ Figuras $14 \mathrm{~b}$ e $15 \mathrm{~b})$.

(a)

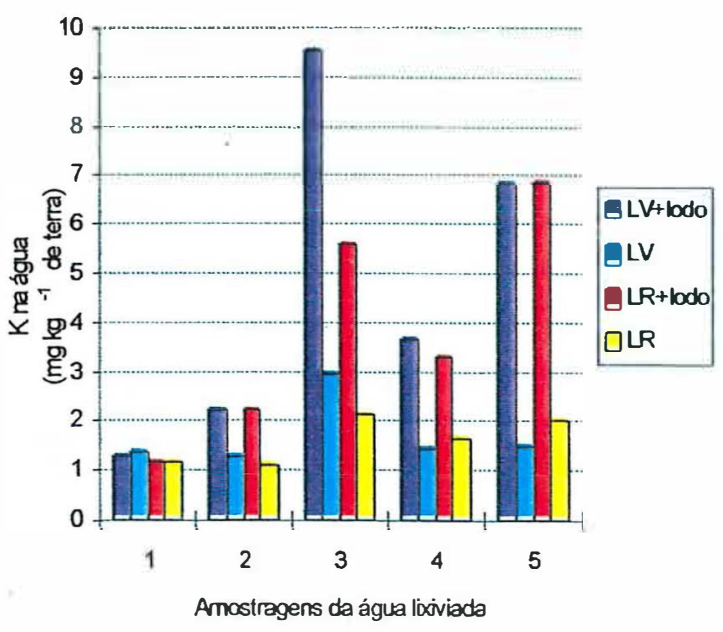

(b)

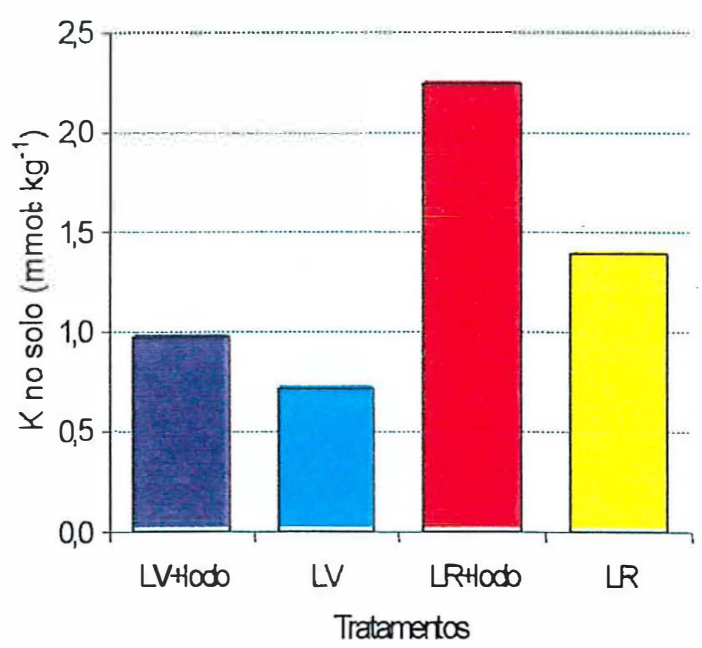

Figura 14 - Variações na quantidade de $\mathrm{K}^{+}$no lixiviado (a) e no teor de $\mathrm{K}^{+}$no solo (b) em função das aplicações de biossólido. 
Com relação aos teores de $\mathrm{Mg}^{2+}$ no solo, não se observou, em nenhuma das aplicações, que os teores deste elemento nos tratamentos com biossólido diferissem significativamente dos teores da testemunha (Apêndice 3.2 e Figura 16b), o que demonstra que apesar de ter sido adicionado $112 \mathrm{~g}$ de $\mathrm{Mg}^{2+}$ nas caixas $\left(1.173 \mathrm{~kg} \mathrm{ha}^{-1}\right.$ ) não foi suficiente para elevar o teor trocável do elemento. Todavia, a lixiviação de $\mathrm{Mg}^{2+}$ foi observada a partir da segunda aplicação de biossólido (Apêndice 1.2 e Figura 16a).

(a)

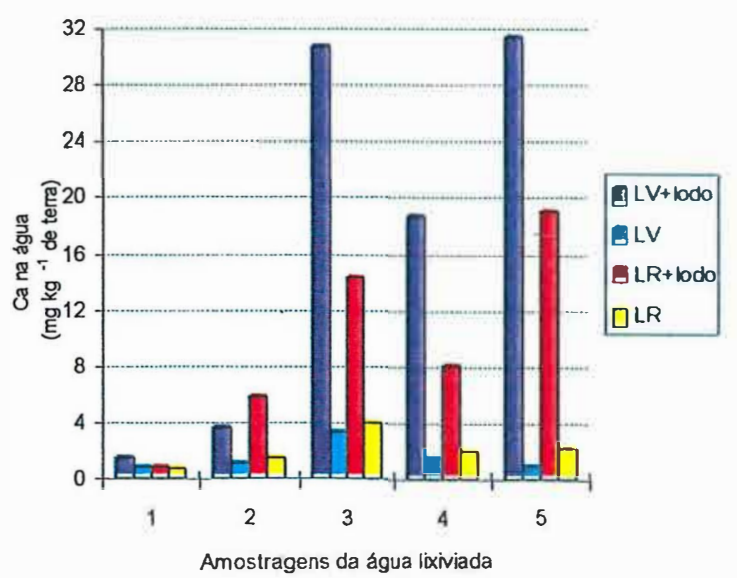

(b)

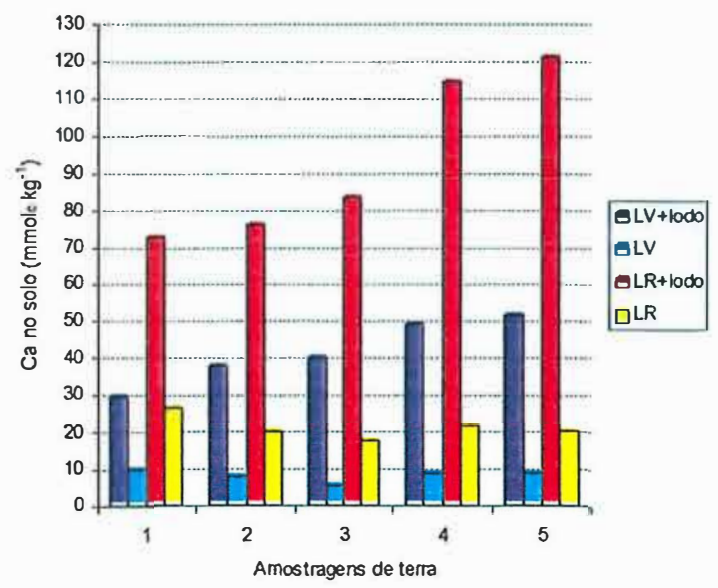

Figura 15 - Variações na quantidade de $\mathrm{Ca}^{2+}$ no lixiviado (a) e no teor de $\mathrm{Ca}^{2+}$ no solo (b) em função das aplicações de biossólido.

Dentro dos tratamentos com biossólido verificou-se que, desde a primeira até a última aplicação, os maiores teores $\mathrm{Mg}^{2+}$ foram encontrados nas amostras coletadas do LR e que dentro dos tratamentos que não receberam biossólido, somente na primeira amostragem, verificou-se maiores teores de $\mathrm{Mg}^{2+}$ nas amostras de terra LR (Apêndice 3.2 e Figura 16b).

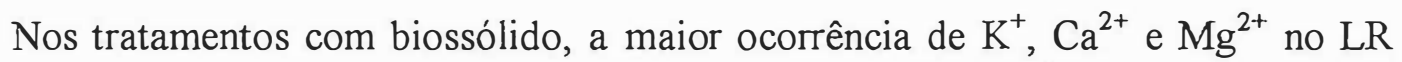
pode estar relacionada ao maior ocorrência natural destes elementos nesse tipo de solo (Tabela 4) e também aos maiores valores de CTC, teor de argila e teores de óxidos de Fe e $\mathrm{Al}$ (Tabelas 4 e 5), características estas que conferem maior retenção desses cátions 
quando oriundos da adição do resíduo, enquanto que nos tratamentos testemunha, devase simplesmente ao fato do LR apresentar maior fertilidade natural que o LV.

Confrontando-se os tratamentos que receberam biossólido, constatou-se que a partir da terceira aplicação começou a ocorrer uma maior lixiviação de $\mathrm{Ca}^{2+}$ nas amostras de terra LV (Apêndice 1.2 e Figura 15a), enquanto apenas na terceira aplicação verificou-se uma maior lixiviação de $\mathrm{Mg}^{2+}$ nesta mesma amostra de terra (Apêndice 1.2 e Figura 16a).

(a)

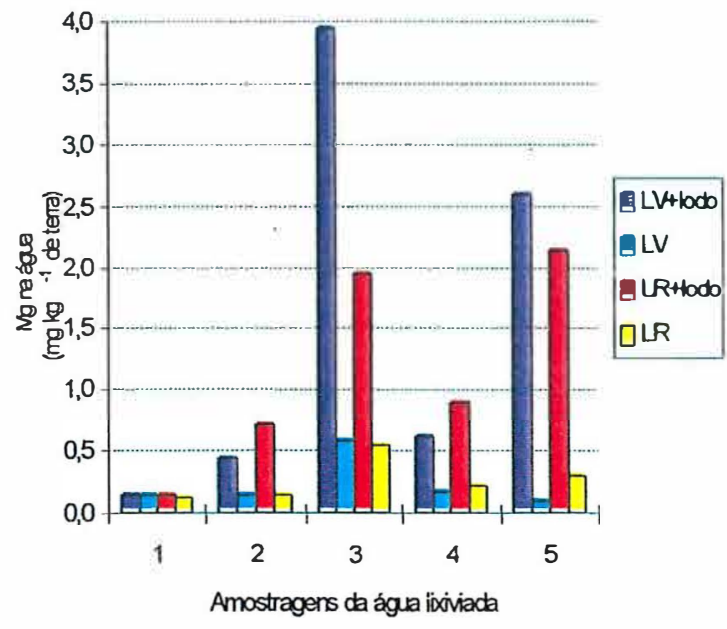

(b)

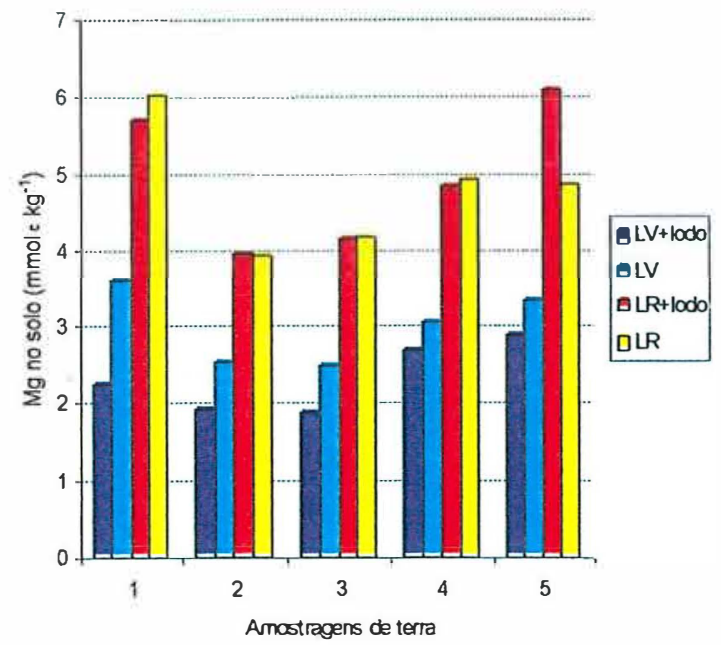

Figura 16 - Variações na quantidade de $\mathrm{Mg}^{2+}$ no lixiviado (a) e no teor de $\mathrm{Mg}^{2+}$ no solo (b) em função das aplicações de biossólido.

$\mathrm{O}$ comportamento do $\mathrm{Ca}^{2+}$ pode estar relacionado a maior percolação de água verificada durante o efeito da terceira aplicação de biossólido e também ao fato do acúmulo de $\mathrm{Ca}^{2+}$ no solo, via sucessivas adições de biossólido, ter ultrapassado mais rapidamente a capacidade de retenção do LV do que a do LR. Naturalmente o LV apresenta menores CTC, teor de óxidos e argila (Tabelas 4 e 5), características estas que confeririam menor retenção de cátions.

Quanto ao comportamento do $\mathrm{Mg}^{2+}$, este provavelmente deva-se somente a maior 
drenagem de água ocorrida durante o efeito da terceira aplicação de biossólido, uma vez que as quantidades adicionadas deste elemento ao solo, via biossólido, foram bem inferiores às quantidades adicionadas de $\mathrm{Ca}^{2+}$ (Tabela 8).

$\mathrm{Na}$ Tabela 23, também, constata-se que a amostra de terra LV foi a que mais favoreceu a lixiviação das espécies químicas estudadas. Pela análise dos teores de $\mathrm{K}^{+}$, $\mathrm{Ca}^{2+} \mathrm{e} \mathrm{Mg}^{2+}$ (Figuras 14b, 15b e 16b, respectivamente) nota-se a ocorrência de menores teores destes cátions nas amostras de terra LV.

Embora grandes quantidades de $\mathrm{Ca}^{2+}$ e $\mathrm{Mg}^{2+}$ tenham sido lixiviadas dos tratamentos com biossólido a partir da segunda aplicação e de $\mathrm{K}^{+}$a partir da terceira aplicação, verificou-se que as percentagens de lixiviação destas espécies químicas em relação as quantidades totais presentes nas amostras de terra foram pequenas (Tabela 23).

Considerando a quantidade total de $\mathrm{K}^{+}, \mathrm{Ca}^{2+} \mathrm{e}^{2+}$ perdidos por lixiviação e a quantidade adicionada destes elementos via biossólido, verifica-se que ao final do período de monitoramento $16 \%$ e $10 \%$ do $\mathrm{K}^{+}$aplicado foi perdido, respectivamente, por lixiviação no $L V$ e LR. Para o $\mathrm{Ca}^{2+}$, essa perda foi cerca de $1 \%$ no $L V$ e no $L R$ não foi observada lixiviação por efeito do biossólido, enquanto que para o $\mathrm{Mg}^{2+}$ estes valores foram de $3 \%$ para o $L V$ e $2 \%$ para o $L R$.

Desta forma, a ordem de lixiviação nos tratamentos $\mathrm{LV}+$ lodo e $\mathrm{LR}+$ lodo foi $\mathrm{K}^{+}>$ $\mathrm{Mg}^{2+}>\mathrm{Ca}^{2+}$.

Durante o efeito da terceira aplicação de biossólido, período de maior percolação de água nas caixas, manteve-se a mesma ordem de lixiviação, com a porcentagem de lixiviação de $\mathrm{K}^{+}, \mathrm{Mg}^{2+}$ e $\mathrm{Ca}^{2+}$ no tratamento $\mathrm{LV}+$ lodo sendo da ordem de, respectivamente, $18 \%, 7 \%$ e $1 \%$ da quantidade total presente no solo (Tabela 23 ). Esse comportamento foi contrário ao observado por Riekerk (1978), que ao aplicar 247 $\mathrm{Mg} \mathrm{ha}{ }^{-1}$ de biossólido, base seca, em solo florestal cascalhento verificou que as primeiras perdas anuais devido ao tratamento foram de $15 \%$ do $\mathrm{Ca}$ adicionado e $1 \%$ do $\mathrm{K}$. 
Tabela 23. Quantidade de $\mathrm{K}^{+}, \mathrm{Ca}^{2+}{\mathrm{e} \mathrm{Mg}^{2+} \text { lixiviada (mg volume total lixiviado }}^{-1}$ ) nos

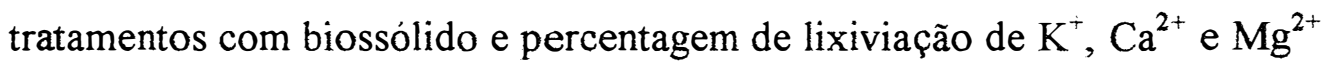
em função da quantidade total destes elementos presentes nas amostras de terra.

\begin{tabular}{|c|c|c|c|c|c|c|}
\hline \multirow[t]{3}{*}{ Tratamentos } & $1^{\mathrm{a}}$ aplicação & $2^{2}$ aplicação & $3^{\AA}$ aplicação & $4^{\natural}$ aplicação & $5^{\underline{a}}$ aplicação & Total \\
\hline & \multirow{2}{*}{\multicolumn{6}{|c|}{$\begin{array}{c}\mathrm{K}^{+} \\
-\end{array}$}} \\
\hline & & & & & & \\
\hline LV+lodo & 711 & 1.224 & 5.293 & 2.035 & 3.802 & 13.065 \\
\hline LV & 746 & 710 & 1.628 & 786 & 819 & 4.689 \\
\hline LR+lodo & 556 & 1.083 & 2.717 & 1.608 & 3.334 & 9.298 \\
\hline \multirow[t]{2}{*}{ LR } & 572 & 518 & 1.033 & 790 & 986 & 3.899 \\
\hline & \multicolumn{6}{|c|}{$\mathrm{Ca}^{2+}$} \\
\hline LV+lodo & 862 & 2.023 & 17.094 & 10.400 & 17.437 & 47.816 \\
\hline LV & 480 & 616 & 1.887 & 797 & 539 & 4.319 \\
\hline LR+lodo & 416 & 2.857 & 6.956 & 3.953 & 9.257 & 23.439 \\
\hline \multirow[t]{2}{*}{ LR } & 368 & 750 & 1.916 & 990 & 1.094 & 5.118 \\
\hline & \multicolumn{6}{|c|}{$\mathrm{Mg}^{2+}$} \\
\hline LV+lodo & 79 & 245 & 2.189 & 337 & 1.444 & 4.294 \\
\hline LV & 79 & 82 & 323 & 100 & 50 & 634 \\
\hline LR+lodo & 71 & 347 & 943 & 439 & 1.039 & 2.839 \\
\hline \multirow[t]{2}{*}{ LR } & 61 & 68 & 269 & 105 & 142 & 645 \\
\hline & \multicolumn{6}{|c|}{$\mathrm{K}^{+}$} \\
\hline LV+lodo & 4,78 & 4,86 & 18,21 & 5,89 & 10,93 & $\mathrm{nc}$ \\
\hline LV & 4,92 & 4,68 & 8,34 & 5,18 & 5,40 & $\mathrm{nc}$ \\
\hline LR+lodo & 1,67 & 2,82 & 6,18 & 3,75 & 7,10 & $\mathrm{nc}$ \\
\hline \multirow[t]{2}{*}{ LR } & 2,01 & 1,82 & 4,19 & 2,78 & 4,00 & $\mathrm{nc}$ \\
\hline & \multicolumn{6}{|c|}{$\mathrm{Ca}^{2+}$} \\
\hline LV+lodo & 0,10 & 0,17 & 1,31 & 0,71 & 1,11 & nc \\
\hline LV & 0,44 & 0,68 & 3,03 & 0,82 & 0,55 & $\mathrm{nc}$ \\
\hline LR+lodo & 0,05 & 0,18 & 0,43 & 0,22 & 0,43 & $\mathrm{nc}$ \\
\hline \multirow[t]{2}{*}{ LR } & 0,14 & 0,38 & 1,11 & 0,46 & 0,54 & $\mathrm{nc}$ \\
\hline & \multicolumn{6}{|c|}{$\mathrm{Mg}^{2+}$} \\
\hline LV+lodo & 0,32 & 0,66 & 6,74 & 1,02 & 3,23 & $\mathrm{nc}$ \\
\hline LV & 0,33 & 0,47 & 1,94 & 0,48 & 0,23 & $\mathrm{nc}$ \\
\hline LR+lodo & 0,23 & 0,63 & 2,19 & 0,98 & 1,90 & $\mathrm{nc}$ \\
\hline LR & 0,17 & 0,30 & 1,10 & 0,37 & 0,50 & $\mathrm{nc}$ \\
\hline
\end{tabular}

nc $=$ não calculado. 
As lixiviações das espécies químicas do presente trabalho são menores que as observadas por Bertoncini (1997), que após incorporar quantidades sucessivas de biossólido, num total correspondente a $156 \mathrm{Mg} \mathrm{ha}^{-1}$, base seca, em três solos colocados em tubos de percolação, constatou que a quantidade de $\mathrm{Ca}^{2+}$ removida pela passagem de água foi de 13, 19 e 18\% do total presente no solo, respectivamente, nos tratamentos $\mathrm{AQ}, \mathrm{LV}$ e LR com biossólido, enquanto que a quantidade de $\mathrm{Mg}^{2+}$ removida foi de 9,20 e $11 \%$ do total presente, respectivamente.

Nas Tabelas 21 e 22 verifica-se que a quantidade de $\mathrm{K}^{\top}$ presente na água lixiviada foi alta e positivamente correlacionada com as quantidades de $\mathrm{Ca}^{2+}{\mathrm{e} \mathrm{Mg}^{2+} \mathrm{na}}^{2}$ água, tanto ao se considerar todos os tratamentos como somente cada tratamento com biossólido, com coeficientes de correlação da ordem de $0,81-0,96^{* *}$ para o $\mathrm{Ca}^{2+}$ e de $0,93-0,95^{* *}$ para o $\mathrm{Mg}^{2+}$. Constata-se também uma correlação moderada e positiva ( $\mathrm{r}=$ $0,62^{* *}$ ) entre a quantidade de $\mathrm{K}^{+}$na água e o $\mathrm{pH}$ do solo, ao se considerar o estudo de todos os tratamentos e uma correlação alta e positiva $\left(r=0,70^{* *}\right)$ ao se considerar o estudo somente no tratamento LR+lodo. Estas observações estão de acordo com Goulding \& Talibudeen (1984) e Chaves \& Libardi (1995), que observaram uma diminuição da seletividade de adsorção do cátion $\mathrm{K}^{+}$em relação ao $\mathrm{Ca}^{2+}$ com aumento do $\mathrm{pH}$ da solução do solo. Os autores relacionaram este comportamento com o aumento da densidade superficial de cargas, que por conseqüência favorece preferencialmente a adsorção dos cátions divalentes. Salazar et al. (1995), ao trabalhar com dois solos distintos, verificaram este comportamento apenas no solo com alto teor de matéria orgânica. Segundo estes autores, os grupos carboxílicos da matéria orgânica do solo se ionizam progressivamente quando $\mathrm{o} \mathrm{pH}$ do solo se eleva, aumentando as cargas negativas, que favorece a adsorção do $\mathrm{Ca}^{2+}$. O estabelecimento de ligações mais fortes entre $\mathrm{Ca}^{2+}$ e matéria orgânica foi relatado também por Bladel \& Gheyi (1980).

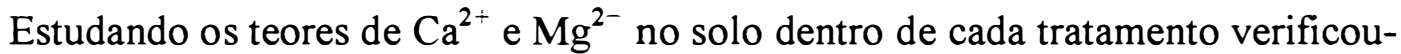
se que no tratamento LV+lodo (Figuras $17 \mathrm{a}$ e 18a, respectivamente), os maiores teores

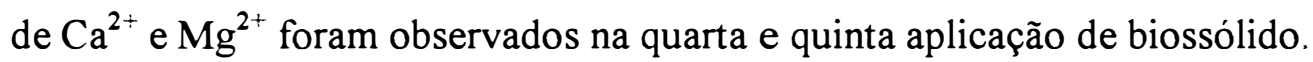


(a)

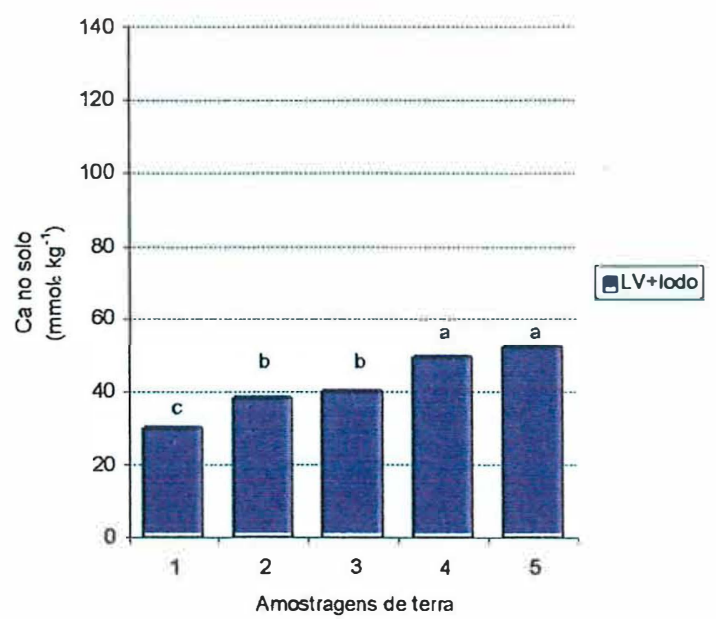

(c)

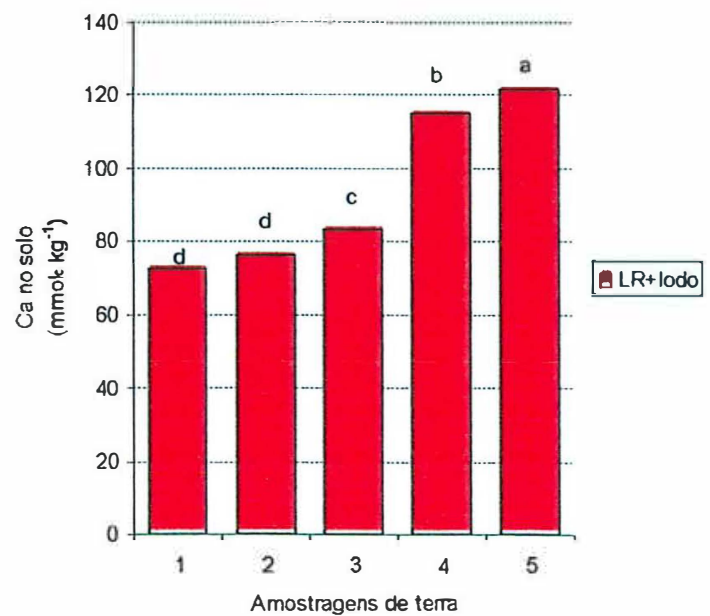

(b)

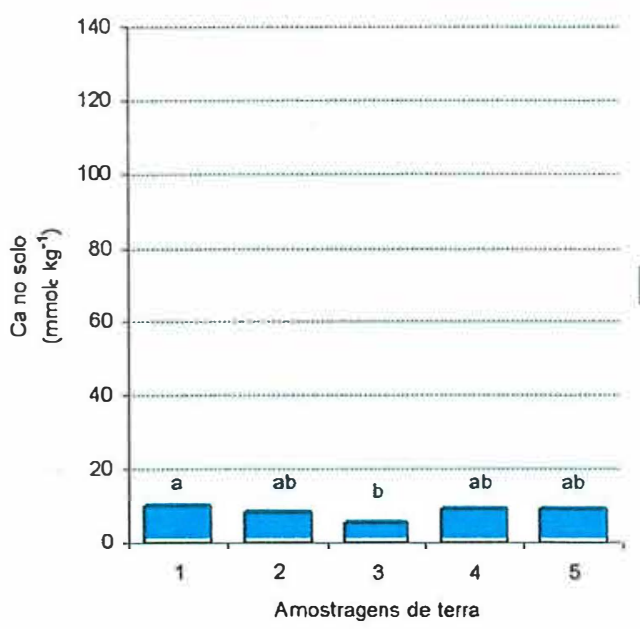

(d)

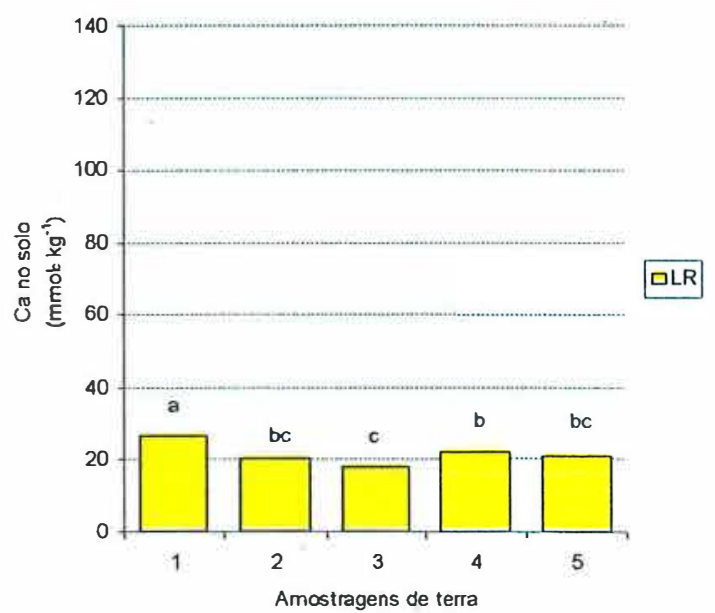

Figura 17 - Variações no teor de $\mathrm{Ca}^{2+}$ no solo em função das aplicações de biossólido dentro de cada tratamento.

Já no tratamento $\mathrm{LR}+$ lodo, os maiores teores de $\mathrm{Ca}^{2+}$ encontrados nas amostras de terra ocorreram durante o efeito da quinta aplicação (Figura 17c), enquanto que os maiores teores de $\mathrm{Mg}^{2+}$, durante o efeito da primeira e da última aplicação de biossólido (Figura 18c). 
(a)

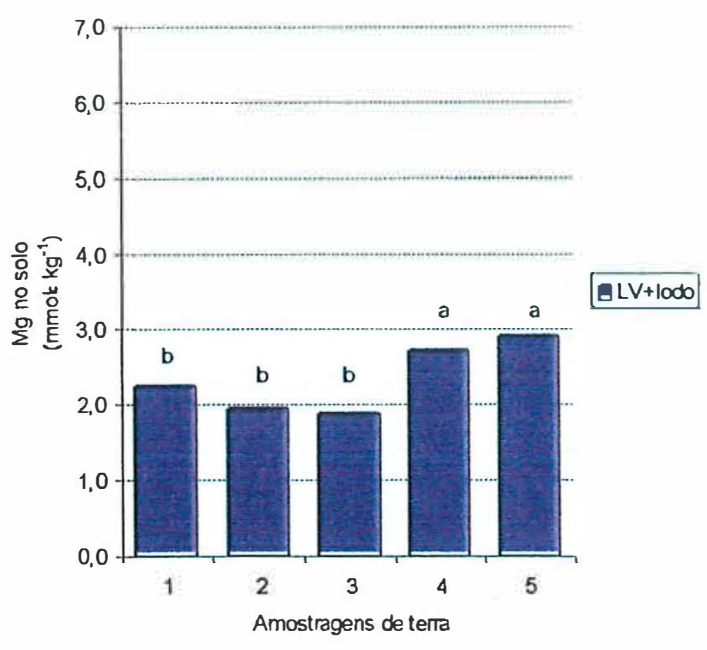

(c)

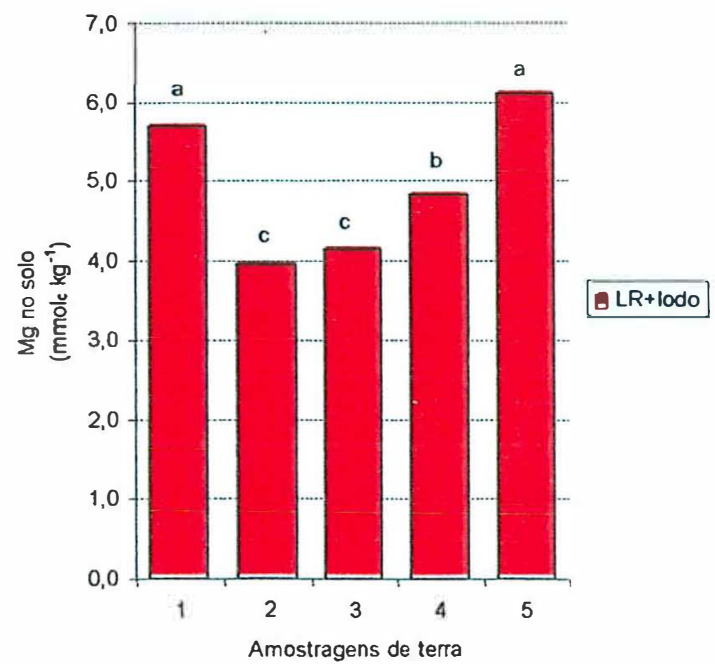

(b)

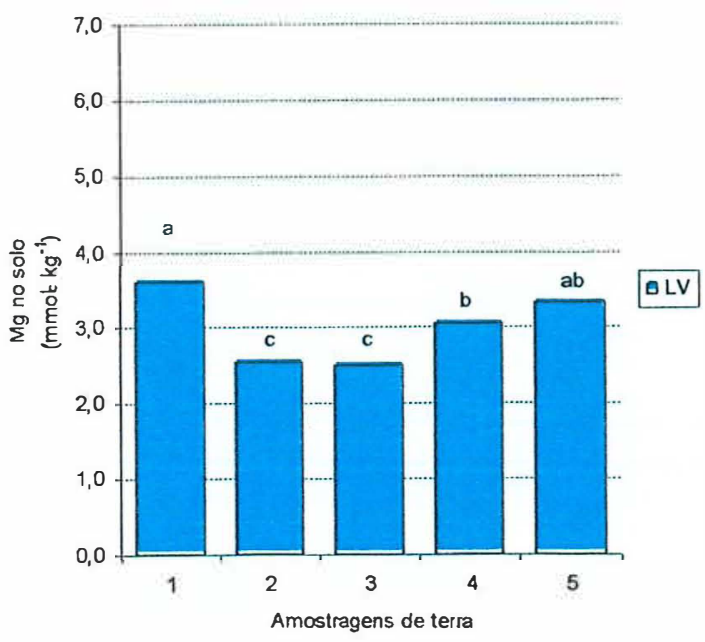

(d)

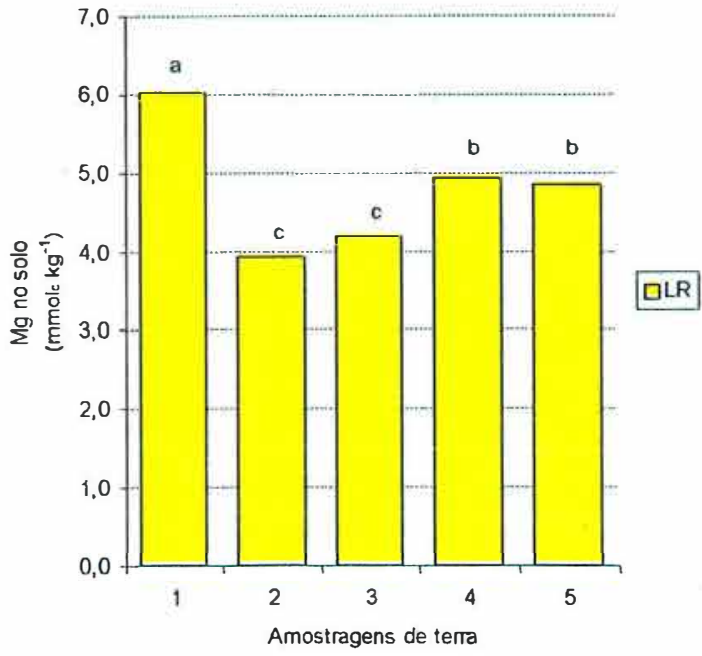

Figura 18 - Variações no teor de $\mathrm{Mg}^{2+}$ no solo em função das aplicações de biossólido dentro de cada tratamento.

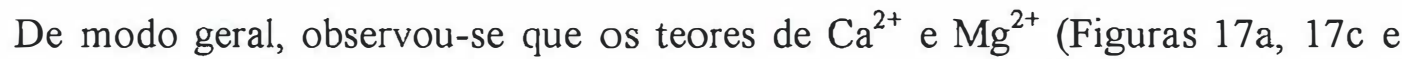
18a, 18c, respectivamente) aumentaram nas amostras de terra LV e LR a medida que se aplicou o biossólido, com exceção do tratamento LR+lodo, que apresentou uma redução brusca no teor de $\mathrm{Mg}^{2+}$ da primeira para a segunda aplicação, aumentando somente a 
partir da quarta aplicação e se igualando na quinta aplicação. Este comportamento no entanto não pode ser vinculado a percolação de água nas caixas nem a lixiviação desta espécie química.

Nos tratamentos LV e LR, constatou-se que os maiores teores de $\mathrm{Ca}^{2+}$ (Figuras $17 \mathrm{~b}$ e $17 \mathrm{~d}$, respectivamente) e $\mathrm{Mg}^{2+}$ (Figuras $18 \mathrm{~b}$ e $18 \mathrm{~d}$, respectivamente) foram observados na primeira amostragem de terra, coincidindo com um dos períodos de menor drenagem de água nas caixas (Figura $8 \mathrm{~b}$ e $8 \mathrm{~d}$, respectivamente) e lixiviação de

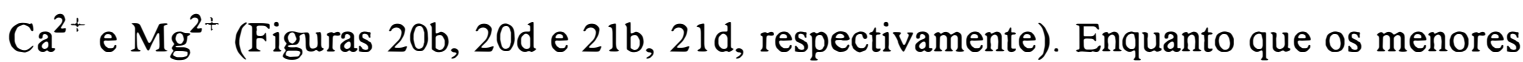
teores de $\mathrm{Ca}^{2+}$, em ambas as amostras de terra (Figuras $17 \mathrm{~b}$ e $17 \mathrm{~d}$, respectivamente), foram observados na terceira amostragem, período de maior drenagem nas caixas (Figuras $8 \mathrm{~b}$ e $8 \mathrm{~d}$ ) e lixiviação de $\mathrm{Ca}^{2-}$ (Figuras $20 \mathrm{~b}$ e $20 \mathrm{~d}$ ). Com relação aos menores teores de $\mathrm{Mg}^{2+}$ no solo, estes foram observados na segunda e terceira amostragem (Figuras 18b e 18d).

Ao se estudar a quantidade de $\mathrm{K}^{+}, \mathrm{Ca}^{2+}$ e $\mathrm{Mg}^{2+}$ no lixiviado, dentro de cada tratamento e ao longo das aplicações (Figuras 19, 20 e 21, respectivamente), constatouse que em todos os tratamentos ocorreram maiores lixiviações de $\mathrm{K}^{+}, \mathrm{Ca}^{2+}{\mathrm{e} \mathrm{Mg}^{2+}}^{2+}$ durante o período de efeito da terceira aplicação de biossólido, exceto no tratamento LR+lodo que foi durante o efeito da quinta aplicação. Além disso, a lixiviação das espécies químicas $\mathrm{K}^{+}, \mathrm{Ca}^{2+}$ e $\mathrm{Mg}^{2+}$ foi bastante influenciada pela quantidade de água lixiviada através das caixas, como pode ser verificado na Figura 8.

Esse comportamento diferenciado do tratamento $\mathrm{LR}+$ lodo em relação ao LV+lodo provavelmente esteja relacionado com a presença de maior teor de argila e óxidos nas amostras de terra LR (Tabela 5), que durante as aplicações promoveram maior retenção dos elementos aplicados. Desta forma, apesar de durante o efeito da terceira aplicação ter percolado mais água nas caixas, durante o efeito da quinta aplicação havia muito maior quantidade de elementos a serem lixiviados. 
(a)

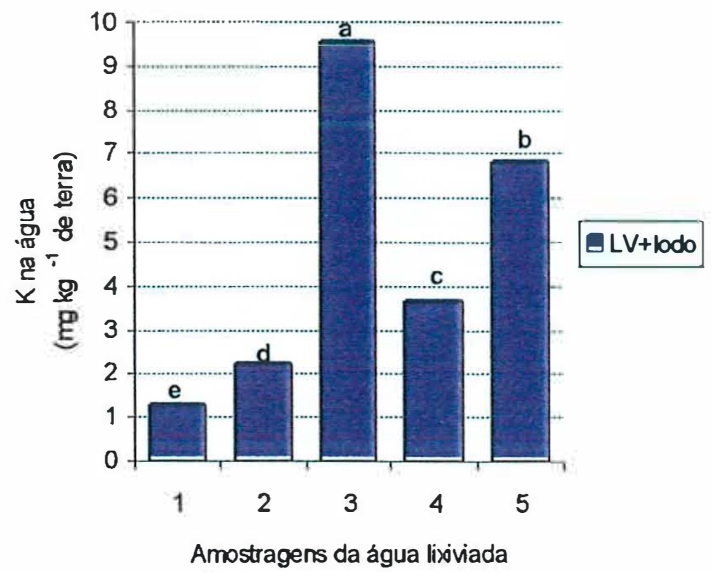

(c)

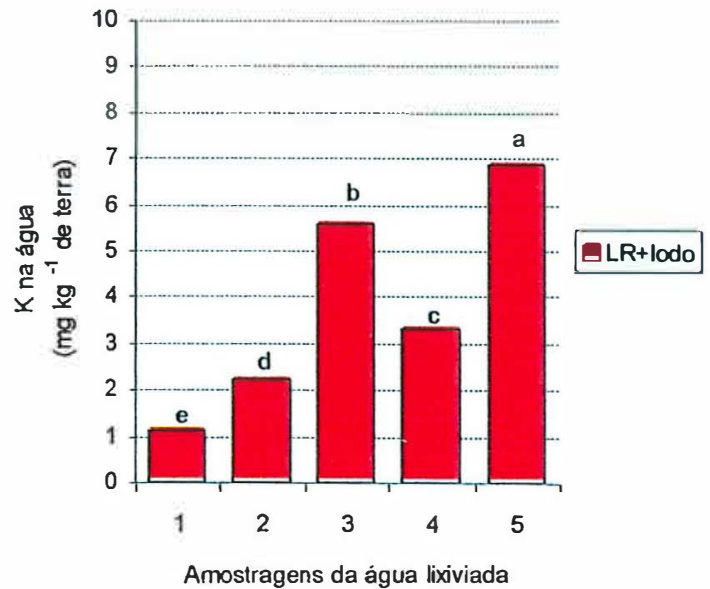

(b)

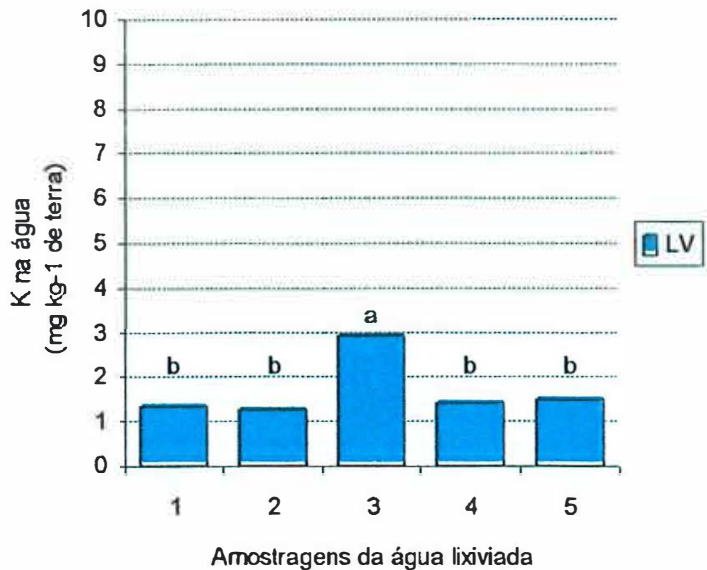

(d)

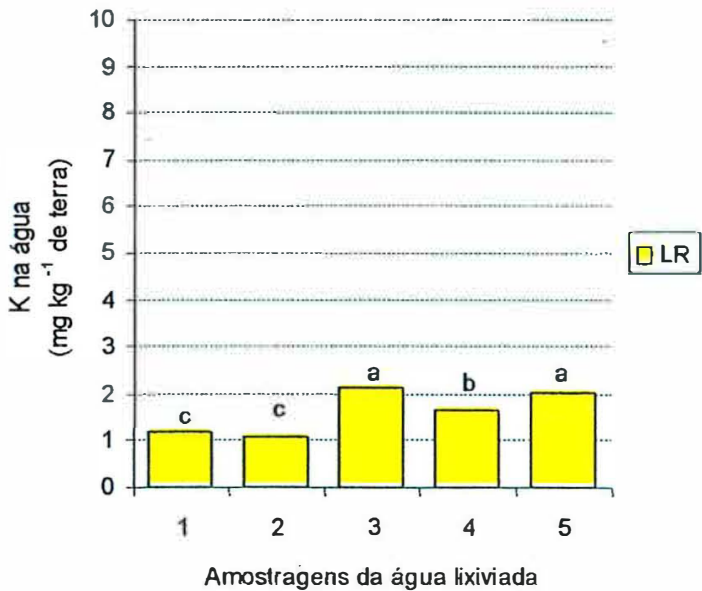

Figura 19 - Variações na quantidade de $\mathrm{K}^{+}$no lixiviado em função das aplicações de biossólido dentro de cada tratamento. 
(a)

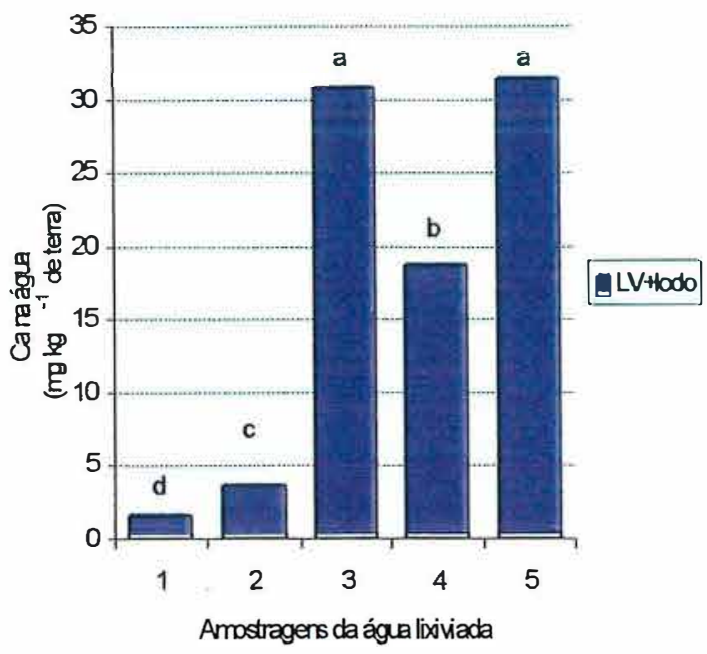

(c)

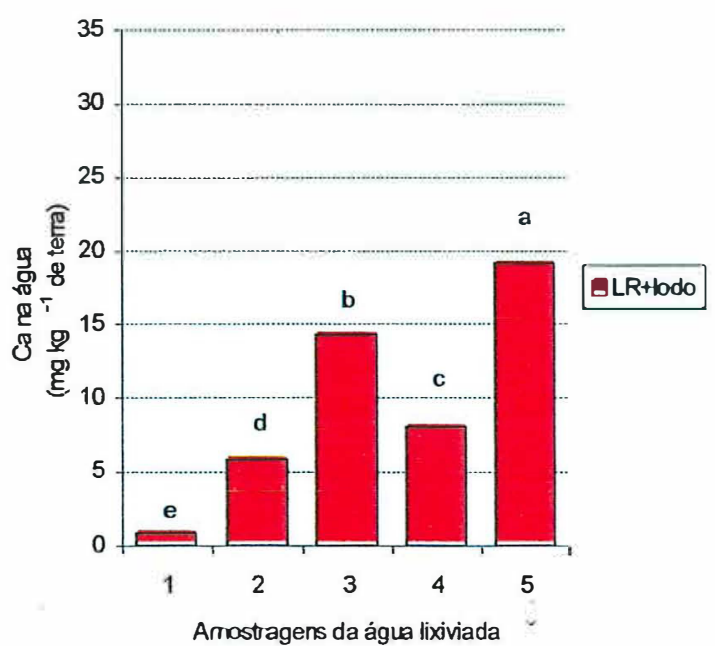

(b)

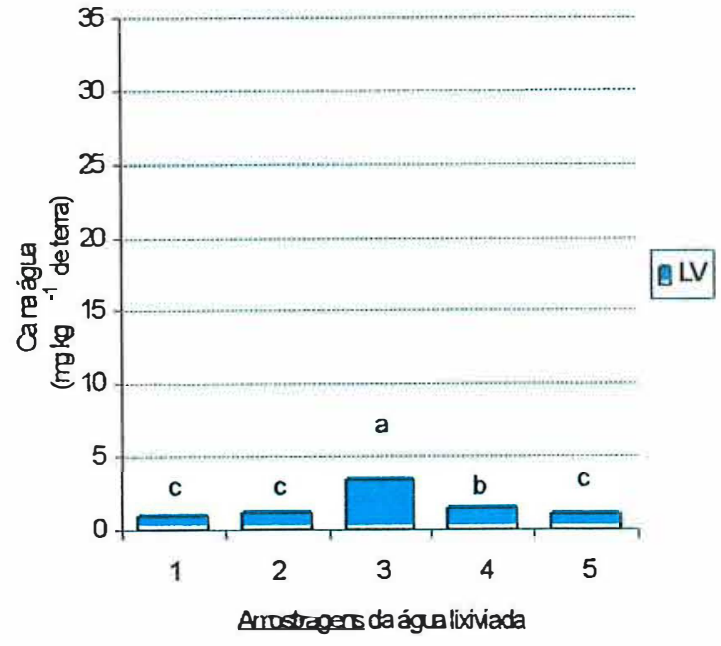

(d)

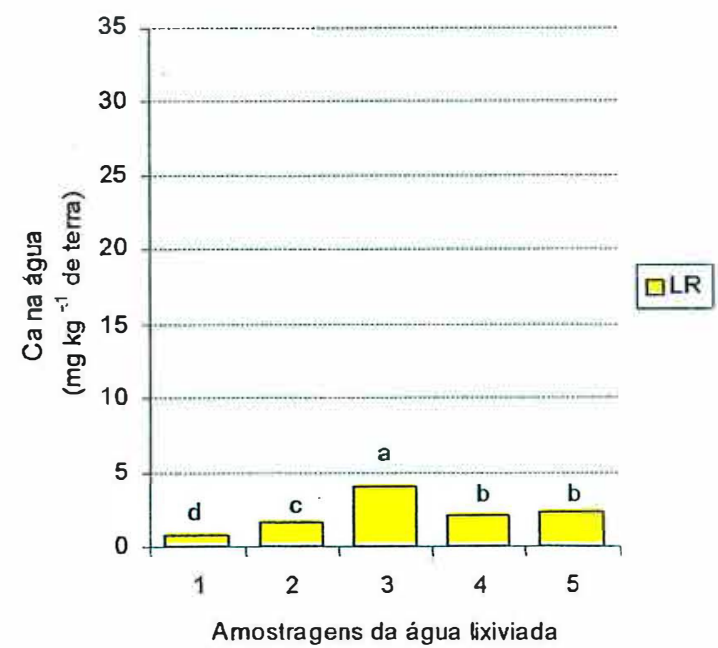

Figura 20 - Variações na quantidade de $\mathrm{Ca}^{2+}$ no lixiviado em função das aplicações de biossólido dentro de cada tratamento. 
(a)

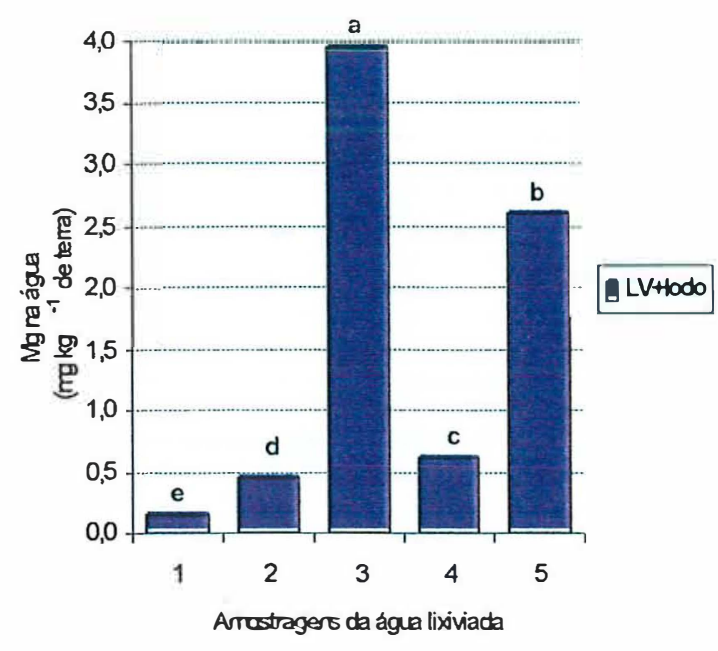

(c)

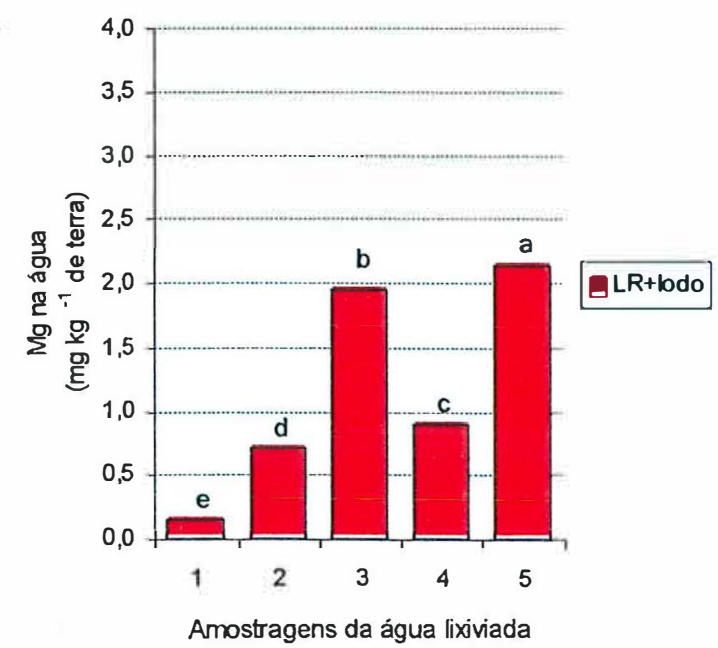

(b)

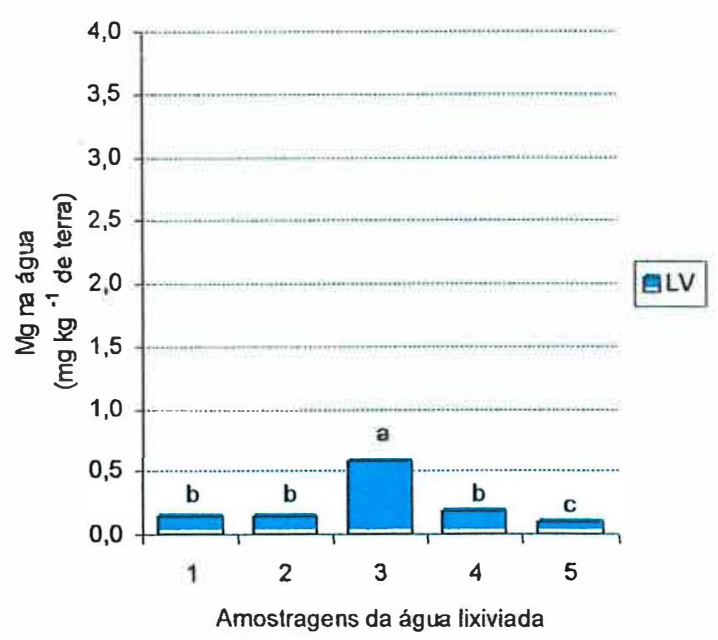

(d)

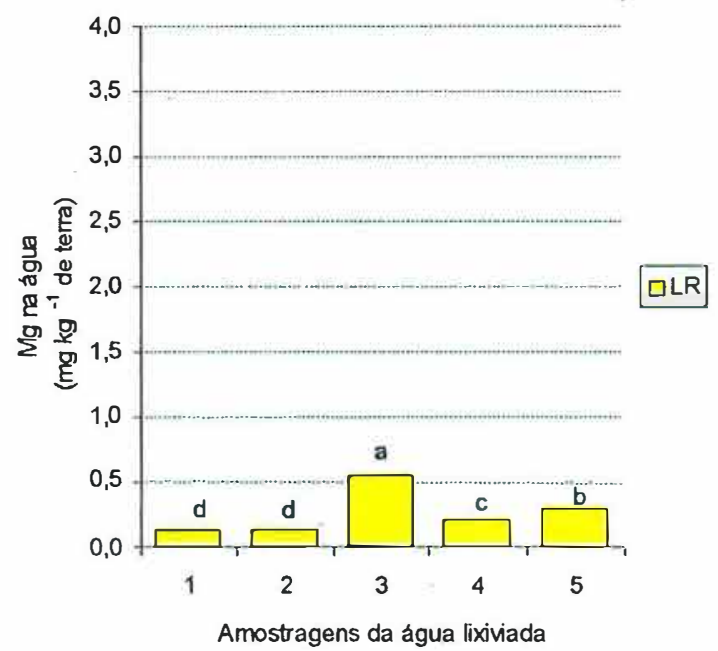

Figura 21 - Variações na quantidade de $\mathrm{Mg}^{2+}$ no lixiviado em função das aplicações de biossólido dentro de cada tratamento.

Embora a precipitação na região de Piracicaba, durante o período de monitoramento da água lixiviada, fosse atípica pode-se inferir que aplicações pesadas de biossólidos em áreas agrícolas podem promover a lixiviação das espécies químicas $\mathrm{K}^{+}$, $\mathrm{Mg}^{2+} \mathrm{e} \mathrm{Ca}^{2+}$, principalmente em solos com baixos teores de argila, óxidos e CTC, 
podendo ser agravado em períodos mais chuvosos. Além disso, podem proporcionar a salinização dos solos, devido a retenção de parte desses cátions adicionados via biossólido, vindo a dificultar o desenvolvimento das plantas.

\subsubsection{Lixiviação de metais}

Os resultados referentes aos metais $\mathrm{Cd}^{2+}, \mathrm{Cr}, \mathrm{Cu}^{2+}, \mathrm{Mn}^{2+}, \mathrm{Ni}^{2}, \mathrm{~Pb}^{2+}$ e $\mathrm{Zn}^{2+}$, na água, estiveram abaixo do limite de detecção do método analítico empregado, o que não significa ausência destes metais na água lixiviada, indica apenas que, por exemplo, a quantidade de $\mathrm{Cd}$ foi inferior a $0,08 \mathrm{mg} \mathrm{L}^{-1}$ e de $\mathrm{Cu}$ e $\mathrm{Zn}$ inferior a $0,014 \mathrm{mg} \mathrm{L}^{-1}$.

Oliveira (1995) também constatou que os teores de $\mathrm{Cd}^{2+}, \mathrm{Cr}, \mathrm{Cu}^{2+} \mathrm{e} \mathrm{Ni}^{2+}$ nos lixiviados coletados foram inferiores ao limite de deteç̧ão do método analítico empregado, ao aplicar doses de no máximo $40 \mathrm{Mg} \mathrm{ha}^{-1}$ de biossólido, base seca, em dois solos distintos, $\mathrm{AQ}$ e LR. Entretanto, o autor detectou a ocorrência de lixiviação de $\mathrm{Mn}^{2+}$ e $\mathrm{Zn}^{2+}$ em ambos os solos, da ordem de 0,78-70,94 e 0,02-1,30 mg volume total lixiviado $^{-1}$, respectivamente, sendo este fenômeno mais evidente no AQ.

Da mesma forma, Bertoncini (1997), ao estudar a lixiviação de metais pesados nos solos $\mathrm{AQ}, \mathrm{LV}$ e LE tratados com $156 \mathrm{Mg} \mathrm{ha}^{-1}$ de biossólido, base seca, também não detectou a presença de $\mathrm{Cd}^{2+}, \mathrm{Cr}$ e $\mathrm{Zn}^{2+}$ nos lixiviados onde se utilizou água como solução percolante. $\mathrm{O}$ autor atribuíu este comportamento ao fato destes elementos não se encontrarem na forma trocável em solos tratados com biossólido. Todavia, com relação aos elementos $\mathrm{Cu}^{2+}$ e $\mathrm{Ni}^{2+}$, o autor detectou $\mathrm{Cu}^{2+}$ somente no líquido oriundo da passagem de água nos tratamentos $\mathrm{AQ}+$ lodo e $\mathrm{LV}+$ lodo, na ordem de 0,3 e 0,2 $\mathrm{mg}$ volume total lixiviado $^{-1}$, respectivamente, e o $\mathrm{Ni}$, no tratamento $\mathrm{AQ}+$ lodo, na ordem de $0,3 \mathrm{mg}$ volume total lixiviado ${ }^{-1}$. Esses teores representaram 0,5 e $0,2 \%$ do $\mathrm{Cu}$ e $1,1 \%$ do $\mathrm{Ni}$ adicionado via biossólido nos respectivos solos.

O fato da não observação de lixiviação de metais no presente trabalho, apesar dos mesmos terem sido aplicados via biossólido (Tabela 9), talvez esteja relacionada com a interação dos seguintes fatores: 
a) elevação do pH do solo, devido a aplicação de biossólido;

b) presença de óxidos de Fe e Al nas amostras de terra;

c) presença de ligantes orgânicos;

d) elevada concentração de $\mathrm{Ca}$ na solução do solo, oriundo da aplicação de biossólido que recebeu, por questão de sanidade e estabilização, grandes quantidades de $\mathrm{CaO}$.

A adição de biossólido proporcionou a elevação do $\mathrm{pH}$ do solo a valores de 7,07,4 , com isto criou-se sítios carregados negativamente nos óxidos de $\mathrm{Fe}$ e $\mathrm{Al}$, nas substâncias orgânicas do solo e nos minerais de argila, resultando no aumento da CTC do solo, assim como ocasionou a maior precipitação de óxidos de Fe e Al. Desta forma, os cátions metálicos $\mathrm{Cd}^{2+}, \mathrm{Cr}, \mathrm{Cu}^{2+}, \mathrm{Ni}^{2+}, \mathrm{Zn}^{2+}$ e $\mathrm{Mn}^{2+}$ podem ter sido adsorvidos e/ou co-preciptados, reduzindo seus teores na solução do solo e conseqüentemente a sua lixiviação.

Ao determinar as taxas de lixiviação a curto prazo dos metais $\mathrm{Cd}^{2+}, \mathrm{Cu}^{2+}, \mathrm{Fe}^{2+}$, $\mathrm{Pb}^{2+}$ e $\mathrm{Zn}^{2+}$, oriundos de biossólidos compostados, em soluções tamponadas com $\mathrm{pH}$ variando de 2,5-7,0 com intervalos de unidade de 0,5, Tackett et al. (1986) constataram a lixiviação $\mathrm{Cd}^{2+}$ e $\mathrm{Zn}^{2+}$ em solos com valores de $\mathrm{pH}$ baixo, com ambos os elementos apresentando maiores aumento de solubilidade na faixa de 5,5-6,0.

Ao estudar o movimento de $\mathrm{Zn}^{2+}$ em solos tratados com biossólidos, Welch \& Lund (1989) também verificaram que o teor total de $\mathrm{Zn}^{2+}$ lixiviado e a profundidade de movimentação deste elemento no solo foram negativamente correlacionados com o pH final do solo.

Conforme Wittbrodt \& Palmer (1996), o aumento do pH dos solos e a presença de substâncias húmicas e fúlvicas proporcionado pela adição de biossólido pode condicionar a redução de $\mathrm{Cr}$ (VI) a forma $\mathrm{Cr}^{3+}$, menos móvel e menos tóxica. Uma vez que, em condições alcalinas ou pouco ácidas, o $\mathrm{Cr}$ (VI) reduzido à forma $\mathrm{Cr}^{3+}$ pode ser precipitado como hidróxidos de fórmulas genéricas $\mathrm{Cr}(\mathrm{OH})_{3}$ ou $\mathrm{Fe}_{\mathrm{x}} \mathrm{Cr}_{1-\mathrm{x}}(\mathrm{OH})_{3}$, podendo também ser complexado junto a moléculas orgânicas ou adsorvido à superficies minerais, tornando-se, desta forma, pouco móvel em um sistema equilibrado. 
Estudando a interação entre ácidos húmicos e metais pesados, Ladonin \&

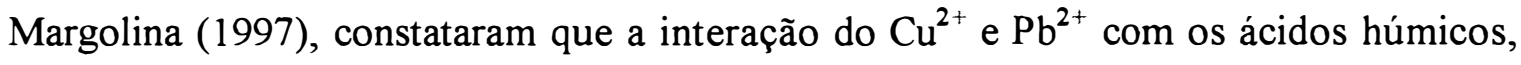
com a formação de ligações predominantemente coordenadas (adsorção específica), foi mais intensiva do que do $\mathrm{Cd}^{2+}$ e $\mathrm{Zn}^{2+}$, cuja ligação é caracterizada por reações do tipo troca iônica (adsorção não especifica). Os autores também demonstraram que a presença do $\mathrm{Ca}^{2+}$ em concentração menor que $0,5 \mathrm{~mol} \mathrm{~L}^{-1}$ reduziu a adsorção de $\mathrm{Zn}^{2+}$ e $\mathrm{Cd}^{2+}$, devido o $\mathrm{Ca}^{2+}$ ocupar as posições de troca não específicas. Entretanto, com a elevação da concentração deste elemento ocorreu uma associação de moléculas de ácido húmico, aumentando a superficie ativa e o aparecimento de novos centros de adsorção específica e não específica, podendo, então, ocorrer a adsorção de $\mathrm{Zn}^{2+}$ e $\mathrm{Cd}^{2+}$. O aumento do $\mathrm{pH}$ do solo aumentou a ionização e a ativação dos grupos funcionais da matéria orgânica, favorecendo essa adsorção.

Além disso, a elevação do $\mathrm{pH}$ até próximo a neutralidade pode ter favorecido a atividade dos microorganismos que oxidam $\mathrm{o} \mathrm{Mn}^{2+}$ solúvel a formas não solúveis, reduzindo a sua presença na solução do solo e portanto a sua lixiviação. Como também pode ter ocorrido a formação de compostos quelatados de $\mathrm{Mn}^{2+}$ insolúveis devido a elevação dos teores de matéria orgânica nas amostras de terra que receberam biossólido. Segundo Kabata-Pendias \& Pendias (1985), a solubilidade do $\mathrm{Mn}^{2+}$ nos solos é altamente dependente do $\mathrm{pH}$ e potencial redox, por isto, a maioria das reações que ocorrem nos solos são de oxidação-redução e hidrólise. Devido a baixa solubilidade dos compostos de $\mathrm{Mn}$ em sistemas oxidantes com valores de $\mathrm{pH}$ próximo a neutralidade, pequenas mudanças nas condições de Eh-pH podem ser muito importante no conteúdo de $\mathrm{Mn}^{2+}$ na solução do solo. Em solos bem drenados a solubilidade do $\mathrm{Mn}^{2+}$ sempre aumenta com o aumento da acidez do solo, porém a habilidade do $\mathrm{Mn}^{2+}$ em formar complexos aniônicos e complexar com ligantes orgânicos pode contribuir para aumentar a solubilidade do $\mathrm{Mn}^{2+}$ na faixa de $\mathrm{pH}$ alcalino. Entretanto, Tisdale et al. (1985) ressaltam que valores de $\mathrm{pH}$ elevado favorece a formação de complexos orgânicos de $\mathrm{Mn}^{2+}$ menos solúveis e a atividade dos microorganismos que oxidam o Mn solúvel a formas não solúveis atinge um máximo próximo de $\mathrm{pH}$ 7. A baixa solubilidade de $\mathrm{Mn}$ em solos alcalinos ricos em matéria orgânica é atribuída a formação de compostos 
quelatados insolúveis de $\mathrm{Mn}^{2+}$.

De acordo com Alloway (1995), $\mathrm{Cu}^{2+}, \mathrm{Mn}^{2+}, \mathrm{Ni}^{2+}$ e $\mathrm{Zn}^{2+}$ podem se encontrar coprecipitados nos óxidos de $\mathrm{Fe}$, enquanto que $\mathrm{Ni}^{2+}$ e $\mathrm{Zn}^{2+}$ nos óxidos de $\mathrm{Mn}$. Os metais $\mathrm{Cr}^{3+}, \mathrm{Cu}^{2+}, \mathrm{Mn}^{2+}, \mathrm{Ni}^{2+}$ e $\mathrm{Zn}^{2+}$ também podem co-preciptar em minerais de argila.

Mattiazzo-Prezotto (1994), ao adicionar os metais $\mathrm{Cd}^{2+}, \mathrm{Cr}, \mathrm{Cu}^{2+} \mathrm{Ni}^{2+}$ e $\mathrm{Zn}^{2+}$ sob a forma de sais em solos com diferentes teores de argila, CTC e pH, não constatou a movimentação de $\mathrm{Cd}^{2+}$ nos tratamentos com TR e no LE, atribuindo tal comportamento a presença nestes solos de maiores conteúdos de óxidos de ferro e alumínio, pois o $\mathrm{Cd}^{2+}$ pode co-precipitar junto à esses óxidos. Também observou que independente da quantidade de $\mathrm{Cd}^{2+}$ aplicada, as concentrações de $\mathrm{Cd}^{2+}$ estiveram abaixo do limite de detecção do método analítico utilizado após a incubação do solo LE com pH inicial de 6,2 .

Com relação a movimentação de $\mathrm{Cu}^{2+}$, o autor verificou que este elemento movimentou-se pouco no perfil do solo, ficando acumulado na camada superficial provavelmente associado à materiais orgânicos insolúveis ou de baixa solubilidade. Além disso, observou que grandes quantidades deste elemento foram retidas particularmente em solos com valores de $\mathrm{pH}$ iguais ou superiores a 5,1 quando da aplicação do metal.

Quanto a lixiviação de $\mathrm{Ni}^{2+}$ e $\mathrm{Zn}^{2+}$, constatou que a quantidade total de $\mathrm{Ni}^{2+} \mathrm{e}$ $\mathrm{Zn}^{2+}$ removida pela lixiviação do TR e LE, que são solos com maiores teores de óxidos de ferro e alumínio, foram sempre inferiores $0,04 \%$ e $0,02 \%$, respectivamente, do total aplicado independente do $\mathrm{pH}$ do solo no momento da adição do metal, da quantidade aplicada e do tempo de incubação. Segundo o autor isto evidenciou a eficiência com que estes solos atuaram na retenção dos metais, vindo apoiar, no caso do $\mathrm{Zn}^{2+}$, a hipótese de que este elemento encontra-se predominantemente presente na forma inorgânica $e$ catiônica livre em solo sob pH 4,0 e que o movimento de $\mathrm{Zn}^{2+}$ nos solos é função da quantidade de óxidos de ferro e alumínio presentes.

A textura das amostras de terra também pode ter contribuído na retenção dos metais, principalmente do $\mathrm{Ni}^{2+}$.

Em estudos com colunas de solo saturado e insaturado, Wech \& Lund (1987) 
analisaram o movimento de $\mathrm{Ni}^{2+}$ em solos tratados com $300 \mathrm{Mg} \mathrm{ha}^{-1}$ de biossólidos, base seca. Os resultados mostram que o movimento de $\mathrm{Ni}^{2+}$ em profundidade foi positivamente correlacionado com o teor de areia dos solos e negativamente correlacionado com os teores de argila, silte e com $\mathrm{pH}$ final do solo.

Avaliando a adsorção competitiva dos íons $\mathrm{Co}^{2+}, \mathrm{Cu}^{2+} \mathrm{e} \mathrm{Ni}^{2+}$ em solos saturados com $\mathrm{Ca}^{2+}$, Harter (1992) verificou que a adsorção de $\mathrm{Ni}^{2+}$ foi equivalente a liberação de $\mathrm{Ca}^{2+}$. Aparentemente o $\mathrm{Ni}^{2+}$ foi retido por mecanismos de troca, enquanto que o $\mathrm{Co}^{2+} \mathrm{e} o$ $\mathrm{Cu}^{2+}$, por mecanismos mais complexos. $\mathrm{O} \mathrm{Cu}^{2+}$ foi seletivamente adsorvido da solução contendo $\mathrm{Ca}^{2+}$, enquanto que o $\mathrm{Co}^{2+}$ e o $\mathrm{Ni}^{2+}$ foram capazes de competir com $\mathrm{Ca}^{2+}$ somente em diluições muito baixas. $\mathrm{O}$ autor concluiu que a manutenção do $\mathrm{pH}$ do solo próximo a neutralidade nem sempre é a melhor estratégia para minimizar a mobilidade do metal pesado, pois alguns íons são incapazes de competir com o $\mathrm{Ca}^{2+}$ pelos locais de sorção em forças iônicas representativas de $\mathrm{pH}$ próximo a neutralidade. Assim, enquanto a solubilidade absoluta pode ser controlada, a mobilidade dos íons em solução pode ser aumentada pelo aumento da força iônica da solução com o $\mathrm{pH}$ próximo da neutralidade.

Segundo Hue (1995), o movimento de metais pesados, como resultado de aplicações de biossólido ao solo, é muito limitado e somente é observado em solos arenosos, ácidos, com baixo teor de matéria orgânica que recebem grandes aplicações de biossólido associadas à uma elevada precipitação ou irrigação.

No caso do estudo da lixiviação de metais pode-se inferir que os metais adicionados aos solos LV e LR foram retidos por adsorção ou co-precipitação, indicando que até a dose de $388 \mathrm{Mg} \mathrm{ha}^{-1}$ de biossólido, base seca, não ocorreu a presença desses elementos na água lixiviada, o que demonstra a capacidade de retenção de metais pesados por estes solos.

\subsection{Lixiviação de $\mathrm{N}-\mathrm{NO}_{3}^{-}$}

Como testes preliminares indicaram que praticamente a totalidade do $\mathrm{N}$ presente nos lixiviados, mais de $97 \%$, estava na forma $\mathrm{N}-\mathrm{NO}_{3}{ }^{\circ}$, o estudo da lixiviação de $\mathrm{N}$ se 
referirá a lixiviação de $\mathrm{N}^{-\mathrm{NO}_{3}}{ }^{-}$. Esta constatação está de acordo com Riekerk (1978) e Medalie et al. (1994), que ao aplicarem biossólido em um solo florestal verificaram que o ion móvel predominante foi o $\mathrm{N}-\mathrm{NO}_{3}$.

A lixiviação de $\mathrm{N}^{-\mathrm{NO}_{3}}{ }^{-}$foi influenciada pela interação tratamentos $\mathrm{x}$ aplicações, sendo comprovado estatisticamente pela significância do teste $\mathrm{F}$ ao nível de $1 \%$ (Apêndice 1.3).

Durante o período de influência da primeira aplicação, ao se comparar as quantidades médias de $\mathrm{N}^{-} \mathrm{NO}_{3}{ }^{-}$presentes na água lixiviada dos tratamentos com e sem biossólido (Apêndice 1.4), verificou-se que a aplicação de biossólido não aumentou significativamente a quantidade de $\mathrm{N}-\mathrm{NO}_{3}{ }^{-}$lixiviado. Da mesma forma, não se constatou diferença significativa nas quantidades médias de $\mathrm{N}^{-\mathrm{NO}_{3}}{ }_{3}$ na água que percolou o $\mathrm{LV}$ ou LR, ao se comparar as amostras de terra LV e LR dentro dos tratamentos com e sem biossólido (Apêndice 1.4). Este comportamento pode estar relacionado a condição de acidez do solo, considerada alta nos tratamentos testemunha e baixa nos tratamentos com biossólido (Figura 9) e ao curto período de monitoramento, 25 dias após a aplicação, determinado pela precipitação. Segundo Victoria et al. (1992), o processo de oxidação de amônio a nitrato é mediado por microrganismos sensiveis a valores baixos de $\mathrm{pH}$, sendo necessário um $\mathrm{pH}$ na faixa de 7,0-7,6 para que estes microrganismos atinjam seu crescimento ideal. Oliveira (1995), constatou que a Areia Quartzosa ao ser tratada com biossólido apresentou as maiores taxas de degradação, representadas pelos processos de nitrificação, aos 21 dias, enquanto que o Latossolo Roxo, aos 42 dias, sugerindo que as formas nitrogenadas podem se perder muito rapidamente no solo Areia Quartzosa.

Assim, a primeira aplicação de $72 \mathrm{Mg} \mathrm{ha}^{-1}$ de biossólido, base seca, não foi suficiente para elevar o nível de $\mathrm{N}_{-} \mathrm{NO}_{3}{ }^{-}$na água que percolou nas caixas, durante o período de monitoramento de 25 dias após a aplicação (Apêndice 1.4 e Figura 22).

Entretanto, após a quinta aplicação, ao se comparar os tratamentos com e sem biossólido (Apêndice 1.4 e Figura 22), verificou-se as maiores lixiviações de $\mathrm{N}^{-\mathrm{NO}_{3}}{ }^{-}$ nos tratamentos que receberam biossólido. A quantidade lixiviada de $\mathrm{N}^{-\mathrm{NO}_{3}}{ }^{-}$nos tratamentos $\mathrm{LV}+$ +lodo e $\mathrm{LR}+$ lodo correspondeu, respectivamente, a $6,7 \%$ e $6,0 \%$ do total 
de $\mathrm{N}$ aplicado na quinta dose. Isto demonstra que durante as aplicações sucessivas de biossólido intensificou-se o processo de nitrificação, em decorrência da oxidação do $\mathrm{N}$-orgânico acumulado e da elevação do $\mathrm{pH}$ do solo $(\mathrm{pH} \approx 7,4)$, que favoreceu os microrganismos responsáveis pela nitrificação. Deste modo, o efeito residual das quantidades aplicadas de biossólido, que totalizaram $388 \mathrm{Mg} \mathrm{ha}^{-1}$ de biossólido, base seca, elevou acentuadamente o nível de $\mathrm{N}_{-} \mathrm{NO}_{3}{ }^{-}$no lixiviado.

Nesta mesma aplicação, analisando apenas os tratamentos testemunha (Apêndice 1.4 e Figura 22), constatou-se que existe uma lixiviação natural de $\mathrm{N}^{-\mathrm{NO}_{3}}{ }^{-}$nos solos, oriundo da mineralização e nitrificação da matéria orgânica do próprio solo. Neste caso, a lixiviação de $\mathrm{N}_{-} \mathrm{NO}_{3}{ }^{-}$foi maior no LR. Este comportamento pode estar relacionado ao maior teor inicial de matéria orgânica desta amostra de terra, quando comparada a amostra LV (Tabela 4).

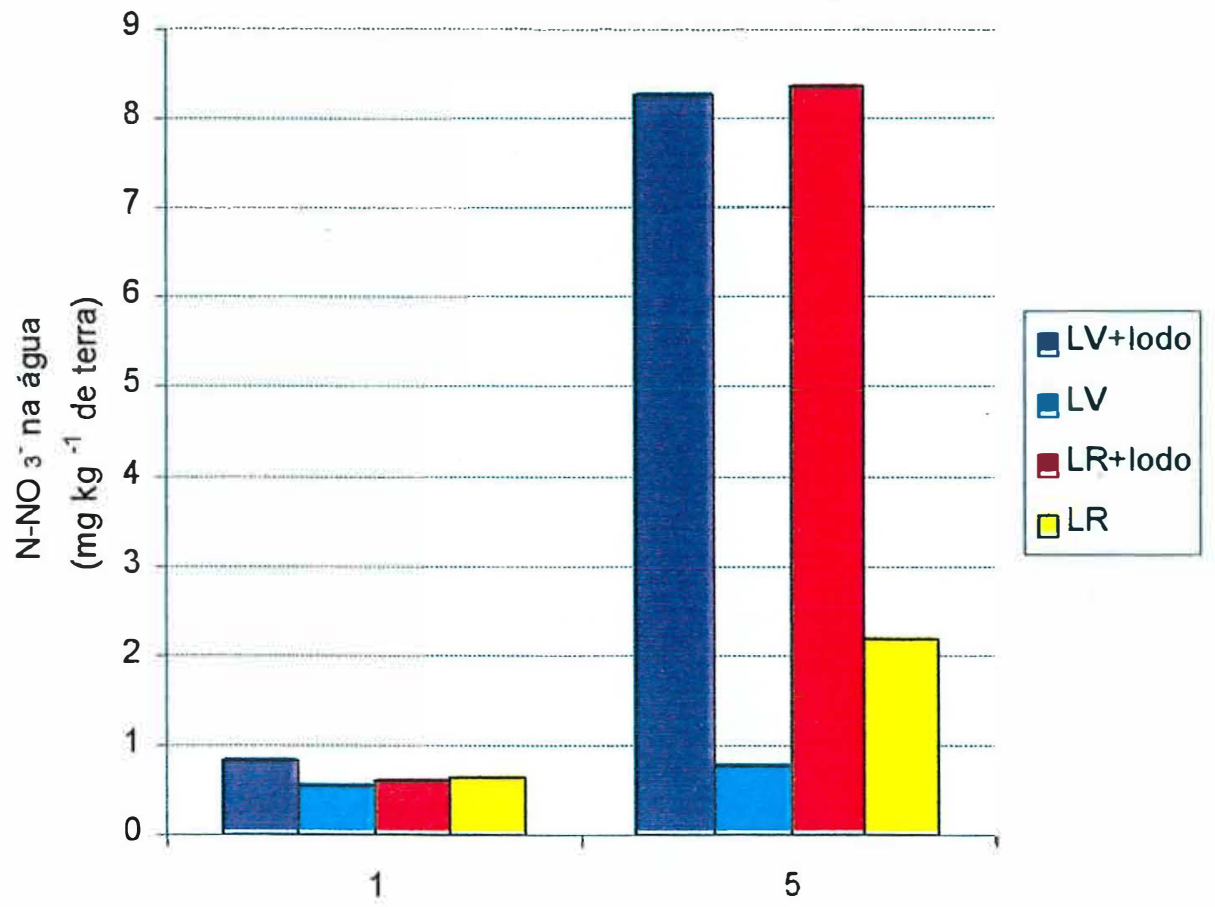

Amostragens da água lixiviada

Figura 22 - Variações na quantidade de $\mathrm{N}^{-\mathrm{NO}_{3}}{ }^{-}$no lixiviado em função das aplicações de biossólido. 
Analisando a quantidade de $\mathrm{N}_{-} \mathrm{NO}_{3}{ }^{-}$no lixiviado, dentro de cada tratamento e ao longo das aplicações (Figura 23), verifica-se que em todos os tratamentos, inclusive nas testemunhas, a quantidade de nitrato presente no lixiviado foi maior na quinta amostragem em relação a primeira. Como não houve adição de matéria orgânica aos tratamentos testemunha e a percolação de água nas caixas foi praticamente a mesma, em ambos os períodos, não se pode atribuir as variações na quantidade de nitrato da água lixiviada à adição de materiais orgânicos.

A fim de se ter uma noção se as concentrações de $\mathrm{N}-\mathrm{NO}_{3}{ }^{-}$encontrados nos lixiviados eram altas ou baixas, estas foram comparadas com os limites estabelecidos pela legislação americana, devido a falta de uma legislação própria. Verificou-se (Tabela 24) que em todos os tratamentos, nos dois períodos de monitoramento, as concentrações de $\mathrm{N}_{-} \mathrm{NO}_{3}{ }^{-}$excederam o limite máximo permitido de $10 \mathrm{mg} \mathrm{L}^{-1}$, estabelecido pela USEPA para a água potável e contaminação de aqüíferos (USEPA, 1993). A aplicação sucessiva de biossólido contribuiu realmente para a elevação da concentração de $\mathrm{N}-\mathrm{NO}_{3}{ }^{-}$, a níveis muito superiores ao estabelecido pela legislação americana. Desta forma, a possibilidade de haver contaminação de aqüíferos com esta prática deve ser considerada, independentemente do solo no qual será feita a adição de biossólido.

Tabela 24. Quantidade de $\mathrm{N}_{-} \mathrm{NO}_{3}{ }^{-}$removida pela percolação da água da chuva. Valores médios de quatro repetições, expressos em $\mathrm{mg} \mathrm{L}^{-1}$ e em $\mathrm{mg}$ volume total lixiviado ${ }^{-1}$.

\begin{tabular}{lcc}
\hline Tratamentos & $\mathrm{I}^{\mathrm{a}}$ aplicação & $5^{\mathrm{a}}$ aplicação \\
\hline LV+lodo & 22 & 95 \\
LV & 11 & 23 \\
LR+lodo & 12 & 96 \\
LR & 13 & 46 \\
\hline \hline LV+lodo & +58 & 4.597 \\
LV & 305 & 438 \\
LR+lodo & 290 & 4.067 \\
LR & 319 & 1.065 \\
\hline
\end{tabular}


(a)

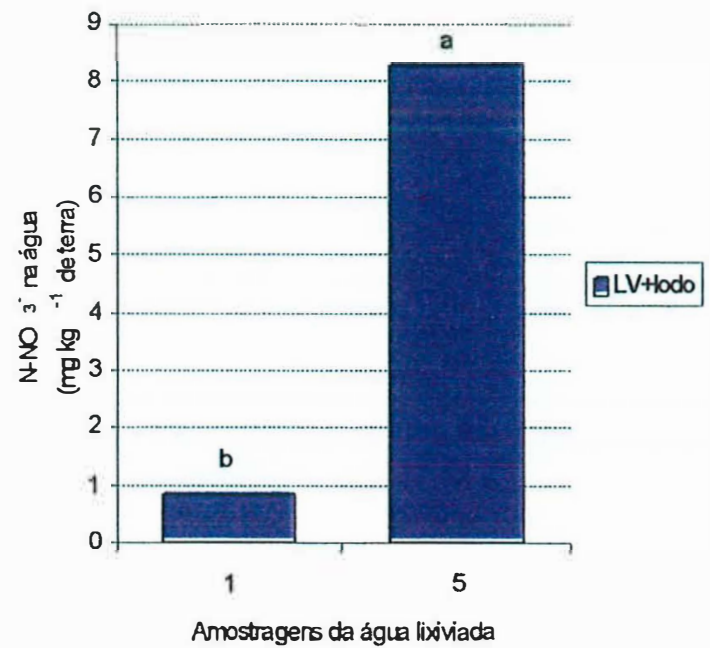

(c)

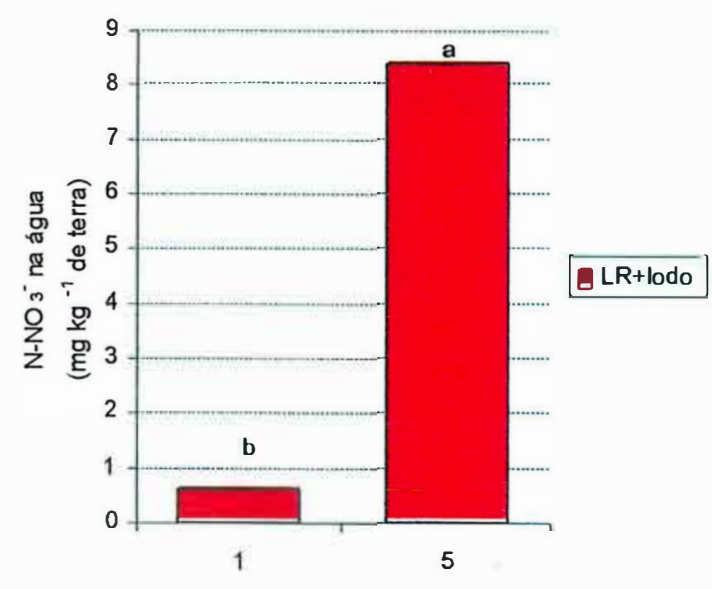

Amostragens da água lixiviada (b)

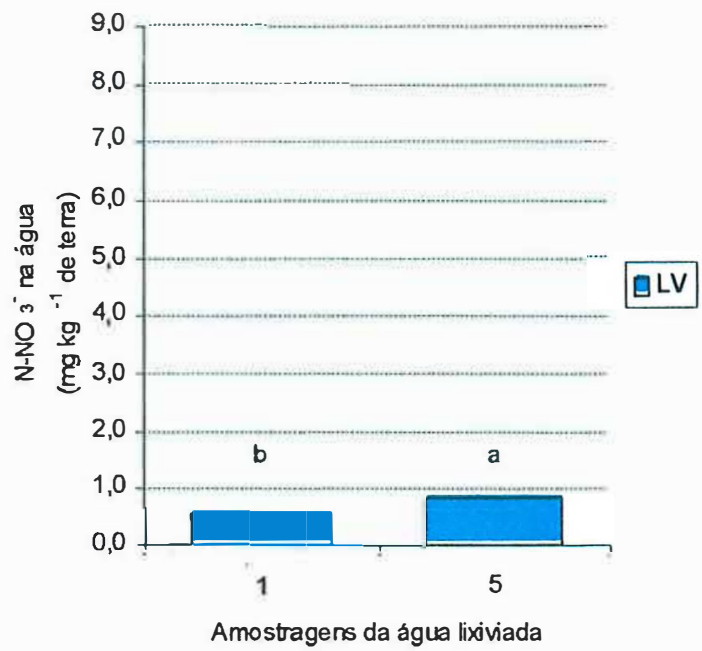

(d)

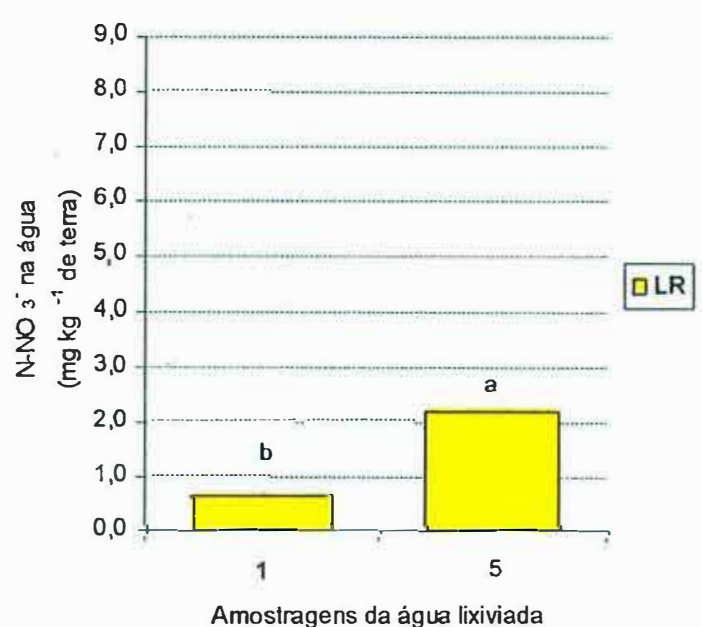

Figura 23 - Variações na quantidade de $\mathrm{N}_{-} \mathrm{NO}_{3}{ }^{-}$no lixiviado em função das aplicações de biossólido dentro de cada tratamento. 


\subsection{Métodos de extração e fitodisponibilidade de metais}

\subsubsection{Avaliação do teor total e disponível de metais através de extratores}

Embora tenham sido realizadas sucessivas aplicações de biossólido, totalizando $388 \mathrm{Mg} \mathrm{ha}^{-1}$, base seca, as extrações feitas com as soluções $\mathrm{HCl} \mathrm{0,1} \mathrm{mol} \mathrm{L}^{-1}$, Mehlich $3 \mathrm{e}$ DTPA pH 7,3, em todos os tratamentos, não resultaram em quantidades detectáveis (nd) de $\mathrm{Pb}^{2+}$ pelo método analítico empregado, razão pela qual não são apresentados dados relativos a estas determinações. O teor total determinado por água régia também esteve abaixo do limite de deteç̧ão.

Também não foi possivel detectar $\mathrm{Cr}$ e $\mathrm{Cd}^{2+}$ nos tratamentos testemunha com nenhum dos extratores utilizados, bem como nos tratamentos com biossólido com DTPA pH 7,3 e no tratamento LR+lodo quando submetido a extração com $\mathrm{HCl}$ 0,1 $\mathrm{mol} \mathrm{L}^{-1}$.

A não remoção de $\mathrm{Cr}$, pela solução DTPA $\mathrm{pH} 7,3 \mathrm{em}$ todos os tratamentos também foi constatada por Oliveira (1995), enquanto Bertoncini (1997) em solos AQ, LV e LE sem biossólido também não constatou a remoção do elemento pelos extratores

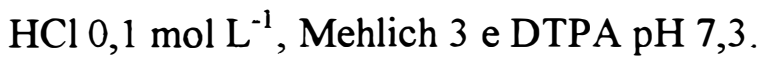

No presente estudo no tratamento $\mathrm{LR}+$ lodo não foi possivel extrair $\mathrm{Cd}^{2+}$ com a solução de $\mathrm{HCl} 0,1 \mathrm{~mol} \mathrm{~L}^{-1}$, provavelmente, devido a elevação do $\mathrm{pH}$ das amostras de terra, proporcionado pelas sucessivas aplicações de biossólido $(\mathrm{pH} \approx 7,4)$ e conseqüente co-precipitação de $\mathrm{Cd}^{2+}$ com os óxidos de $\mathrm{Fe}$ e $\mathrm{Mn}$, que ocorreu naturalmente em maior quantidade no LR por este solo apresentar maior teor de óxidos (Tabela 5). A não remoção de $\mathrm{Cd}^{2+}$ indica a força com que este elemento se encontra retido.

Todavia, Oliveira (1995) conseguiu remover o $\mathrm{Cd}^{2+}$ presente nos solos AQ e LR que receberam as maiores doses de biossólido, por meio dos extratores $\mathrm{HCl} 0,1 \mathrm{~mol} \mathrm{~L}^{-1} \mathrm{e}$ DTPA pH 7,3 (0,31-1,49 $\mathrm{mg}$ de $\mathrm{Cd}$ ), sendo as menores quantidades deste metal obtidas com DTPA pH 7,3. Cabe no entanto ressaltar que o $\mathrm{pH}$ final do solo dos tratamentos que receberam as maiores doses de biossólido oscilou de 4,6-7,2 no AQ e 5,9-7,3 no LR, o que pode ter favorecido a extração de $\mathrm{Cd}^{2+}$ no $\mathrm{LR}$.

Os teores de $\mathrm{Cd}^{2+}$ encontrados nos tratamentos que receberam biossólido foram 
influenciados somente pelos métodos de extração, sendo comprovado estatisticamente pela significância do teste $\mathrm{F}$ ao nível de $1 \%$ (Apêndice 3.3).

Analisando aos teores solúveis de $\mathrm{Cd}^{2+}$ no solo (Figura 24), constatou-se que as soluções DPTA pH 7,3, Mehlich 3 e $\mathrm{HCl} 0,1 \mathrm{~mol} \mathrm{~L} \mathrm{~L}^{-1}$ extraíram quantidades significativamente equivalentes até a profundidade de $20 \mathrm{~cm}$, sendo respectivamente 0,0 , 0,9 e $0,5 \mathrm{mg} \mathrm{kg}^{-1}$ de Cd. Tal comportamento não foi observado por Bertoncini (1997). Segundo o autor, o $\mathrm{HCl} 0,1 \mathrm{~mol} \mathrm{~L}^{-1}$ extraiu teores de $\mathrm{Cd}^{2+}\left(\approx 1,4 \mathrm{mg} \mathrm{kg}^{-1}\right)$ da mesma ordem de grandeza que o removido pelo método denominado via seca, que expressa o teor total do elemento, quantidade esta praticamente igual a adicionada aos solos via biossólido. A solução Mehlich 3 não conseguiu remover o $\mathrm{Cd}^{2+}$ presente nos solos, enquanto que o DTPA pH 7,3 consegui extrair dos solos em média 0,5 $\mathrm{mg} \mathrm{kg}^{-1}$ de Cd.

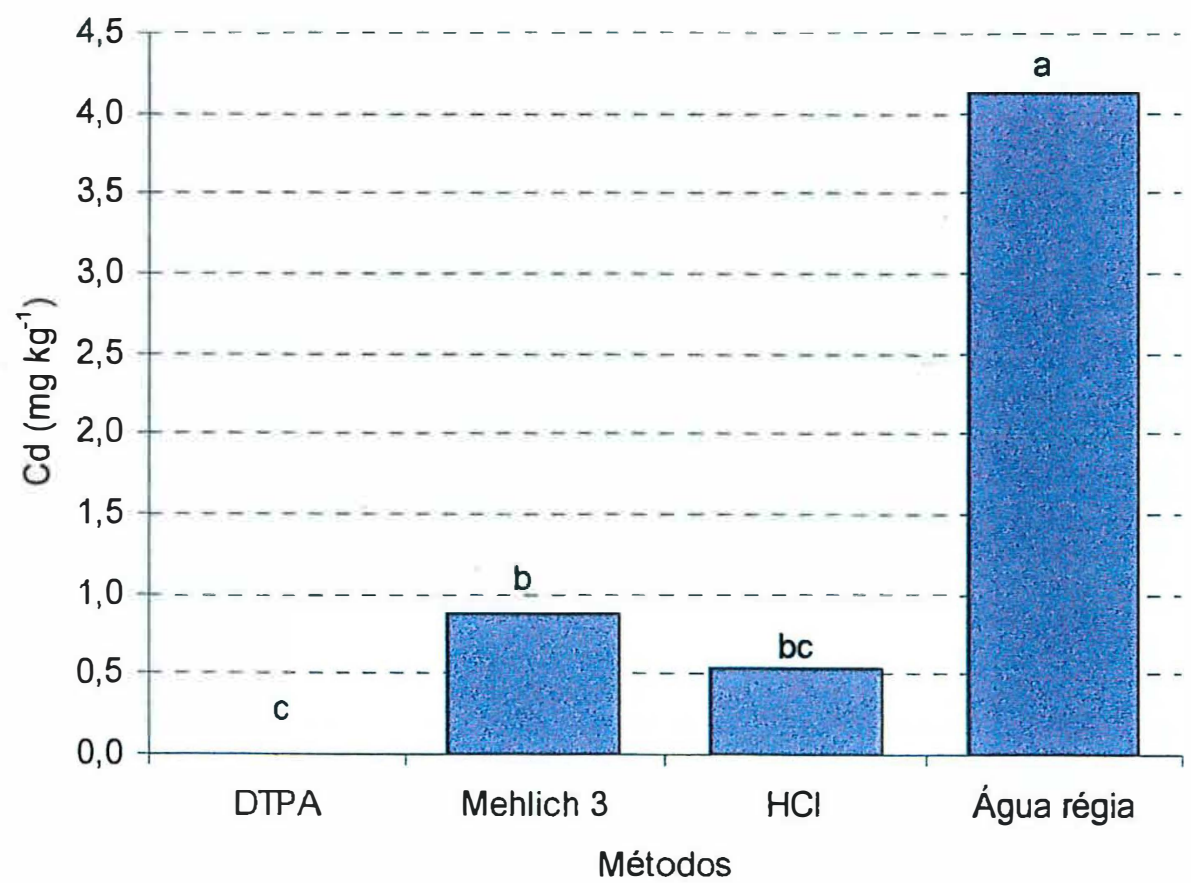

Figura 24 - Variações nos teores médios de $\mathrm{Cd}$ removidos pör diversos métodos de extração em função das aplicações de biossólido. 
Os teores de $\mathrm{Cr}, \mathrm{Cu}^{2+}, \mathrm{Mn}^{2+}, \mathrm{Ni}^{2+}$ e $\mathrm{Zn}^{2+}$ removidos dos solos por diversos extratores foram significativamente influenciados $(\alpha \leq 0,01)$ pela interação entre os tratamentos e os métodos de extração de metais (Apêndice 3.3 e 3.4).

Cabe ressaltar que com relação ao metal $\mathrm{Ni}^{2+}$, este foi removido por todos os métodos de extração estudados em quantidades detectáveis apenas nos tratamentos que receberam biossólido. Este fato também foi observado por Bertoncini (1997).

Após as sucessivas aplicações de biossólido, ao se comparar os teores de metais dos tratamentos com e sem biossólido (Apêndice 3.5 e Figuras 25 e 26), verificou-se que todos os métodos de extração removeram significativamente maiores teores de $\mathrm{Cr}, \mathrm{Cu}^{2+}$, $\mathrm{Ni}^{2+}$ e $\mathrm{Zn}^{2+}$ dos tratamentos que receberam biossólido. Com exceção do DTPA pH 7,3 que não conseguiu remover o metal $\mathrm{Cr}$ de nenhum dos tratamentos.

Roca \& Pomares (1991), também observaram que a adição de biossólido resultou em aumentos significativos de $\mathrm{Zn}^{2+}$ (nos três anos de avaliação) e $\mathrm{Cd}^{2+}$ (a partir do segundo ano), sendo detectados por todos os métodos de extração utilizados, dentre eles DTPA pH 7,3, $\mathrm{HCl} 0,1 \mathrm{~mol} \mathrm{~L}^{-1}$ e ágıa régia. $\mathrm{Na}$ determinação de $\mathrm{Ni}^{2+}$, os autores somente não detectaram aumentos significativos com a utilização da água régia.

Com relação a remoção de $\mathrm{Mn}^{2+}$ (Apêndice 3.5 e Figura 25b), constatou-se, ao se comparar os teores deste metal nos tratamentos com e sem biossólido, somente diferença significativa com o extrator DTPA pH 7,3, sendo os menores teores de $\mathrm{Mn}^{2+}$ extraídos dos tratamentos que receberam biossólido. Este comportamento também foi observado por Silva (1995) e pode estar relacionado ao $\mathrm{pH}$ final destes tratamentos, o qual foi superior $(\mathrm{pH} \approx 7,4)$ ao dos tratamentos testemunha $(\mathrm{pH} \approx 4,8)$ (Figura 10$)$. Conforme Tisdale et al. (1985), valores de pH altos favorecem a formação de complexos orgânicos mais estáveis. A atividade dos microrganismos que oxidam o manganês solúvel a formas indisponíveis atinge o máximo próximo de valores de $\mathrm{pH} 7,0$. Hungria \& Urquiaga (1992) também afirmam que a oxidação biológica do $\mathrm{Mn}^{2+}$ têm importância entre pH 5,5 e 9,0 e é mais rápida em valores próximos da neutralidade. Os óxidos produzidos microbiologicamente parecem apresentar uma forma intermediária entre a tri e tetravalente. 
(a)

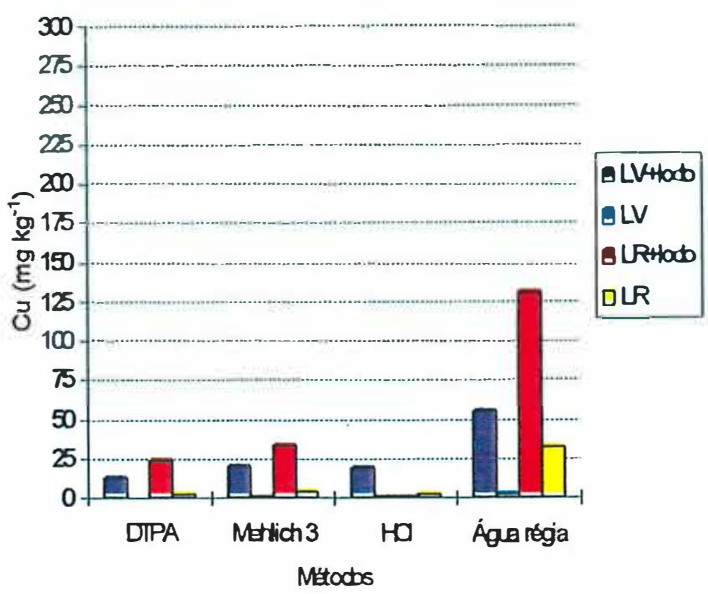

(b)

(c)
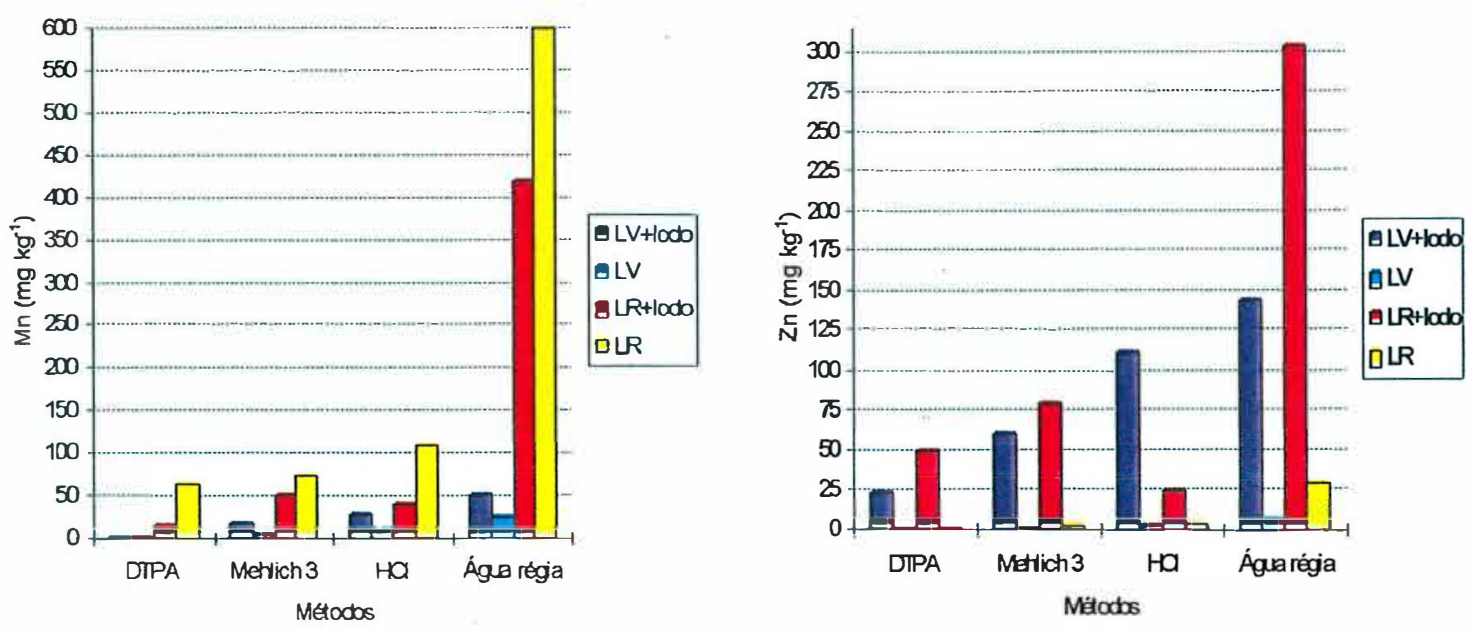

Figura 25 - Variações nos teores médios de $\mathrm{Cu}$ (a), $\mathrm{Mn}$ (b) e $\mathrm{Zn}$ (c) removidos por diversos métodos de extração em função das aplicações de biossólido.

Comparando-se somente os tratamentos que receberam biossólido (Apêndice 3.5 e Figuras 25 e 26), observou-se que na determinação do teores solúveis os extratores

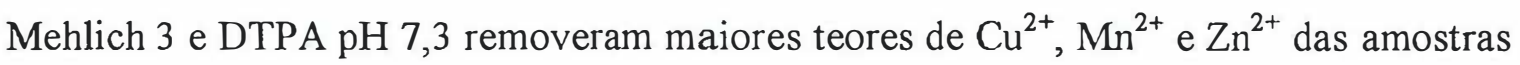
de terra $\mathrm{LR}$, do que das $\mathrm{LV}$, enquanto que o extrator $\mathrm{HCl} 0,1 \mathrm{~mol} \mathrm{~L}^{-1}$ removeu maiores 
teores de $\mathrm{Cr}, \mathrm{Cu}^{2+}, \mathrm{Ni}^{2+}$ e $\mathrm{Zn}^{2+}$ das amostras de terra LV. Quanto a determinação dos teores totais, verificou-se que a água régia removeu os maiores teores de $\mathrm{Cr}, \mathrm{Cu}^{2+}$, $\mathrm{Mn}^{2+}, \mathrm{Ni}^{2+}$ e $\mathrm{Zn}^{2+}$, das amostras de terra LR. Verificou-se com base nos resultados apresentados pelas testemunhas de ambas as amostras de terra que as quantidades naturais de $\mathrm{Cu}^{2+}, \mathrm{Mn}^{2+}$ e $\mathrm{Zn}^{2+}$ foram bem maiores no LR (Apêndice 3.5 e Figura 25).

(a)

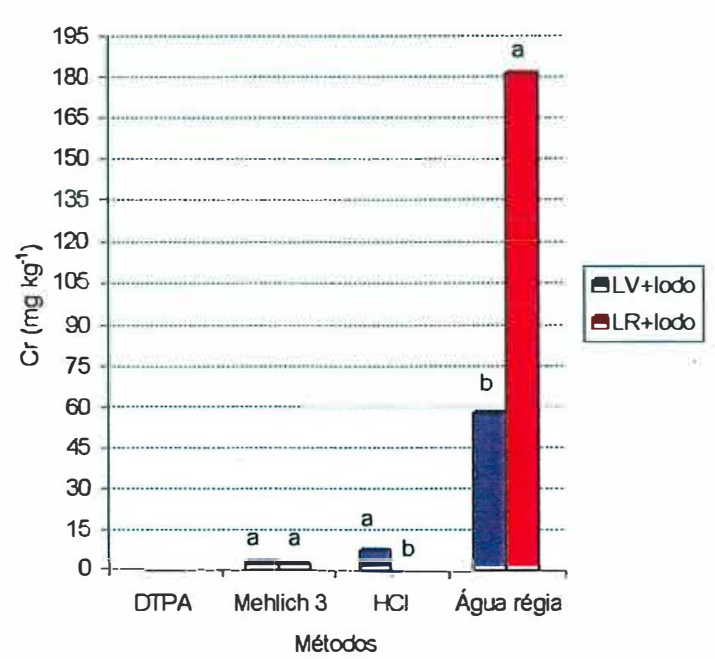

(b)

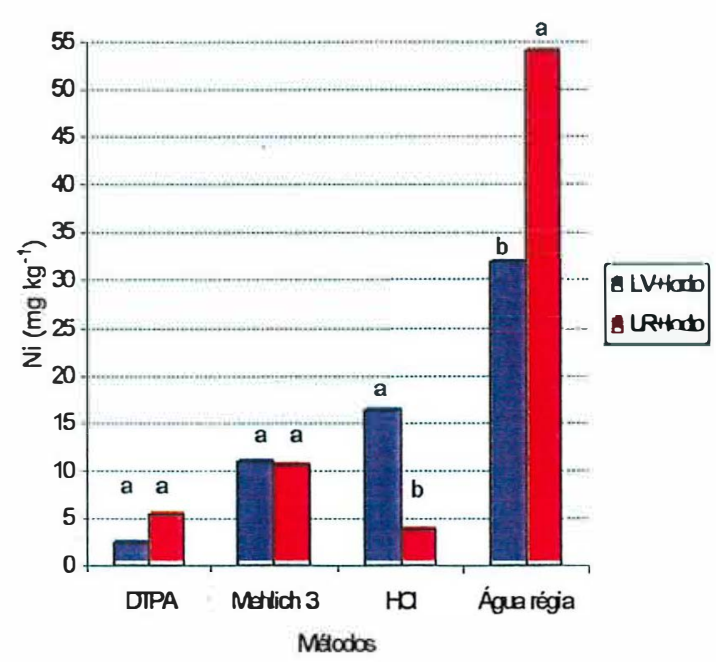

Figura 26 - Variações nos teores médios de $\mathrm{Cr}$ (a) e Ni (b) removidos por diversos métodos de extração em função das aplicações de biossólido.

Ao se confrontar as testemunhas (Apêndice 3.5 e Figura 25), também constatouse que todos os métodos de extração removeram os maiores teores de $\mathrm{Cu}^{2+}$ e $\mathrm{Mn}^{2+}$ nas amostras de terra LR. Entretanto, na remoção de $\mathrm{Zn}^{2+}$ verificou-se diferença significativa somente na determinação do teor total com a solução de água régia, sendo os maiores teores de $\mathrm{Zn}^{2+}$ extraídos dos tratamentos LR.

Essa maior extração de $\mathrm{Cu}^{2+}, \mathrm{Mn}^{2+}$ e $\mathrm{Zn}^{2+}$ nas amostras de terra $\mathrm{LR}$ deve-se principalmente ao material de origem deste solo. Trabalhando com solos do Estado de São Paulo, Valadares \& Catani (1974) e Valadares (1975) encontraram, respectivamente, em Latossolos Roxos, oriundos de rochas básicas, teores médios de 
$\mathrm{Zn}^{2+}$ na ordem de $89-215 \mathrm{mg} \mathrm{kg}^{-1}$ e teores médios de $\mathrm{Cu}^{2+}$ de $89-218 \mathrm{mg} \mathrm{kg}^{-1}$, ambos obtidos com ataque perclórico-fluorídrico. Em Latossolos Vermelho Amarelo derivados de sedimentos modernos e sedimentos modernos arenosos, os autores encontraram, respectivamente, teores médios totais de $8-50 \mathrm{mg} \mathrm{kg}^{-1}$ para o $\mathrm{Zn}^{2+}$ e de 4-17 $\mathrm{mg} \mathrm{kg}^{-1}$ para o $\mathrm{Cu}^{2+}$. No Paraná, o teor total de $\mathrm{Mn}^{2+}$, segundo informações de Borkert (1991), varia de $50 \mathrm{mg} \mathrm{kg}^{-1}$ em latossolo oriundo de arenito até $440 \mathrm{mg} \mathrm{kg}^{-1}$ em latossolos provenientes de basalto.

As médias originais e o teste de Tukey para os teores de $\mathrm{Cr}, \mathrm{Cu}^{2+}, \mathrm{Mn}^{2+}, \mathrm{Ni}^{2+} \mathrm{e}$ $\mathrm{Zn}^{2+}$ em função dos métodos de extração dentro de cada tratamento são apresentados na Tabela 25 .

Na determinação dos teores solúveis de Cr do tratamento LV+lodo (Tabela 25), os métodos $\mathrm{HCl} 0,1 \mathrm{~mol} \mathrm{~L}^{-1}$ e Mehlich 3 se equivaleram. Discordando de Bertoncini

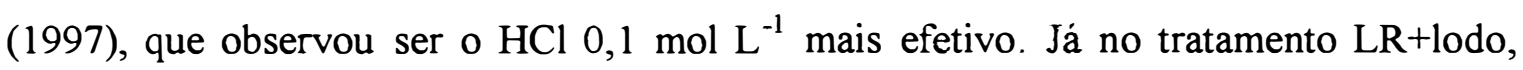
somente o Mehlich 3 foi efetivo na extração de $\mathrm{Cr}$.

$\mathrm{Na}$ extração dos teores solúveis de $\mathrm{Cu}^{2+}$ (Tabela 25) verificou-se que nos tratamentos $\mathrm{LV}+$ lodo, $\mathrm{LV}$, e LR as soluções de $\mathrm{HCl} \mathrm{0,1} \mathrm{mol} \mathrm{L}^{-1}$ e Mehlich 3 removeram igualmente maiores teores de $\mathrm{Cu}^{2+}$. Todavia, no tratamento LR+lodo, o Mehlich 3 foi o que extraiu os maiores teores de $\mathrm{Cu}^{2+}$. Este comportamento discorda das observações realizadas por Oliveira (1995) e Bertoncini (1997). Oliveira (1995) verificou que em todos os tratamentos as quantidades de $\mathrm{Cu}^{2+}$ removidas pelos extratores $\mathrm{HCl} 0,1$ mol L ${ }^{-1}$ e DTPA pH 7,3 eram semelhantes tanto no solo AQ quanto no solo LR, nas duas épocas de amostragem (aos 63 e 118 dias de incubação do biossólido). De acordo com Bertoncini (1997), o Mehlich 3 foi o extrator mais eficiente na remoção de $\mathrm{Cu}^{2+}$ no tratamento LV+lodo.

Nos tratamentos com biossólido (Tabela 25), os extratores $\mathrm{HCl} \mathrm{0,1} \mathrm{mol} \mathrm{L}{ }^{-1} \mathrm{e}$ Mehlich 3 removeram os maiores teores solúveis de $\mathrm{Mn}^{2+}$, sendo que no $\mathrm{LV}+$ lodo estes teores chegaram a se equivaler ao teor total determinado pela ágıa régia. Isto indica que tais extratores por serem soluções ácidas conseguiram solubilizar o Mn que estava insolúvel nestes tratamentos devido ao $\mathrm{pH}$ elevado das amostras de terra, propiciado pela adição do biossólido. Segundo Borkert (1991) tem sido observado que as soluções 
ácidas extraem mais $\mathrm{Mn}^{2+}$ do que as outras (alcalinas, sais, complexos orgânicos), isto porque, talvez, estas soluções extraiam formas mais facilmente reduzíveis no solo, além do $\mathrm{Mn}^{2+}$ trocável.

Tabela 25. Teores médios ${ }^{(1)}$ de $\mathrm{Cr}, \mathrm{Cu}^{2+}, \mathrm{Mn}^{2+}, \mathrm{Ni}^{2+}$ e $\mathrm{Zn}^{2+}$ extraídos por soluções de $\mathrm{HCl}$ 0,1 mol L-1, Mehlich 3, DTPA pH 7,3 e água régia observados dentro de cada tratamento.

\begin{tabular}{|c|c|c|c|c|}
\hline Métodos & LV+lodo & $\mathrm{LV}$ & LR+lodo & LR \\
\hline $\mathrm{Cr}$ adicionado $\left(\mathrm{mg} \mathrm{kg}^{-1}\right)$ & 75,06 & - & 88,83 & - \\
\hline $\mathrm{HCl} 0,1 \mathrm{~mol} \mathrm{~L}^{-1}$ & $7,19 \mathrm{~b}$ & nd & nd & nd \\
\hline Mehlich 3 & $2,60 \mathrm{~b}$ & nd & $2,02 \mathrm{~b}$ & nd \\
\hline DTPA pH 7,3 & nd & nd & nd & nd \\
\hline Água régia & $56,90 \mathrm{a}$ & 5.74 & $181,47 \mathrm{a}$ & 28,97 \\
\hline $\mathrm{Cu}$ adicionado $\left(\mathrm{mg} \mathrm{kg}^{-1}\right)$ & $\overline{114,64}$ & - & 135,68 & - \\
\hline $\mathrm{HCl} 0,1 \mathrm{~mol} \mathrm{~L}^{-1}$ & $18,46 \mathrm{~b}$ & $0,70 \mathrm{~b}$ & $1,19 \mathrm{~d}$ & $3,06 \mathrm{~b}$ \\
\hline Mehlich 3 & $19,50 \mathrm{~b}$ & $0,68 \mathrm{~b}$ & $33,22 \mathrm{~b}$ & $3,20 \mathrm{~b}$ \\
\hline DTPA pH 7,3 & $12,90 \mathrm{c}$ & $0,33 \mathrm{c}$ & $23,40 \mathrm{c}$ & $2,14 \mathrm{c}$ \\
\hline Água régia & $54,66 \mathrm{a}$ & $2,10 \mathrm{a}$ & $131,29 \mathrm{a}$ & $32,46 \mathrm{a}$ \\
\hline Mn adicionado ( $\left.\mathrm{mg} \mathrm{kg}^{-1}\right)$ & 51,46 & & 60,90 & \\
\hline $\mathrm{HCl} 0,1 \mathrm{~mol} \mathrm{~L}^{-1}$ & $27,61 \mathrm{ab}$ & $7,46 \mathrm{ab}$ & $40,54 \mathrm{~b}$ & $108,46 \mathrm{~b}$ \\
\hline Mehlich 3 & $16,28 b$ & $5,10 \mathrm{~b}$ & $49,97 \mathrm{~b}$ & $73,82 b c$ \\
\hline DTPA pH 7,3 & $1,78 \mathrm{c}$ & $1,55 \mathrm{~b}$ & $14,72 \mathrm{c}$ & $62,44 \mathrm{c}$ \\
\hline Água régia & $51.16 \mathrm{a}$ & $25.97 \mathrm{a}$ & $417,60 \mathrm{a}$ & $597,24 \mathrm{a}$ \\
\hline $\mathrm{Ni}$ adicionado $\left(\mathrm{mg} \mathrm{kg}^{-1}\right)$ & 54,50 & - & 64,50 & - \\
\hline $\mathrm{HCl} 0,1 \mathrm{~mol} \mathrm{~L}^{-1}$ & $16.25 \mathrm{~b}$ & nd & $3,70 \mathrm{c}$ & nd \\
\hline Mehlich 3 & $11,05 \mathrm{c}$ & nd & $10,60 \mathrm{~b}$ & nd \\
\hline DTPA pH 7,3 & $2,47 \mathrm{~d}$ & nd & $5,46 \mathrm{c}$ & nd \\
\hline Água régia & $31,95 \mathrm{a}$ & nd & $53.91 \mathrm{a}$ & nd \\
\hline $\mathrm{Zn}$ adicionado $\left(\mathrm{mg} \mathrm{kg}^{-1}\right)$ & 296,32 & - & 350,69 & - \\
\hline $\mathrm{HCl} 0,1 \mathrm{~mol} \mathrm{~L}^{-1}$ & $110,22 \mathrm{~b}$ & $1,95 \mathrm{~b}$ & $24,22 \mathrm{~d}$ & $3,05 \mathrm{~b}$ \\
\hline Mehlich 3 & $58,88 \mathrm{c}$ & $1,60 \mathrm{~b}$ & $78,57 \mathrm{~b}$ & $2,35 \mathrm{~b}$ \\
\hline DTPA pH 7,3 & $23,52 \mathrm{~d}$ & $1,18 \mathrm{~b}$ & $49,30 \mathrm{c}$ & $1,32 \mathrm{~b}$ \\
\hline Água régia & $142,51 \mathrm{a}$ & $5,74 \mathrm{a}$ & $303,02 \mathrm{a}$ & $29,22 \mathrm{a}$ \\
\hline
\end{tabular}

$\pi$ Médias seguidas da mesma letra na vertical não diferem estatisticamente entre si ao nível de $5 \%$ de significância pelo teste de Tukey.

nd = Não determinado, teores abaixo do limite de detecção do método analítico empregado. 
No tratamento testemunha LV (Tabela 25), os extratores $\mathrm{HCl} \mathrm{0,1} \mathrm{mol} \mathrm{L}^{-1}$, Mehlich 3 e DTPA pH 7,3 removeram igualmente os maiores teores solúveis de $\mathrm{Mn}^{2+}$, sendo comparáveis ao teor total obtido pela água régia. Entretanto, no tratamento testemunha LR os maiores teores solúveis de $\mathrm{Mn}^{2+}$ foram obtidos igualmente com extratores $\mathrm{HCl} 0,1 \mathrm{~mol} \mathrm{~L}^{-1}$, Mehlich 3 e DTPA pH 7,3, porém não se equivaleram aos teores obtidos com a água régia. Este comportamento deve-se provavelmente a ocorrência natural de maiores teores de $\mathrm{Mn}^{2+}$ nas amostras de terra LR, do que nas LV.

No que se refere a extração de $\mathrm{Ni}^{2+}$ (Tabela 25), constatou-se que no tratamento $\mathrm{LV}+$ lodo, a solução $\mathrm{HCl} 0,1 \mathrm{~mol} \mathrm{~L}^{-1}$ removeu os maiores teores solúveis de $\mathrm{Ni}^{2+}$. Fato idêntico ao observado por Bertoncini (1997). Entretanto, no tratamento LR+lodo foi o extrator Mehlich 3 que removeu os maiores teores solúveis de $\mathrm{Ni}^{2+}$.

Com relação a extração de $\mathrm{Zn}^{2+}$ (Tabela 25), observou-se que nos tratamentos testemunha os métodos $\mathrm{HCl} 0,1 \mathrm{~mol} \mathrm{~L}^{-1}$, Mehlich 3 e DTPA pH 7,3 extraíram igualmente os maiores teores de $\mathrm{Zn}^{2+}$ solúvel, enquanto que no tratamento $\mathrm{LV}+$ lodo os

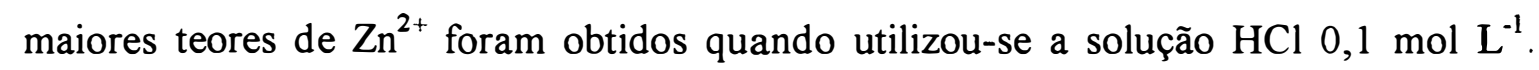
Comportamento este idêntico ao observado por Bertoncini (1997). Entretanto, no tratamento LR+lodo (Tabela 25) a extração foi maior quando utilizou-se a solução Mehlich 3.

Deste modo, nas amostras de terra LV tratadas com biossólido (Tabela 25), o extrator $\mathrm{HCl} 0,1 \mathrm{~mol} \mathrm{~L}^{-1}$ foi mais eficiente que os extratores Mehlich 3 e DTPA pH 7,3 na remoção dos teores solúveis de $\mathrm{Ni}^{2+}$ e $\mathrm{Zn}^{2+}$, recuperando respectivamente 30 e $37 \%$

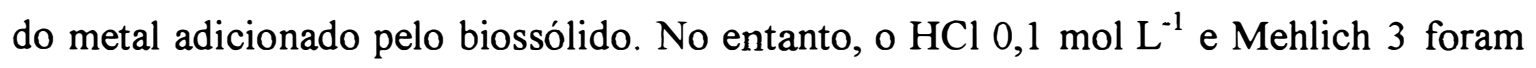
igualmente mais eficientes na extração dos teores solúveis de $\mathrm{Cr}, \mathrm{Cu}^{2+}$ e $\mathrm{Mn}^{2+}$, recuperando, respectivamente, em média 6,16 e $30 \%$ do metal adicionado pelo biossólido. No caso dos teores solúveis de $\mathrm{Mn}^{2+}$, cabe ressaltar que estes teores se equipararam aos teores totais obtidos com a água régia.

Nas amostras de terra LR tratadas com biossólido (Tabela 25), o extrator Mehlich 3 foi o mais eficiente na remoção dos teores solúveis de $\mathrm{Cr}, \mathrm{Cu}^{2+}, \mathrm{Ni}^{2+}$ e $\mathrm{Zn}^{2+}$, recuperando respectivamente $2,22,16$ e $22 \%$ do metal adicionado pelo biossólido. Ao passo que as soluções $\mathrm{HCl} 0,1 \mathrm{~mol} \mathrm{~L}^{-1}$ e Mehlich 3 extraíram igualmente maiores os 
teores solúveis de $\mathrm{Mn}^{2+}$, entretanto não houve recuperação por parte destes extratores da quantidade de $\mathrm{Mn}^{2+}$ adicionada via biossólido, uma vez que os teores obtidos por estes extratores foram muito inferiores aos da testemunha. Conforme comentado anteriormente, tal comportamento pode estar relacionado a elevação do $\mathrm{pH}$ do solo que foi proporcionada pela adição do biossólido.

A remoção de $\mathrm{Cr}$, nos tratamentos $\mathrm{LV}+$ lodo e $\mathrm{LR}+$ lodo, ficaram muito aquém das quantidades adicionadas. Este comportamento também foi verificado por Oliveira (1995).

Com relação as testemunhas (Tabela 25), tanto nas amostras de terra LV quanto nas $\mathrm{LR}$, os extratores $\mathrm{HCl} 0,1 \mathrm{~mol} \mathrm{~L}^{-1}$ e Mehlich 3 foram igualmente mais eficientes na remoção dos teores solúveis de $\mathrm{Cu}^{2+}$. Quanto a extração dos teores solúveis de $\mathrm{Zn}^{2+}$ e $\mathrm{Mn}^{2+}$, todos os extratores utilizados foram eficientes na remoção de $\mathrm{Zn}^{2+}$ e $\mathrm{Mn}^{2+}$ das amostras de terra LV e LR. Com exceção dos teores solúveis de $\mathrm{Mn}^{2+}$ observados no tratamento $\mathrm{LV}$, que chegaram a se equiparar com o teor total.

De maneira geral, em todos os tratamentos constatou-se que a água régia extraiu os maiores teores de metais (Tabela 25). No entanto, estes teores não corresponderam a uma recuperação de $100 \%$.

Nos tratamentos $\mathrm{LR}+$ lodo houve uma recuperação de $73 \%$ para o $\mathrm{Cu}^{2+}, 84 \%$ para o $\mathrm{Ni}^{2+}$ e $78 \%$ para o $\mathrm{Zn}^{2+}$, enquanto que nos tratamentos $\mathrm{LV}+$ lodo ocorreu uma menor recuperação destes metais, sendo de $46 \%$ para o $\mathrm{Cu}^{2+}$ e $\mathrm{Zn}^{2+}$ e de $59 \%$ para o $\mathrm{Ni}^{2+}$. De acordo com Keller \& Védy (1994), a água régia extrai todos os metais presentes na fração residual do solo, exceto àqueles que ocorrem nos silicatos, deste modo a percentagem de extração varia de $60-100 \%$, dependendo do metal. Além desta observação, tem-se que levar em consideração que a quantidade de terra utilizada na análise é muito pequena considerando a heterogeneidade do material.

Comparando a recuperação de $\mathrm{Cr}, \mathrm{Cu}^{2+}, \mathrm{Ni}^{2+}$ e $\mathrm{Zn}^{2+}$ realizada pela água régia neste experimento com a recuperação obtida por Abreu et al. (1996), observa-se que as quantidades de metais recuperadas foram de maneira geral inferiores as obtidas por Abreu et al. (1996). Entretanto, esses autores submeteram os resíduos, dentre eles o biossólido, diretamente a extração com água régia, enquanto que no presente trabalho o 
biossólido foi aplicado em amostras de terras distintas. Assim, a recuperação realizada pela água régia recebeu a influência das amostras de terra, conforme foi detectado pela significância do teste $F$ (Apêndices 3.3 e 3.4).

A menor recuperação de metais verificada no tratamento $\mathrm{LV}+$ lodo pode estar relacionada também a menor capacidade de adsorção, a textura média desta amostra de terra (Tabela 5) e a formação de complexos organo-metálico solúveis, pois os metais $\mathrm{Cu}^{2+}, \mathrm{Ni}^{2+} \mathrm{e} \mathrm{Zn}^{2+}$ podem ter sido mobilizados para profundidades superiores a $20 \mathrm{~cm}, \mathrm{em}$ função da formação de complexos com ligantes orgânicos solúveis, oriundos da oxidação da matéria orgânica do biossólido, escapando desta forma do raio de amostragem. Estas observações estão de acordo com estudos de Lund et al. (1976), Wech \& Lund (1987), Reddy et al. (1995), Camobreco et al. (1996) e Bertoncini (1997).

Com relação a recuperação do $\mathrm{Cr}$, observou-se que no tratamento $\mathrm{LR}+$ lodo ocorreu uma recuperação que ultrapassou a quantidade adicionada via biossólido, sendo de $172 \%$, enquanto que no tratamento $\mathrm{LV}+$ lodo esta recuperação foi de $67 \%$. Este fato pode estar relacionado a ocorrência natural de maiores teores deste metal no LR.

Quanto ao $\mathrm{Mn}^{2+}$, constatou-se que no tratamento $\mathrm{LR}+$ lodo a água régia recuperou o $\mathrm{Mn}^{2+}$ adicionado e parte do $\mathrm{Mn}^{2+}$ já existente no próprio solo, porém em quantidade inferior a testemunha (Tabela 25), o que resultou em uma recuperação de $-295 \%$. No tratamento $\mathrm{LV}+$ lodo a recuperação do $\mathrm{Mn}^{2+}$ foi de $49 \%$. Este comportamento pode estar relacionado a elevação do $\mathrm{pH}$ do solo a valor próximo de 7,0 devido a adição do biossólido, favorecendo desta maneira a atividade dos microrganismos que oxidam o $\mathrm{Mn}^{2+}$ solúvel a formas indisponíveis. Isto foi mais evidente nas amostras de terra LR, por serem naturalmente mais férteis que as LV (Tabela 4).

O teor total de $\mathrm{Cd}^{2+}$ apresentou comportamento totalmente diferente dos demais elementos. Nos tratamentos que receberam biossólido (Figura 24), a água régia conseguiu remover $4,1 \mathrm{mg} \mathrm{kg}^{-1} \mathrm{de} \mathrm{Cd}$, entretanto tal teor foi menor que o encontrado nas testemunhas LV e LR, sendo respectivamente de 4,7 e $6,5 \mathrm{mg} \mathrm{kg}^{-1}$. Assim, não se pode afirmar que a adição de $388 \mathrm{Mg} \mathrm{ha}^{-1}$ de biossólido, base seca, que incorporou em média $3,41 \mathrm{mg} \mathrm{kg}^{-1}$ de $\mathrm{Cd}^{2+}$, tenha contribuindo para a elevação do teor total de $\mathrm{Cd}^{2+}$ até a 
profundidade de $20 \mathrm{~cm}$ nas amostras de terra LV e LR. Em estudos feitos em laboratório para estimar as interações entre $\mathrm{Cd}^{2+}$, matéria orgânica solúvel do biossólido e solo, Lamy et al. (1993) observaram que ocorreu maior formação de complexos orgânicos solúveis com $\mathrm{Cd}^{2+}$ na faixa de $\mathrm{pH}$ de 5 a 7 . Desta forma, em solos ácidos ou naqueles em que o $\mathrm{pH}$ é mantido próximo a neutralidade $(6,5-7,0)$ a aplicação de biossólidos seria limitada, devido a mobilidade de $\mathrm{Cd}$ que poderia atingir o lençol freático.

Ao se comparar os teores totais de $\mathrm{Cr}, \mathrm{Cu}^{2+}, \mathrm{Ni}^{2+}$ e $\mathrm{Zn}^{2+}$ extraídos pela água régia (Tabela 25) com os limites críticos estabelecidos pela USEPA e pela Diretriz da Comunidade Européia (Tabela 3), verificou-se que tais teores estão dentro do limite de padrão de qualidade do solo, apesar das sucessivas aplicações de biossólido, que totalizaram a adição de $388 \mathrm{Mg} \mathrm{ha}^{-1}$, base seca.

No entanto, observou-se que o teor total de $4,1 \mathrm{mg} \mathrm{kg}^{-1}$ de $\mathrm{Cd}^{2+}$ extraído pela água régia está dentro do limite de padrão de qualidade do solo, se for considerado o nível crítico de $\mathrm{Cd}^{2+}$ no solo de $20 \mathrm{mg} \mathrm{kg}^{-1}$ de matéria seca estabelecido pela USEPA (Hall, 1998). Todavia, se for considerado o nível crítico de $1-3 \mathrm{mg} \mathrm{kg}^{-1}$ de matéria seca estabelecido pela Diretriz da Comunidade Européia (Hall, 1998) verificar-se-á que os tratamentos que receberam biossólido, bem como as amostras de terra das testemunhas não se encontram dentro do padrão de qualidade de solo. A se considerar esta Diretriz para solos de condições tropicais, em função do material de origem, ter-se-á valores que caracterizam solos de áreas que não receberam adições antropomórficas como solos contaminados. Deste modo, faz-se necessário o estabelecimento de critérios para condições de solos sob clima tropical.

\subsubsection{Avaliação dos metais na planta de milho}

Este capitulo aborda os teores e quantidades absorvidas de metais nas diversas partes da planta de milho, sendo apresentados na forma de gráficos. Entretanto, para maiores informações estes dados também encontram-se na forma de tabelas, respectivamente, nos apêndices 4.1 e 4.2. Os resultados relativos à produção de matéria 
seca serão apresentados no capítulo 4.3.

Os resultados referentes aos metais $\mathrm{Cd}, \mathrm{Ni}$ e $\mathrm{Pb}$ nas diversas partes do milho e aos teores e quantidades absorvidas de $\mathrm{Cr}$ na bainha, no colmo, na FD (folha diagnose), na FF (folhas ao final do ciclo da cultura), no grão e na palha não serão apresentados, pois estiveram abaixo do limite de deteç̧ão (nd) do método analítico empregado, apesar da elevada quantidade de biossólido utilizada no experimento.

\subsubsection{Crômio}

$\mathrm{O}$ teste $\mathrm{F}$ (Apêndice 4.3) demonstrou haver diferenças significativas entre os tratamentos das variáveis teor e quantidade absorvida de $\mathrm{Cr}$ encontrados no sabugo das plantas de milho, ao nível de $1 \%$ e $5 \%$, respectivamente.

Pela técnica dos contrates ortogonais (Apêndice 4.5), encontrou-se apenas, tanto para a variável teor quanto para a variável quantidade absorvida de $\mathrm{Cr}$, diferenças entre os tratamentos testemunha, sendo comprovadas estatisticamente pelo teste $\mathrm{F}$ ao nível de $1 \%$ e $5 \%$, respectivamente, o que indica a existência de diferenças na ocorrência natural do elemento nos solos. Na Figura 27 observa-se que as plantas de milho que se desenvolveram no tratamento LR apresentaram os maiores teores médios e quantidades médias absorvidas de $\mathrm{Cr}$ no sabugo (1,85 $\mathrm{mg} \mathrm{kg}^{-1}$ e $0,04 \mathrm{mg}$ vaso ${ }^{-1}$, respectivamente).

A não constatação no presente trabalho do aumento da fitodisponibilidade de $\mathrm{Cr}$ com a aplicação de biossólido diverge do que foi observado por André et al. (1994) em sorgo granifero, Oliveira (1995) e Pierrisnard (1996), ao trabalharem ambos com milho. Após aplicar 0, 22, 45 e $90 \mathrm{Mg} \mathrm{ha}^{-1}$ de biossólido, base seca, em um solo franco siltoso e cultivar milho, Ritter \& Eastburn (1978) constataram concentrações normais de $\mathrm{Cr}$ nos grãos de milho e nos colmos $\left(<1,0 \mathrm{mg} \mathrm{kg}^{-1}\right.$ de $\mathrm{Cr}$ no grão e de $<1,0-2,0 \mathrm{mg} \mathrm{kg}^{-1} \mathrm{de} \mathrm{Cr}$ nos colmos). Após três aplicações anuais de biossólido em um solo franco siltoso, que totalizou aplicações acumuladas de 0,60,120 e $180 \mathrm{Mg} \mathrm{ha}^{-1}$ de biossólido, base seca, Bidwell \& Dowdy (1987) observaram que as concentrações de $\mathrm{Cr}$ nos colmos e grãos oscilaram anualmente, não sendo preditas pelo efeito das doses de biossólido. 
(a)

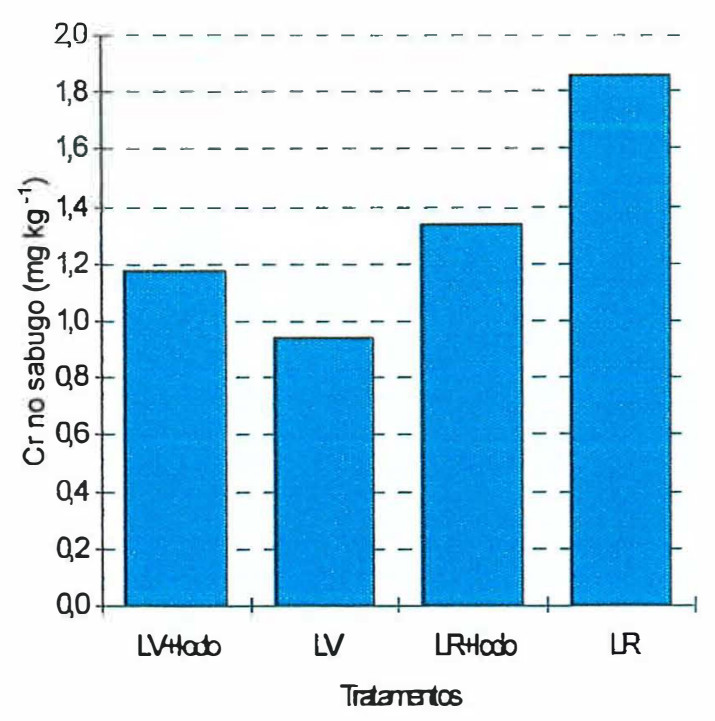

(b)

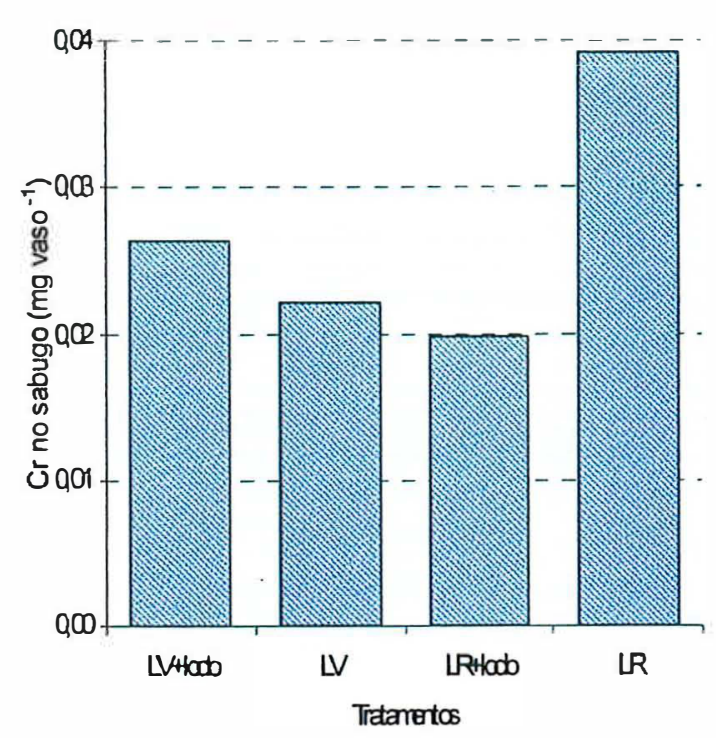

Figura 27 - Variações no teor (a) e na quantidade absorvida (b) de $\mathrm{Cr}$ encontrados no sabugo das plantas de milho em função das aplicações de biossólido.

\subsubsection{Cobre}

Analisando esta variável, observa-se que ocorreram diferenças significativas entre os tratamentos no que diz respeito aos teores deste elemento nas diversas partes da planta, bem como em suas respectivas quantidades absorvidas, sendo comprovado estatisticamente pela significância do teste $\mathrm{F}$ ao nível de 1\% (Apêndice 4.3). Com exceção do teor e quantidade absorvida de $\mathrm{Cu}$ no grão que foram significativos ao nível de $5 \%$ e da quantidade absorvida de $\mathrm{Cu}$ no sabugo que não apresentou diferença significativa.

As plantas que se desenvolveram no tratamento com biossólido, independentemente do tipo de solo, apresentaram maiores teores médios e quantidades absorvidas de $\mathrm{Cu}$ na bainha, colmo, palha, $\mathrm{FD}$ e FF que as plantas desenvolvidas nos tratamentos testemunha (Apêndice 4.5 e Figura 28). Além disso, as plantas do tratamento com biossólido também apresentaram maiores teores médios de $\mathrm{Cu}$ nos grãos 
e sabugo.

Devido a grandeza de unidades ocorrentes nas diversas partes da planta, não é possível visualizar as quantidades médias absorvidas de $\mathrm{Cu}$ presentes na palha, entretanto foram no $\mathrm{LV}+$ lodo e $\mathrm{LR}+$ lodo $=0,006 \mathrm{mg} \mathrm{vaso}^{-1}, \mathrm{LV}=0,002 \mathrm{mg} \mathrm{vaso}^{-1} \mathrm{e}$ $\mathrm{LR}=0,003 \mathrm{mg} \mathrm{vaso}^{-1}$.

As altas quantidades $\mathrm{Cu}$ adicionadas via biossólido $\left(114,64 \mathrm{mg} \mathrm{kg}^{-1}\right.$ de terra no LV e 135,64 $\mathrm{mg} \mathrm{kg}^{-1}$ de terra no LR) contribuíram para aumentar os teores de Cu nas diversas partes da planta de milho. Tal comportamento também foi constatado por Ritter \& Eastburn (1978), Reddy et al. (1989), Al-Jaloud et al. (1995), Oliveira (1995), Pierrisnard (1996) e Logan et al. (1997), o que evidencia a fitodisponibilidade do elemento aplicado via biossólido.

(a)

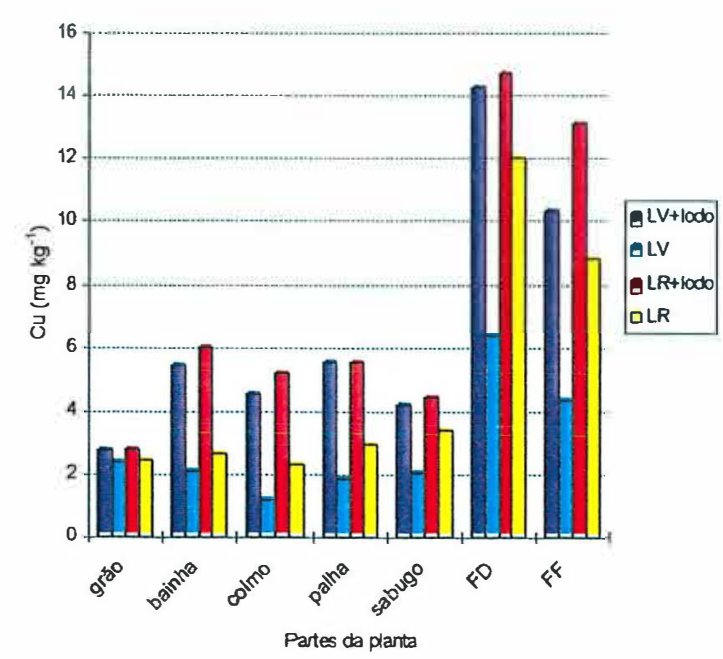

(b)

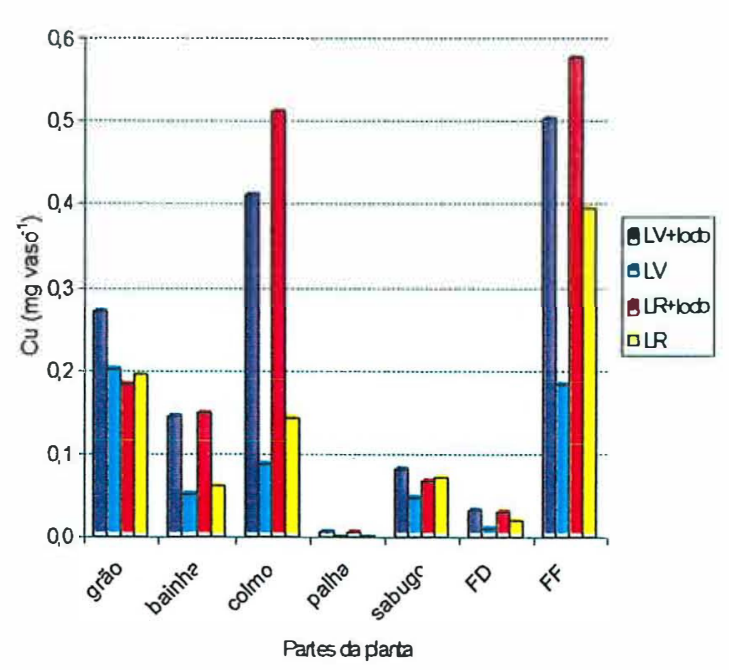

Figura 28 - Variações no teor (a) e na quantidade absorvida (b) de $\mathrm{Cu}$ encontrados nas diversas partes das plantas de milho em função das aplicações de biossólido.

Os teores médios de $\mathrm{Cu}$ encontrados na folha diagnose (FD) das plantas de milho desenvolvidas nos tratamentos com e sem biossólido (Figura 28a) encontram-se dentro 
do intervalo considerado adequado de $6-20 \mathrm{mg} \mathrm{kg}^{-1}$, relatado por Malavolta et al. (1989) e Raij \& Camargo (1996).

No presente trabalho foi encontrado nos tratamentos com biossólido, aproximadamente, $3 \mathrm{mg} \mathrm{kg}^{-1}$ de $\mathrm{Cu}$ nos grãos e $5 \mathrm{mg} \mathrm{kg}^{-1}$ de $\mathrm{Cu}$ nos colmos da planta de milho. Estes resultados estão próximos aos obtidos por Reddy et al. (1989), respectivamente, 2 e $7 \mathrm{mg} \mathrm{kg}^{-1}$, ao aplicar $200 \mathrm{Mg} \mathrm{ha}^{-1}$ de biossólido, base seca, em um solo franco arenoso. Conforme os autores, as concentrações de $\mathrm{Cu}$ nos grãos de milho encontravam-se dentro da faixa considerada normal para a cultura. Rappaport et al. (1988) também comentam que, ao aplicar doses crescentes de biossólido (0 à 210 $\mathrm{Mg} \mathrm{ha}^{-1}$, base seca), em três solos de texturas distintas, as concentrações de $\mathrm{Cu}$ nos grãos de milho e nas folhas da base da espiga, folhas diagnose, de todos os tratamentos (em média, respectivamente, 5 e $8 \mathrm{mg} \mathrm{kg}^{-1}$ na dose de $210 \mathrm{Mg} \mathrm{ha}^{-1}$ ), nos três solos, mantiveram-se dentro da faixa considerada a dequada.

Analisando apenas os tratamentos com biossólido (Apêndice 4.5 e Figura 28a), verifica-se que não ocorreu diferença significativa no teor médio de $\mathrm{Cu}$ encontrado nas diversas partes da planta de milho, com exceção das folhas ao final do ciclo da cultura (FF). Nesta parte da planta, os maiores teores médios $\mathrm{Cu}$ foram encontrados nas plantas desenvolvidas no LR. Todavia, as quantidades absorvidas de $\mathrm{Cu}$ no colmo e FF (Apêndice 4.5 e Figura 28b), foram maiores nas plantas desenvolvidas no LR, enquanto que as encontradas no grão foram maiores nas desenvolvidas no LV.

Nos tratamentos testemunha (Apêndice 4.5 e Figura 28a), observou-se que os teores médios de $\mathrm{Cu}$ em todas as partes da planta, com exceção dos grãos, foram maiores nas desenvolvidas no LR. As quantidades de $\mathrm{Cu}$ também apresentaram o mesmo comportamento, exceto as quantidades de $\mathrm{Cu}$ na bainha e sabugo, que não se diferenciaram significativamente. Isso deve-se ao fato do LR apresentar originalmente maior teor deste elemento $\left(2,1 \mathrm{mg} \mathrm{dm}^{-3}\right.$ de terra) do que o $\mathrm{LV}\left(0,3 \mathrm{mg} \mathrm{dm}^{-3}\right.$ de terra). De acordo com Marschner (1995), o Cu é classificado, em função de sua mobilidade no floema, como um elemento de mobilidade intermediária, o que pode explicar a semelhante concentração encontrada nos grãos nos tratamentos LV e LR.

Com relação as plantas desenvolvidas nos tratamentos que não receberam 
biossólido, observou-se (Apêndice 4.5 e Figura 28b) o mesmo comportamento apresentado pelos teores médios de $\mathrm{Cu}$ em todas as partes da planta. Com exceção das quantidades absorvidas de $\mathrm{Cu}$ encontradas na bainha e sabugo que não se diferenciaram significativamente. Nas demais partes da planta (colmo, palha, FD e FF) as maiores quantidades absorvidas de $\mathrm{Cu}$ foram encontradas nas plantas que se desenvolveram no LR.

Quanto a ocorrência desse metal no milho, verificou-se que, tanto na testemunha como nos tratamentos com biossólido, os maiores teores de $\mathrm{Cu}$ foram encontrados nas folhas (Figura 28a), incluindo folha diagnose (FD) e folha ao final do ciclo da cultura (FF). As maiores quantidades absorvidas de $\mathrm{Cu}$ foram encontradas nas folhas ao final do ciclo da cultura, seguidas pelos colmos e grãos (Figura 28b). Estes dados sugerem que o $\mathrm{Cu}$ tende a se acumular nas folhas do milho.

\subsubsection{Manganês}

Os teores e as quantidades absorvidas de Mn encontrados na bainha, colmo, FD, FF e palha foram influenciados pelos tratamentos, sendo comprovados pela significância do teste $\mathrm{F}$ ao nível de 1\% (Apêndices 4.3 e 4.4). Também o teor de Mn encontrado no sabugo foi influenciado pelos tratamentos, sendo comprovado entretanto pela significância do teste $\mathrm{F}$ ao nível de 5\% (Apêndice 4.4). Quanto aos teores e quantidades absorvidas de Mn encontrados nos grão, não constatou-se diferença significativa entre os tratamentos, bem como para as quantidades absorvidas encontradas no sabugo (Apêndice 4.4).

Comparando-se as médias dos tratamentos das plantas que receberam aplicação de biossólido com as que não receberam (Apêndice 4.5 e Figura 29), constata-se que os teores e quantidades absorvidas de Mn encontrados na bainha e no colmo das plantas de milho que receberam aplicação de biossólido foram menores, enquanto que as quantidades absorvidas de Mn encontradas na FD foram maiores.

A adição de biossólido no solo diminuiu o teor de Mn extraído em DTPA, das 
amostras de terra, conforme discutido anteriormente, porém constata-se que este efeito não foi verificado no teor foliar. Fato semelhante foi observado por Silva (1995), ao trabalhar com cana de açúcar.

Na Figura 29b não é possível visualizar as quantidades absorvidas de $\mathrm{Mn}$ encontradas na FD, devido a unidade de grandeza ocorrente nas outras partes da planta, entretanto os valores médios encontrados nos tratamentos foram $\mathrm{LV}+$ lodo $=0,05 \mathrm{mg}$ vaso $^{-1}, \mathrm{LR}+$ lodo $=0,13 \mathrm{mg} \mathrm{vaso}^{-1}, \mathrm{LV}=0,04 \mathrm{mg} \mathrm{vaso}^{-1} \mathrm{e} \mathrm{LR}=0,08 \mathrm{mg}$ vaso $^{-1}$.

(a)

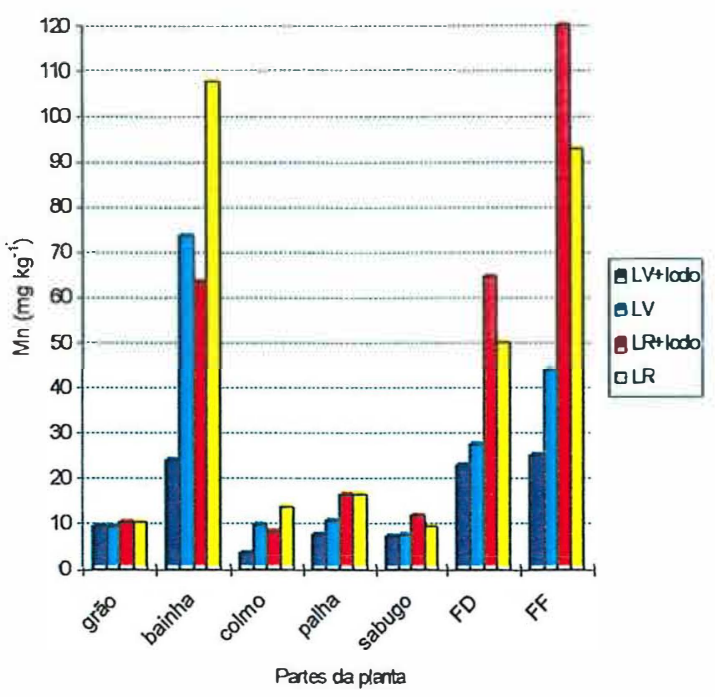

(b)

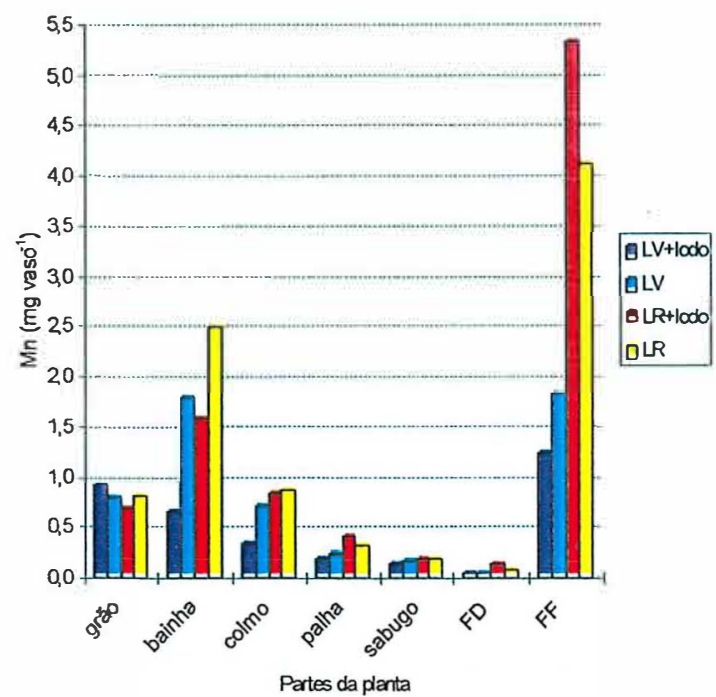

Figura 29 -- Variações no teor (a) e na quantidade absorvida (b) de Mn encontrados nas diversas partes das plantas de milho em função das aplicações de biossólido.

Analisando-se apenas as plantas que receberam biossólido, observa-se nos Apêndices 4.5 e 4.6 e na Figura 29 que as plantas desenvolvidas no LR apresentaram maiores teores e quantidades absorvidas de $\mathrm{Mn}$ na bainha, colmo, FD, FF e palha do que as desenvolvidas no LV. Este mesmo comportamento foi verificado na quantidade absorvida de Mn encontrada no sabugo.

Entre as plantas que não receberam biossólido também constatou-se (Apêndices 
4.5 e 4.6 e Figura 29) que as desenvolvidas no LR apresentaram maiores teores e quantidades absorvidas de $\mathrm{Mn}$ na bainha, FD e FF. Na palha e no colmo verificou-se apenas que os teores de $\mathrm{Mn}$ foram mais elevados nas plantas desenvolvidas no LR.

Os teores médios de Mn observados na folha diagnose (FD) das plantas de milho (Figura 29a), de todos os tratamentos, encontram-se dentro do intervalo considerado adequado de 20-200 $\mathrm{mg} \mathrm{kg}^{-1}$, relatado por Raij \& Camargo (1996).

Com relação a preferência de ocorrência desse metal no milho, constatou-se que, tanto na testemunha como nos tratamentos que receberam biossólido, os maiores teores de Mn foram encontrados na folha ao final do ciclo da cultura (FF), seguidos pela bainha e folha diagnose (FD) (Figura 29a), enquanto que as maiores quantidades de Mn foram encontradas nas folhas ao final do ciclo da cultura e bainha (Figura 29b). Assim, o Mn além de tender a se acumular nas folhas, também tende a se acumular na bainha do milho.

\subsubsection{Zinco}

Os teores e as quantidades absorvidas de $\mathrm{Zn}$ encontradas nas diversas parte da planta de milho (grão, bainha, colmo, palha, sabugo, FD e FF) foram influenciados pelos tratamentos, sendo comprovado estatisticamente pela significância do teste $\mathrm{F}$ ao nível de 1\% (Apêndice 4.4).

Comparando-se as médias dos tratamentos das plantas com e sem biossólido (Apêndice 4.6 e Figura 30), verifica-se que os teores e quantidades absorvidas de $\mathrm{Zn}$ encontrados em todas as partes do milho que receberam aplicação de biossólido foram maiores, sendo comprovado estatisticamente pelo teste $\mathrm{F}$ ao nível de $1 \%$, exceto para as quantidades absorvidas de $\mathrm{Zn}$ encontradas no grão que foi ao nível de $5 \%$. Este comportamento evidencia a fitodisponibilidade do elemento adicionado via biossólido.

$\mathrm{O} \mathrm{Zn}$ foi, dentre os metais estudados, o elemento mais absorvido nos tratamentos com biossólido. Assumindo que o aumento da quantidade de $\mathrm{Zn}$ absorvida pelas plantas foi devida a adição de biossólido, pode-se calcular que a quantidade absorvida deste 
elemento representou $0,01 \%$ da adicionada via biossólido, em ambos as amostras de terra estudadas. Este comportamento está de acordo com Chang et al. (1987) que comenta que as quantidades absorvidas de metais pelas plantas, em áreas que recebem biossólidos, são pequenas e geralmente inferiores a $1 \%$ da quantidade originária do resíduo.

(a)

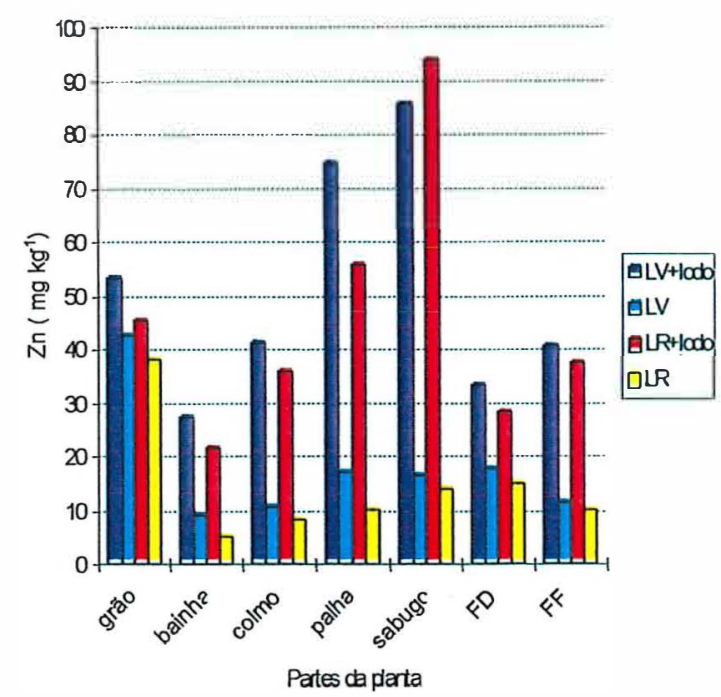

(b)

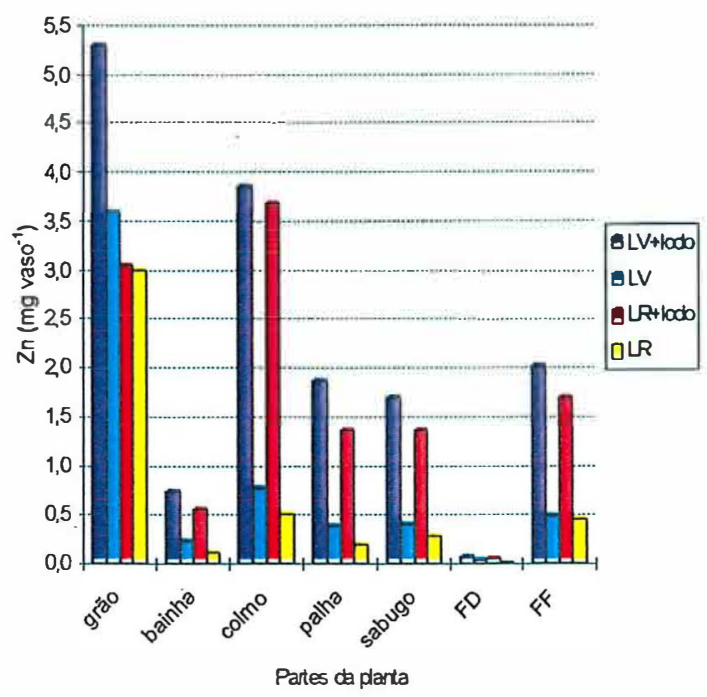

Figura 30 - Variações no teor (a) e na quantidade absorvida (b) de $\mathrm{Zn}$ encontrados nas diversas partes das plantas de milho em função das aplicações de biossólido.

Estudando, durante um período de seis anos, a disponibilidade de $\mathrm{Cd}$ e $\mathrm{Zn}$ para a cultura de milho após o término de três aplicações anuais de biossólidos em um solo franco siltoso, que totalizou aplicações acumuladas de 0,60, 120 e $180 \mathrm{Mg} \mathrm{ha}^{-1}$ de biossólido, base seca, Bidwell \& Dowdy (1987) também observaram que nos tratamentos que receberam biossólido ocorreu um aumento significativo nos teores de $\mathrm{Zn}$ nos colmos e nos grãos. As concentrações de $\mathrm{Zn}$ nos colmos aumentaram linearmente com as aplicações em todos os anos. Reddy et al (1989) também constataram que a concentração de $\mathrm{Zn}$ aumentou nas folhas e colmos da planta de milho 
em função da adição do biossólido. Entretanto, a concentração de $\mathrm{Zn}$ nos grãos não se alterou significativamente com as doses aplicadas. Cabe ressaltar que os autores cultivaram o milho após aplicar, em um solo franco arenoso, doses de 0, 25, 50 e 100 $\mathrm{Mg} \mathrm{ha}^{-1}$ de biossólido, base seca, incorporadas até a profundidade de $25 \mathrm{~cm}$, cultivar soja e novamente aplicar as mesmas doses de biossólido.

Em estudo conduzido por Logan et al. (1997) em um solo franco argiloso, foram aplicadas doses $0,7,5,15,30,60,90,120,150,188,225$ e $300 \mathrm{Mg} \mathrm{ha}^{-1}$ de biossólido, base seca, incorporadas até a profundidade de $15 \mathrm{~cm}$ e cultivadas duas culturas, milho e alface. Os resultados mostraram que nas folhas da base da espiga do milho, folhas diagnose, as concentrações de $\mathrm{Zn}$ aumentaram significativamente com as doses aplicadas.

No presente trabalho, nos tratamentos com biossólido (Apêndice 4.6 e Figura 30) observou-se que os teores médios de $\mathrm{Zn}$ encontrados no grão e na palha, bem como as quantidades presentes no grão e na bainha foram maiores nas plantas que se desenvolveram no LV.

Entre as plantas que não receberam biossólido (Apêndice 4.6 e Figura 30) também constatou-se que as desenvolvidas no LV apresentaram maiores teores e quantidades absorvidas de $\mathrm{Zn}$ na bainha e na palha, assim como maiores quantidades absorvidas de $\mathrm{Zn}$ no colmo.

Essa maior disponibilidade de $\mathrm{Zn}$ verificada no $\mathrm{LV}$, tanto nos tratamentos com quanto sem biossólido, é contrária ao observado para os outros metais estudados, que apresentaram de maneira geral maiores teores e quantidades absorvidas no LR, exceto a quantidade de $\mathrm{Cu}$ no grão. Isso evidencia que o LR apresenta menor disponibilidade de $\mathrm{Zn}$, sendo este comportamento mantido ao se adicionar $\mathrm{Zn}$ via biossólido. Esse fato está relacionado a maior quantidade de CTC, argila e óxidos de Fe e Al ocorrente no LR (Tabela 4 e 5). Muitos autores têm encontrado relações positivas e significativas entre os teores de argila e óxidos e hidróxidos de $\mathrm{Fe}$ e $\mathrm{Al}$ com a adsorção de $\mathrm{Zn}$ (Kalbasi et al., 1978; Pombo \& Klamt, 1986). Segundo Mello et al. (1989) e Raij (1991), este elemento é fortemente retido em solos argilosos.

Os teores médios de $\mathrm{Zn}$ observados na folha diagnose (FD) das plantas de milho 
(Figura 30a), de todos os tratamentos, encontram-se dentro do intervalo considerado adequado de 15-100 $\mathrm{mg} \mathrm{kg}^{-1}$, relatado por Raij \& Camargo (1996). Entretanto, ao se comparar os teores médios de $\mathrm{Zn}$ encontrados na FD das plantas desenvolvidas nos tratamentos com biossólido com os teores de $15-50 \mathrm{mg} \mathrm{kg}^{-1}$, considerados adequados por Malavolta et al. (1989), verifica-se que os teores nas plantas se encontram bem acima dessa faixa. Isto sugere que plantas de milho cultivadas em solos tratados com biossólido, durante vários anos podem apresentar problemas relacionados com a fitotoxicidade desse elemento.

Ritter \& Eastburn (1978), após aplicar 0, 22, 45 e $90 \mathrm{Mg} \mathrm{ha}^{-1}$ de biossólido, base seca, em um solo franco siltoso, constataram que a concentração de $\mathrm{Zn}$ nos tecidos das folhas da base da espiga de milho (FD) eram de $24-43 \mathrm{mg} \mathrm{kg}^{-1}$.

Ao avaliar a disponibilidade de metais em solos tratados com biossólido, Rappaport et al. (1988) verificaram que apesar da aplicação de $\mathrm{Zn}$, via biossólido, exceder o limite estabelecido pelo USEPA, não se observou fitotoxicidade deste elemento à planta de milho, nos diversos solos estudados.

Todavia, ao estudar a fitotoxicidade dos metais pesados em áreas que receberam durante um período de oito anos repetidas aplicações de biossólido (total aplicado durante o período em cada tratamento 0,240, 690 e $870 \mathrm{Mg} \mathrm{ha}^{-1}$, base seca), Berti \& Jacobs (1996) observaram que os rendimentos de todas as culturas, dentre elas o milho foram reduzidas em um ou mais tratamentos com biossólido, devido as concentrações fitotóxicas dos metais, provavelmente $\mathrm{Zn}$ e Ni. Através da extração seqüencial constataram que o $\mathrm{Zn}$ e $\mathrm{Ni}$ encontravam-se nas frações que eram potencialmente disponíveis a absorção pelas plantas (solúvel em água, trocável e solúvel em ácido).

Oliveira (1995) também observou que em todos os tratamentos com as doses de 40,5 $\mathrm{Mg} \mathrm{ha}^{-1}$ de biossólido, base seca, os teores de $\mathrm{Zn}$ nas plantas se apresentavam acima da faixa de $15-50 \mathrm{mg} \mathrm{kg}^{-1}$ e ressaltou futuros problemas com a fitotoxicidade de $\mathrm{Zn}$.

No que se refere a preferência de ocorrência do $\mathrm{Zn}$ nas partes da planta de milho, constatou-se que os maiores teores deste elemento foram encontrados nos grãos das plantas dos tratamentos testemunha. Ao se aplicar biossólido, elevou-se ainda mais os 
teores de $\mathrm{Zn}$ nesse órgão, porém também houve uma elevação muito maior deste elemento no sabugo e palha. De tal forma que a ordem de ocorrência dos teores de $\mathrm{Zn}$ nos tratamentos com biossólido passou a ser: sabugo > palha > grão (Figura 30a).

Com relação as quantidades absorvidas de $\mathrm{Zn}$, estas foram maiores no grão, seguidas pelo colmo, tanto nos tratamentos testemunha quanto nos tratamentos com biossólido (Figura 30b).

\subsubsection{Correlações entre o teores de metais removidos dos solos por diferentes métodos de extração e os observados nas diversas partes da planta}

Com o intuito de determinar para cada elemento estudado o extrator que melhor avalia a fitodisponibilidade foram realizadas, para todos os tratamentos, correlações entre os teores encontrados na matéria seca das diversas partes da planta de milho e os removidos por cada um dos extratores.

Observando a Tabela 26, nota-se que os teores de $\mathrm{Cu}$ encontrados na bainha, colmo, FD, FF, palha foram alta e positivamente correlacionados com os teores extraídos pelas soluções Mehlich 3, DTPA e água régia, bem como os teores de Mn na FF e de $\mathrm{Zn}$ na FF e sabugo, enquanto que os teores de Mn na FD e na palha com os teores extraídos pelo Mehlich 3 e água régia. Já os teores de $\mathrm{Zn}$ na bainha, FD e palha foram alta e positivamente correlacionados com os teores removidos pelos extratores $\mathrm{HCl}$ 0,1 mol L ${ }^{-1}$ e Mehlich 3. Quanto aos teores de $\mathrm{Zn}$ encontrados no colmo e grão, estes apresentaram, respectivamente, alta e moderada correlação positiva com os teores removidos pelos extratores Mehlich 3 e $\mathrm{HCl} 0,1 \mathrm{~mol} \mathrm{~L}^{-1}$.

Tais observações discordam de Rappapot et al. (1988) que ao trabalhar com três solos de classes texturais distintas (areia franca, franco argiloso e franco siltoso) e aplicar doses crescente de biossólido (0-210 $\mathrm{Mg} \mathrm{ha}^{-1}$, base seca, variando cada dose de 42 unidades), não constataram relação significativa entre os teores de $\mathrm{Cu}$ e $\mathrm{Zn}$ extraídos com DTPA e as respectivas concentrações dos metais nas folhas da base da espiga do milho nos três solos estudados. 
Tabela 26. Coeficientes de correlação e respectivas significâncias estatísticas, pelo teste $\mathrm{t}$, entre os teores de $\mathrm{Cr}, \mathrm{Cu}, \mathrm{Mn}$ e $\mathrm{Zn}$ removidos por diversos extratores, teor total e os ocorrentes nas diversas partes da planta.

\begin{tabular}{|c|c|c|c|c|c|c|c|}
\hline Métodos & bainha & colmo & FD & $\mathrm{FF}$ & grão & palha & sabugo \\
\hline & \multicolumn{7}{|c|}{$\mathrm{Cr}$} \\
\hline $\mathrm{HCl}$ & nd & nd & nd & nd & nd & nd & $-0,08$ \\
\hline Mehlich & nd & nd & nd & nd & nd & nd & $-0,09$ \\
\hline DTPA & nd & nd & nd & nd & nd & nd & nd \\
\hline \multirow[t]{2}{*}{ Ag. R. } & nd & nd & nd & nd & nd & nd & 0,02 \\
\hline & \multicolumn{7}{|c|}{$\mathrm{Cu}$} \\
\hline $\mathrm{HCl}$ & $0.40^{* *}$ & $0,26^{*}$ & $0,44^{* *}$ & 0,22 & 0,13 & $0,51^{* *}$ & $0,39 * *$ \\
\hline Mehlich & $0,89 * *$ & $0,74 * *$ & $0,74 * *$ & $0,83^{* *}$ & 0,25 & $0,81^{* *}$ & $0,62 * *$ \\
\hline DTPA & $0,88^{* *}$ & $0,73 * *$ & $0,72 * *$ & $0,84^{* *}$ & $0,26^{*}$ & $0,80^{* *}$ & $0,62^{* *}$ \\
\hline \multirow[t]{2}{*}{ Ag. R. } & $0,80 * *$ & $0,72 * *$ & $0,73^{* *}$ & $0,87^{* *}$ & 0,24 & $0,74^{* *}$ & $0,61 * *$ \\
\hline & \multicolumn{7}{|c|}{$\mathrm{Mn}$} \\
\hline $\mathrm{HCl}$ & $0,56^{* *}$ & $0,56^{* *}$ & $0,46^{* *}$ & $0,48^{* *}$ & 0,17 & $0,59^{* *}$ & $0,26^{*}$ \\
\hline Mehlich & $0,53 * *$ & $0,53 * *$ & $0,70^{* *}$ & $0,79 * *$ & 0,22 & $0,74^{* *}$ & $0,44^{* *}$ \\
\hline DTPA & $0,66 * *$ & $0,66 * *$ & $0,46 * *$ & $0,79 * *$ & 0,16 & $0,64 * *$ & 0,24 \\
\hline \multirow[t]{2}{*}{ Ag. R. } & $0,59 * *$ & $0,52 * *$ & $0,71^{* *}$ & $0,68^{* *}$ & 0,25 & $0,70^{* *}$ & $0,48^{* *}$ \\
\hline & \multicolumn{7}{|c|}{$\mathrm{Zn}$} \\
\hline $\mathrm{HCl}$ & $0,78^{* *}$ & $0,68^{* *}$ & $0,74^{* *}$ & $0,71^{* *}$ & $0,50^{* *}$ & $0,82^{* *}$ & $0,53^{* *}$ \\
\hline Mehlich & $0,79 * *$ & $0,80^{* *}$ & $0,76^{* *}$ & $0,86 * *$ & $0,38 * *$ & $0,83^{* *}$ & $0,84^{* *}$ \\
\hline DTPA & $0.67 * *$ & $0,69^{* *}$ & $0,64^{* *}$ & $0,78^{* *}$ & $0,30^{*}$ & $0,68^{* *}$ & $0,79 * *$ \\
\hline Ag. R. & $0,63 * *$ & $0,68^{* *}$ & $0,60^{* *}$ & $0,72^{* *}$ & $0,27^{*}$ & $0,66^{* *}$ & $0,79 * *$ \\
\hline
\end{tabular}

Ag. $\mathrm{R} .=$ Agua régia: $\mathrm{DTPA}=\mathrm{DTPA} \mathrm{pH} \mathrm{7,3; \textrm {HCl } = \mathrm { HCl } 0 , 1 \mathrm { mol } \mathrm { L }} ;$ Mehlich $=$ Mehlich 3; FD $=$ folha diagnose; $\mathrm{FF}=$ folhas ao final do ciclo da cultura.

nd = Não determinado, abaixo do limite de detecção do método analítico empregado.

* = Significativo ao nivel de $5 \%(\alpha \leq 0,05)$.

** = Significativo ao nível de $1 \%(\alpha \leq 0,01)$.

Todavia, Bidwell \& Dowdy (1987) após o término de três aplicações anuais de biossólido que totalizaram $0,60,120$ e $180 \mathrm{Mg} \mathrm{ha}^{-1}$, base seca, em um solo franco siltoso, constataram que as concentrações de $\mathrm{Zn}$ extraídas do solo pelo DTPA foram altamente correlacionadas com a absorção do milho dentro de quatro dos seis anos de 
avaliação. Contudo, os autores ressaltam que a confiança do DTPA em predizer a absorção de $\mathrm{Zn}$ em cultivos subseqüentes é questionável, pois constataram uma diminuição na absorção dos metais com os cultivos consecutivos para níveis constante de extração de $Z n$.

Também Singh \& Narwall (1984), trabalhando com outra cultura, nabo forrageiro, em solos tratados com biossólidos, destacaram o DTPA como melhor extrator, dentre $\mathrm{HNO}_{3}$, água régia, $\mathrm{HCl}, \mathrm{NH}_{4} \mathrm{OAc}(\mathrm{pH} 4,8)$ e $\mathrm{H}_{2} \mathrm{O}$, em predizer a disponibilidade de $\mathrm{Zn}$ no nabo forrageiro sob diversas aplicações de biossólido e $\mathrm{pH}$ de solo.

Ao correlacionar as quantidades absorvidas de $\mathrm{Cu}, \mathrm{Cr}, \mathrm{Mn}$ e $\mathrm{Zn}$ pelas plantas de milho com os teores removidos pelos extratores $\mathrm{HCl} 0,1 \mathrm{~mol} \mathrm{~L}^{-1}$ e DTPA, Oliveira (1995) observou que ambos os extratores foram eficientes na avaliação da fitodisponibilidade do $\mathrm{Cu}$ em solos $\mathrm{AQ}$ e $\mathrm{LR}$ que receberam biossólido e na fitodisponibilidade de $\mathrm{Zn}$ apenas no solo LR. Nenhum extrator foi eficiente na previsão de quantidades fitodisponíveis de $\mathrm{Cr}$. Os extratores químicos utilizados não apresentaram correlações significativas com as quantidades de $\mathrm{Mn}$ absorvidas pelas plantas em nenhum dos solos utilizados.

Dentre os extratores utilizados, no presente estudo, o extrator Mehlich 3 foi o que apresentou correlação alta e positiva com a maioria dos teores de metais encontrados nas diversas partes da planta de milho, com exceção dos teores encontrados nos grãos. Além disso, foi o extrator que apresentou correlação alta e positiva com todos os metais analisados na FD, que é a parte da planta de milho que é empregada para avaliar o estado nutricional da cultura (Raij \& Camargo, 1996). Desta forma, este extrator poderia ser utilizado na previsão da fitodisponibilidade principalmente de $\mathrm{Cu}$ e $\mathrm{Zn}$ em plantas de milho que se desenvolvessem em solos LV e LR que tivessem recebido por longo período biossólido ou que recebessem a curto prazo altíssima aplicação deste resíduo. 


\subsection{Influência da aplicação de biossólido em alguns caracteres da planta de milho}

\subsubsection{Produtividade}

A produtividade das plantas de milho foi influenciada pelos tratamentos, sendo comprovado estatisticamente pela significância do teste $\mathrm{F}$ ao nivel de $1 \%$ (Apêndice 4.7).

Pela técnica dos contrastes ortogonais, ao se comparar tratamentos com biossólido e tratamentos com adubação convencional, considerados testemunha, verificou-se que não houve diferença significativa (Apêndice 4.8). Convém salientar que houve necessidade de adubação com $\mathrm{N}$ e $\mathrm{P}$ nos tratamentos com biossólido, devido a constatação de sintomas de deficiência destes macronutrientes (Figuras 3 e 4), apesar de ter sido adicionado via biossólido 4,0 e 3,4 $\mathrm{Mg} \mathrm{ha}^{-1}$ de $\mathrm{N}$ e $\mathrm{P}$, respectivamente.

Devido essas surpreendentes constatações, apesar de se ter conhecimento que a análise de solo não fornece parâmetros seguros para prever as respostas à adubação mineral com $\mathrm{N}$, foi realizado o teor total de $\mathrm{N}$ nos solos. Os teores totais médios de $\mathrm{N}$ nos tratamentos foram: $\mathrm{LV}=0,34 \mathrm{~g} \mathrm{~kg}^{-1} ; \mathrm{LV}+$ lodo $=0,69 \mathrm{~g} \mathrm{~kg}^{-1} ; \mathrm{LR}=0,98 \mathrm{~g} \mathrm{~kg}^{-1} \mathrm{e}$ $\mathrm{LR}+$ lodo $=1,99 \mathrm{~g} \mathrm{~kg}^{-1}$. Os resultados obtidos indicam que a aplicação de biossólido elevou o teor total de $\mathrm{N}$ no solo, estando de acordo com as observações de Bonmati et al. 1985.

A questão da taxa de mineralização da fração orgânica do biossólido e taxa de mineralização do N (TMN) é um assunto que ainda necessita estudos para as condições de solos de regiões tropicais. Mattiazzo et al. (1998) estimaram que a carga orgânica do biossólido, aplicado numa dose de $37,7 \mathrm{Mg} \mathrm{ha}^{-1}$, base seca, apresentava-se $30 \%$ degradada aos 60 dias de incubação.

Supondo-se que $20 \%$ do $\mathrm{N}$ presente no biossólido foi mineralizado após as aplicações (Raij, 1998), ter-se-ia um total de $779 \mathrm{~kg} \mathrm{ha}^{-1}$ deste elemento, mais que suficiente para atender a cultura. Na pior das hipóteses, se considerasse somente a última aplicação de biossólido que antecedeu o cultivo do milho e a ocorrência de perda por lixiviação de aproximadamente $7 \%$ (item 4.1.7), ter-se-ia $144 \mathrm{~kg} \mathrm{ha}^{-1} \mathrm{de} \mathrm{N}$, o que ainda 
seria suficiente para nutrir a cultura de acordo com Raij \& Cantarella (1996), o que não foi o observado no presente experimento.

Logo após a adubação mineral constatou-se que os sintomas desapareceram. Segundo Büll (1993), o N é um dos nutrientes que apresentam os efeitos mais espetaculares no aumento da produção de grãos na cultura do milho. Com relação ao $\mathrm{P}$, o autor comenta que os efeitos sobre a produção de grãos, embora menos pronunciados que os de N, são bem evidentes. Silva (1995), também verificou que quando se aplicou o biossólido sem suplementação de $\mathrm{N}$, houve um ligeiro amarelecimento das folhas mais velhas da cana-de-açúcar, característico da deficiência de $\mathrm{N}$. $\mathrm{O}$ autor associou este fato a possível imobilização do $\mathrm{N}$ nativo do solo, em fase inicial de mineralização do biossólido recém adicionado. Cabe ressaltar que, no presente trabalho, o cultivo do milho foi realizado dois meses após a última aplicação de biossólido. Assim, uma provável imobilização de $\mathrm{N}$ nativo do solo parece uma causa remota.

A não observância de diferenças entre os tratamentos com e sem biossólido na produtividade do milho pode ser atribuída à adubação com $\mathrm{N}$ e $\mathrm{P}$ que se fez necessária.

Utilizando a técnica dos contrates ortogonais foi possível encontrar diferenças somente entre os tratamentos que receberam aplicação de biossólido, ao nível de $1 \%$ de significância (Apêndice 4.8). Nas Figuras 31 e 32 observa-se que nos tratamentos que receberam biossólido as maiores produtividades foram obtidas com as plantas que se desenvolveram no tratamento $\mathrm{LV}+$ lodo.

Essa menor produtividade encontrada no tratamento LR+lodo em relação ao tratamento $\mathrm{LV}+$ lodo pode estar relacionada a salinidade observada neste tratamento (item 4.1.4).

As produtividades obtidas em todos os tratamentos ultrapassam a produtividade média nacional de $2.000 \mathrm{~kg} \mathrm{ha}^{-1}$ (Fancelli \& Dourado-Neto, 1997). Além disso, as produtividades obtidas nos tratamentos LV+lodo, LV e LR se aproximam muito de produtores que adotam uma tecnologia intermediária, $4.962 \mathrm{~kg} \mathrm{ha}^{-1}$ (Fancelli \& Dourado-Neto, 1997). 


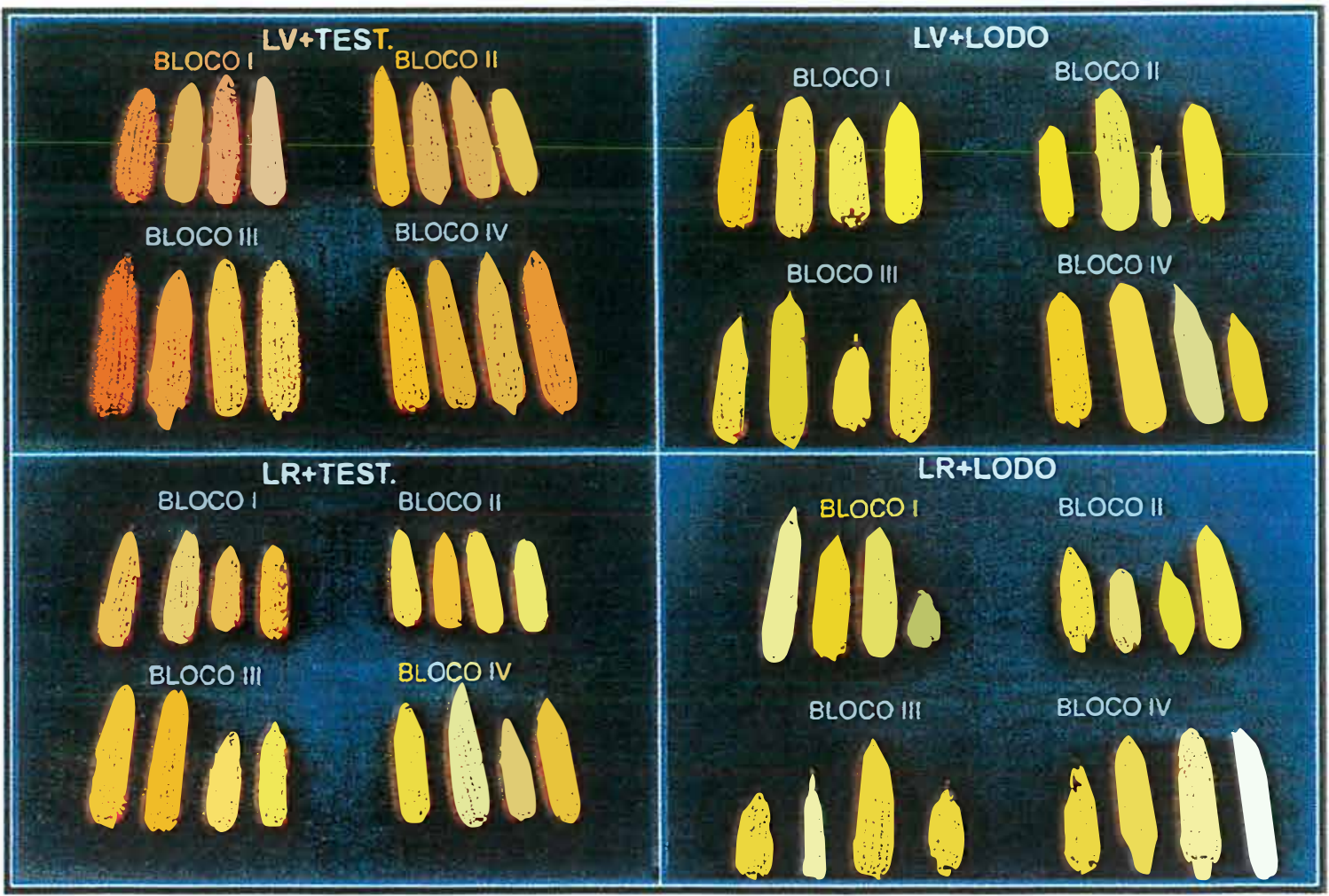

Figura 31 - Aspecto geral das espigas produzidas em cada tratamento e em cada bloco.

Se compararmos as produtividades obtidas com outras pesquisas que se utilizaram de biossólido como fonte de adubação para o milho, constata-se que a produtividade do tratamento LV+lodo foi maior que a obtida por Lourenço et al. (1996), 2.983 $\mathrm{Mg} \mathrm{ha}^{-1}$, ao trabalhar com milho em um sistema agroflorestal cultivado em área apresentando uma associação de Cambissolo textura média + Cambissolo Podzólico textura média-argilosa, aplicando $8,58 \mathrm{Mg} \mathrm{ha}^{-1}$ de biossólido, base seca. Entretanto, esta produtividade foi menor que a obtida por Biscaia \& Miranda (1996), $7.620 \mathrm{~kg} \mathrm{ha}^{-1}$, ao aplicar $60 \mathrm{Mg} \mathrm{ha}^{-1}$ de biossólido, base seca, em um Cambissolo. Convém salientar que o experimento de Biscaia \& Miranda (1996) foi realizado em solo com condições de fertilidade maior e em sistema de produção de alta tecnologia. Assim, partiu-se de um patamar de produtividade maior, em torno de $6.000 \mathrm{~kg} \mathrm{ha}^{-1}$, e o acréscimo de fertilizante (biossólido e/ou adubo mineral) elevou esta produtividade. Aumento na produtividade de milho com aplicação de biossólido também foi observado por Rappaport et al. (1988) 
e Cripps et al. (1992).

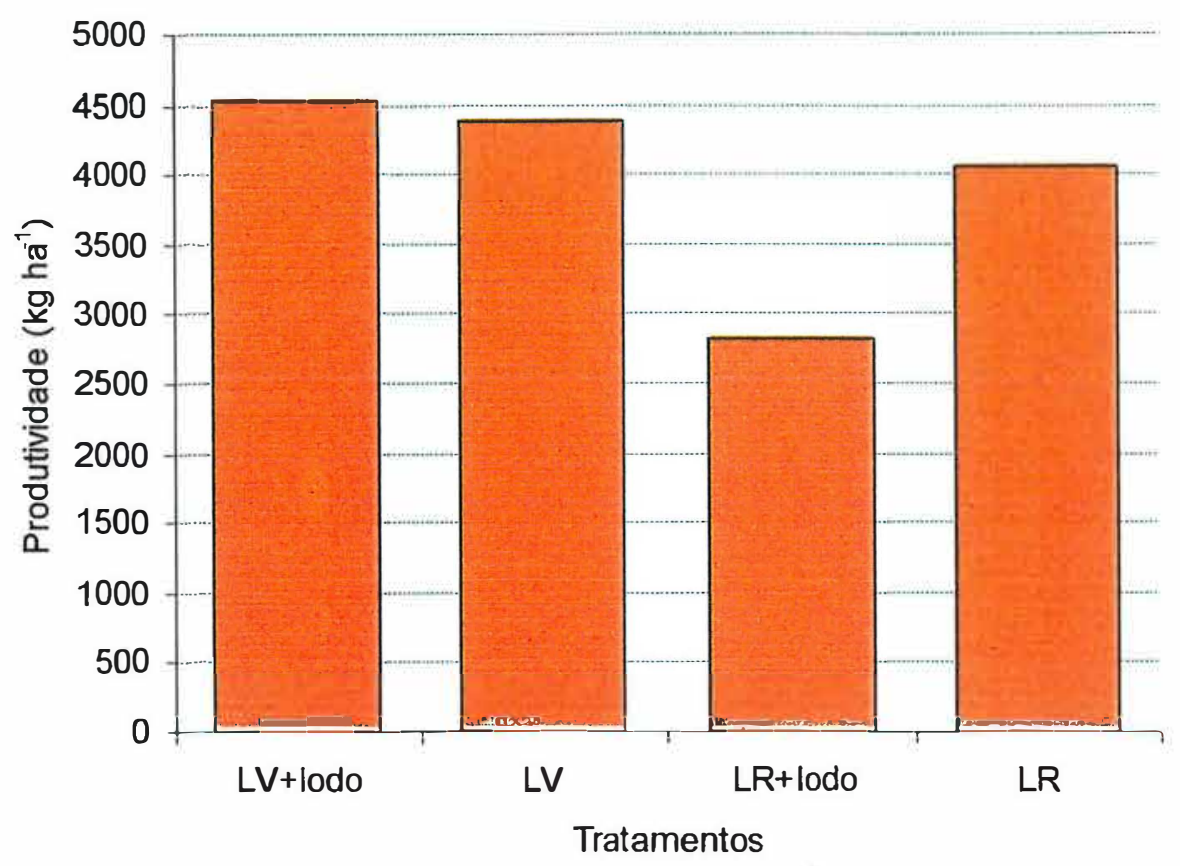

Figura 32 - Variações na produtividade das plantas de milho em função das aplicações de biossólido.

Apesar do tratamento $\mathrm{LR}+$ lodo ter recebido maior quantidade de biossólido $\left(387,89 \mathrm{~kg} \mathrm{ha}^{-1}\right.$, base seca) sua produtividade $\left(2.828 \mathrm{~kg} \mathrm{ha}^{-1}\right)$ praticamente se equivaleu a obtida por Lourenço et al. (1996). Essa tendência de menor produtividade das plantas de milho desenvolvidas em Latossolo Roxo adubado com biossólido também foi observada por Souza et al. (1998), porém ao aplicar doses de 2,49, 4,97 e 9,99 $\mathrm{kg} \mathrm{ha}^{-1}$ de biossólido em Latossolo Roxo e Latossolo Vermelho Escuro.

Neste experimento, avaliando-se somente os resultados referentes a produtividade do milho pode-se inferir que mesmo a adubação orgânica com biossólidos necessita de uma suplementação de N, P e K. 


\subsubsection{Correlação: Produtividade x Metais na planta}

Os coeficientes de correlação entre produtividade e teores (ou quantidades absorvidas) de $\mathrm{N}$ e de metais $\mathrm{Cr}, \mathrm{Cu}, \mathrm{Mn}$ e $\mathrm{Zn}$ encontrados nas diversas partes da planta levando-se em consideração todos os tratamentos e isoladamente os tratamentos com biossólido em cada solo são apresentados nas Tabelas 27, 28 e 29.

Observando estas tabelas, verifica-se que os coeficientes obtidos não apresentaram alta correlação positiva ou negativa, com exceção do $\mathrm{Zn}$ ao se levar em consideração somente o tratamento LR+lodo. Neste tratamento (Tabela 29) verificou-se que a maior absorção de $\mathrm{Zn}$ nas plantas de milho pode ter proporcionado uma significativa redução de produtividade.

Tabela 27. Coeficientes de correlação entre produtividade e teores (ou quantidades absorvidas) de $\mathrm{N}, \mathrm{Cr}, \mathrm{Cu}, \mathrm{Mn}$ e $\mathrm{Zn}$ nas diversas partes da planta, envolvendo todos os tratamentos.

\begin{tabular}{|c|c|c|c|c|c|c|c|}
\hline Espécies químicas & bainha & colmo & FD & FF & grão & palha & sabugo \\
\hline & \multicolumn{7}{|c|}{ Produtividade $\mathrm{x}$ Teores } \\
\hline $\mathrm{Cr}$ & nd & nd & nd & nd & nd & nd & 0,11 \\
\hline $\mathrm{Cu}$ & $-0,36 * *$ & $-0,18$ & $-0,33 * *$ & $-0,33 * *$ & 0,02 & $-0,26 *$ & $-0,11$ \\
\hline $\mathrm{Mn}$ & -0.12 & $-0,04$ & $-0,62 * *$ & $-0,55^{* *}$ & $-0,13$ & $-0,49 * *$ & $-0.48 * *$ \\
\hline $\mathrm{N}$ & na & na & $-0,19$ & $-0.47 * *$ & na & na & na \\
\hline \multirow[t]{2}{*}{$\mathrm{Zn}$} & $-0,10$ & $-0,11$ & $-0,12$ & $-0,27^{*}$ & $-0,13$ & $-0,06$ & $-0,27^{*}$ \\
\hline & \multicolumn{7}{|c|}{ Produtividade $\mathrm{x}$ Quantidades absorvidas } \\
\hline $\mathrm{Cr}$ & nd & nd & nd & nd & nd & nd. & $0,36^{* *}$ \\
\hline $\mathrm{Cu}$ & $-0,30^{*}$ & $-0,24$ & $-0,23 *$ & $-0,31^{*}$ & $0,36 * *$ & $-0,19$ & 0,24 \\
\hline $\mathrm{Mn}$ & -0.13 & $-0,22$ & $-0,62 * *$ & $-0.55^{* *}$ & $0,32 *$ & $-0,48 * *$ & $-0,03$ \\
\hline $\mathrm{N}$ & na & na & $-0,15$ & $-0,36 * *$ & na & na & na \\
\hline $\mathrm{Zn}$ & -0.08 & $-0,19$ & $-0,09$ & $-0,23$ & $0,40^{* *}$ & $-0,09$ & 0,02 \\
\hline
\end{tabular}

$\mathrm{FD}=$ Folha diagnose: $\mathrm{FF}=$ folhas ao final do ciclo da cultura.

nd = Não determinado. teores ou quantidades absorvidas abaixo do limite de detecção do método analítico empregado.

na $=$ Não analisado .

* = Significativo ao nivel de $5 \%(\alpha \leq 0,05)$.

$* *=$ Significativo ao nivel de $1 \%(\alpha \leq 0,01)$. 
Desta forma, a menor produtividade constatada no tratamento LR+lodo (Figuras 31 e 32) pode estar relacionada, além da salinidade observada no solo, a absorção de maiores quantidades de $\mathrm{Zn}$ pelas plantas, uma vez que, conforme comentado anteriormente, os teores médios de $\mathrm{Zn}$ encontrados na FD das plantas desenvolvidas nos tratamentos com biossólido encontravam-se bem acima da faixa considerada adequada para a cultura (Malavolta et al., 1989).

Tabela 28. Coeficientes de correlação entre produtividade e teores (ou quantidades absorvidas) de $\mathrm{N}, \mathrm{Cr}, \mathrm{Cu}, \mathrm{Mn}$ e $\mathrm{Zn}$ nas diversas partes da planta nos tratamentos LV+lodo.

\begin{tabular}{|c|c|c|c|c|c|c|c|}
\hline Espécies químicas & bainha & Colmo & $\mathrm{FD}$ & $\mathrm{FF}$ & grão & palha & sabugo \\
\hline & \multicolumn{7}{|c|}{ Produtividade $\mathrm{x}$ Teores } \\
\hline $\mathrm{Cr}$ & nd & 0,18 & nd & nd & nd & nd & 0,18 \\
\hline $\mathrm{Cu}$ & $-0,30$ & 0,08 & $-0,10$ & 0,29 & 0,25 & $-0,17$ & 0,30 \\
\hline $\mathrm{Mn}$ & 0,12 & $-0,01$ & 0,23 & $-0,12$ & 0,22 & $-0,24$ & $-0,17$ \\
\hline $\mathrm{N}$ & na & na & 0,19 & $-0,16$ & na & na & na \\
\hline \multirow[t]{2}{*}{$\mathrm{Zn}$} & $-0,13$ & $-0,09$ & 0,17 & $-0,48$ & 0,24 & $-0,08$ & 0,16 \\
\hline & \multicolumn{7}{|c|}{ Produtividade $\mathrm{x}$ Quantidades absorvidas } \\
\hline $\mathrm{Cr}$ & nd & nd & nd & nd & nd & nd & 0,36 \\
\hline $\mathrm{Cu}$ & $-0,30$ & 0,03 & $-0,13$ & 0,23 & 0,45 & $-0,24$ & 0,37 \\
\hline $\mathrm{Mn}$ & 0,10 & $-0,13$ & 0,06 & $-0,12$ & 0,44 & $-0,36$ & 0,16 \\
\hline $\mathrm{N}$ & na & na & $-0,01$ & $-0,14$ & na & na & na \\
\hline $\mathrm{Zn}$ & $-0,07$ & $-0,30$ & 0,05 & $-0,42$ & $0,4 \mathrm{l}$ & $-0,46$ & 0,38 \\
\hline
\end{tabular}

FD = Folha diagnose; $\mathrm{FF}$ = folhas ao final do ciclo da cultura.

nd = Não determinado, teores ou quantidades absorvidas abaixo do limite de deteç̧ão do método analítico empregado.

na $=$ Não analisado 
Tabela 29. Coeficientes de correlação entre produtividade e teores (ou quantidades absorvidas) de $\mathrm{N}, \mathrm{Cr}, \mathrm{Cu}, \mathrm{Mn}$ e $\mathrm{Zn}$ nas diversas partes da planta, referentes aos tratamentos LR+lodo.

\begin{tabular}{cccccccc}
\hline Espécies químicas & bainha & colmo & FD & FF & grão & palha & sabugo \\
\hline $\mathrm{Cr}$ & \multicolumn{7}{c}{ Produtividade $x$ Teores } \\
$\mathrm{Cu}$ & 0,01 & $0,66^{*}$ & $-0,37$ & 0,48 & 0,12 & 0,31 & 0,50 \\
$\mathrm{Mn}$ & 0,12 & $0,53^{*}$ & $-0,41$ & $-0,05$ & 0,09 & $-0,05$ & 0,15 \\
$\mathrm{~N}$ & $\mathrm{na}$ & na & $0,63^{*}$ & 0,36 & na & na & na \\
$\mathrm{Zn}$ & $-0,25$ & 0,29 & $-0,73^{* *}$ & $-0,26$ & 0,05 & 0,31 & 0,02 \\
\hline \hline & & \multicolumn{7}{c}{ Produtividade $\times$ Quantidades absorvidas } & \\
$\mathrm{Cr}$ & nd & nd & nd & nd & nd & nd & 0,16 \\
$\mathrm{Cu}$ & $-0,26$ & 0,44 & $-0,40$ & $-0,29$ & 0,22 & 0,52 & 0,43 \\
$\mathrm{Mn}$ & $-0,13$ & 0,20 & $-0,37$ & $-0,33$ & 0,21 & 0,16 & 0,24 \\
$\mathrm{~N}$ & na & na & 0,08 & $-0,51$ & na & na & na \\
$\mathrm{Zn}$ & $-0,32$ & 0,12 & $-0,74 * *$ & $-0,46$ & 0,23 & 0,21 & 0,04 \\
\hline
\end{tabular}

$\mathrm{FD}=$ Folha diagnose $; \mathrm{FF}=$ folhas ao final do ciclo da cultura.

nd $=$ Quantidades absorvidas abaixo do limite de detecção do método analítico empregado.

na = Não analisado.

* = Significativo ao nível de $5 \%(\alpha \leq 0,05)$.

** = Significativo ao nivel de $1 \%(\alpha \leq 0,01)$.

\subsubsection{Produção de matéria seca total e $N$ na planta}

O acúmulo de matéria seca pela cultura do milho sofre grande influência do nível de fertilidade do solo (Büll, 1993), sendo que as maiores exigências referem-se a $\mathrm{N}$ e K, seguindo-se $\mathrm{Ca}, \mathrm{Mg}$ e $\mathrm{P}$. Além disso, existe uma semelhança no ritmo de acúmulo de matéria seca e de $\mathrm{N}$ na planta (Vitti \& Favarin, 1997). Com base nestes conhecimentos é que a produção de matéria seca é discutida juntamente com o teor de $\mathrm{N}$ na planta.

A produção de matéria seca total e o $\mathrm{N}$ encontrado na folha diagnose e folhas ao final do ciclo da cultura foram influenciados pelos tratamentos, sendo comprovado estatisticamente pela significância do teste $\mathrm{F}$ ao nivel de 1\% (Apêndice 4.7).

Pela técnica dos contrates ortogonais (Apêndice 4.8) encontrou-se, ao se 
comparar os tratamentos com e sem biossólido, diferenças, ao nível de $1 \%$ de significância, entre os tratamentos para as variáveis matéria seca total e $\mathrm{N}$ na folha diagnose (N-FD) e folhas ao final do ciclo da cultura (N-FF).

$\mathrm{Na}$ Figura 33 verifica-se que os tratamentos que receberam biossólido produziram maior quantidade de matéria seca total do que os tratamentos que não receberam biossólido. Também é possível constatar que dentro dos tratamentos que receberam biossólido, as plantas desenvolvidas no LV produziram maior quantidade de matéria seca do que as desenvolvidas no LR.

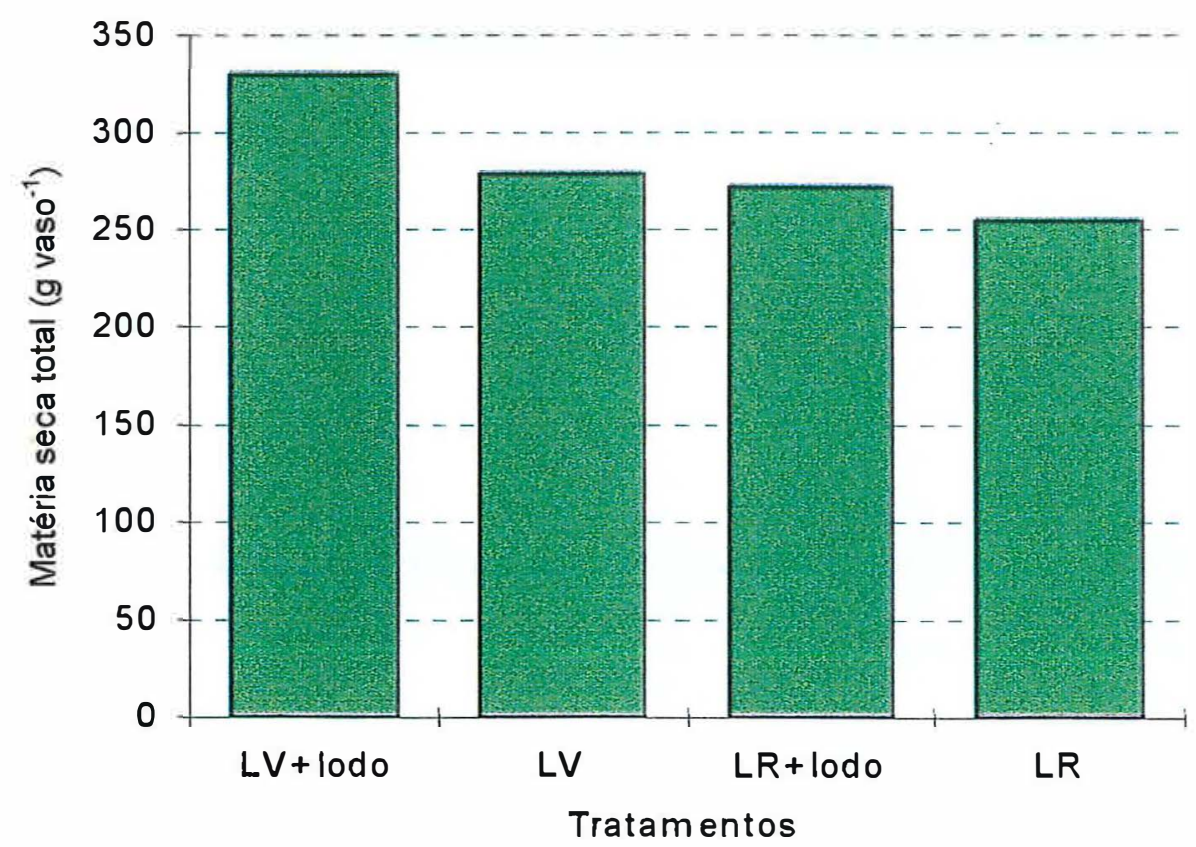

Figura 33 - Variações na produção de matéria seca total das plantas de milho em função das aplicações de biossólido.

Com relação a presença de $\mathrm{N}$ nas plantas, verificou-se que as que receberam biossólido apresentaram maiores teor e quantidade absorvida de $\mathrm{N}$ na folha diagnose (FD) e nas folhas ao final do ciclo da cultura (FF) do as plantas dos tratamentos testemunha (Figura 34 ). 
(a)

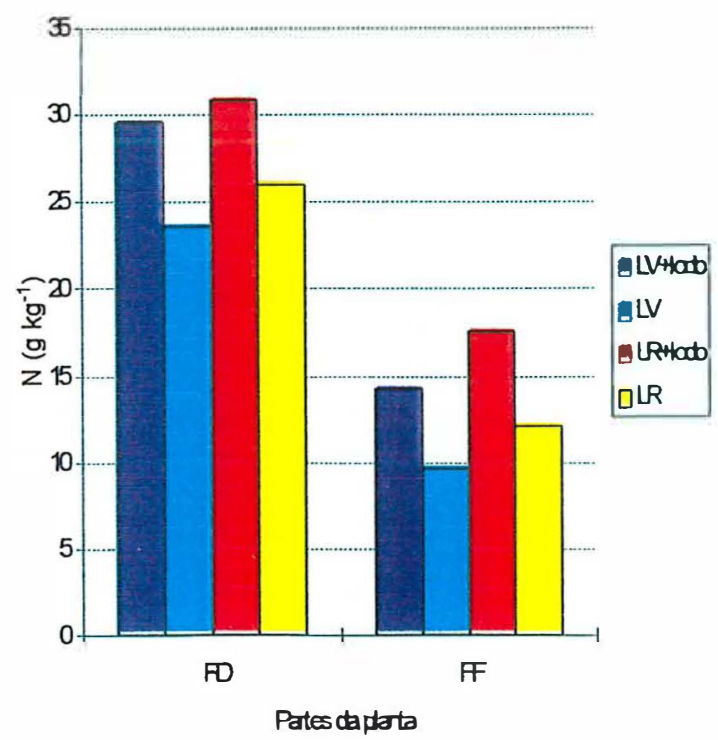

(b)

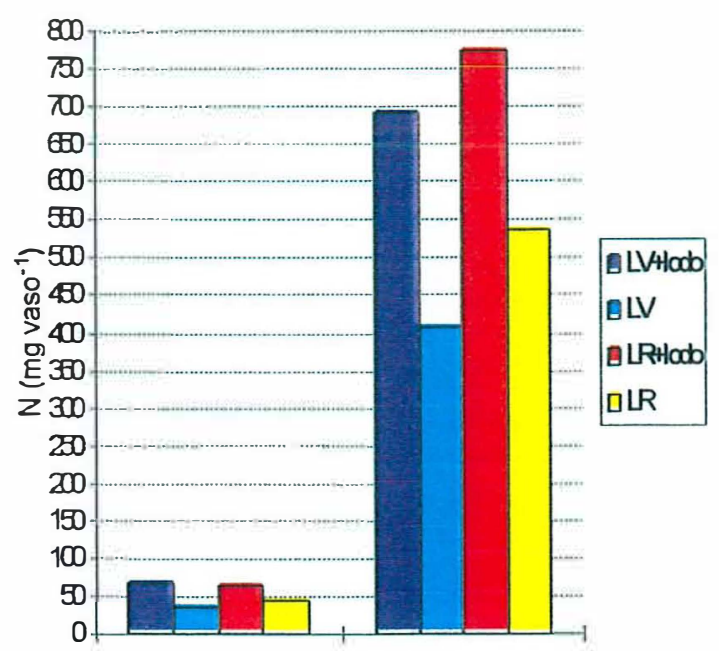

FD

Patescaplata

Figura 34 - Variações no teor (a) e na quantidade absorvida (b) de $\mathrm{N}$ encontrados na folha diagnose (FD) e nas folhas ao final do ciclo (FF) das plantas de milho em função das aplicações de biossólido.

Assim, pela diagnose foliar (FD), pode-se constatar que, apesar da necessidade de se aplicar $\mathrm{N}$ durante desenvolvimento da cultura nos tratamentos com biossólido, a aplicação deste resíduo teve efeito marcante na nutrição nitrogenada, porém este efeito não foi expresso em aumento de produtividade, conforme discutido anteriormente, e sim em aumento de produção de matéria seca. Este fato é concordante com Berton et al. (1989), Oliveira (1995) e Souza et al. (1998).

\subsubsection{Crescimento das plantas de milho: diâmetro do colmo e altura}

Nas variáveis diâmetro do colmo e altura das plantas de milho houveram diferenças significativas para Épocas de amostragem e para a interação Tratamentos $x$ 
Épocas, ao nível de 1\% (Apêndice 4.9). Na variável diâmetro do colmo o teste $\mathrm{F}$ detectou diferença significativa nos Tratamentos, ao nível de 5\%.

Pela técnica dos contrastes ortogonais (Apêndice 5.0), verificou-se nas variáveis diâmetro do colmo e altura diferenças significativas entre os tratamentos com e sem lodo de esgoto, ao nível de $5 \%$.

$\mathrm{Na}$ Figura 35 constata-se que as plantas desenvolvidas nos tratamentos testemunha apresentaram maior diâmetro do colmo e altura, até o período de 42 (estádio 3 - 8 folhas) e 56 (estádio 4 - 12 folhas) dias após a emergência, respectivamente no LV e LR. O diâmetro máximo $(34 \mathrm{~mm})$ do colmo foi atingido no $\mathrm{LV}+$ lodo, enquanto que a altura máxima $(190 \mathrm{~cm})$, no tratamento LR+lodo. Entretanto, estes valores foram atingidos após os tratamentos testemunha terem atingido seus valores máximos. Desta forma, as plantas que receberam biossólido apresentaram um ciclo vegetativo maior. Esse resultado pode estar relacionado a disponibilidade de $\mathrm{N}$ nos tratamentos com biossólido (Sikora \& Wolt, 1986; Marschner, 1995).

(a)

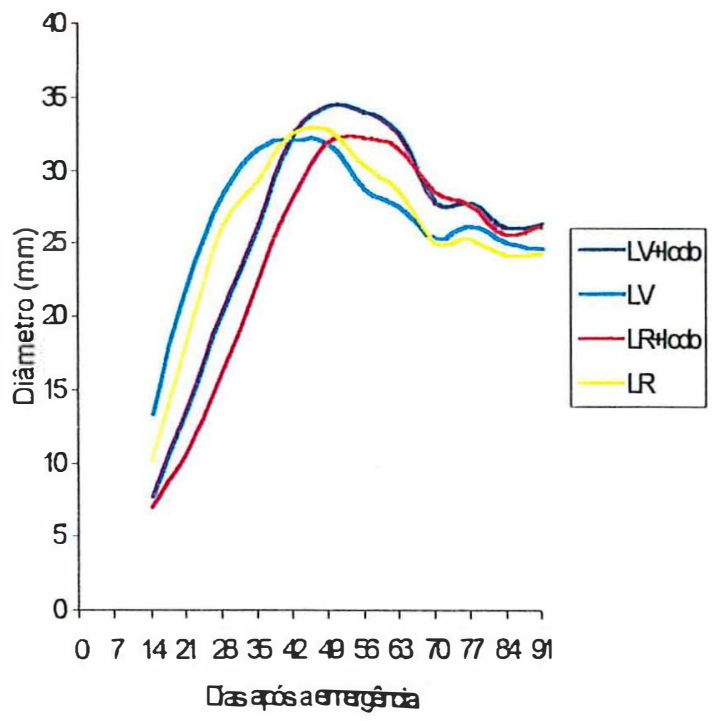

(b)

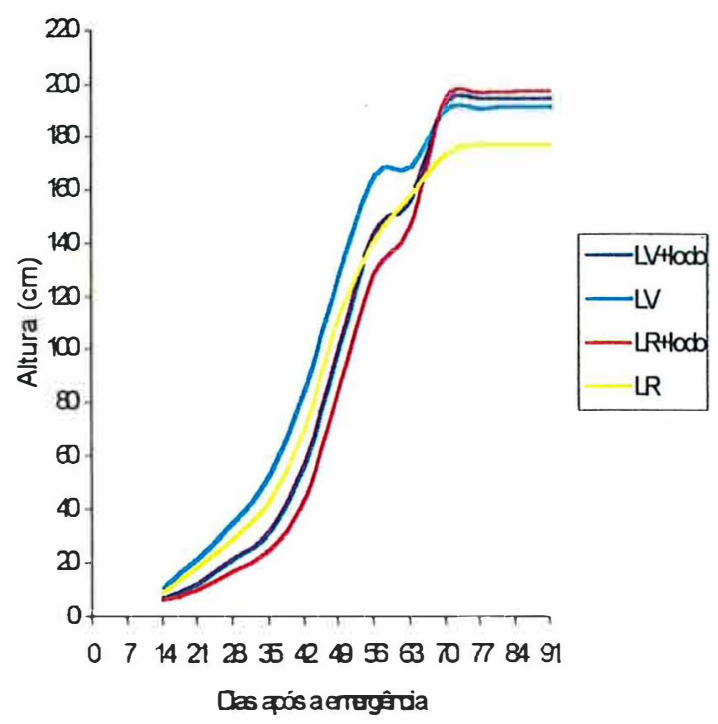

Figura 35 - Crescimento do diâmetro do colmo (a) e altura (b) durante o ciclo vegetativo do milho. 


\section{APRECIAÇÃO GERAL DOS RESULTADOS OBTIDOS}

A realização das cinco aplicações de biossólido, numa dose média de $78 \mathrm{Mg} \mathrm{ha}^{-1}$, espaçadas dois meses cada:

- tornou os solos mais salinos. A salinidade foi progressiva em função das aplicações de biossólido e manteve-se até 60 dias após a última aplicação. Esse efeito foi mais evidente no LR;

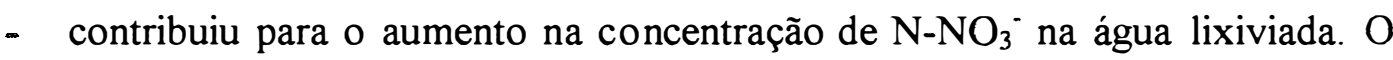
aumento foi de tal ordem que provoca preocupação quanto à contaminação de águas subterrâneas;

- aumentou a lixiviação dos cátions $\mathrm{K}^{+}, \mathrm{Mg}^{2+}$ e $\mathrm{Ca}^{2+}$, sendo a ordem de lixiviação $\mathrm{K}^{+}>\mathrm{Mg}^{2+}>\mathrm{Ca}^{2+}$. Considerando que a quantidade de $\mathrm{Mg}^{2+}$ adicionada aos solos via biossólido não foi significativa, a lixiviação deste cátion deve ser motivo de preocupação, quando da adição de biossólido, como fonte de nutriente para as culturas;

- promoveu o aumento na produção de matéria seca das plantas de milho, entretanto não foi verificado aumento de produtividade em relação aos tratamentos que só receberam a dubação mineral;

- não possibilitou a deteç̧ão dos metais $\mathrm{Cd}^{2+}, \mathrm{Cr}, \mathrm{Ni}^{2+}$ e $\mathrm{Pb}^{2+}$ no lixiviado coletado dos tratamentos e nem nas plantas de milho, embora tenham sido aplicadas, em ambos os solos, doses correspondentes, respectivamente, a 8 , 194, 141 e $60 \mathrm{~kg} \mathrm{ha}^{-1}$ via biossólido;

- não proporcionou elevação dos teores totais de $\mathrm{Cr}, \mathrm{Cu}^{2+}, \mathrm{Ni}^{2+}$ e $\mathrm{Zn}^{2+}$, extraídos pela água régia, para além dos limites críticos estabelecidos pela Agência de Proteção Ambiental dos Estados Unidos e pela Diretriz da 
Comunidade Européia. Convém salientar que os teores removidos pela metodologia adotada, em geral, estiveram abaixo dos adicionados via biossólido;

- contribuiu para aumentar os teores de $\mathrm{Cu}^{2+}$ e $\mathrm{Zn}^{2+}$ nas diversas partes da planta de milho, porém não foram observados sintomas de fitotoxicidade. Estes metais também não foram detectados nos lixiviados coletados;

- de modo geral, não alterou os teores de $\mathrm{Mn}^{2+}$ das plantas de milho.

Dentre os extratores utilizados, o Mehlich 3 foi o mais eficiente na avaliação da fitodisponibilidade de $\mathrm{Cu}^{2+}$ e $\mathrm{Zn}^{2+}$ para plantas de milho. Para os outros metais há necessidade de se definir um extrator mais adequado.

A interação dos fatores:

a) elevação do pH do solo, devido a aplicação de biossólido;

b) presença nas amostras de terra selecionadas de óxidos de $\mathrm{Fe}$ e Al;

c) presença de ligantes orgânicos;

d) elevada concentração de $\mathrm{Ca}$ na solução do solo, oriundo da aplicação de biossólido que recebeu, por questão de sanidade e estabilização, grandes quantidades de $\mathrm{CaO}$.

foram determinantes para a acumulação dos metais $\mathrm{Cd}^{2+}, \mathrm{Cr}, \mathrm{Cu}^{2+}, \mathrm{Mn}^{2+}, \mathrm{Ni}^{2+}, \mathrm{Pb}^{2+} \mathrm{e}$ $\mathrm{Zn}^{2+}$ pelos solos estudados.

Como sugestão, tendo em vista os resultados obtidos, é necessário que se estabeleça para as condições brasileiras critérios de padrão de qualidade para solo e água, no que se refere a presença de metais pesados e nitrato, respectivamente.

Também há necessidade de estudos quanto ao comportamento do $\mathrm{N}$ aplicado ao solo via biossólido, uma vez que houve necessidade de se suplementar este elemento, apesar da elevada quantidade fornecida por esse resíduo.

A reciclagem de biossólido deve ser realizada em regiões cultivadas, para que se possa sincronizar a liberação de $\mathrm{N}$ deste material com a absorção pelas plantas, reduzindo desta forma a lixiviação de nitrato. 


\section{CONCLUSÕES}

Tendo em vista os resultados obtidos conclui-se que o fator mais limitante para a utilização de biossólidos em áreas agrícolas é a ocorrência de lixiviação de $\mathrm{N}^{-\mathrm{NO}_{3}}{ }^{-}$com possibilidade de poluição do lençol freático, assim em solos de regiões de clima tropical as adições desse resíduo deve ser condicionada pela presença desse elemento.

Embora não tenha sido verificada a lixiviação dos metais $\mathrm{Cd}^{2+}, \mathrm{Cr}, \mathrm{Cu}^{2+}, \mathrm{Mn}^{2+}$, $\mathrm{Ni}^{2+}, \mathrm{Pb}^{2+}$ e $\mathrm{Zn}^{2+}$ e a passagem para a cadeia alimentar de $\mathrm{Cd}^{2+}, \mathrm{Cr}, \mathrm{Ni}^{2+}$ e $\mathrm{Pb}^{2+}, \mathrm{o}$ manejo de biossólidos em regiões de clima tropical deve levar em consideração o poder diferenciado de acumulação de metais dos solos e a possibilidade de liberação dos mesmos em função de variações nas características químicas dos solos. 


\section{REFERÊNCIAS BIBLIOGRÁFICAS}

ABREU, M.F.de; BERTON, R.S.; ANDRADE, J.C.de. Comparison of methods to evaluate heavy metals in organic wastes. Communications in Soil Science and Plant Analysis, v.27, n.5/8, p. 11 25-1135, 1996.

AINSWORTH, C.C.; PILON, J.L.; GASSMAN, P.L.; SLUYS, W.G.V.D. Cobalt, cadmium, and lead sorption to hydrous iron oxide: residence time effect. Soil Science Society of America Journal, v.58, n.6, p.1615-1623, 1994.

ALCARDE, J.C.; CHITOLINA, J.C. Determinação do nitrogênio total em solos pelo método da liga de Raney. Revista de Agricultura, v.66, n.1, p.97-106, 1991.

AL-JALOUD, A.A.; HUSSAIN, G.; AL-SAATI, A.J.; KARIMULLA, S. Effect of wastewater irrigation on mineral composition of corn and sorghum plants in a pot experiment. Journal of Plant Nutrition, v. 18, n. 8, p. 1677-1692, 1995.

ALLOWAY, B.J. Soil processes and the behaviour of metals. In: ALLOWAY, B.J. (Ed.) Heavy metals in soil. Glasgow: Blackie Academic \& Professional, 1995. cap.2, p.11-37.

AMARAL SOBRINHO, N.M.B. do; VELLOSO, A.C.X. Poluição dos solos por metais pesados. In: CONGRESSO BRASILEIRO DE CIÊNCIA DO SOLO, 24., Goiania, 1993. Anais. Goiania: SBCS, 1993. v.1. p.81-82.

ANDRÉ, E.M.; MELO, W.J.; MELO, G.M.P.; CHELLI, R.A.; LEITE, S.A.S. Metais pesados em sorgo granífero [Sorghum bicolor (L.) Moench] adubado com lodo de esgoto. In: REUNIÃO BRASILEIRA DE FERTILIDADE DO SOLO E NUTRIÇÃO DE PLANTAS, Petrolina, 1994. Anais. Petrolina: EMBRAPA; CPATSA; SBCS, 1994. p.159-161. 
ANDREOLI, C.V.; PEGORINI, E.S. Gestão de biossólidos: situação e perspectivas. In: SEMINÁRIO SOBRE GERENCIAMENTO DE BIOSSÓLIDOS DO MERCOSUL, 1., Curitiba, 1998. Anais. Curitiba: SANEPAR; ABEAS, 1998. p.11-18.

ANDREOLI, C.V.; FERNANDES, F.; DOMASZAK, S.C. Reciclagem agrícola do lodo de esgoto: estudo preliminar para definição de critérios para uso agronômico e de parâmetros para normatização ambiental e sanitária. Curitiba: Sanepar, 1997. $81 \mathrm{p}$.

ARTIOLA, J.F. Temporal and spatial distributions of nitrate-nitrogen in two furrowirrigated semiarid soils amended for sludge and fertilizer. Communications in Soil Science and Plant Analysis, v.29, n.3/4, p.393-407, 1998.

BARRETTO, M.C.V. Degradação da fração orgânica de diferentes resíduos e efeitos em algumas propriedades químicas e físicas de dois solos. Piracicaba, 1995. 106p. Tese (Doutorado) - Escola Superior de Agricultura "Luiz de Queiroz", Universidade de São Paulo.

BAXTER, J.C.; AGULAR, M.; BROWN, K. Heavy metals and persistent organics at a sewage sludge disposal site. Journal of Environmental Quality, v.12, n.3, p.311$316,1983$.

BENCKISER,G.; SIMARMATA, T. Environmental impact of fertilinzing soils by using sewage and animal wates. Fertilizer Research, v.37, n. 1, p. 1-22,1994.

BERTI, W.R.; JACOBS, L.W. Chemistry and phytotoxicity of soil trace elements from repeated sewage sludge applications. Journal of Environmental Quality, v.25, n.5, p. 1025-1032, 1996. 
BERTON, R.S.; CAMARGO, O.A.; VALADARES, J.M.A.S. Absorção de nutrientes pelo milho em resposta à adição de lodo de esgoto a cinco solos paulistas. Revista Brasileira de Ciência do Solo, v. 13, n.2, p. 187-192, 1989.

BERTONCINI, E. I. Mobilidade de metais pesados em solos tratados com lodo de esgoto. Piracicaba, 1997. 90p. Dissertação (Mestrado) - Escola Superior de Agricultura "Luiz de Queiroz", Universidade de São Paulo.

BETTIOL, W.; CARVALHO, P.C.T.; FRANCO, B.J.D.C. Utilização do lodo de esgoto como fertilizante. O Solo, v.75, n.1, p.44-54, 1983.

BIDONE, F.R.A. Alternativas de disposição final de biossólidos: aterros, landfarming e incineração. In: SEMINÁRIO SOBRE GERENCIAMENTO DE BIOSSÓLIDOS DO MERCOSUL, 1., Curitiba, 1998. Anais. Curitiba: SANEPAR; ABEAS, 1998. p.131-135.

BIDWELL, A.M.; DOWDY, R.H. Cadmium and zinc availability to corn following termination of sewage sludge applications. Journal of Environmental Quality, v. 16, n. 4, p. $438-442,1987$.

BISCAIA, R.C.M.; MIRANDA, G.M. Uso de lodo de esgoto calado na produção de milho. Sanare, v.5, n.5, p.86-89, 1996.

BLADEL, R.van; GHEYI, H.R. Thermodynamic study of calcium-sodium and calciummagnesium exchange in calcareous solis. Soil Science Society of America Journal, v.44, n. 5, p.938-942, 1980. 
BOARETTO, R.S.; MURAOKA, T.; NAKAGAWA, J.; CHHTOLINA, J.C. Níquel e cádmio em grãos de feijão produzidos em solo adubado com lodo de esgoto. In: REUNIÃO BRASILEIRA DE FERTILIDADE DO SOLO E NUTRIÇÃO DE PLANTAS, 20., Piracicaba, 1992. Adubação, produtividade, ecologia: anais. Piracicaba: SBCS, 1992. p.400-401.

BONMATI, M.; PUJOLA,M.; SANA, J.; SOLIVA, M. Chemical properties, populations of nitrite oxidizers, urease and phosphatase activies in sewage sludgeamended soils. Plant and Soil, v.84, n.1, p.79-91, 1985.

BORKERT, C.M. Manganês. In: FERREIRA, M.E.; CRUZ, M.C.P. (Ed.) Micronutrientes na agricultura. Piracicaba: POTAFOS; CNPq, 1991. p.173-190.

BRASIL. Presidência da República. Comissão Interministerial para Preparação da Conferência das Nações Unidas sobre o Meio Ambiente e Desenvolvimento. $\mathbf{O}$ desafio do desenvolvimento sustentável: relatório do Brasil para a Conferência das Nações Unidas sobre o Meio Ambiente e Desenvolvimento. Brasília, 1991. 204 p.

BÜLL, L.T. Nutrição mineral do milho. In: BÜLL, L.T.; CANTARELLA, H. (Ed.) Cultura do milho: fatores que afetam a produtividade. Piracicaba: POTAFOS, 1993. p.63-145.

CAMARGO, O.A. de; MONIZ, A.C.; JORGE, J.A.; VALADARES, J.M.A.S. Métodos de análise química, mineralógica e física de solos do Instituto Agronômico de Campinas. Campinas: IAC, 1986. 94p. (IAC. Boletim Técnico, 106).

CAMOBRECO, V.J.; RICHARDS, B.K.; STEENHUIS, T.S.; PEVERLY, J.H.; McBRIDE, M.B. Movement of heavy through undisturbed and homogenized soil columns. Soil Science, v.161, n.11, p.740-750, 1996. 
CAMPBELL, D.J.; BECKETT, P.H.T. The soil solution in a treated with digest sewage sludge. Journal of Soil Science, v.39, n.2, p.283-298, 1988.

CARTRON, J.M.; WEIL, R.R. Seasonal trends in soil nitrogen from injected or surfaceincorporated sewage sludge applied to com. Communications in Soil Science and Plant Analysis, v.29, n.1/2, p.121-139, 1998.

CARVALHO, P. C. de; BARRAL, M.F. Aplicação de lodo de esgoto como fertilizante. Fertilizantes, v.3, n.2, p.1-5, 1981.

CHANG, A.C.; HYUN, H.-nam.; PAGE, A.L. Cadmium uptake for swiss chard grown on composted sewage sludge treated field plots: plateau or time bomb? Journal of Environmental Quality, v.26, n.1, p.11-19, 1997.

CHANG, A.C.; WARNEKE, J.E.; PAGE, A.L.; LUND, L.J. Accumulation of heavy metals in sewage sludge-treated solis. Journal of Environmental Quality, v.13, n. 1, p. $87-91,1984$.

CHANG, A.C.; HINESLY, T.D.; BATES, T.E.; DONER, H.E.; DOWDY, R.H.; RYAN, J.A. Effects of long-term sludge application on accumulation of trace elements by crops. In: PAGE, A.L.; LOGAN, T.G.; RYAN, J.A. Land application of sludge. Chelsea: Lewis Publishers, 1987. cap.4, p.53-66.

CHAVES, L.H.G.; LIBARDI, P.L. Lixiviação de potássio e cálcio mais magnésio influenciada pelo pH. Revista Brasileira de Ciência do Solo, v.19, n.1, p.145-148, 1995.

COX, D.A. Pelletized sewage sludge as a fertilizer for containerized plants: plant growth and nitrogen leaching losses. Journal of Plant Nutrition, v.18, n.12, p.2783-2795, 1995. 
CRIPPS, R.W.; MATOCHA, J.E. Effect of sewage sludge application to ameliorate iron deficiency of grain sorghum. Communications in Soil Science and Plant Analysis, v.22, n.17/18, p.1931-1940, 1991.

CRIPPS, R.W.; WINFREE, S.K.; REAGAN, J.L. Effects of sewage sludge application method on corn production. Communications in Soil Science and Plant Analysis, v.23, n. 15/16, p.1705-1715, 1992.

CUNNINGHAM, I.D.; KEENEY, D.R.; RYAN, J.A. Yield and metal composition of crop and rye grown on sewage ammended soil. Journal of Environmental Quality, v.4, n.4, p.448-454, 1975.

DOWDY, R.H.; LATTERELL, J.J.; HINESLEY, T.D.; GROSSMAN, R.D.; SULLIVAN, D.L. Trace metal movement in na aeric ochraqualf folowing 14 years of annual sludge applications. Journal of Environmental Quality, v.20, n. 1, p.119123, 1991.

EATON, A.D.; CLESCERI, L.S.; GRENNBERG, A.E. Standard methods for the examination of water and wastewater. 19.ed. Washington: APHA, AWWA, WEF, 1995. 1082p.

EPSTEIN, E.; TAYLOR, J.M.; CHANEY, R.L. Effects of sewage sludge and sludge compost applied to soil on some soil physical and chemical properties. Journal of Environmental Quality, v.5, n.4, p.422-426, 1976.

FANCELLI, A.L.; DOURADO-NETO, D. (Coord.) Tecnologia da produção de milho. Piracicaba: Publique, 1997. 174p. 
FRESQUEZ, P.R.; FRANCIS, R.E.; DENNIS, G.L. Sewage sludges effects on soil and plant quality in a degraded, semiarid grassland. Journal of Environmental Quality, v.19, n.2, p.324-329, 1990.

GAMBRELL, R.P. Trace and toxic metals in wetlands: a review. Journal of Environmental Quality, v.23, n.5, p.883-891, 1994.

GAVI, F.; RAUN, W.R.; BASTA, N.T.; JOHNSON, G.V. Effect of sewage sludge and ammonium nitrate on wheat yield and soil profile inorganic nitrogen accumulation. Journal of Plant Nutrition, v.20, n.2/3, p.203-218, 1997.

GOMES, F.P. Curso de estatística experimental. 12.ed. Piracicaba: Livraria Nobel, 1987. $466 \mathrm{p}$.

GOULDING, K.W.T.; TALIBUDEEN, O. Thermodynamics of K-Ca exchange in soils. II. Effects of mineralogy, residual $\mathrm{K}$ and $\mathrm{pH}$ in soils from long term ADAS experiments. Journal of Soil Science, v.35, n.3, p.409-420, 1984.

HALL, J. Standardising and the management of biosolids the international experience. In: SEMINÁRIO SOBRE GERENCIAMENTO DE BIOSSÓLIDOS DO MERCOSUL, 1., Curitiba, 1998. Anais. Curitiba: SANEPAR; ABEAS, 1998. p.113-122.

HANDRECK, K.A. Effect of $\mathrm{pH}$ on the uptake of cadmium, copper, and zinc from soilless media containing sewage sludge. Communications in Soil Science and Plant Analysis, v.25, n.11/12, p.1913-1927, 1994.

HARTER, R.D. Competitive sorption of cobalt, copper, and nickel ions by a calciumsaturated soil. Soil Science Society of America Journal, v.56, n.2, p.444-449, 1992. 
HEGSTROM, L.J.; WEST, S.D. Heavy metal accumulation in samall mammals following sewage sludge application to forests. Journal of Environmental Quality, v. 18, n.3, p.345=349, 1989.

HOAGLIN, D.C.; MOSTELLER, F.; TUKEY, J.W. Análise exploratória de dados: técnicas robustas. Lisboa: John Wiley, 1992. 446p.

HUE, N.V. Sewage sludge. In: RECHCIGL, J.E. (Ed.) Soil amendments and environmental quality. Boca Raton: CRC Press, 1995. cap.6, p.199-247.

HUE, N.V.; SILVA, J.A.; ARIFIN, R. Sewage sludge-soil interactions as measured by plant and soil chemical composition. Journal of Environmental Quality, v. 17, n.3, p. 384-390, 1988.

HUNGRIA, M.; URQUIAGA, S. Transformações microbianas de outros elementos: potásssio, micronutrientes e metais pesados. In: CARDOSO, E.J.B.N.; TSAI, S.M.; NEVES, M.C.P. (Coord.) Microbiologia do solo. Campinas: Sociedade Brasileira de Ciência do Solo, 1992. cap.23, p.329-340.

JNG, J.; LOGAN, T.J. Effects of sewage sludge cadmium concentration on chemical extractability and plant uptake. Journal of Environmental Quality, v.21, n.1, p.73$81,1992$.

JONES, R.L.; HINESLY, T.D. Potassium losses in runoff and drainage waters from cropped, large-scale lysimeters. Journal of Environmental Quality, v.15, n.2, p.137-140, 1986.

JONES, R.L.; HINESLY, T.D. Nitrate in waters from sewage-sludge amended lysimeters. Journal of Environmental Quality, v.51, n.1, p. 19-30, 1988. 
JONES JR., J.B. A guide for the hydroponic \& soilless culture grower. Portland: Timber Press, 1983. 124p.

JORGE, J.A.; CAMARGO, O.A.; VALADARES, J.M.A.S. Condições físicas de um latossolo vermelho escuro quatro anos após aplicação de lodo de esgoto e calcário. Revista Brasileira de Ciência do Solo, v. 15, n.3, p.237-240, 1991.

KABATA-PENDIAS, A.; PENDIAS, $H$. Trace elements in soils and plantas. 3.ed. Boca Raton: CRC Press, 1985. 315p.

KALBASI, M.; RACZ, G.J.; LOEWEN-RUDGERS, L.A. Mechanism of zinc adsorption by iron and aluminum oxides. Soil Science, v. 125, n.3, p. 146-150, 1978.

KELLER, C.; VÉDY, J.C. Distribuition of copper and cadmium fractions in two forest soils. Journal of Environmental Quality, v.23, n.5, p.987-999, 1994.

KIM, S.J.; CHANG, A.C.; PAGE, A.L.; WARNEKE, J.E. Relative concentrations of cadium and zinc in tissue of selected food plants grown on sludge-treated soils. Journal of Environmental Quality, v.17, n.14, p.568-573, 1988.

KING, L.D.; HAJJAR, L.M. The residual effect of sewage sludge on heavy metal content of tobacco and peanut. Journal of Environmental Quality, v.19, n.4, p.738-748, 1990.

KOCHE, A.; HANASIRO, J.; SANTOS, A.R. dos; ROMERO, A.M.S.; LAVIGNE, M. de; GUIDOLIN, J.A.; ALCARDE, J.C. Análise de corretivos agrícolas. São Paulo: ANDA, 1989. 30p. 
KORCAK, R.F.; FANNING, D.S. Extractability of cadmium, copper, nickel and zinc by double acid versus DTPA and plant content at excessive soil levels. Journal of Environmental Quality, v.7, n.4, p.506-512, 1978.

LADONIN, D.V.; MARGOLINA, S.E. Interaction between humic acids and heavy metals. Eurasian Soil Science, v.30, n. 7, p.710-715, 1997.

LAKE, D.L.; KIRK, P.W.W.; LESTER, J.N. Fractions, characterization, and speciation of heavy metals in sewage sludge and sludge-amended soils: a review. Journal of Environmental Quality, v. 13, n.2, p.175-183, 1984.

LAMY, I.; BOURGEOIS, S.; BERMOND. A. Soil cadmium mobility as a consequence of sewage sludge disposal. Journal of Environmental Quality, v.22, n.4, p.731$737,1993$.

LINDEN, D.R.; CLAPP, C.E.; DOWDOY, R.H. Hydrologic management: nutrients. In: PAGE, A.L.; GEASON, T.L.; SMITH, J.E.; ISKANDAR, J.K.; SOMMERS, L.E. (Ed.) Utilization of municipal wastewater and sludge on land. Riverside: University of California, 1983. p.79-103.

LINDSAY, W.L.; NORWELL, W.A. Development of DTPA soil test for zinc, iron, manganese and copper. Soil Science Society of America Journal, v.42, n.3, p.421$428,1978$.

LOGAN, T.J.; CHANEY, R.L. Metals. In: WORKSHOP ON UTILIZATION OF MUNICIPAL WASTERWATER AND SLUDGE ON LAND, Riverside, 1983. Proceedings. Riverside: University of California, 1983. p.235-326. 
LOGAN, T.J.; HARRISON, B.J. Physical characteristics of alkaline stabilized sewage sludge (N-Viro soil) and their effects on soil physical properties. Journal of Environmental Quality, v.24, n. 1, p.153-164, 1995.

LOGAN, T.J.; LINDSAY, B.J.; GOINS, L.E.; RYAN, J.A. Field assessment of sludge metal bioavailability to crops: sludge rate response. Journal of Environmental Quality, v.26, n.2, p.534-550, 1997.

LOURENÇO, R.S.; ANJOS, A.R.M. dos; LIBARDI, P.L.; MEDRADO, M.J.S. Efeito do lodo de esgoto na produtividade de milho e feijão no sistema de produção da bracatinga. Sanare, v. 5, n.5, p.90-92, 1996.

LUCCHESI, L.A.C. Características dos biossólidos e efeitos de sua reciclagem em ambientes edáficos com ênfase na dinâmica de elementos traço. In: SEMINÁRIO SOBRE GERENCIAMENTO DE BIOSSÓLIDOS DO MERCOSUL, 1., Curitiba, 1998. Anais. Curitiba: SANEPAR; ABEAS, 1998. p.77-83.

LUDUVICE, M. Gestão de biossólidos e o Mercosul. In: SEMINÁRIO SOBRE GERENCIAMENTO DE BIOSSÓLIDOS DO MERCOSUL, 1., Curitiba, 1998. Anais. Curitiba: SANEPAR; ABEAS, 1998. p.9-10.

LUND, L.J.; PAGE, A.L.; NELSON, C.O. Movement of heavy metal below sewage disposal ponds. Journal of Environmental Quality, v.5, n.3, p.330-334, 1976.

MALAVOLTA, E.; VITTI, G.C.; OLIVEIRA, S.A. Avaliação do estado nutricional de plantas: princípios e aplicações. Piracicaba: Associação Brasileira para Pesquisa da Potassa e do Fosfato, 1989. 201p.

MANN, S.S.; RITCHIE, G.S.P. Forms of cadmium in sandy soils after amendment with soils of higher fixing capacity. Environmental Pollution, v.87, n. 1, p.23-29, 1995. 
MARQUES, M.O.; BELLINGIERI, P.A. MELLO, W.J.; MARQUES, T.A.; OLIVEIRA, F.C.; SANTIAGO, G. Reciclagem de nutrientes no solo com a aplicação de lodo de esgoto. Ciência Agronômica, v.6, n.1, p.24-29, 1991.

MARSCHNER, H. Mineral nutrition of higher plantas. 2.ed. London: Academic Press, 1995. 889p.

MATTIAZZO, M.E.; BARRETTO, M.C.V.; RODELLA, A.A. Organic matter kinetics mineralization in soils amended with four diffrent organic wates (compact disc). In: CONGRESS MONDIAL DE SCIENCE DU SOL, 16., Montpellier, 1998. Actes. Montpellier: ISSS, 1998.

MATTIAZZO-PREZOTTO, M.E. Comportamento de $\mathrm{Cu}, \mathrm{Cd}, \mathrm{Cr}$, $\mathrm{Ni}$ e $\mathrm{Zn}$ adicionados à solos de clima tropical em diferentes valores de pH. Piracicaba, 1994. 197p. Tese (Livre-Docência) - Escola Superior de Agricultura "Luiz de Queiroz", Universidade de São Paulo.

McBRIDE, M.B. Toxic metal accumulation from agricultural use of sludge: Are USEPA regulations protective? Journal of Environmental Quality, v.24, n.1, p.5$18,1995$.

MEDALIE, L.; BOWDEN, W.B.; SMITH, C.T. Nutrient leaching following land application of aerobically digested municipal sewage sludge in a northen hardwood forest. Journal of Environmental Quality, v.23, n. 1, p.130-138, 1994.

MEHLICH, A. Mehlich $n^{\circ} 3$ soil test extractant: a modification of Mehlich $n^{\circ} 2$. Communications in Soil Science and Plant Analysis, v.15, n.12, p.1409-1416, 1984. 
MELLO, F.A.F. de; BRASIL SOBRINHO, M.O.C. do; ARZOLLA, S.; SILVEIRA, R.I.; COBRA NETTO, A.; KIEHL, J.C. Fertilidade do solo. 3.ed. São Paulo: Nobel, 1989. 400p.

MELO, W.J; MARQUES, M.O.; SANTIAGO, G.; CHELLI, R.A.; LEITE, S.A.S. Efeito de doses crescentes de lodo de esgoto sobre frações da matéria orgânica e CTC de um latossolo cultivado com cana-de-açúcar. Revista Brasileira de Ciência do Solo, v. 18, n.3, p.449-455, 1994.

MENCH, M.; CLAIRON, M.; SOBESKY, O.; NAGOU, D. Dynamique en temps court de lázote mineral en sol ferrallitique nu après apport dúne boue urbaine. Agronomie, v.9, n.8, p.785-793, 1989.

MINER, G.S.; GUTIERREZ, R.; KING, L.D. Soil factors plant concentrations of cadmium, copper, and zinc on sludge-amended soils. Journal of Environmental Quality, v.26, n.4, p.989-994,1997.

MISSELBROOK, T.H.; SHEPHERD, M.A.; PAIN, B.F. Sewage sludge applications to grassland: influence of type, time and method of application on nitrate leaching and herbage yield. Journal of Agricultural Science, v.126, n.3, p.343-352, 1996.

MIYAZAWA, M.; KAMAGAWA, M.Y.; MATTOS, M.S.; MORAES, S.R. de.; PARRA, M.S. Lixiviação de metais pesados do lodo de esgoto no solo. Sanare, v.5, n.5, p.63-67, 1996.

MULCHI, C.L.; ADAMU, C.A.; BELL, P.F.; CHANEY, R.L. Residual heavy metal concentrations in sludge-amended coastal plain soils - I. Comparison of extractants. Communications in Soil Science and Plant Analysis, v.22, n.9/10, p.919 -941, 1991. 
NIEUWENHUIZE, J.; POLEY-VOS, C.H.; AKKER, A.H. van den; DELFT, W. van. Comparison of microwave and conventional extraction techniques for the determination of metals in soil, sediment and sludge samples by atomic spectrometry. Analyst, v. 116, n.4, p.347-351, 1991.

OLIVEIRA, F.C. Metais pesados e formas nitrogenadas em solos tratados com lodo de esgoto. Piracicaba, 1995. 90p. Dissertação (Mestrado) - Escola Superior de Agricultura "Luiz de Queiroz", Universidade de São Paulo.

OLIVEIRA, F.C.; MARQUES, M.O.; BELLINGIERI, P.A.; PERECIN, D. Lodo de esgoto como fonte de macronutrientes para a cultura do sorgo granífero. Scientia Agricola, v. 52, n.2, p.360-367, 1995.

PAGE, A.L.; MILLER, R.H.; KEENEY, D.F. Methods of soil analysis. 2.ed. Madison: ASA; SSSA, 1982. 1159p.

PELCZAR, M.; REID, R.; CHAN, E.C.S. Microbiologia. São Paulo: Mc Graw-Hill do Brasil. 1980. v.1, 554p.

PETRUZZELLI, G. Recycling wastes in agriculture: heavy metal bioavailability. Agriculture, Ecosystems and Environment, v.27, n. 1/4, p.493-503, 1989.

PIERRISNARD, F. Impact de l'amendement des boues residuaires de la ville de Marseille sur des sols a vocation agricole: comportement du $\mathrm{Cd}, \mathrm{Cr}, \mathrm{Cu}, \mathrm{Ni}, \mathrm{Pb}, \mathrm{Zn}$, des hydrocarbures et des composes polaires. Marseille, 1996. 408p. These (Docteur) - Facolte des Sciences et Techniques de Saint-Jerome, Universite de Droit d'Ecomonie et des Sciences d'AIX-MARSEILLE. 
PIRES, A.M.M. Disponibilidade de $\mathrm{Zn}$ e $\mathrm{Cu}$ adicionados a solos via lodo de esgoto para plantas de arroz. Piracicaba, 1998. 55p. Dissertação (Mestrado) - Escola Superior de Agricuitura "Luiz de Queiroz", Universidade de São Paulo.

POMBO, L.C.A.; KLAMT, E. Adsorção de zinco e cobre de dois solos do Estado do Rio Grande do Sul. Revista Brasileira de Ciência do Solo, v.10, n.3, p.191-194, 1986.

RAIJ, B. van. Fertilidade do solo e adubação. Piracicaba: Ceres; Potafos, 1991. $343 p$.

RAIJ, B. van. Uso agrícola de biossólidos. In: SEMINÁRIO SOBRE GERENCIAMENTO DE BIOSSÓLIDOS DO MERCOSUL, 1., Curitiba, 1998 Anais. Curitiba: SANEPAR; ABEAS, 1998. p.147-151.

RAIJ, B. van; CAMARGO, C.E.O. Cereais. In: RAIJ, B. van; CANTARELLA, H.; QUAGGIO, J.A.; FURLANI, A.M.C. (Ed.) Recomendações de adubação e calagem para o Estado de São Paulo. 2.ed. Campinas: Instituto Agronômico, 1996. p.45-71. (IAC. Boletim Técnico, 100).

RAIJ, B. van; CANTARELLA, H. Milho para grãos e silagem. In: RAIJ, B. van; CANTARElla, H.; QUAGgIO, J.A.; FURLANI, A.M.C. (Ed.) Recomendações de adubação e calagem para o Estado de São Paulo. 2.ed. Campinas: Instituto Agronômico, 1996. p.56-59. (IAC. Boletim Técnico, 100).

RAIJ, B. van; QUAGGIO, J.A.; CANTARELLA, H.; FERREIRA, M.E.; LOPES, A.S.; BATAGLIA, O.C. Análise química do solo para fins de fertilidade. Campinas: Fundação Cargill, 1987. 170p. 
RAPPAPORT, B.D.; MARTENS, D.C.; RENEAU JR., R.B.; SIMPSON, T.W. Metal availability in sludge-amended soils with elevated metals levels. Journal of Environmental Quality, v. 17, n. 1, p.42-47, 1988.

REDDY, K.J.; WANG, L.; GLOSS, S.P. Solubility and mobility of copper, zinc and lead in acidic environments. Plant and Soil, v.171, n.1, p.53-58, 1995.

REDDY, M.R.; LAMECK, D.; REZANIA, M.E. Uptake and distribuition of copper and zinc by soybean and corn from soil treated with sewage sludge. Plant and Soil, v.113, n.2, p.271-274, 1989.

REIS, T.C. Variação da acidez do solo em resposta à adição de materiais orgânicos. Piracicaba, 1998. 65p. Dissertação (Mestrado) - Escola Superior de Agricultura "Luiz de Queiroz", Universidade de São Paulo.

RIEKERK, $\mathrm{H}$. The behavior of nutrient elements added to a forest soil with sewage sludge. Soil Sciencie Society of America Journal, v.42, n. 5, p.810-816, 1978.

RITTER, W.F.; EASTBURN, R.P. The uptake of heavy metals from sewage sludge applied to land by corn and soybeans. Communications in Soil Science and Plant Analysis, v.9, n.9, p.799-811, 1978.

ROCA, J.; POMARES, F. Prediction of available heavy metals by six chemical extractants in a sewage sludge-amended soil. Communications in Soil Science and Plant Analysis. v.22, n. 19/20, p.2119-2136, 1991.

RODELLA, A.A. Métodos de avaliação de materiais orgânicos e efeitos de sua incorporação ao solo sobre a mobilização de macronutientes. Piracicaba, 1996, 148p. Tese (Livre-Docència) - Escola Superior de Agricultura "Luiz de Queiroz", Universidade de São Paulo. 
ROGALLA, F. Produção, caracterização e processamento de biossólidos. In: SEMINÁRIO SOBRE GERENCIAMENTO DE BIOSSÓLIDOS DO MERCOSUL, 1., Curitiba, 1998. Anais. Curitiba: SANEPAR; ABEAS, 1998. p.35-40.

SALAZAR, I.; FAUNDEZ, K.; PINILLA, H.; PINO, M.; MORA, M.L. Efecto de la acidez sobre la selectividad de intercambio $\mathrm{Ca} / \mathrm{K}$ en dos suelos del sur de Chile. Turrialba, v.45, n.3/4, p.120-127, 1995.

SANTOS, H.F. dos. Normas e critérios para o uso agricola dos biossólidos de estações de tratamento de esgotos (ETEs). In: SEMINÁRIO SOBRE GERENCIAMENTO DE BIOSSÓlIDOS DO MERCOSUL, 1., Curitiba, 1998. Anais. Curitiba: SANEPAR; ABEAS, 1998. p.123-129.

SARRUGE, J.R.; HAAG, H.P. Análise química em plantas. Piracicaba: ESALQ, 1974. 56p.

SEMINÁRIO SOBRE GERENCIAMENTO DE BIOSSÓLIDOS DO MERCOSUL, Curitiba, 1998. Anais. Curitiba: SANEPAR; ABES, 1998. 326p.

SHEPHERD, M.A. Factors affecting nitrate leaching from sewage sludges applied to a sandy soil in arable agriculture. Agriculture, Ecosystems \& Environment, v.58, n.2/3, p.171-185, 1996.

SIKORA, F.J.; WOLT, J. Effect of cadmium- and zinc-treated sludge on yield and cadmium-zinc uptake of corn. Journal of Environmental Quality, v.15, n.4, p.341$345,1986$.

SILVA, F.C. da. Uso agronômico de lodo de esgoto: efeitos em fertilidade do solo e qualidade da cana de açúcar. Piracicaba, 1995. 165 p. Tese (Doutorado) - Escola Superior de Agricultura "Luiz de Queiroz", Universidade de São Paulo. 
SIMS, J.T.; IGO, E.; SKEANS, Y. Comparison of routine soil test and EPA method 3050 as extractants for heavy metals in deleware soils. Communications in Soil Science and Plant Analysis, v.22, n.11/12, p.1031-1045, 1991.

SINGH, B.R.; NARWAL, R.P. Plant availability of heavy metals in a sludge-treated soil: II. Metal extractability compared with plant metal uptake. Journal of Environmental Quality, v. 13, n.3, p.344-349, 1984.

SINGH, B.R.; STEINNES, E. Soil and water contamination by heavy metals. In: LAL, R.; STEWART, B.A. (Ed.) Advances in soil science: soil processes and water quality. Boca Raton: Lewis Publ., 1994. p.233-271.

SINGH, R.S.; SINGH, R.P.; RAI, R.K. Relationship between soil test methods and uptake of copper and zinc by grasses on polluted soils. Communications in Soil Science and Plant Analysis, v.25, n.9/10, p.1313-1320, 1994.

SIQUEIRA, J.O.; FRANCO, A. Biotecnologia do solo: fundamentos e perspectivas. Brasília: MEC; ESAL; FAEPE; ABEAS. 1988. 236p.

SIQUEIRA, J.O.; MOREIRA, E.M.S.; GRISSI, B.M.; HUNGRIA, M.; ARAUJO, R.S. Microrganismos e processos biológicos do solo: prespectiva ambiental. Brasília: EMBRAPA, SPI, 1994. 142p.

SOMMERS, L.E. Chemical composition of swagw sludges and analysis of their potential use as fertilizers. Journal of Environmental Quality, v.6, n.2, p. 225-232, 1977.

SOUZA, G.S. Introdução aos modelos de regressão linear e não linear. Brasília: Embrapa, SPI, SEA, 1998. 489p. 
SOUZA, W.J.O. de; MELO, W.J. de; MARQUES, M.O.; TSUTIYA, M.T. Efeito da aplicação de lodo de esgoto sobre a produção de matéria seca e rendimento de grãos pela cultura do milho em dois tipos de solo. In: SEMINÁRIO SOBRE GERENCIAMENTO DE BIOSSÓLIDOS DO MERCOSUL, 1., Curitiba, 1998. Anais. Curitiba: SANEPAR; ABEAS, 1998. p.313-314.

STEEL, R.G.D.; TORRIE, J.H. Principles and procedures of statistics: with special reference to the biological science. New York: McGraw-Hill, 1960. 48lp.

STEVENSON, F.J. Organic matter reactions involving metal ions in soil. In: STEVENSON, F.J. Humus chemistry: genesis, composition, reactions. New York: John Willey, 1982. p.337-354.

TACKETT, S.L.; WINTERS, E.R.; PUZ, M.J. Leaching of heavy metals from composted sewage sludge as a function of $\mathrm{pH}$. Canadian Journal of Soil Science, v.66, n.4, p.763-765, 1986.

TAN, K.H.; EDWARDS, J.H.; BENNETT, O.L. Effect of sewage on mobilization of surfece-applied calcium in a greenville soil. Soil Science, v.139, n.3, p.262-269, 1985.

TEDESCO, M.J.; GIANELLO, C.; BISSANI, C.A.; BOHENEN, H.; VOLKWEISS, S.L. Análise de solo, plantas e outros materiais. 2.ed. Porto Alegre: UFRGS, Departamento de Solos, 1995. 174p. (Boletim Técnico, 5)

TISDALE, S.L.; NELSON, W.L.; BEATON, J.D. Soil fertility and fertilizers. 4.ed. New York: Macmillan, 1985. 754p. 
USEPA (United States Environmental Protection Agency). 40 CFR Parts 257, 403 and 503. Final rules: standards for the use of sewage sludge. Federal Register,. v.58, n.32, p.9248-9415, 1993

VALADARES, J.M.A.S. Cobre em solos do Estado de São Paulo: I. Cobre total. Bragantia, v.34, n.4, p.125-132, 1975.

VALADARES, J.M.A.S.; CATANI, R.A. Zinco em solos do Estado de São Paulo: I. Zinco total. In: CONGRESSO BRASILEIRO DE CIÊNCIA DO SOLO, 14., Santa Maria, 1974. Anais. Santa Maria: Sociedade Brasileira de Ciência do Solo, 1974. p.291-293.

VICTORIA, R.L.; PICCOLO, M.C.; VARGAS, A.A.T. O ciclo do nitrogênio. In: CARDOSO, E.J.B.N.; TSAI, S.M.; NEVES, M.C.P. (Ed.) Microbiologia do solo. Campinas: Sociedade Brasileira de Ciência do Solo, 1992. cap.8, p.105-119.

VITTI, G.C.; FAVARIN, J.L. Nutrição e manejo químico do solo para a cultura do milho. In: FANCELLI, A.L.; DOURADO-NETO, D. (Coord.) Tecnologia da produção de milho. Piracicaba: Publique, 1997. p. 104-120.

WALLACE, A.; W ALLACE, G.A. A possible flaw in EPA'S 1993 new sludge rule due to heavy metal interactions. Communications in Soil Science and Plant Analysis, v. 25, n.1/2, p.129-135, 1994.

WANG, P.; QU, E., LI, Z. SHUMAN, L.M. Fractions and availability of nickel in loessial soil amended with sewage or sewage sludge. Journal of Environmental Quality, v.26, n.3, p.795-801, 1997. 
WEBBER, M.D. Waste metals: the canadian approach for limiting metals on land from municipal sludges, an update. Sciences et Techniques del'Eau, v.21, n.1, p.41-51, 1988.

WEI, Q.F.; LOWERY,B.; PERTERSON, A.E. Effect of sludge application on physical properties of a silty clay loam soil. Journal of Environmental Quality, v.14, n.2, p.178-180, 1985.

WELCH, J.E.; LUND, L.J. Soil properties, irrigations water quality, and soil moisture level influences on the movement of nickel in sewage sludge-treated soils. Journal of Environmental Quality, v.16, n.4, p.403-410, 1987.

WELCH, J.E.; LUND, L.J. Zinc movement in sewage-sludge-treated soils as influenced by soil properties, irrigation water quality, and soil moisture level. Soil Science, v.147, n.3, p.208-214, 1989.

WILLIAMS, D.E.; VLAMIS, J.; PUKITE, A. H.; COREY, J.E. Metal movement in sludge-amended soils: a nine-year study. Soil Science, v.143, n.2, p.124-131, 1987.

WITTBRODT, P.R.; PALMER, C.D. Reduction of $\mathrm{Cr}$ (VI) by soil humic acids. European Journal of Soil Science, v.47, n.4, p.151-162, 1996. 


\section{APÊNDICE 1}

Análise da variância das variáveis estudadas na água lixiviada, com as devidas transformações e respectivos coeficientes de variação 
Apêndice 1.1 Análise da variância e coeficiente de variação das variáveis quantidade de água lixiviada, $\mathrm{pH}$, condutividade elétrica e quantidades totais lixiviadas de K, Ca e Mg na água durante os períodos de aplicação de biossólido.

\begin{tabular}{|c|c|c|c|c|}
\hline \multirow[t]{2}{*}{ Causas da Variação } & \multirow[t]{2}{*}{ G.L. } & \multicolumn{3}{|c|}{ Q.M. } \\
\hline & & Água lixiviada & $\mathrm{pH}$ & Condutividade elétrica \\
\hline Blocos & 3 & 0,4231 & 0,0000053 & 0,0540 \\
\hline Tratamentos & 3 & $10,7690^{*}$ & $0,0000173^{*}$ & $6,4105^{* *}$ \\
\hline Resíduo (A) & 9 & 1,5407 & 0,0000045 & 0,0309 \\
\hline \multicolumn{5}{|l|}{ (Parcelas) } \\
\hline Aplicações & 4 & $50,9671 * *$ & $0,0000029 * *$ & $3,0182 * *$ \\
\hline Tratamentos x Aplicações & 12 & $2,3014^{* *}$ & $0,0000009 *$ & $0,3968 * *$ \\
\hline Resíduo (B) & 48 & 0,2685 & 0.0000004 & 0,0134 \\
\hline Total & 79 & & & \\
\hline Coef. de var. (A) (\%) & & 6,89 & 5,80 & 1,23 \\
\hline \multirow[t]{2}{*}{ Coef. de var. (B) (\%) } & & 6,41 & 3,87 & 1,81 \\
\hline & & $\mathrm{K}$ & $\mathrm{Ca}$ & $\mathrm{Mg}$ \\
\hline Blocos & 3 & 0,0240 & 0,1940 & 0,2860 \\
\hline Tratamentos & 3 & $4,0702 * *$ & $29,2385^{* *}$ & $8,9332 * *$ \\
\hline Redsíduo (A) & 9 & 0,3184 & 0,1582 & 0,0828 \\
\hline \multicolumn{5}{|l|}{ (Parcelas) } \\
\hline Aplicações & 4 & $4,3220 * *$ & $15,1498 * *$ & $7,3676^{* *}$ \\
\hline Tratamentos * Aplicações & 12 & $0,4730 * *$ & $3,2551^{* *}$ & $1,3573 * *$ \\
\hline Resíduo (B) & 48 & 0,0195 & 0,0201 & 0,0111 \\
\hline Total & 79 & & & \\
\hline Coef. de var. (A) (\%) & & 30,89 & 7,76 & 8,54 \\
\hline Coef. de var. (B) (\%) & & 17,11 & 6,20 & 7,00 \\
\hline
\end{tabular}

$*$ = Significativo, pelo teste $\mathrm{F}$, ao nível de $5 \%(\alpha \leq 0,05)$.

$* *$ = Significativo, pelo teste F. ao nível de $1 \%(\alpha \leq 0.01)$. 
Apêndice 1.2 Desdobramento dos graus de liberdade de Tratamentos em contrastes ortogonais e teste $\mathrm{F}$ dentro de cada Aplicação para as variáveis quantidade de água lixiviada, $\mathrm{pH}$, condutividade elétrica e quantidades totais de $\mathrm{K}$, $\mathrm{Ca}$ e Mg na água lixiviada.

\begin{tabular}{|c|c|c|c|c|c|c|}
\hline \multirow[b]{2}{*}{ Causas da Variação } & \multirow[b]{2}{*}{ G.L } & \multicolumn{5}{|c|}{ Q. M. } \\
\hline & & $1^{\mathrm{a}}$ aplicação & $2^{\mathrm{a} a p l i c a c ̧ a ̃ o ~}$ & $3^{\mathrm{a}}$ aplicação & $4^{a}$ aplicação & $5^{\mathrm{a}}$ aplicação \\
\hline & & \multicolumn{5}{|c|}{ Água lixiviada } \\
\hline Com lodo vs sem lodo & 1 & $0,7140 \mathrm{~ns}$ & $6,4337 \mathrm{~ns}$ & $10,2669 *$ & 0,8789 ns & $34,4627^{* *}$ \\
\hline Com lodo (LV vs LR) & 1 & $1,1893 \mathrm{~ns}$ & $0,0534 \mathrm{~ns}$ & $0,1600 \mathrm{~ns}$ & $0,0575 \mathrm{~ns}$ & $0,0022 \mathrm{~ns}$ \\
\hline Sem lodo (LV vs LR) & 1 & $0,0053 \mathrm{~ns}$ & $1,0642 \mathrm{~ns}$ & $2,4203 \mathrm{~ns}$ & $0,7594 \mathrm{~ns}$ & $1,4565 \mathrm{~ns}$ \\
\hline \multirow[t]{2}{*}{ Resíduo } & 9 & 1,5407 & 1,5407 & 1,5407 & 1.5407 & 1,5407 \\
\hline & & \multicolumn{5}{|c|}{$\mathrm{pH}$} \\
\hline Com lodo vs sem lodo & 1 & $0,0000014 \mathrm{~ns}$ & $0,0000129 \mathrm{~ns}$ & $0,0000085 \mathrm{~ns}$ & $0,000007 \operatorname{lns}$ & $0,0000142 \mathrm{~ns}$ \\
\hline Com lodo (LV vs LR) & 1 & $0,0000001 \mathrm{~ns}$ & $0,0000013 \mathrm{~ns}$ & $0,0000000 \mathrm{~ns}$ & $0,0000000 \mathrm{~ns}$ & $0,0000001 \mathrm{~ns}$ \\
\hline Sem lodo (LV vs LR) & 1 & $0,0000045 \mathrm{~ns}$ & $0,0000067 \mathrm{~ns}$ & $0,0000029 \mathrm{~ns}$ & $0,0000026 \mathrm{~ns}$ & $0,0000001 \mathrm{~ns}$ \\
\hline \multirow[t]{2}{*}{ Resíduo } & 9 & 0.0000045 & 0.0000045 & 0,0000045 & 0,0000045 & 0,0000045 \\
\hline & & \multicolumn{5}{|c|}{ Condutividade elétrica } \\
\hline Com lodo vs sem lodo & 1 & $0,4886^{* *}$ & $1,5220^{* *}$ & $4,2360 * *$ & $7,3865^{* *}$ & $7,6388^{* *}$ \\
\hline Com lodo (LV vs LR) & 1 & $0,8896^{* *}$ & $0,1080 \mathrm{~ns}$ & $0,5915^{* *}$ & $0,5378^{* *}$ & $0,1510 \mathrm{~ns}$ \\
\hline Sem lodo (LV vs LR) & 1 & $0,0176 \mathrm{~ns}$ & $0,0032 \mathrm{~ns}$ & $0,0540 \mathrm{~ns}$ & $0,0712 \mathrm{~ns}$ & $0,2968^{*}$ \\
\hline \multirow[t]{2}{*}{ Resíduo } & 9 & 0,0309 & 0.0309 & 0,0309 & 0.0309 & 0,0309 \\
\hline & & \multicolumn{5}{|c|}{$\mathrm{K}$} \\
\hline Com lodo vs sem lodo & 1 & $0,0106 \mathrm{~ns}$ & $1,5903 \mathrm{~ns}$ & $4,4771^{* *}$ & $2,7111^{*}$ & $7,9796 * *$ \\
\hline Com lodo (LV v's LR) & 1 & $0,0074 \mathrm{~ns}$ & $0,0001 \mathrm{~ns}$ & $0,5084 \mathrm{~ns}$ & $0,0265 \mathrm{~ns}$ & $0,0000 \mathrm{~ns}$ \\
\hline Sem lodo (LV vs LR) & 1 & $0,0640 \mathrm{~ns}$ & $0.0733 \mathrm{~ns}$ & $0,2304 \mathrm{~ns}$ & $0,0340 \mathrm{~ns}$ & $0,1733 \mathrm{~ns}$ \\
\hline \multirow[t]{2}{*}{ Resíduo } & 9 & 0,3184 & 0.3184 & 0.3184 & 0,3184 & 0,3184 \\
\hline & & \multicolumn{5}{|c|}{$\mathrm{Ca}$} \\
\hline Com lodo vs sem lodo & 1 & $0,1400 \mathrm{~ns}$ & $4.2838 * *$ & $30,2649 * *$ & $20,7102^{* *}$ & $56,3902 * *$ \\
\hline Com lodo (LV vs LR) & 1 & $0,2107 \mathrm{~ns}$ & $0,5390 \mathrm{~ns}$ & $6,1158^{* *}$ & $4,3353 * *$ & $3,0414^{* *}$ \\
\hline Sem lodo (LV vs LR) & 1 & $0,0096 \mathrm{~ns}$ & $0,0772 \mathrm{~ns}$ & $0,0470 \mathrm{~ns}$ & $0,1134 \mathrm{~ns}$ & $0,4991 \mathrm{~ns}$ \\
\hline \multirow[t]{2}{*}{ Resíduo } & 9 & 0,1582 & 0.1582 & 0,1582 & 0,1582 & 0,1582 \\
\hline & & \multicolumn{5}{|c|}{$\mathrm{Mg}$} \\
\hline Com lodo vs sem lodo & 1 & $0,0049 \mathrm{~ns}$ & $2,3744^{* *}$ & $14,1075^{* *}$ & $2,8383 * *$ & $19,9140 * *$ \\
\hline Com lodo (LV vs LR) & 1 & $0,0004 \mathrm{~ns}$ & $0.2559 \mathrm{~ns}$ & $2,7703 * *$ & $0,2480 \mathrm{~ns}$ & $0,1670 \mathrm{~ns}$ \\
\hline Sem lodo (LV vs LR) & 1 & $0,0074 \mathrm{~ns}$ & $0,0003 \mathrm{~ns}$ & $0,0020 \mathrm{~ns}$ & $0,0078 \mathrm{~ns}$ & $0,3892 \mathrm{~ns}$ \\
\hline Resíduo & 9 & 0.0828 & 0.0828 & 0,0828 & 0,0828 & 0,0828 \\
\hline
\end{tabular}

$*$ = Significativo, pelo teste $\mathrm{F}$. ao nível de $5 \%((\alpha \leq 0,05)$.

** = Significativo, pelo teste $\mathrm{F}$, ao nível de $1 \%(\alpha \leq 0,01)$.

ns = Não significativo, pelo teste $F$, considerando-se como n.m.s $5 \%(\alpha>0,05)$. 
Apêndice 1.3 Análise da variância e coeficiente de variação para as quantidades totais lixiviadas de $\mathrm{N}_{-} \mathrm{NO}_{3}{ }^{-}$na primeira e na quinta aplicação de biossólido.

\begin{tabular}{lcc}
\hline Causas da Variação & G.L. & Q.M. \\
\hline Blocos & 3 & $\mathrm{~N}^{-\mathrm{NO}_{3}}$ \\
Tratamentos & 3 & 0,1447 \\
Resíduo (A) & 9 & $3,3072^{* *}$ \\
\hline (Parcelas) & $(15)$ & 0,1117 \\
Aplicações & 1 & $21,4702^{* *}$ \\
Tratamentos x Aplicacões & 3 & $2,2132^{* *}$ \\
Resíduo (B) & 12 & 0,0414 \\
\hline Total & 31 & 67,02 \\
\hline Coef. de var. (A) (\%) & 57,66 \\
Coef. de var. (B) (\%) & \\
\hline ** Significativo, pelo teste F, ao nível de $1 \%(\alpha \leq 0,01)$. & \\
\hline
\end{tabular}

Apêndice 1.4 Desdobramento dos graus de liberdade de Tratamentos em contrastes ortogonais e teste $\mathrm{F}$ dentro de cada Aplicação para a variável quantidade de $\mathrm{N}-\mathrm{NO}_{3}{ }^{-}$na água lixiviada.

\begin{tabular}{lccc}
\hline \multicolumn{1}{c}{ Causas da Variação } & G.L. & $1^{\text {a }}$ aplicação & Q.M. \\
\hline Com lodo vs sem lodo & 1 & $0,1260 \mathrm{~ns}$ & $5^{\text {a }}$ aplicação \\
Com lodo (LV vs LR) & 1 & $0,1947 \mathrm{~ns}$ & $0,0002 \mathrm{~ns}$ \\
Sem lodo (LV vs LR) & 1 & $0,0490 \mathrm{~ns}$ & $1,9086^{* *}$ \\
Resíduo & 9 & 0,1117 & 0,1117 \\
\hline
\end{tabular}

** = Significativo, pelo teste $\mathrm{F}$, ao nível de $1 \%(\alpha \leq 0,01)$.

ns = Não significativo. pelo teste F, considerando-se como n.m.s $5 \%(\alpha>0,05)$. 
APÊNDICE 2

Leituras diárias do pluviômetro durante todo o período de duração do experimento 
Apêndice 2.1 Leituras diárias do pluviômetro, expressas em milímetro de chuva, durante o período de monitoramento do ano de 1996.

\begin{tabular}{|c|c|c|c|}
\hline Ano 96 & dia & nov. & dez. \\
\hline \multirow{31}{*}{$(\mathrm{mm})$} & $\mathrm{l}$ & & 0,00 \\
\hline & 2 & & 3,65 \\
\hline & 3 & & 1,76 \\
\hline & 4 & & 0.90 \\
\hline & 5 & & 10,94 \\
\hline & 6 & & 1,05 \\
\hline & 7 & & 0,19 \\
\hline & 8 & & 17,64 \\
\hline & 9 & & 0,00 \\
\hline & 10 & & 0,00 \\
\hline & 11 & & 35,75 \\
\hline & 12 & & 3,52 \\
\hline & 13 & & 3,86 \\
\hline & 14 & & 5,22 \\
\hline & 15 & & 0,00 \\
\hline & 16 & & 0,00 \\
\hline & 17 & & 36,12 \\
\hline & 18 & & 9,11 \\
\hline & 19 & & 0.00 \\
\hline & 20 & & 6,24 \\
\hline & 21 & & 12,05 \\
\hline & 22 & & 0,00 \\
\hline & 23 & $\left({ }^{*}\right)$ & 47,58 \\
\hline & 24 & 0,00 & 0,43 \\
\hline & 25 & 0,00 & 0,71 \\
\hline & 26 & 0,00 & 0,00 \\
\hline & 27 & 0,00 & 0.00 \\
\hline & 28 & 0,00 & 6,12 \\
\hline & 29 & 0,00 & 15,70 \\
\hline & 30 & 0,00 & 0,00 \\
\hline & 31 & & 0.00 \\
\hline total & & 0,00 & 218.54 \\
\hline \multirow[t]{2}{*}{ média } & & 0.00 & 7,05 \\
\hline & & $=$ & \\
\hline
\end{tabular}

$\left(^{*}\right)$ Primeira aplicação de lodo. 
Apêndice 2.2 Leituras diárias do pluviômetro, expressas em milímetro de chuva, durante o período de monitoramento de janeiro a maio de 1997.

\begin{tabular}{|c|c|c|c|c|c|c|}
\hline Ano 97 & dia & jan. & fev. & mar. & abr. & maio \\
\hline \multirow[t]{31}{*}{$(\mathrm{mm})$} & 1 & 0,00 & 29,72 & 0,00 & 19,53 & 0,00 \\
\hline & 2 & 0,46 & 1,08 & 0,00 & 0,00 & 0,00 \\
\hline & 3 & 0,00 & 17,09 & 0,00 & 3,43 & 0,00 \\
\hline & 4 & 0,00 & 0,22 & 3,18 & 0,00 & 0,00 \\
\hline & 5 & 0,00 & 0,00 & 1,73 & 0,07 & 0,00 \\
\hline & 6 & 0,00 & 0,00 & 14,77 & 0,00 & 0,00 \\
\hline & 7 & 0,34 & 0,00 & 0,00 & 0,00 & 0,00 \\
\hline & 8 & 2,47 & $0,00\left(^{*}\right)$ & 0,00 & 0,00 & 0,00 \\
\hline & 9 & 13,53 & 0,00 & 0,00 & 0,00 & 0,00 \\
\hline & 10 & 1,36 & 3,99 & 0,00 & 0,00 & 0,00 \\
\hline & 11 & 21,23 & 0,00 & 0,00 & $0,00\left(^{* *}\right)$ & 0,00 \\
\hline & 12 & 5,62 & 0,00 & 0,00 & 0,00 & 0,00 \\
\hline & 13 & 10,66 & 17,73 & 0,03 & 0,00 & 0,00 \\
\hline & 14 & 2,60 & 2,13 & 26,60 & 0,00 & 0,00 \\
\hline & 15 & 2,50 & 3,83 & 0,00 & 0,00 & 0,00 \\
\hline & 16 & 0,31 & 3,46 & 3,24 & 0,00 & 0,87 \\
\hline & 17 & 0,00 & 33,59 & 0,00 & 0,00 & 0,21 \\
\hline & 18 & 14,03 & 11,65 & 0,00 & 26,17 & 0,00 \\
\hline & 19 & 0,00 & 0,03 & 0,00 & 0,00 & 0,00 \\
\hline & 20 & 29,75 & 0,00 & 0,00 & 0,00 & 0,00 \\
\hline & 21 & 12,79 & 2,60 & 0,00 & 2,81 & 0,00 \\
\hline & 22 & 0,31 & 0,65 & 0,00 & 0,00 & 1,61 \\
\hline & 23 & 25,83 & 0,00 & 0,00 & 0,00 & 4,20 \\
\hline & 24 & 12,30 & 2,32 & 0,00 & 0,00 & 0,00 \\
\hline & 25 & 34,60 & 0,00 & 0,00 & 0,00 & 34,88 \\
\hline & 26 & 0,00 & 0,00 & 0,00 & 0,00 & 0,03 \\
\hline & 27 & 17,81 & 0,00 & 0,00 & 0,00 & 0,00 \\
\hline & 28 & 48,26 & 0,00 & 0,00 & 0,00 & 9,15 \\
\hline & 29 & 31,45 & & 0,00 & 0,00 & 2,35 \\
\hline & 30 & 0,00 & & 0,00 & 0,00 & 0,00 \\
\hline & 31 & 10,06 & & 0,32 & & 0,00 \\
\hline & 298.28 & 130,08 & 49,88 & 52,02 & 53,29 \\
\hline \multirow{2}{*}{\multicolumn{2}{|c|}{ média }} & 9,62 & 4,65 & 1,61 & 1,73 & 1,72 \\
\hline & & & OTAL PI & $=$ & 583,55 & $\mathrm{~mm}$ \\
\hline
\end{tabular}

$\left.{ }^{*}\right)$ Segunda aplicação de lodo.

$\left.{ }^{* *}\right)$ Terceira aplicação de lodo. 
Apêndice 2.3 Leituras diárias do pluviômetro, expressas em milímetro de chuva, durante o período de monitoramento de junho a outubro de 1997.

\begin{tabular}{|c|c|c|c|c|c|c|}
\hline Ano 97 & dia & jun. & jul. & ago. & set. & out. \\
\hline \multirow[t]{31}{*}{$(\mathrm{mm})$} & 1 & 0,00 & 0,00 & 0,00 & 0,00 & 15,39 \\
\hline & 2 & 0,00 & 0,00 & 0,00 & 0,00 & 2,44 \\
\hline & 3 & 0,00 & 0,00 & 0,00 & 0,00 & 0,00 \\
\hline & 4 & 5,16 & 0,00 & 0,00 & 0,00 & 0,00 \\
\hline & 5 & 47,03 & 0,00 & 0,00 & 0,00 & 0,00 \\
\hline & 6 & 20,18 & 0,00 & 0,39 & 1,67 & $0,02(* * *)$ \\
\hline & 7 & 0,00 & 0,00 & 0,01 & 0,00 & 5,87 \\
\hline & 8 & 0,00 & 0,00 & 0,01 & 0,00 & 0,00 \\
\hline & 9 & 0,00 & 0,00 & 0,12 & 0,00 & 0,00 \\
\hline & 10 & 0,03 & 0,00 & 0,00 & 0,00 & 0,00 \\
\hline & 11 & 0,00 & 0,00 & 0,00 & 0,00 & 0,00 \\
\hline & 12 & 10,81 & 0,00 & 0,00 & 0,00 & 0,00 \\
\hline & 13 & $0,00\left(^{*}\right)$ & 0,01 & 0,00 & 0,00 & 0,00 \\
\hline & 14 & 0,00 & 0,00 & 0,00 & 16,87 & 0,00 \\
\hline & 15 & 16,53 & 0,00 & 0,00 & 18,04 & 0,00 \\
\hline & 16 & 9,27 & 0,00 & $0,00(* *)$ & 1,36 & 4,76 \\
\hline & 17 & 0,00 & 0,00 & 0,00 & 0,00 & 3,24 \\
\hline & 18 & 0,00 & 0,00 & 0,00 & 0,00 & 0,00 \\
\hline & 19 & 0,00 & 0,03 & 0,00 & 0,00 & 1,02 \\
\hline & 20 & 0,62 & 0,00 & 0,00 & 0,00 & 2,50 \\
\hline & 21 & 7.20 & 8,84 & 0,00 & 26,48 & 16,41 \\
\hline & 22 & 0,00 & 10,26 & 0,00 & 0,09 & 0,04 \\
\hline & 23 & 0,00 & 0,00 & 0,00 & 0,00 & 0.00 \\
\hline & 24 & 0,00 & 0,00 & 17,86 & 0,00 & 0,00 \\
\hline & 25 & 0,00 & $\bullet, 00$ & 0,00 & 0,71 & 0,00 \\
\hline & 26 & 0,00 & 0,00 & 0,00 & 15,54 & 5,04 \\
\hline & 27 & 0,00 & 0,00 & 0,00 & 0,00 & 6,36 \\
\hline & 28 & 0,00 & 0,00 & 0,00 & 0,00 & 0,00 \\
\hline & 29 & 0.21 & 0,00 & 0,00 & 0,00 & 0,00 \\
\hline & 30 & 0,00 & 0,00 & 0,00 & 15,11 & 0,00 \\
\hline & 31 & & 0,00 & 0,00 & & 3,86 \\
\hline \multirow{3}{*}{\multicolumn{2}{|c|}{$\begin{array}{l}\text { total } \\
\text { média }\end{array}$}} & 117,07 & 19,14 & 18,39 & 95,87 & 66,95 \\
\hline & & 3,90 & 0,62 & 0,59 & 3,20 & 2,16 \\
\hline & & & TAL PE & $\mathrm{O}=$ & 317,39 & $\mathrm{~mm}$ \\
\hline
\end{tabular}

(*) Quarta aplicação de lodo.

$\left({ }^{* *}\right)$ Quinta aplicação de lodo.

$\left.{ }^{* * *}\right)$ Início do horário de verão. 
Apêndice 2.4 Leituras diárias do pluviômetro, expressas em milímetro de chuva, durante o periodo de monitoramento de novembro a dezembro de 1997.

\begin{tabular}{|c|c|c|c|}
\hline Ano 97 & dia & nov. & dez. \\
\hline \multirow[t]{34}{*}{$(\mathrm{mm})$} & 1 & 0,00 & 0.00 \\
\hline & 2 & 22,18 & 4.70 \\
\hline & 3 & 1,76 & 11,93 \\
\hline & 4 & 0,00 & 16.53 \\
\hline & 5 & 0,00 & 9.08 \\
\hline & 6 & 0,00 & 0,00 \\
\hline & 7 & 3,99 & 0,00 \\
\hline & 8 & 0,40 & 31,64 \\
\hline & 9 & 0,00 & 0,00 \\
\hline & 10 & $0,00\left(^{*}\right)$ & 0,00 \\
\hline & 11 & 0,00 & 0,00 \\
\hline & 12 & 4,20 & 0,00 \\
\hline & 13 & 0.00 & 0,00 \\
\hline & 14 & 7,60 & 1,73 \\
\hline & 15 & 22,49 & 19,16 \\
\hline & 16 & 1,88 & 0,00 \\
\hline & 17 & 35,59 & 0,00 \\
\hline & 18 & 18,17 & 0,00 \\
\hline & 19 & 25,61 & 0,56 \\
\hline & 20 & 0,00 & 4,94 \\
\hline & 21 & 0,00 & 0,00 \\
\hline & 22 & 6,92 & 10,81 \\
\hline & 23 & 5,78 & 0,00 \\
\hline & 24 & 11,74 & 0,00 \\
\hline & 25 & 41,59 & 68.59 \\
\hline & 26 & 0,19 & 6.55 \\
\hline & 27 & 24,10 & 0,00 \\
\hline & 28 & 26,02 & 0,00 \\
\hline & 29 & 0.34 & 0.00 \\
\hline & 30 & 0,00 & 0,00 \\
\hline & 31 & & 0.00 \\
\hline & total & 260.56 & 186.22 \\
\hline & \multirow[t]{2}{*}{ média } & 8.69 & 6.01 \\
\hline & & $=$ & \\
\hline
\end{tabular}

(*) Aplicou-se $8 \mathrm{~L}$ de água/caixa $\left(\mathrm{dl}=1,06 \mathrm{~m} . \mathrm{rl}=0,53 \mathrm{~m}, \mathrm{~h}=0,65 \mathrm{~m}\right.$, Area $\left.=0,8825 \mathrm{~m}^{2}, \mathrm{~d} 2=0,90 \mathrm{~m}\right)$. 
Apêndice 2.5 Leituras diárias do pluviômetro, expressas em milímetro de chuva, durante o periodo de monitoramento do ano de 1998.

\begin{tabular}{|c|c|c|c|}
\hline Ano 98 & dia & jan. & fev. \\
\hline \multirow[t]{31}{*}{$(\mathrm{mm})$} & 1 & 0,00 & 0,03 \\
\hline & 2 & 0,00 & 4,20 \\
\hline & 3 & 0,00 & $0,00\left(^{* * *}\right)$ \\
\hline & 4 & 4,08 & 0,00 \\
\hline & 5 & $0,00(* * *)$ & 40,54 \\
\hline & 6 & $0,00(* * *)$ & 10,94 \\
\hline & 7 & 0,00 & 0,00 \\
\hline & 8 & 10,94 & 0,87 \\
\hline & 9 & 3,06 & 0,03 \\
\hline & 10 & 0,65 & 0,00 \\
\hline & 11 & 0,00 & 20,52 \\
\hline & 12 & 0,00 & 15.39 \\
\hline & 13 & 5,50 & 5,13 \\
\hline & 14 & 0,06 & 46,04 \\
\hline & 15 & $0,00(* * *)$ & 5,47 \\
\hline & 16 & 12,05 & 65,50 \\
\hline & 17 & 5,31 & 0,99 \\
\hline & 18 & 57,16 & 0,00 \\
\hline & 19 & 0,00 & $0,00\left(^{* *}\right)$ \\
\hline & 20 & 0,00 & \\
\hline & 21 & 1,48 & \\
\hline & 22 & 0,00 & \\
\hline & 23 & 0,00 & \\
\hline & 24 & 0,00 & \\
\hline & 25 & 3,03 & \\
\hline & 26 & 25,03 & \\
\hline & 27 & 0,00 & \\
\hline & 28 & 0,00 & \\
\hline & 29 & 8,10 & \\
\hline & 30 & $0,00\left(^{*}\right)$ & \\
\hline & 31 & $0,00(* * *)$ & \\
\hline total & & 136.44 & 215,63 \\
\hline média & & 4,40 & 11,35 \\
\hline & & $\mathrm{DO}=$ & $\mathrm{mm}$ \\
\hline
\end{tabular}

$\left({ }^{*}\right)$ Colheita do milho dos ratamentos LV-test e LR-test.

$\left.{ }^{* *}\right)$ Colheita do milho dos ratamentos LV+lodo e LR+lodo.

$\left(^{* * *}\right)$ Aplicou-se $8 \mathrm{~L}$ de água/caixa. 


\section{APÊNDICE 3}

Análise da variância das variáveis estudadas no solo, com as devidas transformações e respectivos coeficientes de variação 
Apêndice 3.1 Análise da variância e coeficiente de variação das variáveis condutividade elétrica, $\mathrm{pH}$ e teores de $\mathrm{K}, \mathrm{Ca}, \mathrm{Mg}$ durante os períodos de aplicação de biossólido.

\begin{tabular}{|c|c|c|c|c|}
\hline \multirow[t]{2}{*}{ Causas da Variação } & \multirow[t]{2}{*}{ G.L. } & \multicolumn{3}{|c|}{ Q.M. } \\
\hline & & $\mathrm{pHCaCl} 20,01 \mathrm{~mol} \mathrm{~L}^{-1}$ & Condutividade elétrica & $\bar{K}$ \\
\hline Blocos & 3 & 0,0754 & 0,0356 & 0,0481 \\
\hline Tratamentos & 3 & $32,4004 * *$ & $27,7356^{* *}$ & $1,3007 * *$ \\
\hline Resíduo (A) & 9 & 0,0307 & 0,0082 & 0,0822 \\
\hline \multicolumn{5}{|c|}{ (Parcelas) } \\
\hline Aplicações & 4 & $1,6895 * *$ & $1,5058 * *$ & $0,014 \operatorname{lns}$ \\
\hline Tratamentos x Aplicações & 12 & $0,2884^{* *}$ & $0,4549 * *$ & $0,0644 \mathrm{~ns}$ \\
\hline Residuo (B) & 48 & $0,0124^{* *}$ & 0,0153 & 0,0638 \\
\hline Total & 79 & & & \\
\hline Coef. de var. (A) (\%) & & 1,39 & 0,76 & 11,59 \\
\hline \multirow[t]{2}{*}{ Coef. de var. (B) (\%) } & & 1,97 & 2,30 & 22,84 \\
\hline & & $\overline{\mathrm{Ca}}$ & $\mathrm{Mg}$ & \\
\hline Blocos & 3 & 11,0895 & 1,9923 & \\
\hline Tratamentos & 3 & $2.8176,93^{* *}$ & $33,7297 * *$ & \\
\hline Redsíduo (A) & 9 & 48,9432 & 1,1644 & \\
\hline \multicolumn{5}{|c|}{ (Parcelas) } \\
\hline Aplicações & 4 & $958,5635^{* *}$ & $5,9764^{* *}$ & \\
\hline Tratamentos x Aplicações & 12 & $495,5416^{* *}$ & $0,6656^{* *}$ & \\
\hline Resíduo (B) & 48 & 16,1045 & 0,1813 & \\
\hline Total & 79 & & & \\
\hline Coef. de var. (A) (\%) & & 7,58 & 12,82 & \\
\hline Coef. de var. (B) (\%) & & 9,72 & 11,31 & \\
\hline
\end{tabular}

* = Significativo, pelo teste $\mathrm{F}$, ao nível de $5 \%(\alpha \leq 0,05)$.

** = Significativo, pelo teste $F$, ao nível de $1 \%(\alpha \leq 0,01)$.

ns = Não significativo. pelo teste F, considerando-se como n.m.s. $5 \%(\alpha>0,05)$. 
Apêndice 3.2 Desdobramento dos graus de liberdade de Tratamentos em contrastes ortogonais e teste $\mathrm{F}$ dentro de cada Aplicação para as variáveis, $\mathrm{pH}$, condutividade elétrica, $\mathrm{K}, \mathrm{Ca}$ e $\mathrm{Mg}$, referentes ao solo.

\begin{tabular}{|c|c|c|c|c|c|c|}
\hline \multirow[b]{2}{*}{ Causas da Variação } & \multirow[b]{2}{*}{ G.L } & \multicolumn{5}{|c|}{ Q. M. } \\
\hline & & $1^{\mathrm{a}}$ aplicação & $2^{a}$ aplicação & $3^{\mathrm{a}}$ aplicação & $4^{a}$ aplicação & $5^{\text {a }}$ aplicaçào \\
\hline & & \multicolumn{5}{|c|}{$\mathrm{pH}$} \\
\hline Com lodo vs sem lodo & 1 & $8,4100^{* *}$ & $18,5976^{* *}$ & $21,1600^{* *}$ & $25,8826^{* *}$ & $26,0100^{* *}$ \\
\hline Com lodo (LV vs LR) & 1 & $0,0800 \mathrm{~ns}$ & $0,3003 *$ & $0,0200 \mathrm{~ns}$ & $0,0200 \mathrm{~ns}$ & $0,0312 \mathrm{~ns}$ \\
\hline Sem lodo (LV vs LR) & 1 & $0,0800 \mathrm{~ns}$ & $0,0050 \mathrm{~ns}$ & $0,0450 \mathrm{~ns}$ & $0,0003 \mathrm{~ns}$ & $0,0200 \mathrm{~ns}$ \\
\hline \multirow[t]{2}{*}{ Resíduo } & 9 & 0,0307 & 0,0307 & 0,0307 & 0,0307 & 0,0307 \\
\hline & & \multicolumn{5}{|c|}{ Condutividade elérica } \\
\hline Com lodo vs sem lodo & 1 & $5,8510^{* *}$ & $9.6108^{* *}$ & $17,5897^{* *}$ & $23,3687 * *$ & $26,2620^{* *}$ \\
\hline Com lodo (LV vs LR) & 1 & $0,2290 * *$ & $0,1029 * *$ & $0,4317 * *$ & $0,2252 * *$ & $0,1220 * *$ \\
\hline Sem lodo (LV vs LR) & 1 & $0,8096^{* *}$ & $0,5846^{* *}$ & $1,0348^{* *}$ & $1,4303 * *$ & $1,0132 * *$ \\
\hline \multirow[t]{2}{*}{ Resíduo } & 9 & 0,0082 & 0,0082 & 0,0082 & 0,0082 & 0,0082 \\
\hline & & \multicolumn{5}{|c|}{$\bar{K}$} \\
\hline Com lodo vs sem lodo & 1 & \multicolumn{5}{|c|}{$0,7401^{*}$} \\
\hline Com lodo (LV vs LR) & 1 & \multicolumn{5}{|c|}{$2,0433 * *$} \\
\hline Sem lodo (LV vs LR) & 1 & \multicolumn{5}{|c|}{$1,1188^{* *}$} \\
\hline Resíduo & 9 & \multicolumn{5}{|c|}{0,0822} \\
\hline & & \multicolumn{5}{|c|}{$\mathrm{Ca}$} \\
\hline Com lodo vs sem lodo & 1 & $4.329 .64^{* *}$ & $7.365,93^{* *}$ & $10.085,18^{* *}$ & $17.802,23^{* *}$ & $20.721,60^{* *}$ \\
\hline Com lodo (LV vs LR) & 1 & $3.676,53^{* *}$ & $2.861,46^{* *}$ & $3.745,45^{* *}$ & $8.508,60^{* *}$ & $9.604,98^{* *}$ \\
\hline Sem lodo (LV vs LR) & 1 & $556,11^{* *}$ & $292,82 *$ & $297,68^{*}$ & $345,84^{*}$ & $283,22 *$ \\
\hline \multirow[t]{2}{*}{ Resíduo } & 9 & 48,94 & 48,94 & 48,94 & 48,94 & 48,94 \\
\hline & & \multicolumn{5}{|c|}{$\mathrm{Mg}$} \\
\hline Com lodo vs sem lodo & 1 & $2,8056 \mathrm{~ns}$ & $0,3600 \mathrm{~ns}$ & $0,4225 \mathrm{~ns}$ & $0,2025 \mathrm{~ns}$ & $0,6806 \mathrm{~ns}$ \\
\hline Com lodo (LV vs LR) & 1 & $23,8050^{* *}$ & $8.2012^{*}$ & $10,3512 *$ & $9,0312 *$ & $20,4800^{* *}$ \\
\hline Sem lodo (LV vs LR) & 1 & $11,7612^{*}$ & $3,7812 \mathrm{~ns}$ & $5,6112 \mathrm{~ns}$ & $7,0312 \mathrm{~ns}$ & $4,6512 \mathrm{~ns}$ \\
\hline Resíduo & 9 & 1,1644 & 1.1644 & 1,1644 & 1,1644 & 1,1644 \\
\hline
\end{tabular}

$*$ = Significativo, pelo teste $\mathrm{F}$, ao nível de $5 \%((\alpha \leq 0,05)$.

** = Significativo. pelo teste $\mathrm{F}$, ao nível de $1 \%(\alpha \leq 0,01)$.

ns = Não significativo, pelo teste F, considerando-se como n.m.s $5 \%(\alpha>0,05)$. 
Apêndice 3.3 Análise da variância e coeficiente de variação para os teores $\mathrm{Cd}$, $\mathrm{Cr}$ e $\mathrm{Ni}$ removidos pelos diversos métodos de extração.

\begin{tabular}{lcccc}
\hline \multicolumn{1}{c}{ Causas de Variação } & G.L. & \multicolumn{3}{c}{ Q.M. } \\
\hline Blocos & & $\mathrm{Cd}$ & $\mathrm{Cr}$ & $\mathrm{Ni}$ \\
Tratamentos & 3 & 0,1218 & 1,0286 & 10,4048 \\
Métodos & 1 & $0,5552 \mathrm{~ns}$ & $4,1407^{*}$ & $71,4903^{* *}$ \\
Tratamentos x Métodos & 3 & $4,8478^{* *}$ & $182,6211^{* *}$ & $2.479,4685^{* *}$ \\
Resíduo & 21 & $0,5916 \mathrm{~ns}$ & $25,3845^{* *}$ & $408,9806^{* *}$ \\
\hline Total & 31 & 0,2572 & 0,8385 & 4,7487 \\
\hline Coef. de variação (\%) & & & & \\
\hline
\end{tabular}

$*$ = Significativo, pelo teste $\mathrm{F}$, ao nível de $5 \%(\alpha \leq 0,05)$.

** = Significativo, pelo teste $\mathrm{F}$, ao nível de $1 \%(\alpha \leq 0,01)$.

ns $=$ Não significativo, pelo teste $F$, considerando-se como n.m.s $5 \%(\alpha>0,05)$.

Apêndice 3.4 Análise da variância e coeficiente de variação para os teores $\mathrm{Cu}$, Mn e $\mathrm{Zn}$ removidos pelos diversos métodos de extração.

\begin{tabular}{lcccc}
\hline \multicolumn{1}{c}{ Causas de Variação } & G.L. & \multicolumn{3}{c}{ Q.M. } \\
\hline & & $\mathrm{Cu}$ & $\mathrm{Mn}$ & $\mathrm{Zn}$ \\
\cline { 2 - 5 } Blocos & 3 & 0,0087 & 2,0965 & 0,2610 \\
Tratamentos & 3 & $22,1377^{* *}$ & $332,6536^{* *}$ & $275,7643^{* *}$ \\
Métodos & 3 & $12,3495^{* *}$ & $349,4546^{* *}$ & $103,2684^{* *}$ \\
Tratamentos x Métodos & 9 & $2,1596^{* *}$ & $46,2180^{* *}$ & $24,5934^{* *}$ \\
Resíduo & 45 & 0,0068 & 1,7617 & 0,1418 \\
\hline Total & 63 & & & \\
\hline Coef. de variação (\%) & & 3,74 & 18,05 & 6,77 \\
\hline
\end{tabular}

** = Significativo, pelo teste $\mathrm{F}$, ao nível de $1 \%(\alpha \leq 0,01)$. 
Apêndice 3.5 Desdobramento dos graus de liberdade de Tratamentos em contrastes ortogonais e teste $\mathrm{F}$ dentro de cada Método para as variáveis teores de $\mathrm{Cu}$, Mn e $\mathrm{Zn}$ nas amostras de terra.

\begin{tabular}{|c|c|c|c|c|c|}
\hline \multirow[b]{2}{*}{ Causas da Variação } & \multirow[b]{2}{*}{ G.L. } & \multicolumn{4}{|c|}{ Q.M. } \\
\hline & & $\mathrm{HCl} 0,1 \mathrm{~mol} \mathrm{~L}^{-1}$ & Mehlich 3 & DTPA & Agua régia \\
\hline & & \multicolumn{4}{|c|}{$\mathrm{Cu}$} \\
\hline Com lodo vs sem lodo & 1 & $3,2730^{* *}$ & $21,1607^{* *}$ & $19,2899^{* *}$ & $16,1560^{* *}$ \\
\hline Com lodo (LV vs LR) & 1 & $9,4774 * *$ & $0,5200 * *$ & $0,6272 * *$ & $1,5009^{* *}$ \\
\hline Sem lodo (LV vs LR) & 1 & $1,5175^{* *}$ & $1,6914 * *$ & $1,4756^{* *}$ & $9,1603 * *$ \\
\hline \multirow[t]{2}{*}{ Resíduo } & 45 & 0,0068 & 0,0068 & 0,0068 & 0,0068 \\
\hline & & \multicolumn{4}{|c|}{$\mathrm{Mn}$} \\
\hline Com lodo vs sem lodo & 1 & $2,367 \operatorname{lns}$ & $0,06598 \mathrm{~ns}$ & $15,6744^{* *}$ & $4,172 \operatorname{lns}$ \\
\hline Com lodo (LV vs LR) & 1 & $2,3874 \mathrm{~ns}$ & $18,3301^{* *}$ & $12,5166^{*}$ & $338,3635^{* *}$ \\
\hline Sem lodo (LV vs LR) & 1 & $117,8619^{* *}$ & $79,9392 * *$ & $88,3441^{* *}$ & $733,9007 * *$ \\
\hline \multirow[t]{2}{*}{ Resíduo } & 45 & 1,7617 & 1,7617 & 1,7617 & 1,7617 \\
\hline & & \multicolumn{4}{|c|}{$\mathrm{Zn}$} \\
\hline Com lodo vs sem lodo & 1 & $148,8727^{* *}$ & $188,8275^{* *}$ & $92,7227^{* *}$ & $464,0124^{* *}$ \\
\hline Com lodo (LV vs LR) & 1 & $63,7835^{* *}$ & $2,8365^{* *}$ & $9,3927 * *$ & $59,6616^{* *}$ \\
\hline Sem lodo (LV vs LR) & 1 & $0,2440 \mathrm{~ns}$ & $0,1415 \mathrm{~ns}$ & $0,0067 \mathrm{~ns}$ & $18,1320 * *$ \\
\hline Resíduo & 45 & 0,1418 & 0,1418 & 0,1418 & 0,1418 \\
\hline
\end{tabular}

$*$ = Significativo. pelo teste $F$, ao nivel de $5 \%(\alpha \leq 0,05)$.

** = Significativo. pelo teste $\mathrm{F}$, ao nível de $1 \%(\alpha \leq 0,01)$.

ns $=$ Não significativo, pelo teste $F$, considerando-se como n.m.s $5 \%(\alpha>0,05)$. 


\section{APÊNDICE 4}

Teores e quantidades absorvidas de metais e análise da variância das variáveis estudadas na planta, com as devidas transformações e respectivos coeficientes de variação 
Apêndice 4.1 Teores de metais, em $\mathrm{mg} \mathrm{kg}^{-1}$ de matéria seca, encontrados nas diversas partes da planta de milho em função das aplicações de biossólido. Valores médios de quatro repetições.

\begin{tabular}{|c|c|c|c|c|}
\hline \multirow[t]{2}{*}{ Partes da planta } & \multicolumn{4}{|c|}{ Tratamentos } \\
\hline & LV+lodo & LV & LR+lodo & LR \\
\hline & & & & \\
\hline \multirow[t]{2}{*}{ Sabugo } & 1,17 & 0,94 & 1,33 & 1,85 \\
\hline & \multicolumn{4}{|c|}{$\mathrm{Cu}$} \\
\hline Grão & 2,76 & 2,37 & 2,80 & 2,46 \\
\hline Bainha & 5,44 & 2,09 & 6,01 & 2.65 \\
\hline Colmo & 4,51 & 1,21 & 5,19 & 2,30 \\
\hline Palha da espiga & 5,51 & 1,82 & 5,52 & 2,95 \\
\hline Sabugo & 4,18 & 2,04 & 4,44 & 3,39 \\
\hline Folha diagnose (FD) & 14,26 & 6,36 & 14,73 & 12,02 \\
\hline \multirow[t]{2}{*}{$\begin{array}{c}\text { Folhas ao final do ciclo } \\
\text { da cultura (FF) }\end{array}$} & 10,32 & 4,32 & 13,12 & 8,81 \\
\hline & \multicolumn{4}{|c|}{$\mathrm{Mn}$} \\
\hline Grão & 9,30 & 9,29 & 10,47 & 10,26 \\
\hline Bainha & 23,88 & 73,54 & 63,44 & 107,88 \\
\hline Colmo & 3,53 & 9,73 & 8,34 & 13,64 \\
\hline Palha da espiga & 7,60 & 10,79 & 16,26 & 16,52 \\
\hline Sabugo & 7,19 & 7,58 & 11,96 & 9,35 \\
\hline Folha diagnose (FD) & 22,79 & 27,46 & 64,71 & 50.16 \\
\hline \multirow[t]{2}{*}{$\begin{array}{c}\text { Folhas ao final do ciclo } \\
\text { da cultura (FF) }\end{array}$} & 24,86 & 44,01 & 119,92 & 92,99 \\
\hline & \multicolumn{4}{|c|}{$\mathrm{Zn}$} \\
\hline Grão & 53,23 & 42,53 & 45,54 & 38,17 \\
\hline Bainha & 27,24 & 9,32 & 21,73 & 4,97 \\
\hline Colmo & 41,38 & 10,70 & 35,89 & 8,16 \\
\hline Palha da espiga & 74,72 & 17,11 & 55,91 & 10,30 \\
\hline Sabugo & 85,69 & 16,66 & 93,86 & 14.05 \\
\hline Folha diagnose (FD) & 33,43 & 17,91 & 28,36 & 14.99 \\
\hline $\begin{array}{l}\text { Folhas ao final do ciclo } \\
\text { da cultura (FF) }\end{array}$ & 40,59 & 11,55 & 37,46 & 10,09 \\
\hline
\end{tabular}


Apêndice 4.2 Quantidades absorvidas, em $\mathrm{mg} \mathrm{vaso}^{-1}$, encontradas nas diversas partes da planta de milho em função das aplicações de biossólido. Valores médios de quatro repetições.

\begin{tabular}{|c|c|c|c|c|}
\hline \multirow[t]{2}{*}{ Partes da planta } & \multicolumn{4}{|c|}{ Tratamentos } \\
\hline & LV+lodo & $\mathrm{LV}$ & LR+lodo & LR \\
\hline & & & & \\
\hline \multirow[t]{2}{*}{ Sabugo } & 0,03 & 0,02 & 0,02 & 0,04 \\
\hline & \multicolumn{4}{|c|}{$\mathrm{Cu}$} \\
\hline Grão & 0,27 & 0,20 & 0,18 & 0,20 \\
\hline Bainha & 0,15 & 0,05 & 0,15 & 0,06 \\
\hline Colmo & 0,41 & 0,09 & 0,51 & 0,14 \\
\hline Palha da espiga & 0,01 & 0,002 & 0,01 & 0,003 \\
\hline Sabugo & 0,08 & 0,05 & 0,07 & 0,07 \\
\hline Folha diagnose (FD) & 0,03 & 0,01 & 0,03 & 0,02 \\
\hline \multirow[t]{2}{*}{$\begin{array}{l}\text { Folhas ao final do ciclo } \\
\text { da cultura (FF) }\end{array}$} & 0,50 & 0,18 & 0,58 & 0,39 \\
\hline & \multicolumn{4}{|c|}{ Mn } \\
\hline Grão & 0,91 & 0,79 & 0,68 & 0,80 \\
\hline Bainha & 0,64 & 1,78 & 1,58 & 2,49 \\
\hline Colmo & 0,34 & 0,70 & 0,84 & 0,87 \\
\hline Palha da espiga & 0,19 & 0,24 & 0,41 & 0,32 \\
\hline Sabugo & 0,13 & 0,18 & 0,18 & 0,19 \\
\hline Folha diagnose (FD) & 0,05 & 0,04 & 0,13 & 0,08 \\
\hline \multirow[t]{2}{*}{$\begin{array}{l}\text { Folhas ao final do ciclo } \\
\text { da cultura (FF) }\end{array}$} & 1,23 & 1,83 & 5,33 & 4,11 \\
\hline & \multicolumn{4}{|c|}{$\mathrm{Zn}$} \\
\hline Grão & 5,28 & 3,59 & 3,04 & 3,00 \\
\hline Bainha & 0,73 & 0,23 & 0,55 & 0,11 \\
\hline Colmo & 3,85 & 0,76 & 3,67 & 0,51 \\
\hline Palha da espiga & 1,86 & 0,39 & 1,36 & 0,20 \\
\hline Sabugo & 1,68 & 0,40 & 1,36 & 0,29 \\
\hline Folha diagnose (FD) & 0,08 & 0,03 & 0,06 & 0,02 \\
\hline $\begin{array}{l}\text { Folhas ao final do ciclo } \\
\text { da cultura (FF) }\end{array}$ & 2,02 & 0,49 & 1,69 & 0,45 \\
\hline
\end{tabular}


Apêndice 4.3 Análise da variância e coeficiente de variação para as variáveis teores e quantidades de $\mathrm{Cr}$ e $\mathrm{Cu}$ nas diversas partes da planta de milho e teores e quantidades de Mn na bainha, colmo, FD e FF.

\begin{tabular}{|c|c|c|c|c|c|c|c|}
\hline \multirow[t]{3}{*}{ Causas de Variação } & \multirow[t]{3}{*}{ G.L. } & \multicolumn{6}{|c|}{ Q.M. } \\
\hline & & \multicolumn{2}{|c|}{$\underline{\mathrm{Cr} \text {-sabugo }}$} & \multicolumn{2}{|c|}{ Cu-bainha } & \multicolumn{2}{|c|}{ Cu-colmo } \\
\hline & & teor & quant.abs & teor & quant.abs. & teor & quant.abs \\
\hline Blocos & 3 & 0,2701 & 427 & 0,0043 & 151 & 0,0175 & 0,0125 \\
\hline Tratamentos & 3 & $2,4149 * *$ & $1.180^{*}$ & $0,8270^{* *}$ & $45.247 * *$ & $0,6379 * *$ & $2,0808^{* *}$ \\
\hline Resíduo & 9 & 0.3048 & 230 & 0,0052 & 710 & 0,0133 & 0,0097 \\
\hline Total & 15 & & & & & & \\
\hline \multirow[t]{3}{*}{ Coef. de var. (\%) } & & 35,30 & 47,29 & 13,90 & 28,63 & 14,40 & 6,20 \\
\hline & & \multicolumn{2}{|c|}{ Cu-FD. } & \multicolumn{2}{|c|}{$\mathrm{Cu}-\mathrm{FF}$. } & \multicolumn{2}{|c|}{ Cu-grão } \\
\hline & & teor & quant.abs & teor & quant.abs. & teor & quant.abs \\
\hline Blocos & 3 & 2,57 & 17,0 & 4,23 & 5.694 & 0,9433 & 19.370 \\
\hline Tratamentos & 3 & $235,62 * *$ & $1.750,8 * *$ & $216,32^{* *}$ & $467.867 * *$ & $0,7424^{*}$ & $22.609^{*}$ \\
\hline Resíduo & 9 & 1,66 & 22,3 & 1,82 & 2.122 & 0,1385 & 4.898 \\
\hline Total & 15 & & & & & & \\
\hline \multirow[t]{3}{*}{ Coef. de var. (\%) } & & 11,30 & 22,76 & 14,79 & 26,45 & 28,56 & 53,47 \\
\hline & & \multicolumn{2}{|c|}{ Cu-palha } & \multicolumn{2}{|c|}{ Cu-sabugo } & \multicolumn{2}{|c|}{ Mn-bainha } \\
\hline & & teor & quant.abs. & teor & quant.abs. & teor & quant.abs. \\
\hline Blocos & 3 & 0,02 & 0,0311 & 1,30 & 4.352 & 474 & 402.572 \\
\hline Tratamentos & 3 & $55,65^{* *}$ & $1,1886 * *$ & $18,63 * *$ & $3.474 \mathrm{~ns}$ & $19.124^{* *}$ & $9.218 .017^{* *}$ \\
\hline Resíduo & 9 & 0,39 & 0,0212 & 0,71 & 988 & 441 & 220.428 \\
\hline Total & 15 & & & & & & \\
\hline \multirow[t]{3}{*}{ Coef. de var. (\%) } & & 21,98 & 8,93 & 27,67 & 41,51 & 29,76 & 41,72 \\
\hline & & \multicolumn{2}{|c|}{ Mn-colmo } & \multicolumn{2}{|c|}{ Mn-FD. } & \multicolumn{2}{|c|}{ Mn-FF. } \\
\hline & & teor & quant.abs & teor & quant.abs. & teor & quant.abs. \\
\hline Blocos & 3 & 6,08 & 90.791 & 0,0026 & 737 & 161 & 1.159 .241 \\
\hline Tratamentos & 3 & $278,85^{* *}$ & $950.631 * *$ & $0,7303^{* *}$ & $28.356^{* *}$ & $30.576^{* *}$ & $59.134 .291^{* *}$ \\
\hline Resíduo & 9 & 12,91 & 46.537 & 0,0080 & 478 & 480 & 1.057 .094 \\
\hline Total & 15 & & & & & & \\
\hline Coef. de var. (\%) & & 23,63 & 39,19 & 4,56 & 28,46 & 26,54 & 36,89 \\
\hline
\end{tabular}

Coef. de var. = coeficiente de variação; FD. = folha diagnose; FF. = folhas ao final do ciclo da cultura; quant. abs. = quantidade absorvida.

* = Significativo, pelo teste $\mathrm{F}$, ao nivel de $5 \%(\alpha \leq 0,05)$.

** $=$ Significativo, pelo teste $\mathrm{F}$, ao nível de $1 \%(\alpha \leq 0,01)$.

$\mathrm{ns}=$ Não significativo. pelo teste $\mathrm{F}$, considerando-se como n.m.s. $5 \%(\alpha>0,05)$. 
Apêndice 4.4 Análise da variância e coeficiente de variação para as variáveis teores e quantidades de $\mathrm{Mn}$ no grão, na palha e no sabugo e teores e quantidades de $\mathrm{Zn}$ nas diversas partes da planta de milho.

\begin{tabular}{|c|c|c|c|c|c|c|c|}
\hline \multirow[t]{3}{*}{ Causas de Variação } & \multirow[t]{3}{*}{ G.L. } & \multicolumn{6}{|c|}{ Q.M. } \\
\hline & & \multicolumn{2}{|c|}{ Mn-grão } & \multicolumn{2}{|c|}{ Mn-palha } & \multicolumn{2}{|c|}{ Mn-sabugo } \\
\hline & & teor & quant.abs. & teor & quant.abs. & teor & quant.abs. \\
\hline Blocos & 3 & 0,6420 & 144.904 & 3,63 & 2.764 & 0,9526 & 8,4592 \\
\hline Tratamentos & 3 & $5,9525 \mathrm{~ns}$ & $112.169 \mathrm{~ns}$ & $303,89 * *$ & $136.397^{* *}$ & $75,5949 *$ & $18,400 \operatorname{lns}$ \\
\hline Resíduo & 9 & 3,0457 & 72.535 & 9,65 & 9.763 & 12,0289 & 6,6019 \\
\hline Total & 15 & & & & & & \\
\hline \multirow[t]{3}{*}{ Coef. de var. (\%) } & & 23,20 & 47,61 & 14,74 & 32,81 & 36,20 & 22,87 \\
\hline & & \multicolumn{2}{|c|}{ Zn-bainha } & \multicolumn{2}{|c|}{ Zn-colmo } & \multicolumn{2}{|c|}{$\mathrm{Zn}-\mathrm{FD}$} \\
\hline & & teor & quant.abs. & teor & quant.abs. & teor & quant.abs. \\
\hline Blocos & 3 & 0,0670 & 0,0616 & 0,0400 & 0,0409 & 0,0029 & 0,0006 \\
\hline Tratamentos & 3 & $1,8968^{* *}$ & $2,2716^{* *}$ & $2,0164^{* *}$ & $3,2791^{* *}$ & $0,4174 * *$ & $0,0293^{* *}$ \\
\hline Resíduo & 9 & 0,0225 & 0,0200 & 0,0151 & 0,0138 & 0,0086 & 0,0005 \\
\hline Total & 15 & & & & & & \\
\hline \multirow[t]{3}{*}{ Coef. de var. (\%) } & & 9,49 & 5,87 & 12,14 & 5.26 & 6,03 & 12,50 \\
\hline & & \multicolumn{2}{|c|}{$\mathrm{Zn}-\mathrm{FF}$} & \multicolumn{2}{|c|}{ Zn-grão } & \multicolumn{2}{|c|}{ Zn-palha } \\
\hline & & teor & quant.abs. & teor & quant.abs. & teor & quant.abs. \\
\hline Blocos & 3 & 117 & 605.016 & 35,29 & 3.844 .078 & 0,0037 & 0,0076 \\
\hline Tratamentos & 3 & $4.275^{* *}$ & $10.449 .846^{* *}$ & $609.57^{* *}$ & $16.484 .060^{* *}$ & $2,7336^{* *}$ & $3,4323 * *$ \\
\hline Resíduo & 9 & 46 & 199.460 & 34.69 & 1.587 .289 & 0,0106 & 0.0274 \\
\hline Total & 15 & & & & & & \\
\hline \multirow[t]{2}{*}{ Coef. de var. (\%) } & & 29,02 & 41,79 & 21.50 & 49,39 & 7,64 & 5,14 \\
\hline & & teor & $\begin{array}{l}\text { sabugo } \\
\text { quant.abs. }\end{array}$ & 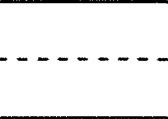 & & & \\
\hline Blocos & 3 & 713 & 366.257 & & & & \\
\hline Tratamentos & 3 & $29.729 * *$ & $7.689 .206^{* *}$ & & & & \\
\hline Resíduo & 9 & 359 & 285.996 & & & & \\
\hline Total & 15 & & & & & & \\
\hline Coef. de var. (\%) & & 57,68 & 68.35 & & & & \\
\hline
\end{tabular}

Coef. de var. = coeficiente de variação; $F D$. = folha diagnose: $F F .=$ folhas ao final do ciclo da cultura; quant. abs. = quantidade absorvida;

* = Significativo. pelo teste F. ao nível de $5 \%(\alpha \leq 0,05)$.

** = Significativo, pelo teste $\mathrm{F}$, ao nível de $1 \%(\alpha \leq 0,01)$. 
Apêndice 4.5 Desdobramento dos graus de liberdade de Tratamentos em contrastes ortogonais e teste $\mathrm{F}$ para as variáveis teores e quantidades absorvidas de $\mathrm{Cr}$ e $\mathrm{Cu}$ nas diversas partes da planta de milho e teores e quantidades de Mn na bainha, colmo, FD e FF.

\begin{tabular}{|c|c|c|c|c|c|c|c|}
\hline \multirow[t]{3}{*}{ Causas de Variação } & \multirow[t]{3}{*}{ G.L. } & \multicolumn{6}{|c|}{ Q.M. } \\
\hline & & \multicolumn{2}{|c|}{ Cr-sabugo } & \multicolumn{2}{|c|}{ Cu-bainha } & \multicolumn{2}{|c|}{ Cu-colmo } \\
\hline & & teor & quant.abs & teor & quant.abs. & teor & quant.abs \\
\hline Com lodo vs sem lodo & 1 & $0,3108 \mathrm{~ns}$ & $890 \mathrm{~ns}$ & $2,3862^{* *}$ & $134.845^{* *}$ & $1,6830^{* *}$ & $5,9345^{* *}$ \\
\hline Com lodo (LV vs LR) & 1 & $0,2178 \mathrm{~ns}$ & $35 \operatorname{lns}$ & $0,0165 \mathrm{~ns}$ & $77 \mathrm{~ns}$ & $0,0188 \mathrm{~ns}$ & $0,0638^{*}$ \\
\hline Sem lodo (LV vs LR) & 1 & $6,7161^{* *}$ & $2.230^{*}$ & $0,0784 * *$ & 819ns & $0,2224 * *$ & $0,2804 * *$ \\
\hline \multirow[t]{3}{*}{ Resíduo } & 9 & 0,3048 & 230 & 0,0052 & 710 & 0,0133 & 0,0097 \\
\hline & & \multicolumn{2}{|c|}{$\mathrm{Cu}-\mathrm{FD}$. } & \multicolumn{2}{|c|}{$\mathrm{Cu}-\mathrm{FF}$. } & \multicolumn{2}{|c|}{ Cu-grão } \\
\hline & & teor & quantabs & teor & quantabs & teor & quantabs \\
\hline Com lodo vs sem lodo & 1 & $449 * *$ & $4.367 * *$ & $425^{* *}$ & $1004598^{* *}$ & $1,9914 * *$ & $11.709 \mathrm{~ns}$ \\
\hline Com lodo (LV vs LR) & 1 & $1,7719 \mathrm{~ns}$ & $27 \mathrm{~ns}$ & $62 * *$ & $43.142 * *$ & $0,0079 \mathrm{~ns}$ & $54.278^{* *}$ \\
\hline Sem lodo (LV vs LR) & 1 & $255^{* *}$ & $856^{* *}$ & $162 * *$ & $355.860 * *$ & $0,0570 \mathrm{~ns}$ & 249ns \\
\hline \multirow[t]{3}{*}{ Resíduo } & 9 & 1,66 & 22,3 & 1,82 & 2.122 & 0,1385 & 4.898 \\
\hline & & \multicolumn{2}{|c|}{ Cu-palha } & \multicolumn{2}{|c|}{ Cu-sabugo } & \multicolumn{2}{|c|}{ Mn-bainha } \\
\hline & & teor & quant.abs. & teor & quant.abs. & teor & quant.abs. \\
\hline Com lodo vs sem lodo & 1 & $157^{* *}$ & $3,3814^{* *}$ & $39 * *$ & $3.528 \mathrm{~ns}$ & $35.419^{* *}$ & $16.570 .863^{* *}$ \\
\hline Com lodo (LV vs LR) & 1 & $0,0002 \mathrm{~ns}$ & $0,0006 \mathrm{~ns}$ & $0,5275 \mathrm{~ns}$ & $1.507 \mathrm{~ns}$ & $12.519^{* *}$ & $7.052 .716^{* *}$ \\
\hline Sem lodo (LV vs LR) & 1 & $10^{* *}$ & $0,1838 *$ & $14^{* *}$ & $4.611 \mathrm{~ns}$ & $9.434^{* *}$ & $4.030 .472 * *$ \\
\hline \multirow[t]{3}{*}{ Resíduo } & 9 & 0,39 & 0,0212 & 0,71 & 988 & 441 & 220.428 \\
\hline & & \multicolumn{2}{|c|}{ Mn-colmo } & \multicolumn{2}{|c|}{ Mn-FD. } & \multicolumn{2}{|c|}{$\mathrm{Mn}-\mathrm{FF}$. } \\
\hline & & teor & quant.abs & teor & quantabs. & teor & quantabs. \\
\hline Com lodo vs sem lodo & 1 & $529 * *$ & $603.620^{* *}$ & $0,0034 \mathrm{~ns}$ & $15.640^{* *}$ & $242 n s$ & $1.511 .729 \mathrm{~ns}$ \\
\hline Com lodo (LV vs LR) & 1 & $185^{* *}$ & $2.027 .751^{* *}$ & $1,6338 * *$ & $54.890^{* *}$ & $72.292 * *$ & $134.421 .622^{* *}$ \\
\hline Sem lodo (LV vs LR) & 1 & $123^{*}$ & $220.523 \mathrm{~ns}$ & $0,5538^{* *}$ & $14.538^{* *}$ & $19.196^{* *}$ & $41.469 .521^{* *}$ \\
\hline Resíduo & 9 & 12,91 & 46.537 & 0,0080 & 478 & 480 & 1.057 .094 \\
\hline
\end{tabular}

* = Significativo, pelo teste $\mathrm{F}$, ao nível de $5 \%(\alpha \leq 0,05)$.

$* *$ = Significativo, pelo teste $\mathrm{F}$, ao nível de $1 \%(\alpha \leq 0,01)$.

ns = Não significativo. pelo teste F, considerando-se como n.m.s. $5 \%(\alpha>0,05)$. 
Apêndice 4.6 Desdobramento dos graus de liberdade de Tratamentos em contrastes ortogonais e teste F para as variáveis teores e quantidades de Mn no grão, na palha e no sabugo e teores e quantidades de $\mathrm{Zn}$ nas diversas partes da planta de milho.

\begin{tabular}{|c|c|c|c|c|c|c|c|}
\hline \multirow[t]{3}{*}{ Causas de Variação } & \multirow[t]{3}{*}{$\overline{\mathrm{G} . \mathrm{L}}$} & \multicolumn{6}{|c|}{ Q.M. } \\
\hline & & \multicolumn{2}{|c|}{ Mn-grão } & \multicolumn{2}{|c|}{ Mn-palha } & \multicolumn{2}{|c|}{ Mn-sabugo } \\
\hline & & teor & quant.abs & teor & quant.abs. & teor & quant.abs \\
\hline Com lodo vs sem lodo & 1 & $0,1977 \mathrm{~ns}$ & $269 \mathrm{~ns}$ & $48 \mathrm{~ns}$ & $5.627 \mathrm{~ns}$ & $20 \mathrm{~ns}$ & $28,4591 \mathrm{~ns}$ \\
\hline Com lodo (LV vs LR) & 1 & $9,7760 \mathrm{~ns}$ & $358.498 \mathrm{~ns}$ & $601 * *$ & $356.803^{* *}$ & $182 * *$ & $25,4637 \mathrm{~ns}$ \\
\hline Sem lodo (LV vs LR) & 1 & $7,4498 \mathrm{~ns}$ & $1.100 \mathrm{~ns}$ & $263 * *$ & $46.760 \mathrm{~ns}$ & $25 \mathrm{~ns}$ & $1,2776 \mathrm{~ns}$ \\
\hline \multirow[t]{3}{*}{ Resíduo } & 9 & 3,0457 & 72.535 & 9,65 & 9.763 & 12,0289 & 6,6019 \\
\hline & & \multicolumn{2}{|c|}{ Zn-bainha } & \multicolumn{2}{|c|}{ Zn-colmo } & \multicolumn{2}{|c|}{$\mathrm{Zn}-\mathrm{FD}$. } \\
\hline & & teor & quant.abs & teor & quant.abs. & teor & quant.abs \\
\hline Com lodo vs sem lodo & 1 & $5,0194^{* *}$ & $5,8670^{* *}$ & $5,9414^{* *}$ & $9,5782^{* *}$ & $1,1722^{* *}$ & $0,0861^{* *}$ \\
\hline Com lodo (LV vs LR) & 1 & $0,0792 \mathrm{~ns}$ & $0,1342 *$ & $0,0406 \mathrm{~ns}$ & $0,0240 \mathrm{~ns}$ & $0,0415 \mathrm{~ns}$ & $0,0015 \mathrm{~ns}$ \\
\hline Sem lodo (LV vs LR) & 1 & $0,5918^{* *}$ & $0,8135^{* *}$ & $0,0672 \mathrm{~ns}$ & $0,2351^{* *}$ & $0,0384 \mathrm{~ns}$ & $0,0002 \mathrm{~ns}$ \\
\hline \multirow[t]{3}{*}{ Resíduo } & 9 & 0,0225 & 0,0200 & 0,0151 & 0,0138 & 0,0086 & 0,0005 \\
\hline & & \multicolumn{2}{|c|}{ Zn-FF. } & \multicolumn{2}{|c|}{ Zn-grão } & \multicolumn{2}{|c|}{ Zn-palha } \\
\hline & & teor & quant.abs. & teor & quant.abs. & teor & quant.abs. \\
\hline Com lodo vs sem lodo & 1 & $12.728^{* *}$ & $30.476 .196^{* *}$ & $1.229^{* *}$ & $11381568^{*}$ & $7,6892 * *$ & $9,4589^{* *}$ \\
\hline Com lodo (LV vs LR) & 1 & $78 \mathrm{~ns}$ & $859.020 \mathrm{~ns}$ & $421^{* *}$ & $35718532^{* *}$ & $0,1202 * *$ & $0,1373 n s$ \\
\hline Sem lodo (LV vs LR) & 1 & $17 \mathrm{~ns}$ & $14.324 \mathrm{~ns}$ & $152 \mathrm{~ns}$ & $2734034 n s$ & $0,3913 * *$ & $0,7007 * *$ \\
\hline \multirow[t]{3}{*}{ Resíduo } & 9 & 46 & 199.460 & 35 & 1.587 .289 & 0,0106 & 0,0274 \\
\hline & & \multicolumn{2}{|c|}{ Zn-sabugo } & & & & \\
\hline & & teor & quantabs & & & & \\
\hline Com lodo vs sem lodo & 1 & $88.601^{* *}$ & $22.123 .571^{* *}$ & & & & \\
\hline Com lodo (LV vs LR) & 1 & 534ns & $837.344 \mathrm{~ns}$ & & & & \\
\hline Sem lodo (LV vs LR) & 1 & $54 \mathrm{~ns}$ & $106.702 \mathrm{~ns}$ & & & & \\
\hline Resíduo & 9 & 359 & 285.996 & & & & \\
\hline
\end{tabular}

* = Significativo, pelo teste $\mathrm{F}$, ao nível de $5 \%(\alpha \leq 0,05)$.

** = Significativo, pelo teste F. ao nível de $1 \%(\alpha \leq 0,01)$.

ns = Não significativo. pelo teste F, considerando-se como n.m.s. $5 \%(\alpha>0,05)$. 
Apêndice 4.7 Análise da variância e coeficiente de variação para as variáveis produtividade, matéria seca total e teores e quantidades totais absorvidas de $\mathrm{N}$ na FD e na FF.

\begin{tabular}{|c|c|c|c|c|c|}
\hline \multirow[t]{3}{*}{ Causas de Variação } & \multirow[t]{3}{*}{ G.L. } & \multicolumn{4}{|c|}{ Q.M. } \\
\hline & & \multirow[b]{2}{*}{ Produtividade } & \multirow[b]{2}{*}{ MS-total } & \multicolumn{2}{|c|}{ N-FD. } \\
\hline & & & & teor & quant.abs \\
\hline Blocos & 3 & $1.135 .006,33$ & 871,93 & 35,6828 & 0,0002 \\
\hline Tratamentos & 3 & $2.399 .464,83^{* *}$ & $15.592,86^{* *}$ & $176,9202 * *$ & $0,0038 * *$ \\
\hline Resíduo & 9 & 326.463 .94 & 920,56 & 9,1996 & 0,0001 \\
\hline Total & 15 & & & & \\
\hline \multirow[t]{3}{*}{ Coef. de variação (\%) } & & 14,46 & 20,00 & 8,02 & 21,27 \\
\hline & & \multicolumn{2}{|c|}{ N-FF. } & & \\
\hline & & teor & quant.abs & & \\
\hline Blocos & 3 & 1,4294 & 0,0222 & & \\
\hline Tratamentos & 3 & $181,8768^{* *}$ & $0,4263^{* *}$ & & \\
\hline Residuo & 9 & 2,2984 & 0,0089 & & \\
\hline Total & 15 & & & & \\
\hline Coef. de variação (\%) & & 9,07 & 22,11 & & \\
\hline
\end{tabular}

FD. = folha diagnose: $\mathrm{FF}$. = folhas ao final do ciclo da cultura; quant.abs. = quantidade absorvida. ** = Significativo, pelo teste $F$, ao nivel de $1 \%(\alpha \leq 0,01)$. 
Apêndice 4.8 Desdobramento dos graus de liberdade de Tratamentos em contrastes ortogonais e teste $\mathrm{F}$ para as variáveis produtividade, matéria seca total e teores e quantidades totais absorvidas de $\mathrm{N}$ na FD e na FF.

\begin{tabular}{|c|c|c|c|c|c|}
\hline \multirow[t]{3}{*}{ Causas de Variação } & \multirow[t]{3}{*}{ G.L. } & \multicolumn{4}{|c|}{ Q.M. } \\
\hline & & \multirow[b]{2}{*}{ Produtividade } & \multirow[b]{2}{*}{ MS-total } & \multicolumn{2}{|c|}{ N-FD. } \\
\hline & & & & teor & quant.abs \\
\hline Com lodo vs sem lodo & 1 & $1.178 .310 \mathrm{~ns}$ & $20,32^{* *}$ & $51,07 * *$ & $127,69 * *$ \\
\hline Com lodo (LV vs LR) & 1 & $5.822 .578^{* *}$ & $28,41^{* *}$ & $1,72 \mathrm{~ns}$ & $0,76 \mathrm{~ns}$ \\
\hline Sem lodo (LV vs LR) & 1 & $197.506 \mathrm{~ns}$ & $4,60 \mathrm{~ns}$ & $4,91 \mathrm{~ns}$ & $5,58 \mathrm{~ns}$ \\
\hline \multirow[t]{3}{*}{ Resíduo } & 9 & 326.463 & 920,56 & 9,20 & 0,0001 \\
\hline & & \multicolumn{2}{|c|}{ N-FF. } & & \\
\hline & & teor & quant.abs & & \\
\hline Com lodo vs sem lodo & 1 & $177,31^{* *}$ & $122,49^{* *}$ & & \\
\hline Com lodo (LV vs LR) & 1 & $37,56^{* *}$ & $5,86^{*}$ & & \\
\hline Sem lodo (LV vs LR) & 1 & $22,52 * *$ & $15,09 * *$ & & \\
\hline Resíduo & 9 & 2,30 & 0,0089 & & \\
\hline
\end{tabular}

FD. = folha diagnose FF. $=$ folhas ao final do ciclo da cultura: quant.abs. = quantidade absorvida.

* = Significativo, pelo teste $\mathrm{F}$, ao nível de $5 \%(\alpha \leq 0,05)$.

** = Significativo, pelo teste $F$, ao nível de $1 \%(\alpha \leq 0,01)$.

ns = Não significativo, pelo teste $F$, considerando-se como n.m.s $5 \%(\alpha>0,05)$. 
Apêndice 4.9 Análise da variância e coeficiente de variação para as variáveis diâmetro do colmo e altura.

\begin{tabular}{lccc}
\hline \multicolumn{1}{c}{ Causas de Variação } & G.L. & \multicolumn{2}{c}{ Q.M. } \\
\hline & 3 & 0,34 & Diâmetro do colmo \\
\cline { 2 - 4 } Blocos & 3 & $3,19^{*}$ & 3,1300 \\
Tratamentos & 9 & 0,71 & $36,6078 \mathrm{~ns}$ \\
Resíduo (A) & $(15)$ & & 9,7360 \\
\hdashline (Parcelas) & 11 & $38,69^{* *}$ & $1.189,9760^{* *}$ \\
Épocas & 33 & $1,61^{* *}$ & $4,1647^{* *}$ \\
Tratamentos x Épocas & 132 & 0,05 & 0,3550 \\
Resíduo (B) & 191 & & 10,12 \\
\hline Total & & 5,22 & 6,47 \\
\hline Coef. de var. (A) (\%) & & 6,90 & \\
Coef. de var. (B) (\%) & & & \\
\hline
\end{tabular}

* = Significativo, pelo teste $\mathrm{F}$, ao nível de $5 \%(\alpha \leq 0,05)$.

$* *$ = Significativo, pelo teste $\mathrm{F}$, ao nível de $1 \%(\alpha \leq 0,01)$.

ns = Não significativo, pelo teste F, considerando-se como n.m.s. $5 \%(\alpha>0,05)$.

Apêndice 5.0. Desdobramento dos graus de liberdade de Tratamentos em contrastes ortogonais para as variáveis diâmetro do colmo e altura.

\begin{tabular}{lccc}
\hline & & \multicolumn{2}{c}{ Q.M. } \\
\cline { 3 - 4 } \multicolumn{1}{c}{ Causas da Variação } & G.L. & diâmetro do colmo & altura \\
\hline Com lodo vs sem lodo & 1 & $4,96^{*}$ & $68,3090^{*}$ \\
Com lodo (LV vs LR) & 1 & $3,37 \mathrm{~ns}$ & $0,3009 \mathrm{~ns}$ \\
Sem lodo (LV vs LR) & 1 & $1,20 \mathrm{~ns}$ & $30,8004 \mathrm{~ns}$ \\
Residuo & 9 & 0,71 & 9,7360 \\
\hline
\end{tabular}

$*=$ Significativo, pelo teste $F$, ao nível de $5 \%(\alpha \leq 0,05)$.

ns $=$ Não significativo, pelo teste $F$, considerando-se como n.m.s $5 \%(\alpha>0,05)$. 